\title{
The use of the palladium-catalyzed glycosylation for the synthesis of C- and O-linked glycosylated natural products
}

Xiaomei Yu

West Virginia University

Follow this and additional works at: https://researchrepository.wvu.edu/etd

\section{Recommended Citation}

$\mathrm{Yu}, \mathrm{Xiaomei}$, "The use of the palladium-catalyzed glycosylation for the synthesis of C- and O-linked glycosylated natural products" (2010). Graduate Theses, Dissertations, and Problem Reports. 3096. https://researchrepository.wvu.edu/etd/3096

This Dissertation is protected by copyright and/or related rights. It has been brought to you by the The Research Repository @ WVU with permission from the rights-holder(s). You are free to use this Dissertation in any way that is permitted by the copyright and related rights legislation that applies to your use. For other uses you must obtain permission from the rights-holder(s) directly, unless additional rights are indicated by a Creative Commons license in the record and/ or on the work itself. This Dissertation has been accepted for inclusion in WVU Graduate Theses, Dissertations, and Problem Reports collection by an authorized administrator of The Research Repository @ WVU.

For more information, please contact researchrepository@mail.wvu.edu. 


\title{
The Use of the Palladium-catalyzed Glycosylation for the Synthesis of $C$ - and $O$-linked Glycosylated Natural Products
}

\author{
Xiaomei Yu
}

Dissertation submitted to the Eberly College of Arts and Sciences at West Virginia University in partial fulfillment of the requirements for the degree of

\author{
Doctor of Philosophy \\ In \\ Organic Chemistry
}

\author{
Kung K. Wang, Ph.D., Chair \\ John H. Penn, Ph.D. \\ Yon Rojanasakul, Ph.D. \\ Björn C. G. Söderberg, Ph.D. \\ Xiaodong Shi, Ph.D. \\ C. Eugene Bennett Department of Chemistry \\ Morgantown, West Virginia \\ 2010
}

Keywords: Glycosylation, PI-080, Campothecin, Ellipticine

Copyright 2010 Xiaomei Yu 


\section{ABSTRACT \\ The Use of the Palladium-catalyzed Glycosylation for the Synthesis of $C$ - and $O$-linked Glycosylated Natural Products}

\section{Xiaomei Yu}

The carbohydrate portions of natural products play a crucial role in their pharmacological properties. These properties can vary from improved water solubility, improved membrane transport properties, improved tissue targeting, as well as improved target binding. Herein we describe our efforts to use de novo synthesis to help elucidate the various roles carbohydrates play in biologically active glycosylated natural products.

The O’Doherty group has developed a method that uses asymmetric synthesis for the de novo synthesis of carbohydrates. In contrast to traditional carbohydrate methods, this de novo approach builds the desired functionality and stereochemistry within each sugar. This methodology relies on a highly diastereoselective palladium(0)catalyzed glycosylation reaction to control the stereochemistry at the anomeric center and post-glycosylation transformation to introduce the corresponding functionality in the sugar moiety.

This de novo approach was first used in a highly enantio- and diastereoselective synthesis of Vineomycin C and PI-080. The trisaccharide was made up of three rare sugars, an $\alpha$-L-aculose, an $\alpha$-L-rhodinose and a $\beta$-D-olivose. The key transformations 
include: the palladium-catalyzed glycosylation, Myers’ reductive rearrangement, diastereoselective dihydroxylation, and regioselective Mitsunobu inversion. Material from this synthetic effort was used in several biological studies, such as 60-cell line cytotoxicity screens and apoptosis/necrosis mechanism of cell death studies. Significant apoptotic antitumor activity was found for this trisaccharide, which has implication for Vineomycin C and PI-080's structure-activity relationship. To further elucidate the structural activity relationship for this trissacharide, we also prepared the enantiomeric $\mathrm{D} / \mathrm{D} / \mathrm{L}$-trisaccharide, which is made up of $\alpha$-D-aculose, $\alpha$-D-rhodinose and $\beta$-L-olivose sugars.

To further study the structure activity relationship of these $C$-aryl glycoside natural products, an effort was undertaken to develop a selective method for the installation of a $\beta$-C-aryl glycoside bond to an intact di- and tri-sacchardes. This began with a de novo synthesis of the disaccharide portion of two new $C$-aryl glycoside natural products, SCH-47554 and SCH-47555. Unfortunately, despite the exhaustive screening of Lewis acid, no method was found for the formation of the desired $\beta$ - $C$-aryl glycoside bond that did not occur with hydrolysis of the di- and tri-saccharide glycosidic bonds.

In the final chapter, an effort was described that was aimed at the synthesis of hydroxyl-substituted analogues of two biologically important natural products for further glycosylation. The two natural products that were chosen for these studies were the poly-aromatic alkaloids ellipticine and camptothecin. This effort was aimed at trying to improve the water solubility/membrane transport properties of these anticancer 
natural products. While the efforts to prepare the required hydroxy-substituted azaellipticin failed, a glycosylated camptothecin was prepared. Unfortunately, the acid sestivity of the glycosylated camptothecin limits its use in biological studies. 


\section{DEDICATED TO}

My husband, George O’Doherty and my parents, Guohui Yu, Mingying Liu 


\section{ACKNOWLEDGEMENTS}

I would like to express my sincere appreciation to my research advisor, Dr. Wang, for his valuable guidance, constant encouragement, and constructive comments throughout the course of this research. I have greatly benefited from his extensive knowledge and insight of chemistry, inspirational personality, and great enthusiasm in chemistry.

I also want to express my gratitude to my research committee members, Dr. John Penn, Dr. Yon Rojanasakul, Dr. Björn Söderberg, Dr. Xiaodong Shi, for their helpful suggestions and valuable discussions.

I thank the members of the Wang and O'Doherty group whom I've had the pleasure of working with, for all of the assistance they have given me in the last five years.

I would like to thank my parents, my wife, for being a source of love, inspiration, and support for me through the years. They, along with the rest of my family have believed in me from the beginning. I cannot imagine how I can reach this point without their support.

Financial supports from the C. Eugene Bennett department of chemistry at West Virginia University, the National Institutes of Health and the National Science Foundation are also gratefully acknowledged. 


\section{TABLE OF CONTENTS}

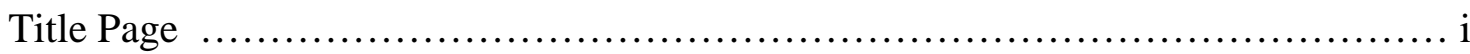

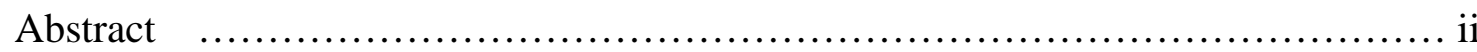

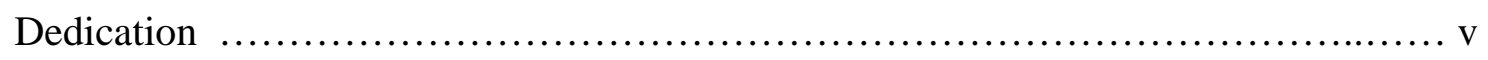

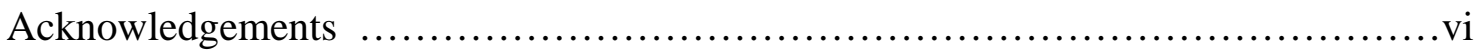

Table of Contents ............................................................vii

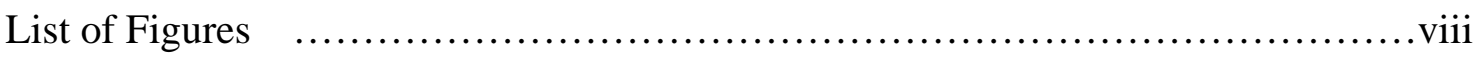

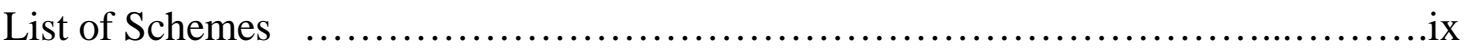

List of Tables .................................................................

List of Abbreviations .......................................................

Chapter I. De Novo Asymmetric Syntheses of the carbonhydrate portion of PI080 and Vineomycin C and its Enantiomer............................................

Chapter II. Application of De Novo Synthesis towards the Synthesis of C-Aryl

Glycoside Natural Products ............................................28

Chapter III. Attempted Synthesis of Glycosylated Poly-aromatic Natural Products via the Synthesis and Study of Hydrixy-substituted Poly-aromatic Natural Products ....... 38

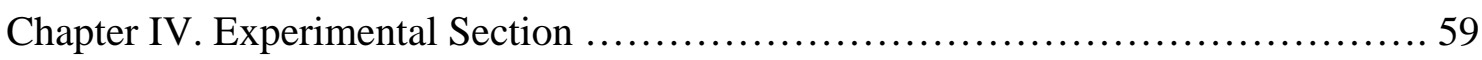

References and Notes...................................................134

Appendix: Spectra Graphs 


\section{List of Figures}

Figure 1: The angucycline/vineomycin aglycones .............................

Figure 2: The angucycline/vineomycin monosaccharides.......................2

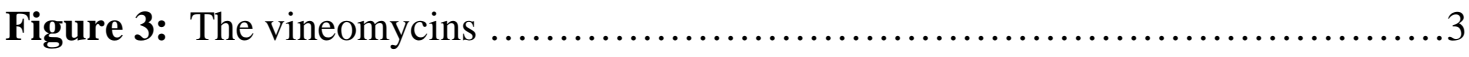

Figure 4: Other glycosylated angucycline antibiotics ..........................4

Figure 5: Structures of PI-080 and vineomycin C ..............................

Figure 6: Proof of the regioselective glycosylation by NMR structural assignment of

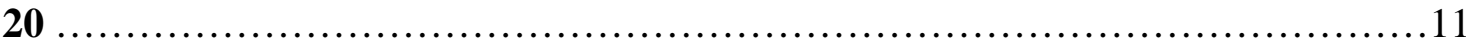

Figure 7: Cytotoxicity of 19/Cisplatin towards $H 460$.........................22

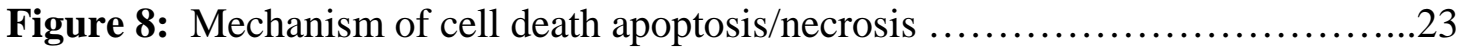

Figure 9: The (D,D,L)-trisaccharide 19 and the (L,L,D)-trisaccharide ent-19 .......24

Figure 10: Ellipticine and related compounds ..............................38

Figure 11: Ellipticine and related compounds ...............................39

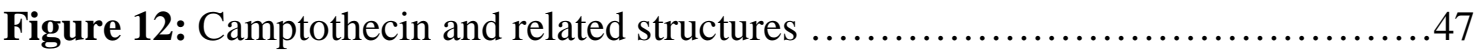




\section{List of Schemes}

Scheme 1: Hydrolytic conversion of angucycline to the vineomycin ring systems ....2

Scheme 2. Structures of PI-080 and vineomycin C and their trisaccharide motifs 3 and

4

Scheme 3: Retrosynthetic analysis of the vineomycin $C$ trisaccharide .7

Scheme 4: De novo approach to D/L-, $\alpha / \beta$-Boc-pyranones 5 and $6 \ldots \ldots \ldots \ldots \ldots \ldots . . .7$

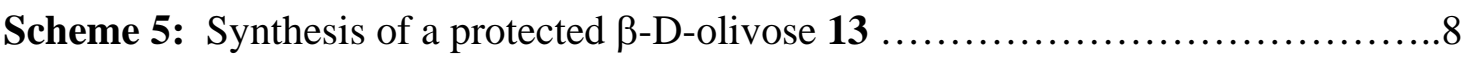

Scheme 6: Synthesis of a $\beta$-D-olivose/ $\alpha$-L-rhodinose disaccharide $17 \ldots \ldots \ldots \ldots \ldots . . . . .9$

Scheme 7: Synthesis of the vineomycin C/PI-080 trisaccharide 19 .................10

Scheme 8: Retrosynthesis the enantiomer of trisaccharide ent-19 .................24

Scheme 9: Retrosynthesis the enantiomer of monosaccharide ent-13 $\ldots \ldots \ldots \ldots \ldots . .25$

Scheme 10: Retrosynthesis the enantiomer of D,L-disaccharide ent-18 ............26

Scheme 11: Retrosynthesis the enantiomer of trisaccharide ent-19 ................27

Scheme 12: Retrosynthetic analysis for vineomycin $C$.........................28

Scheme 13: Retrosynthetic analysis for vineomycin $C$........................29

Scheme 14: Retrosynthetic analysis for PI-080 .............................30

Scheme 15: Retrosynthetic analysis for SCH-47554 and SCH-7555 ................31

Scheme 16: Synthesis of key Bromoanthracene coupling partner ...................31

Scheme 17: Synthesis of the D-amiceto-sugar of the desired disaccharide 38 .......32

Scheme 18: Synthesis of the D,L-disaccharides 38 and 39 ......................33

Scheme 19: Attempted Lewis coupling of 38 and 39 with $33 \ldots \ldots \ldots \ldots \ldots \ldots \ldots . . . .34$ 
Scheme 20: Synthesis of the vineomycin C/PI-080 trisaccharide $\mathbf{4 3}$ coupling partner 35

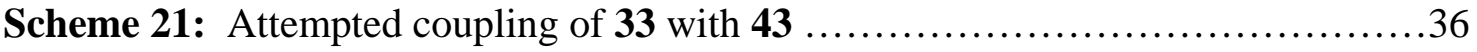

Scheme 22: The Wang cyclization approach to ellipticine .........................40

Scheme 23: Hydroxylated 5-aza-ellipticines for potential glycosylation ............41

Scheme 24: Retrosynthesis for a Hydroxylated aza-ellipticines .....................42

Scheme 25: Synthesis of the key alkynyl acid .................................43

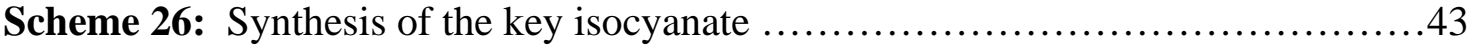

Scheme 27: Synthesis of a Hydroxylated aza-ellipticines .........................44

Scheme 28: Attempted deprotection of the benzyl ether ….......................45

Scheme 29: Synthesis of a Hydroxylated aza-ellipticines ..........................45

Scheme 30: Synthesis of a Hydroxylated aza-ellipticines ..........................46

Scheme 31: The Wang approach to camptothecin ................................49

Scheme 32: Attempted glycosylation of the tertiary hydroxyl of Camptothecin ......50

Scheme 33: Attempted glycosylation of the phenolic $\mathrm{OH}$ of SN-38 .................51

Scheme 34: Attempted synthesis of 11-substituted Camptothecin for Sonogashira

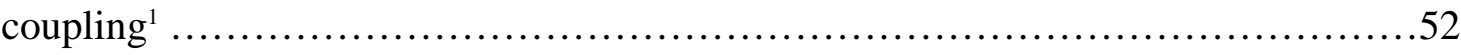

Scheme 35: Attempted synthesis of glycosylated Camptothecin via Sonogashira

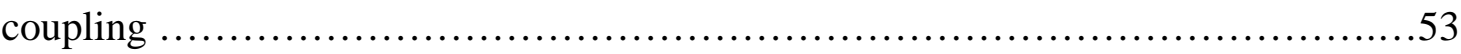

Scheme 36: Attempted synthesis of glycosylated Camptothecin via Sonogashira

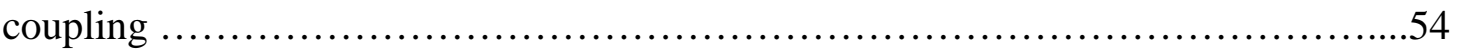

Scheme 37: Synthesis of a more soluble analogue of SN-38 .....................55 
Scheme 38: Successful synthesis of a glycosylated Camptothecin SN-38

Scheme 39: Reason for potential instability of glycosylated SN-38 .............57

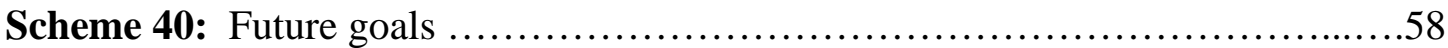




\section{List of Tables}

Table 1: Comparitive cytotoxicity evaluation of trisaccharide 19 ................12

Table 2: Leukemia cell cytotoxicity evaluation of trisaccharide 19 ...............13

Table 3: NSCL cancer cell cytotoxicity evaluation of trisaccharide 19 ..............14

Table 4: Colon Cancer cell cytotoxicity evaluation of trisaccharide 19 ...............15

Table 5: CNS Cancer cell cytotoxicity evaluation of trisaccharide 19 ...............16

Table 6: Melanoma Cancer cell cytotoxicity evaluation of trisaccharide 19 ..........17

Table 7: Ovarian Cancer cell cytotoxicity evaluation of trisaccharide 19 .............18

Table 8: Renal Cancer cell cytotoxicity evaluation of trisaccharide 19 ..............19

Table 9: Prostate Cancer cell cytotoxicity evaluation of trisaccharide 19 ............20

Table 10: Breast Cancer cell cytotoxicity evaluation of trisaccharide 19 ............21 


\section{List of Abbreviations}

\begin{tabular}{|c|c|c|c|}
\hline Ac & acetyl & & -phino)butane \\
\hline Anal. & Analysis & $\mathrm{dr}$ & diastereomeric ratio \\
\hline $\mathrm{Bn}$ & benzyl & ee & enantiomeric excess \\
\hline Boc & tert-Butyloxycarbonyl & EI & electron impact \\
\hline bp & boiling point & ent & enantiomer \\
\hline $\mathrm{Bz}$ & benzoyl & equiv & equivalent(s) \\
\hline calc & calculated & ESI & electrospray ionization \\
\hline CI & chemical ionization & Et & ethyl \\
\hline$\delta$ & chemical shift (ppm) & EtOAc & ethyl acetate \\
\hline $\mathrm{d}$ & doublet & $\mathrm{Et}_{2} \mathrm{O}$ & diethyl ether \\
\hline dba & dibenzylidene acetone & g & $\operatorname{gram}(\mathrm{s})$ \\
\hline DEAD & diethyl azodicarboxylate & h & hour(s) \\
\hline \multirow[t]{2}{*}{ DIAD } & diisopropyl & Hex & hexanes \\
\hline & azodicarboxylate & HMDS & hexamethyldisilane \\
\hline Dibal-H & $\begin{array}{l}\text { diisobutylaluminium } \\
\text { hydride }\end{array}$ & HPLC & $\begin{array}{l}\text { high pressure liquid } \\
\text { chromatography }\end{array}$ \\
\hline \multirow[t]{2}{*}{ DMAP } & 4-(dimethylamino) & $\mathrm{Hz}$ & hertz (cycles per second) \\
\hline & pyridine & IR & infrared \\
\hline DMF & dimethylformamide & $J$ & spin-spin coupling \\
\hline dppb & 1,4-bis(diphenylphos & & constant \\
\hline
\end{tabular}




\begin{tabular}{|c|c|c|c|}
\hline L-selectride & lithium tri-sec- & $\mathrm{R}_{f}$ & ratio to frontrt \\
\hline & butylborohydride & & room temperature \\
\hline Me & methyl & $\mathrm{t}$ & triplet \\
\hline $\mathrm{MHz}$ & megahertz & TBAF & tetrabutylammonium \\
\hline $\min$ & minute(s) & & fluoride \\
\hline mol & mole(s) & TBS & t-butyldimethylsilyl \\
\hline mmol & millimole(s) & $\mathrm{THF}$ & tetrahydrofuran \\
\hline $\mathrm{mp}$ & melting point & TLC & thin layer \\
\hline NBS & $N$-Bromosuccinimide & & chromatography \\
\hline NBSH & o-nitrobenzene & TMS & trimethylsilyl \\
\hline & sulfonylhydrazide & $\mathrm{T}_{\mathrm{f}}$ & trifluoromethanesulfonyl \\
\hline NMR & nuclear magnetic & $p$-TsOH & para-toluenesulfonic \\
\hline & resonance & & acid \\
\hline NMO & $\begin{array}{l}N \text {-methylmorpholine- } N \text { - } \\
\text {-oxide }\end{array}$ & & \\
\hline $\mathrm{Ph}$ & phenyl & & \\
\hline PMB & para-methoxybenzyl & & \\
\hline PNBz & para-nitrobenzoyl & & \\
\hline PABz & para-aminobenzoyl & & \\
\hline ppm & parts per million & & \\
\hline py & pyridine & & \\
\hline q & quartet & & \\
\hline
\end{tabular}




\section{Chapter I. De Novo Asymmetric Syntheses of the Carbohydrate Portion of PI080 and Vineomycin $C$ and its Enantiomer ${ }^{* 1}$}

Two of the more structurally interesting classes of the anthracycline antibiotic are the angucycline and the vineomycins. ${ }^{2}$ Both families of antibiotics have been of particular interest to both the synthetic and biological communities due to their unique structures and potent antitumor and antibacterial activities. ${ }^{3}$ The structural diversity of these classes of natural products are typified by two different types of glycosylated aglycon ring systems. ${ }^{4}$ Examples of the angucycline aglycones are the natural products WP-3688-2 and SS-22BY, ${ }^{5}$ as well as the

urdamycinone aglycon (Figure 1). Of the angucycline aglycons, SS-22BY can be viewed as a dehydrated version of WP-3688-2 and both are oxidized forms of the urdamycinone aglycon. While it is also not an isolated natural product, the vineomycin aglycon is represented by the synthetic Vineomycinone $\mathrm{B}_{2}$ methyl ester aglycon. ${ }^{6}$ Both types of natural products share the anthraquinone ring system, with the angucycline ring systems having a D-ring annulated.

Figure 1: The angucycline/vineomycin aglycones

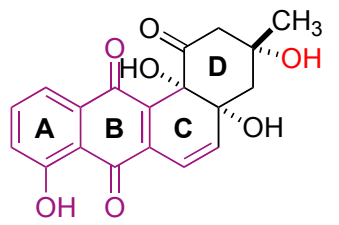

WP-3688-2

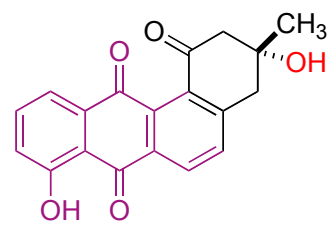

Urdamycinone aglycon

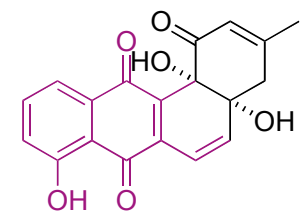

SS-22BY

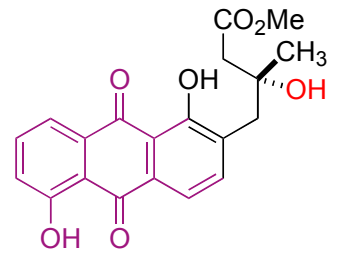

Vineomycinone $\mathrm{B}_{2}$ methyl ester aglycon

\footnotetext{
* Reproduced with permission from Org. Lett. 2008, 10, 4529-4532. Copyright 2008, American Chemical Society.
} 
The two types of angucycline/vineomycin aglycone ring systems can be related by a Dring hydrolysis/methanolysis. This is exemplified by the conversion of WP-3688-2 to give the Vineomycin $\mathrm{B}_{2}$ methyl ester aglycon, which is outlined in Scheme 1. Similarly, the three types of angucycline type of aglycons are related by an oxidative dihydroxylation of the Urdamycinone aglycon to form the WP-3688-2 ring system and a dehydration of WP-3688-2 to form the SS22BY ring system.

Scheme 1: Hydrolytic conversion of angucycline to the vineomycin ring systems

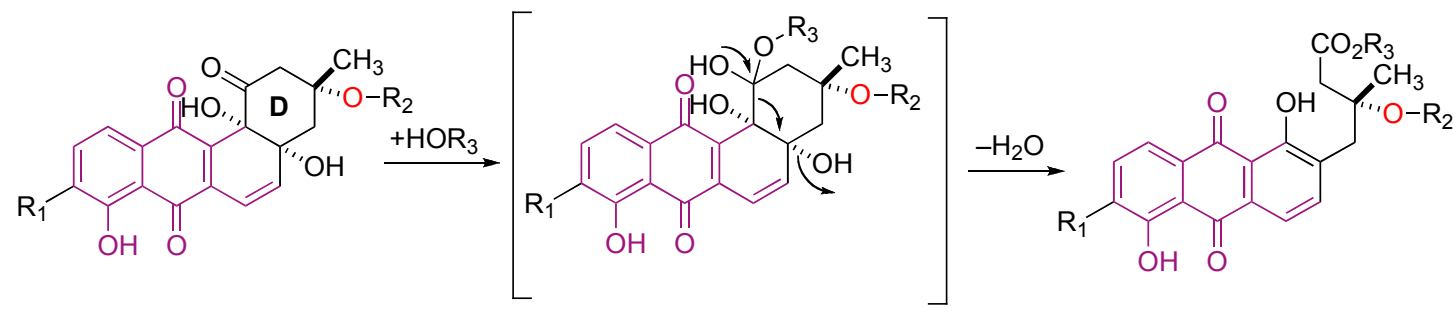

Most of the members of these two classes of natural products are glycosylated at the position ortho to the A-ring phenol ( $C-6$ for vinomycins and $C-9$ angucyclines). Examples of these monosaccaride $C$-glycosides are antibiotics Aquayamycin, ${ }^{7}$ Urdamycinone $\mathrm{B}^{8}$ and Vineomycinine $\mathrm{B}_{2}$ (Figure 2). ${ }^{9}$ In addition to having antibiotic properties, Aquayamycin is known to inhibit tyrosine hydroxylase and Vineomycin $\mathrm{B}_{2}$ has been shown to have antitumor activity. All three of these natural products have succumbed to total synthesis.

Figure 2: The angucycline/vineomycin monosaccharides

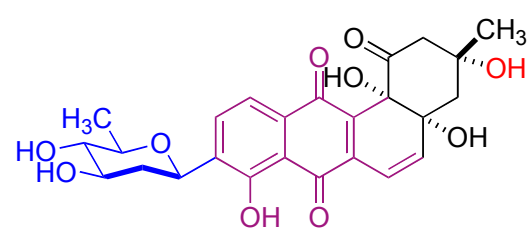

Aquayamycin

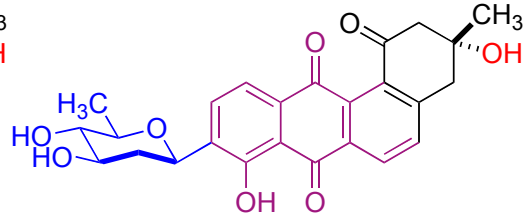

Urdamycinone B

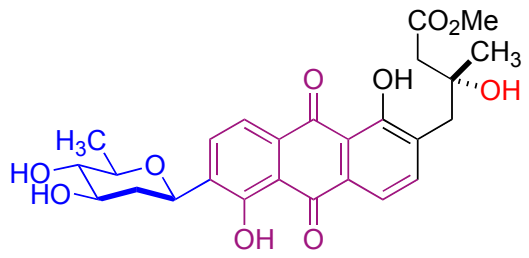

Vineomycinone $B_{2}$ methyl ester 
Outlined in Figure 3 is a list of the structures of the known vineomycin type antibiotics. It is interesting to note that Vineomycin $\mathrm{A}_{1}$ has the Urdamycinone ring system, which is consistant with the biosynthetic pathway that relates the two ring systmes (Scheme 1). This exception to the above classification probably resulted from the fact that the structures were named before the structures were elucidated. Hence the names that were chosen were based on the microbial species from which the natural products were isolated. With the exception of Vineomycin $A_{1}$, the various vineomycins vary in degrees of glycosylation, with mono-, di-, and tri-saccharides at the $C$-6 position via a $\beta$ - $C$-glycoside attachment and $\alpha$-linked $O$-glycosides on the side chain.

Figure 3: The vineomycins
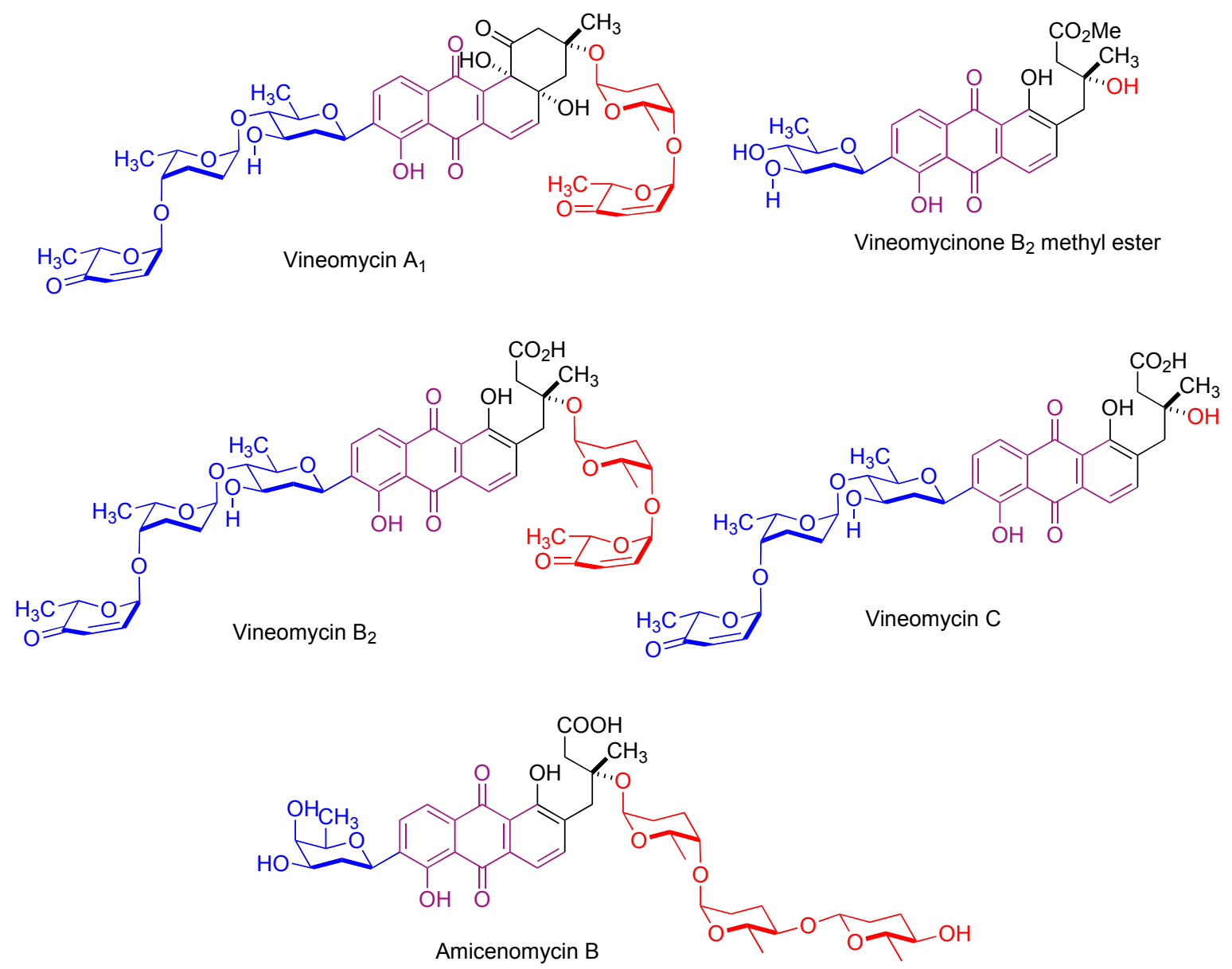
Like the vineomycins, the angucyclines consist of members with varying degrees of glycosylation. With mono-, di-, and trisaccharides at both the $C$-9 position (via a $\beta-C$-glycoside) and at the tertiary alcohol (via an $\alpha$ - $O$-glycoside).

Figure 4: Other glycosylated angucycline antibiotics
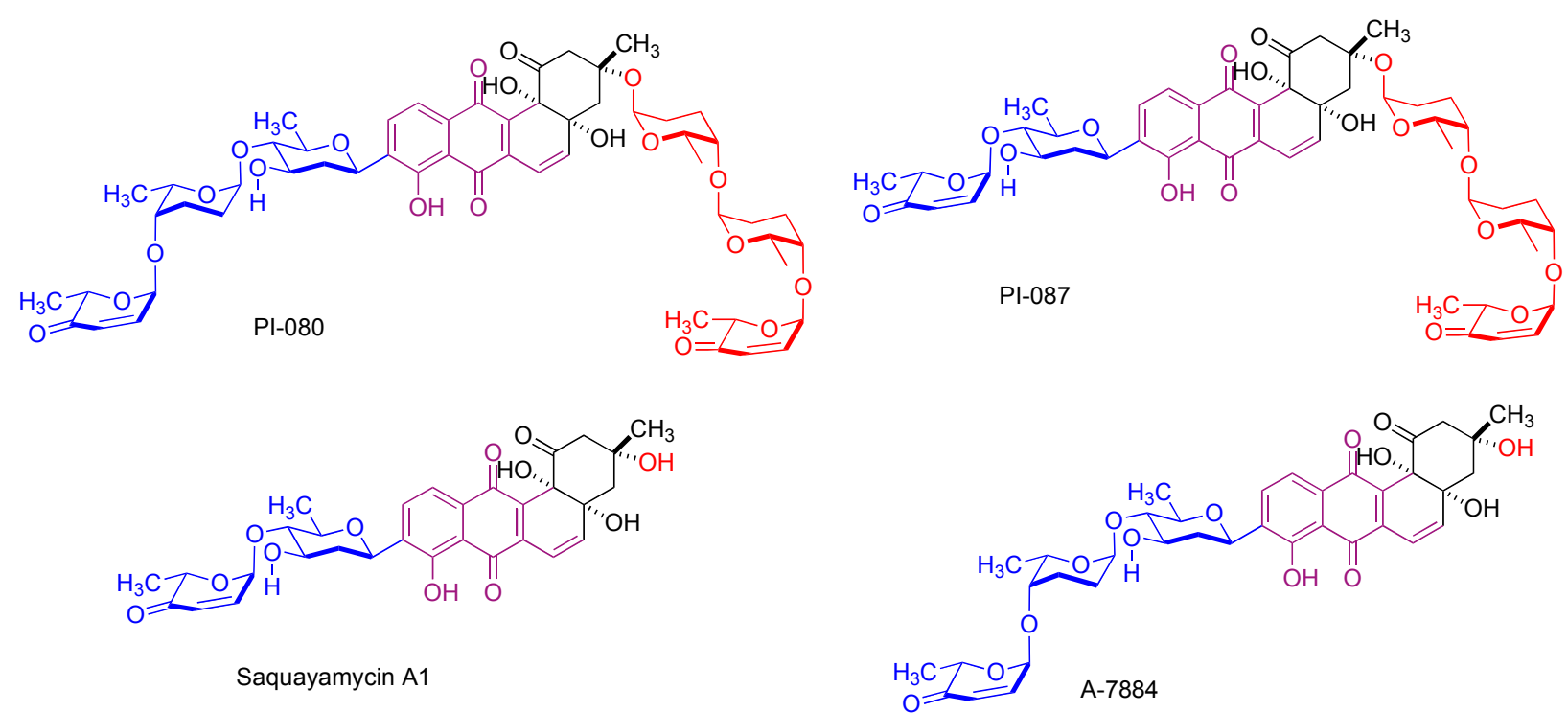

Of all these structural diverse $C$-glycoside natural products, the O'Doherty group became interested in PI-080 (1) ${ }^{10}$ and Vineomycin C (2). ${ }^{11}$ Both PI-080 ${ }^{12}$ and Vineomycin C share a $\beta$ $C$-glycoside link $\alpha$-L-aculose, $\alpha$-L-rhodinose (4), and $\beta$-D-olivose trisaccharide subunit, whereas PI-080 has an additional $\alpha$-L-aculose-bis- $\alpha$-L-rhodinose trisaccharide (3). In addition to representing a range of structures, the angucycline family of antibiotics possesses a range of biological activities. The antibiotic Vineomycin C displays potent antitumor activity, ${ }^{13}$ whereas PI-080 strongly inhibits blood coagulation. 
Figure 5: Structures of PI-080 and vineomycin C

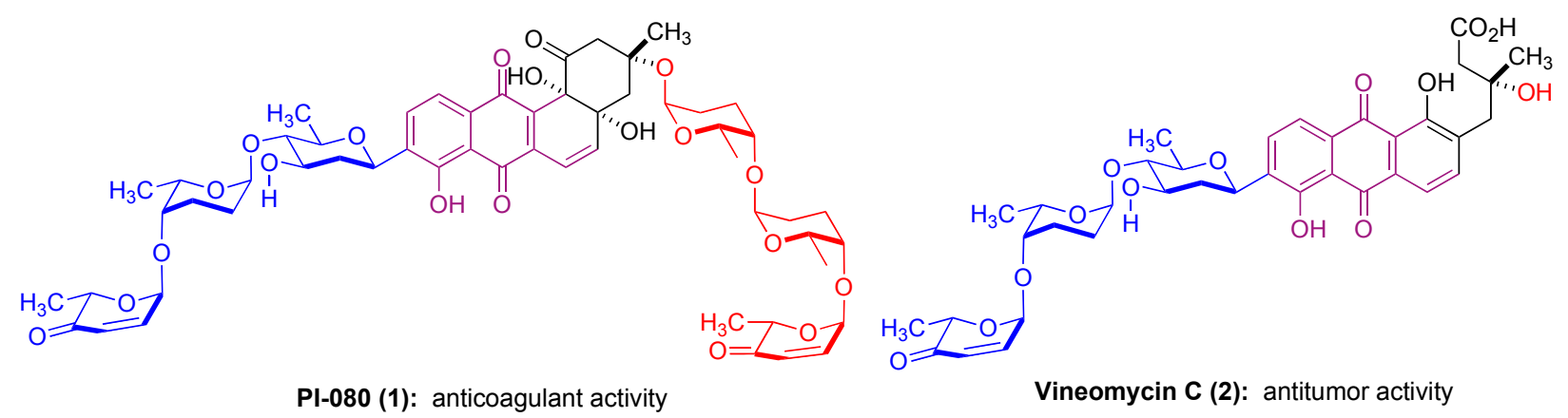

While the antitumor activity of the angucyclines has been attributed to the anthraquinone portion of natural products, ${ }^{13}$ the anticoagulant activity of PI-080 appears to be associated with one of the trisaccharide portions of the molecule (i.e., the trisaccharide 3). As part of a larger effort to use the de novo synthesis of carbohydrates for medicinal chemistry, the O'Doherty group became interested in elucidating the structural origins of the anticancer activity of Vineomycin C. In particular, we were interested in determining whether any of the antitumor activity associated with Vineomycin $\mathrm{C}$ could be attributed to the trisaccharide subunit 4 ( $\mathrm{R}=$ OPMB).

While there is no report of the total synthesis of PI-080 and Vineomycin B2, ${ }^{14}$ the synthesis of the trisaccharide portion 3 has been completed by Sulikowski. ${ }^{15}$ While the trisaccharide 3 could be obtained from natural sources, access to the trisaccharide subunit $4(\mathrm{R}=$ OPMB) required synthesis. Recently, the O'Doherty group had some success using a Pdcatalyzed glycosylation and post-glycosylation reactions for the synthesis of several naturally occurring rare sugar structural motifs. ${ }^{16}$ In this chapter, my efforts towards the de novo synthesis of trisaccharide subunit $\mathbf{4}$ from commercially available acylfuran will be described, along with its 
antiproliferative activity toward 60 tumor cells lines and apoptosis vs necrosis studies cell death mechanism studies.

Scheme 2. Structures of PI-080 and vineomycin C and their trisaccharide motifs 3 and 4

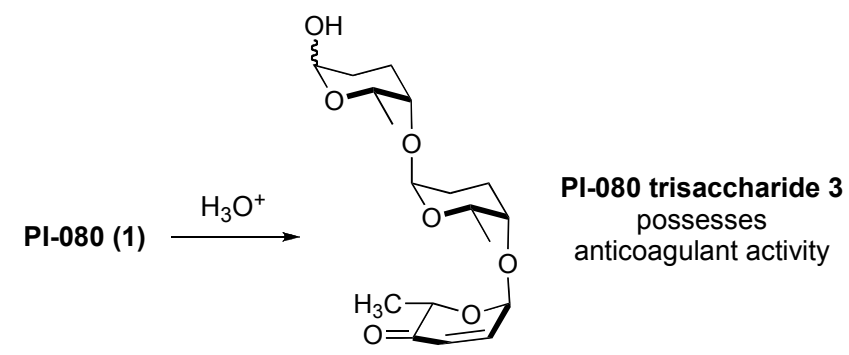

3

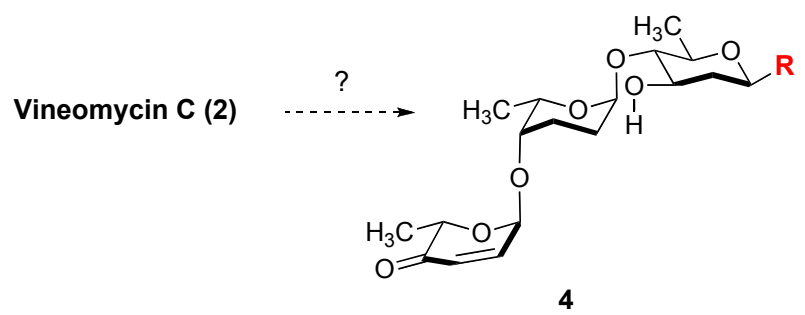

Retrosynthetically, it was envisioned that the $\alpha$-L-aculose and $\alpha$-L-rhodinose subunits of trisaccharide 4 would come from two $\alpha$-L-pyranones 5. Similarly, it was conceived the $\beta$-Dolivose ring of 4 would come from $\beta$-D-pyranone 6 (Scheme 3). Previously, it was shown in the O'Doherty group that the two pyranones could be prepared from the corresponding enantiomeric furyl alcohols, which in turn could be prepared by a Noyori reduction of 2-acylfuran 8 (Scheme 3)..$^{18,19}$ The 2-acylfuran is a rather inexpensive commodity chemical used in the food industry (from the Sigma-Aldrich at $\$ 0.07 / \mathrm{g}$ for a $10 \mathrm{Kg}$ scale). 
Scheme 3: Retrosynthetic analysis of the vineomycin C trisaccharide

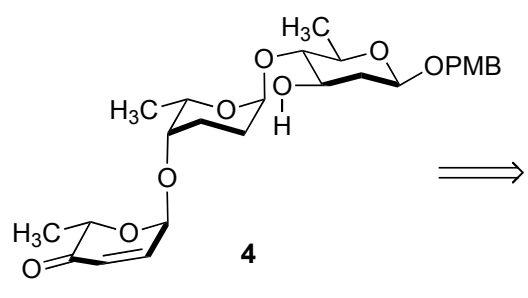

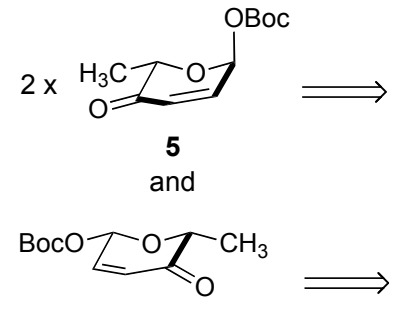

6
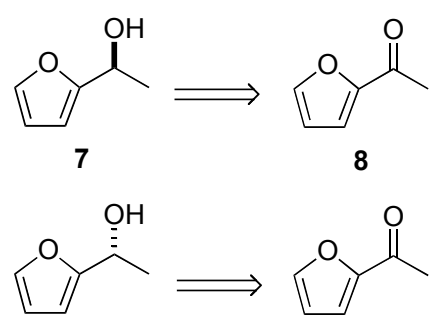

(ent)-7

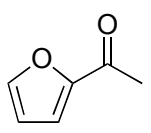

8

Previously, we have shown that the required Pd-glycosyl donors $\alpha$-L-pyranones 5 and $\beta$ D-pyranones 6, as well as their enantiomers, could be prepared from 2-acylfuran 8 (Scheme 4). The stereodivergent route employed an enantioselective Noyori reduction ( 8 to $7 /$ ent-7), ${ }^{17,18}$ an Achmatowicz oxidation and a diastereoselective $t$-butyl carbonate formation (Scheme 4). ${ }^{16,19}$ The $\beta$-pyranone 6 could be isolated in 50\% yield when the Boc-protection step was performed at elevated temperature $\left((\mathrm{Boc})_{2} \mathrm{O} / \mathrm{NaOAc}\right.$ in benzene at $\left.80{ }^{\circ} \mathrm{C}\right)$. Alternatively, $\alpha$-pyranone 5 could be selectively prepared in $62 \%(\alpha: \beta=3: 1)$ yield at low temperature $\left((\mathrm{Boc})_{2} \mathrm{O} / \mathrm{DMAP}\right.$ in $\mathrm{CH}_{2} \mathrm{Cl}_{2}$ at $\left.-78{ }^{\circ} \mathrm{C}\right)$.

Scheme 4: De novo approach to D/L-, $\alpha / \beta$-Boc-pyranones 5 and 6

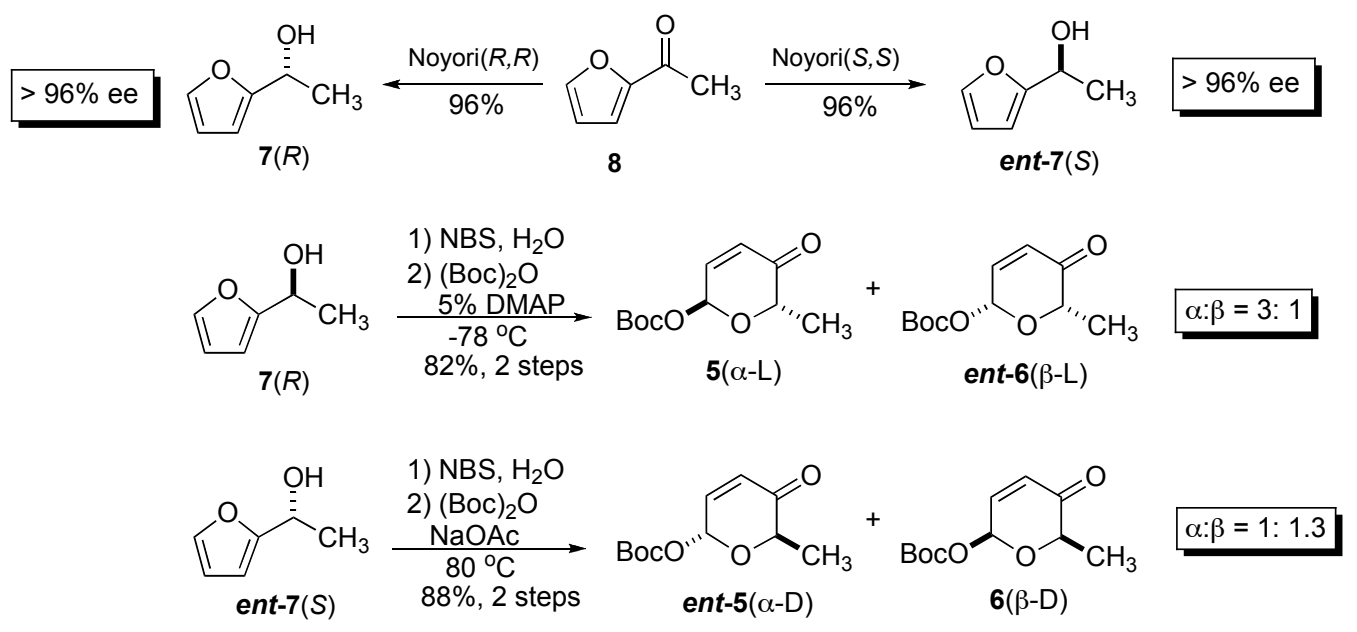


With a practical route to the desired pyranone glycosyl donors, we next turned our attention toward the preparation of 2-deoxy- $\beta$-L-olivose ring of the trisaccharide 4. Previously, we reported an approach to 2-deoxy- $\beta$-glycoside associated with allo- and glucostereochemistry. ${ }^{16,20}$ Key to the successful implementation of this strategy is the selective Mitsunobu-like inversion of the allo-stereochemistry of the digitoxose sugar $\mathbf{1 2}$ into olivose sugar 13 (Scheme 5).

Scheme 5: Synthesis of a protected $\beta$-D-olivose 13

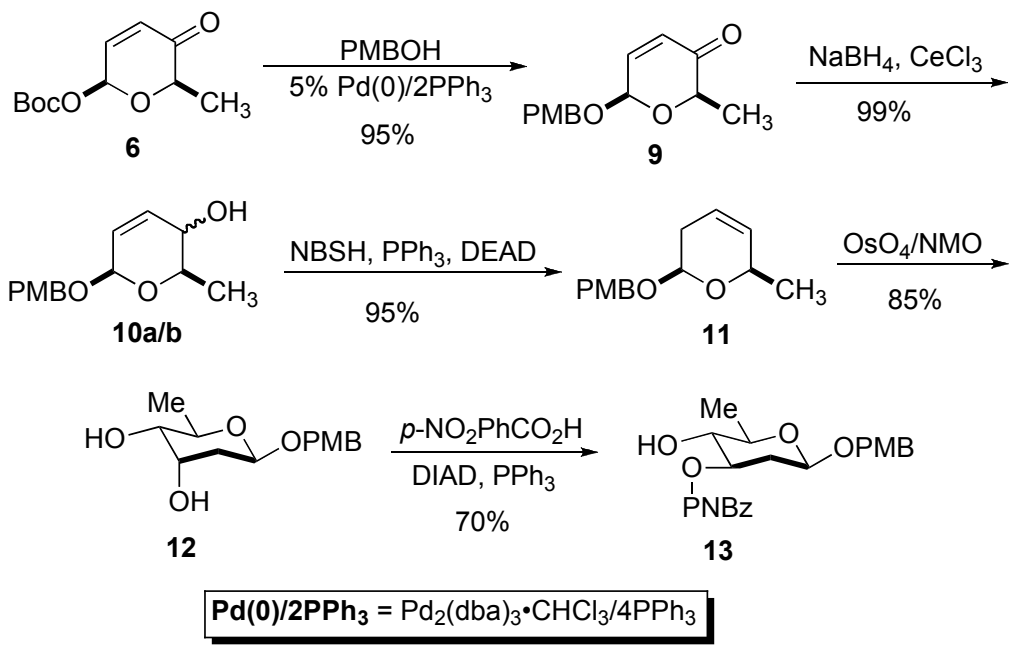

In practice, we began with the palladium-catalyzed glycosylation $(5$ mol\% $\left.\mathrm{Pd}_{2}(\mathrm{dba})_{3}{ }^{\bullet} \mathrm{CHCl}_{3} / 10 \% \mathrm{PPh}_{3}\right)^{\dagger}$ of $\mathrm{PMBOH}$ with the $\beta$-D-pyranone 6 to form the $\beta$-benzyloxy pyranone 9 in $95 \%$ yield as a single diastereomer (Scheme 4). Ketone reduction of pyranone 9 with $\mathrm{NaBH}_{4} / \mathrm{CeCl}_{3}$ gave a mixture of allylic alcohols $\mathbf{1 0 a} / \mathbf{b}$ in $99 \%$ yield $(\mathrm{dr} \sim 1.5$ to 1$)$. Fortunately, both diastereomers 10a/b could be used in the next reaction. Applying the Myers' reductive rearrangement conditions $\left(\mathrm{NBSH}, \mathrm{PPh}_{3} / \mathrm{DEAD}, \mathrm{NMM},-30{ }^{\circ} \mathrm{C} \text { to } \mathrm{rt}\right)^{21}$ to the mixture of

\footnotetext{
${ }^{\dagger}$ To save space in the schemes these typical palladium glycosylation conditions $\left(5 \mathrm{~mol} \% \mathrm{Pd}_{2}\left(\mathrm{dba}_{3} \cdot{ }_{3} \mathrm{CHCl}_{3} / 10 \%\right.\right.$ $\left.\mathrm{PPh}_{3}\right)$ will be refered to as $\left(5 \mathrm{~mol} \% \mathrm{Pd}(0) / 2 \mathrm{PPh}_{3}\right)$ to indicate the percentage of catalyst used in a 1:2 $\mathrm{Pd} / \mathrm{Ligand}$ ratio.
} 
allylic alcohols $\mathbf{1 0 a} / \mathbf{b}$ cleanly provided olefin $\mathbf{1 1}$ in $95 \%$ yield. Finally, exposing olefin $\mathbf{1 1}$ to the Upjohn conditions $\left(\mathrm{OsO}_{4} / \mathrm{NMO}\right)^{22}$ gave exclusively the diol 12 with allo-stereochemistry in $85 \%$ yield. We then turned to our selective diol inversion, subjecting $\mathbf{1 2}$ to the typical Mitsunobu conditions ( $\left.p-\mathrm{NO}_{2} \mathrm{PhCO}_{2} \mathrm{H} / \mathrm{PPh}_{3} / \mathrm{DIAD}\right)$ cleanly converted it into the protected $\beta$-D-olivose $\mathbf{1 3}$ in $70 \%$ yield. A nice feature of this approach is that the nitrobenzoate group also serves as a temporary protecting group.

Scheme 6: Synthesis of a $\beta$-D-olivose/ $\alpha$-L-rhodinose disaccharide 17

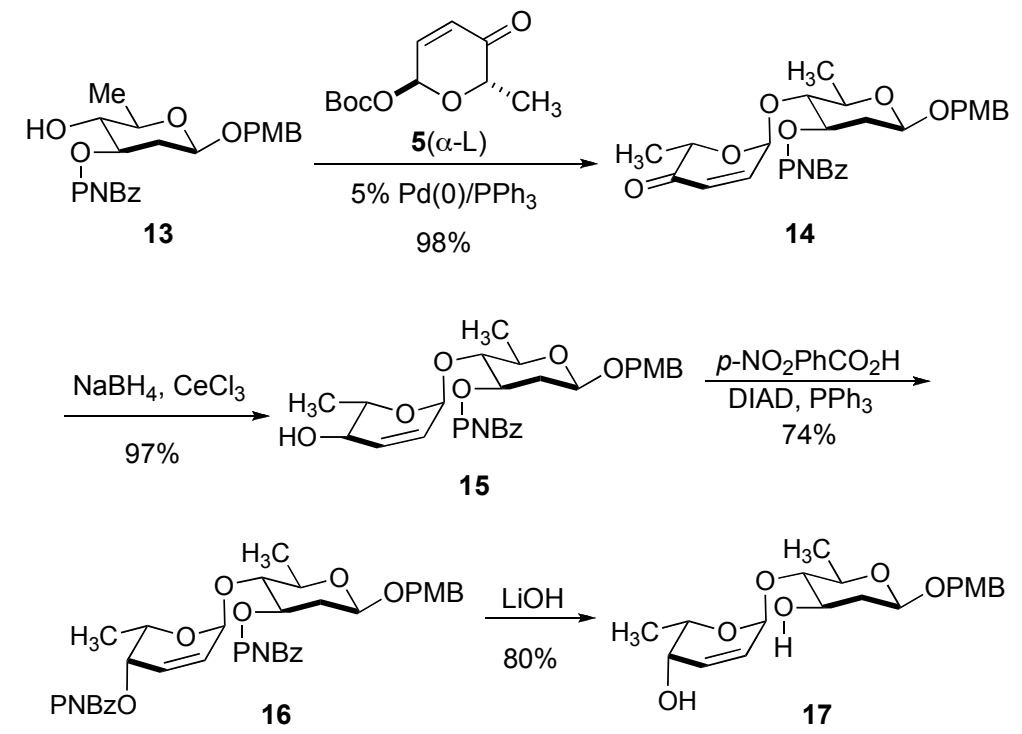

With a viable route to the protected $\beta$-D-olivo-sugar 13 in hand, our efforts turned to the installation of the $\alpha$-L-rhodinose portion (Scheme 5). The olivo-sugar 13 and $\alpha$-L-pyranone 5 were coupled using our typical palladium-catalyzed glycosylation conditions (5 mol\% $\mathrm{Pd}_{2}(\mathrm{dba})_{3} \cdot \mathrm{CHCl}_{3} / 10 \% \mathrm{PPh}_{3}, 98 \%$ yield) to form 14 with complete stereocontrol at the anomeric center. Luche reduction of the keto-group in pyranone $\mathbf{1 4}$ stereoselectively provided allylic alcohol 15 (97\%). At this stage, a Mitsunobu reaction $\left(\mathrm{PPh}_{3} / \mathrm{DIAD} / p-\mathrm{NO}_{2} \mathrm{PhCO}_{2} \mathrm{H}, 74 \%\right)$ was used to afford bis-nitrobenzoate $\mathbf{1 6}$ with inverted stereochemistry at $C-4$. Unfortunately, all 
efforts to differentiate the two $p$-nitrobenzoate groups in $\mathbf{1 6}$ were unsuccessful. As a result, we opted for hydrolyses of both benzoates with excess LiOH which afford diol $17(80 \%)$ and then turned to the selective introduction of the $\alpha$-L-aculose at $C-4$.

Scheme 7: Synthesis of the vineomycin C/PI-080 trisaccharide 19

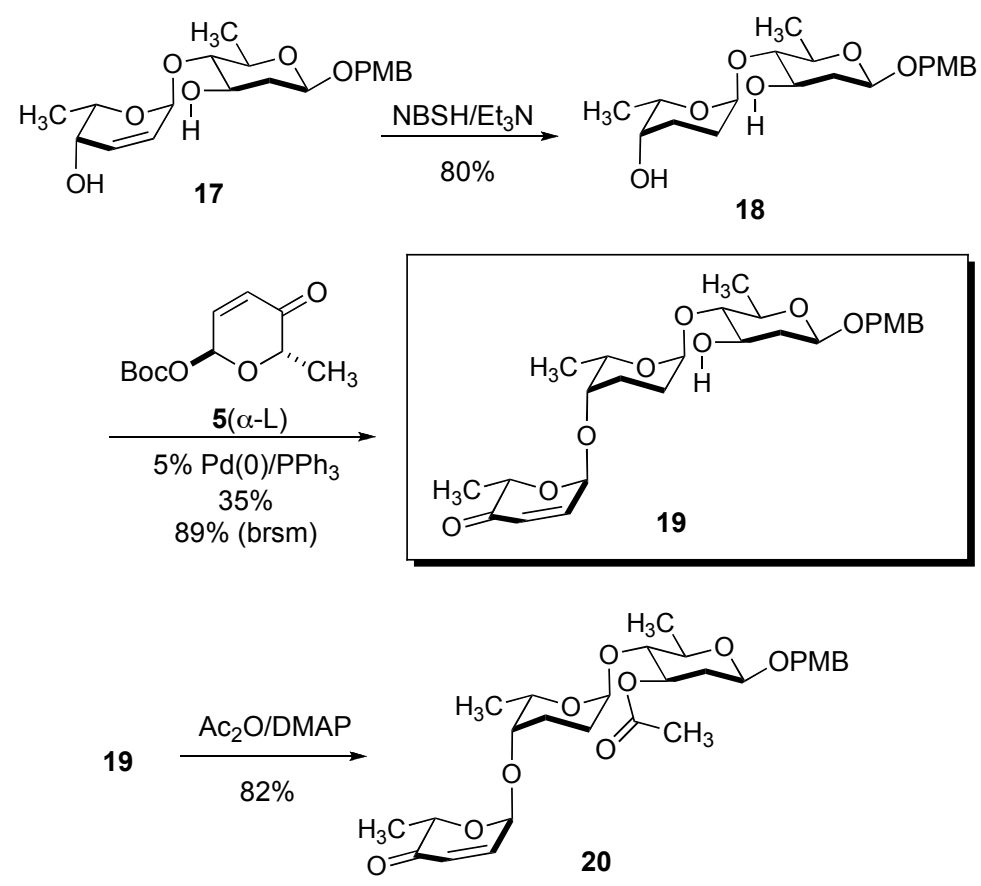

Our investigations of the selective introduction of the $\alpha$-L-aculose at $C$-4 were performed on both diol 17 and diol 18 (Scheme 7), which could easily be prepared by hydrogenation with excess diimide $\left(\mathrm{NBSH} / \mathrm{Et}_{3} \mathrm{~N}, \quad 80 \%\right)$. The Pd-catalyzed glycosylation (5 mol\% $\mathrm{Pd}_{2}(\mathrm{dba})_{3} \cdot \mathrm{CHCl}_{3} / 10 \% \mathrm{PPh}_{3}$ ) of alcohol $\mathbf{1 8}$ with $\alpha$-L-pyranone $\mathbf{5}$ proved to be the better selective method. This was most conveniently performed at low conversion using a slight excess of $\alpha$-Lpyranone 5 under dilute condition to provide $35 \%$ yield of the desired trisaccharide 19, along with $61 \%$ recovered starting material 18 ( $89 \%$ yield, based on recovered starting material). To confirm the regioselectivity of glycosylation, $\mathbf{1 9}$ was acylated with $\mathrm{Ac}_{2} \mathrm{O} / \mathrm{DMAP}$ to form $\mathbf{2 0}$ 
$(82 \%)$. Analysis of the one and two-dimensional NMR data of acetate $\mathbf{2 0}$ indicated that the glycosylation of 18 occurred selectively at the $C$-4 position of the $\alpha$-L-rhodinose sugar. Overall, the trisaccharide 19 was prepared from the achiral 2-acylfuran 8 in 14 steps and $17 \%$ overall yield.

Figure 6: Proof of the regioselective glycosylation by NMR structural assignment of 20

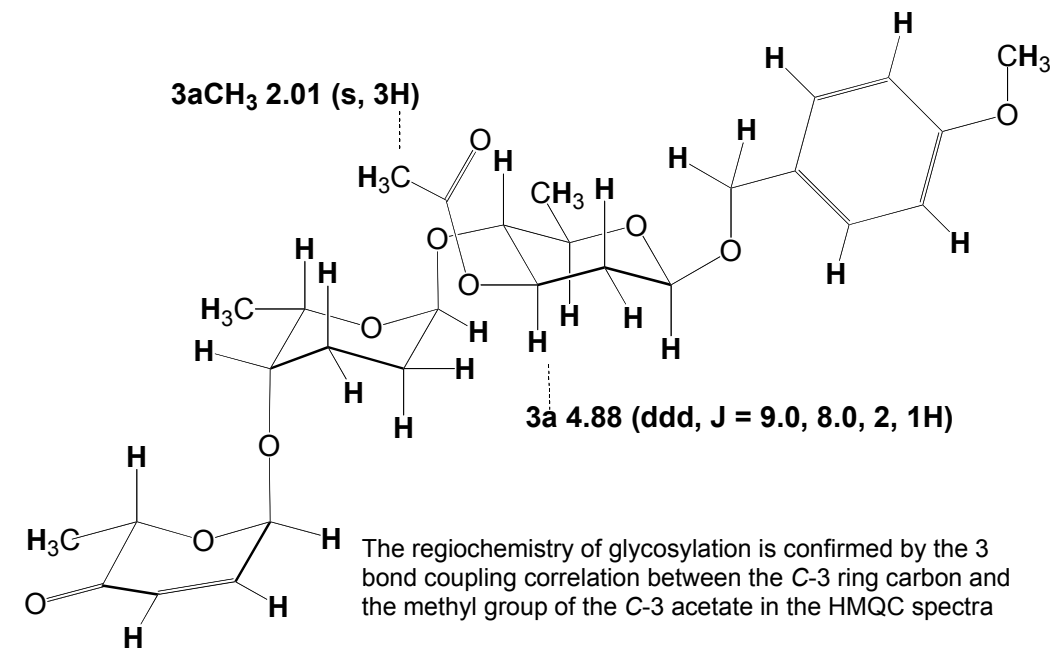

With significant quantities of trisaccharide 19 in hand, we decided to screen it against two types of cancer cell lines from nine different tissue types (Table 1). While we were motivated to test 19 primarily as a control experiement for future studies, we were delighted to find it had wide-ranging cytotoxicity, displaying significant growth inhibition $\left(\mathrm{GI}_{50}\right.$ from 0.1 to $11 \mu \mathrm{M}$ ) and cytotoxicity ( $\mathrm{LC}_{50}$ from 5.1 to $100 \mu \mathrm{M}$ ) against these various cell lines. Indeed, at 50 $\mu \mathrm{M}$, the trisaccharide 19 showed greater cytotoxicity against NCI-H460 Non-Small Cell Lung cancer cells than Cisplatin at $300 \mu \mathrm{M}$ (Figure 7). Interestingly, this level of cytotoxicity is in the range of that found for other glycosylated angucycline antibiotics. ${ }^{23}$ Outlined in Tables 2-10 are the results from the screening against the panel of the NCI's 60 cancer cell lines for the same tissue types. While good to moderate $\mathrm{GI}_{50}(1$ to $20 \mu \mathrm{M})$ values were found across the board, 
significant variation was found for the $\mathrm{LC}_{50}$ values $(5$ to $>100 \mathrm{nM})$.

Table 1: Comparitive cytotoxicity evaluation of trisaccharide 19 across the cell lines

\begin{tabular}{|l|l|c|c|c|}
\hline \multirow{2}{*}{ cell type } & \multirow{2}{*}{ panel/cell line } & \multicolumn{3}{|c|}{$\mathbf{1 9}(\mu M)$} \\
\cline { 3 - 5 } & & GI $_{\mathbf{5 0}}$ & TGI & LC $_{\mathbf{5 0}}$ \\
\hline \multirow{2}{*}{ Leukemia } & RPMI-8226 & 0.12 & 2.80 & $>100$ \\
\cline { 2 - 5 } $\begin{array}{l}\text { Non-Small Cell } \\
\text { Lung }\end{array}$ & NCI-H23 & 1.98 & 4.59 & 12.0 \\
\cline { 2 - 5 } & NCI-H460 & 11.0 & 23.7 & 51.0 \\
\hline Colon & COLO-205 & 1.66 & 3.02 & 5.50 \\
\cline { 2 - 5 } & SW-620 & 1.35 & 2.64 & 5.13 \\
\hline CNS & SF-268 & 3.09 & 9.54 & 31.5 \\
\cline { 2 - 5 } & U251 & 1.82 & 4.10 & 9.26 \\
\hline Melanoma & LOX IMVI & 1.53 & 2.87 & 5.40 \\
\cline { 2 - 5 } & SK-MEL-28 & 1.82 & 3.22 & 5.71 \\
\hline Ovarian & IGROV1 & 1.62 & 3.32 & 6.81 \\
\cline { 2 - 5 } & OVCAR-3 & 1.60 & 2.95 & 5.43 \\
\hline Renal & TK-10 & 2.32 & 6.46 & 23.1 \\
\cline { 2 - 5 } & UO-31 & 1.49 & 2.81 & 5.30 \\
\cline { 2 - 5 } & T-47D & 1.74 & 3.99 & 9.16 \\
\cline { 2 - 5 } & DU-145 & 1.81 & 3.20 & 5.66 \\
\hline \multirow{2}{*}{ Prostate } & MCF7 & 1.63 & 3.38 & 7.04 \\
\hline
\end{tabular}

$\mathbf{G I}_{50}$ : the drug concentration resulting in a $50 \%$ reduction in the net protein increase in control cells.

TGI: the drug concentration resulting in no increase in the measured protein as compared to control cells.

$\mathbf{L C}_{50}$ : the drug concentration resulting in a 50\% reduction in the measured protein as compared to control cells. 
Of all nine tissue types from the NCI panel of 60 cell lines, the trisaccharide 19 showed the worst potency against the leukemia cell line types. While this poor activity was not so obvious from the $\mathrm{GI}_{50}$ growth inhibitory concentrations (ranging from $0.12 \mu \mathrm{M}$ to $7.6 \mu \mathrm{M}$ ), the trend was most clear in the values of $\operatorname{LC}_{50}(>100 \mu \mathrm{M})$. The complete leukemia cell line data for trisaccharide 19 is outlined in Table 2.

Table 2: Leukemia cell cytotoxicity evaluation of trisaccharide 19

\begin{tabular}{|l|l|c|c|c|}
\hline \multirow{2}{*}{$\begin{array}{l}\text { Leukemia } \\
\text { cell type }\end{array}$} & \multirow{2}{*}{ panel/cell line } & \multicolumn{3}{|c|}{ 19 $(\mu M)$} \\
\cline { 3 - 5 } & & GI $_{\mathbf{5 0}}$ & TGI & LC $_{\mathbf{5 0}}$ \\
\cline { 2 - 5 } & CCRF-CEM & 0.30 & $>100$ & $>100$ \\
\cline { 2 - 5 } & HL-60(TB) & 0.65 & $>100$ & $>100$ \\
\cline { 2 - 5 } & K-562 & 7.6 & $>100$ & $>100$ \\
\cline { 2 - 5 } & MOLT-4 & 4.8 & $>100$ & $>100$ \\
\cline { 2 - 5 } & RPMI-8226 & 0.12 & 2.80 & $>100$ \\
\cline { 2 - 5 } & SR & 0.60 & 19.0 & $>100$ \\
\hline
\end{tabular}

$\mathbf{G I}_{\mathbf{5 0}}$ : the drug concentration resulting in a 50\% reduction in the net protein increase in control cells.

TGI: the drug concentration resulting in no increase in the measured protein as compared to control cells.

$\mathbf{L C}_{\mathbf{5 0}}$ : the drug concentration resulting in a $50 \%$ reduction in the measured protein as compared to control cells.

The trisaccharide 19 showed much better potency against the Non-Small Cell Lung cancer cell line than the leukemia cell line. The best activities came against the NCI-H23 $\left(\mathrm{GI}_{50}=\right.$ $1.98 \mu \mathrm{M}$ and $\left.\mathrm{LC}_{50}=12.0 \mu \mathrm{M}\right)$ and NCI-H522 $\left(\mathrm{GI}_{50}=1.10 \mu \mathrm{M}\right.$ and $\left.\mathrm{LC}_{50}=5.41 \mu \mathrm{M}\right)$ cell lines and the poorest activity came against the A459/ATCC $\left(\mathrm{GI}_{50}=16.9 \mu \mathrm{M}\right.$ and $\left.\mathrm{LC}_{50}=60.8 \mu \mathrm{M}\right)$ and HOP-62 $\left(\mathrm{GI}_{50}=20.6 \mu \mathrm{M}\right.$ and $\left.\mathrm{LC}_{50}=61.7 \mu \mathrm{M}\right)$ cell lines. The complete Non-Small Cell Lung (NSCL) cell line data for trisaccharide $\mathbf{1 9}$ is outlined in Table 3. 
Table 3: NSCL cancer cell cytotoxicity evaluation of trisaccharide 19

\begin{tabular}{|c|c|c|c|c|}
\hline \multirow{10}{*}{$\begin{array}{c}\text { Non-Small Cell } \\
\text { Lung } \\
\text { cell type }\end{array}$} & & \multicolumn{3}{|c|}{$19(\mu M)$} \\
\hline & & GI 50 & TGI & $\mathbf{L C}_{50}$ \\
\hline & A459/ATCC & 16.9 & 32.0 & 60.8 \\
\hline & HOP-62 & 20.6 & 35.6 & 61.7 \\
\hline & HOP-92 & 1.58 & 4.44 & 19.1 \\
\hline & NCI-H226 & 13.7 & 26.6 & 51.6 \\
\hline & NCI-H23 & 1.98 & 4.59 & 12.0 \\
\hline & NCI-H322M & 16.2 & 30.1 & 56.0 \\
\hline & NCI-H460 & 11.0 & 23.7 & 51.0 \\
\hline & NCI-H522 & 1.10 & 2.44 & 5.41 \\
\hline
\end{tabular}

$\mathbf{G I}_{\mathbf{5 0}}$ : the drug concentration resulting in a $50 \%$ reduction in the net protein increase in control cells.

TGI: the drug concentration resulting in no increase in the measured protein as compared to control cells.

$\mathbf{L C}_{50}$ : the drug concentration resulting in a 50\% reduction in the measured protein as compared to control cells.

The trisaccharide 19 showed excellent potency across the board against the colon cancer cell lines, with only the HC-2998 cell line showing $\mathrm{LC}_{50}$ values above $10 \mu \mathrm{M}$. All the other cell lines had $\mathrm{GI}_{50}$ values between 1-2 $\mu \mathrm{M}$ concentrations and $\mathrm{LC}_{50}$ values between 5-7 $\mu \mathrm{M}$ concentrations. The complete colon cancer cell line data for trisaccharide $\mathbf{1 9}$ is outlined in Table 4. 
Table 4: Colon Cancer cell cytotoxicity evaluation of trisaccharide 19

\begin{tabular}{|c|c|c|c|c|}
\hline \multirow{2}{*}{$\begin{array}{c}\text { Colon Cancer } \\
\text { cell type }\end{array}$} & \multirow{2}{*}{ panel/cell line } & \multicolumn{3}{|c|}{$19(\mu M)$} \\
\hline & & GI $_{50}$ & TGI & $\mathrm{LC}_{50}$ \\
\hline & COLO-205 & 1.66 & 3.02 & 5.50 \\
\hline & HC-2998 & 3.56 & 11.8 & 34.4 \\
\hline & НCТ-116 & 1.18 & 2.53 & 5.46 \\
\hline & HCT-15 & 1.50 & 3.04 & 6.15 \\
\hline & HT29 & 1.53 & 2.86 & 5.46 \\
\hline & KM12 & 1.67 & 3.30 & 6.55 \\
\hline & SW-620 & 1.35 & 2.64 & 5.13 \\
\hline
\end{tabular}

$\mathbf{G I}_{\mathbf{5 0}}$ : the drug concentration resulting in a $50 \%$ reduction in the net protein increase in control cells.

TGI: the drug concentration resulting in no increase in the measured protein as compared to control cells.

$\mathbf{L C}_{\mathbf{5 0}}$ : the drug concentration resulting in a 50\% reduction in the measured protein as compared to control cells.

The trisaccharide 19 showed lesser potency against the panel of central nerous system cancer cell lines than the colon cell lines. The best inhibitory activities came against the U251 $\left(\mathrm{GI}_{50}=1.82 \mu \mathrm{M}\right.$ and $\left.\mathrm{LC}_{50}=9.26 \mu \mathrm{M}\right)$ and the poorest activity came against the $\mathrm{SF} 295\left(\mathrm{GI}_{50}=\right.$ $13.7 \mu \mathrm{M}$ and $\left.\mathrm{LC}_{50}=54.7 \mu \mathrm{M}\right)$ cell lines. The complete central nervous system (CNS) cell line data for trisaccharide 19 is outlined in Table 5. 
Table 5: CNS Cancer cell cytotoxicity evaluation of trisaccharide 19

\begin{tabular}{|l|l|c|c|c|}
\hline \multirow{2}{*}{$\begin{array}{l}\text { CNS } \\
\text { cell type }\end{array}$} & \multirow{2}{*}{\begin{tabular}{c} 
panel/cell line \\
\cline { 2 - 5 }
\end{tabular}} & & \multicolumn{3}{|c|}{ 19(uM) } \\
\cline { 2 - 5 } & GI $_{\mathbf{5 0}}$ & TGI & LC $_{\mathbf{5 0}}$ \\
\hline \multirow{7}{*}{ SF-268 } & 3.09 & 9.54 & 31.5 \\
\cline { 2 - 5 } & SF295 & 13.7 & 27.4 & 54.7 \\
\cline { 2 - 5 } & SF-539 & 3.33 & 13.7 & 37.1 \\
\cline { 2 - 5 } & SNB-19 & 12.2 & 24.6 & 49.6 \\
\cline { 2 - 5 } & SNB-75 & 1.11 & 12.2 & 34.9 \\
\cline { 2 - 5 } & U251 & 1.82 & 4.10 & 9.26 \\
\hline
\end{tabular}

GI $_{50}$ : the drug concentration resulting in a $50 \%$ reduction in the net protein increase in control cells.

TGI: the drug concentration resulting in no increase in the measured protein as compared to control cells.

$\mathbf{L C}_{50}$ : the drug concentration resulting in a $50 \%$ reduction in the measured protein as compared to control cells.

The trisaccharide 19 showed lesser potency against the panel of Melanoma cancer cell lines than the CNS cell lines. The best inhibitory activities came against the LOXIMVI $\left(\mathrm{GI}_{50}=\right.$ $1.53 \mu \mathrm{M}$ and $\left.\mathrm{LC}_{50}=5.40 \mu \mathrm{M}\right)$ and SK-MEL-28 $\left(\mathrm{GI}_{50}=1.82 \mu \mathrm{M}\right.$ and $\left.\mathrm{LC}_{50}=5.71 \mu \mathrm{M}\right)$, with the poorest activity came against the UACC-257 $\left(\mathrm{GI}_{50}=13.9 \mu \mathrm{M}\right.$ and $\left.\mathrm{LC}_{50}=53.8 \mu \mathrm{M}\right)$ cell lines. The complete melanoma cancer cell line data for trisaccharide $\mathbf{1 9}$ is outlined in Table 6. 
Table 6: Melanoma Cancer cell cytotoxicity evaluation of trisaccharide 19

\begin{tabular}{|c|c|c|c|c|}
\hline \multirow{2}{*}{$\begin{array}{c}\text { Melanoma } \\
\text { cell type }\end{array}$} & \multirow{2}{*}{ panel/cell line } & \multicolumn{3}{|c|}{$19(u M)$} \\
\hline & & GI $_{50}$ & TGI & $\mathrm{LC}_{50}$ \\
\hline & LOX IMVI & 1.53 & 2.87 & 5.40 \\
\hline & MALME-3M & 2.0 & 5.23 & 20.9 \\
\hline & M14 & 2.74 & 10.9 & 33.0 \\
\hline & SK-MEL-2 & 2.58 & 6.97 & 24.5 \\
\hline & SK-MEL-28 & 1.82 & 3.22 & 5.71 \\
\hline & SK-MEL-5 & 8.19 & 20.6 & 45.4 \\
\hline & UACC-257 & 13.9 & 27.3 & 53.8 \\
\hline & UACC-62 & 3.89 & 14.4 & 38.0 \\
\hline
\end{tabular}

$\mathbf{G I}_{\mathbf{5 0}}$ : the drug concentration resulting in a $50 \%$ reduction in the net protein increase in control cells.

TGI: the drug concentration resulting in no increase in the measured protein as compared to control cells.

$\mathbf{L C}_{50}$ : the drug concentration resulting in a 50\% reduction in the measured protein as compared to control cells.

The trisaccharide 19 showed the best across the board potency against the panel of ovarian cancer cell lines, with all but the OVCAR-4 and OVACR- 8 LC 50 values being below 10 $\mu \mathrm{M}$. The best activities were for the OVACR-3 $\left(\mathrm{GI}_{50}=1.60 \mu \mathrm{M}\right.$ and $\left.\mathrm{LC}_{50}=5.43 \mu \mathrm{M}\right)$ and SKOV-3 $\left(\mathrm{GI}_{50}=1.60 \mu \mathrm{M}\right.$ and $\left.\mathrm{LC}_{50}=5.43 \mu \mathrm{M}\right)$, with the poorest activity against the OVACR-4 $\left(\mathrm{GI}_{50}=1.80 \mu \mathrm{M}\right.$ and $\left.\mathrm{LC}_{50}=28.5 \mu \mathrm{M}\right)$ and OVACR-8 $\left(\mathrm{GI}_{50}=3.08 \mu \mathrm{M}\right.$ and $\left.\mathrm{LC}_{50}=33.8 \mu \mathrm{M}\right)$ cell lines. The complete ovarian cancer cell line data for trisaccharide 19 is outlined in Table 7. 
Table 7: Ovarian Cancer cell cytotoxicity evaluation of trisaccharide 19

\begin{tabular}{|c|c|c|c|c|}
\hline \multirow{2}{*}{$\begin{array}{c}\text { Ovarian Cancer } \\
\text { cell type }\end{array}$} & \multirow{2}{*}{ panel/cell line } & \multicolumn{3}{|c|}{$19(\mu M)$} \\
\hline & & GI 50 & TGI & $\mathbf{L C}_{50}$ \\
\hline & IGROV1 & 1.62 & 3.32 & 6.81 \\
\hline & OVCAR-3 & 1.60 & 2.95 & 5.43 \\
\hline & OVCAR-4 & 1.80 & 7.83 & 28.5 \\
\hline & OVCAR-5 & 1.89 & 3.73 & 7.38 \\
\hline & OVACR-8 & 3.08 & 11.2 & 33.8 \\
\hline & SK-OV-3 & 1.60 & 2.95 & 5.43 \\
\hline
\end{tabular}

$\mathbf{G I}_{50}$ : the drug concentration resulting in a $50 \%$ reduction in the net protein increase in control cells.

TGI: the drug concentration resulting in no increase in the measured protein as compared to control cells.

$\mathbf{L C}_{\mathbf{5 0}}$ : the drug concentration resulting in a 50\% reduction in the measured protein as compared to control cells.

The trisaccharide 19 showed variable potency against the panel of renal cancer cell lines, with $\mathrm{LC}_{50}$ values ranging from $10 \mu \mathrm{M}$ to $51.5 \mu \mathrm{M}$. The best activities were for the UO-31 $\left(\mathrm{GI}_{50}\right.$ $=1.49 \mu \mathrm{M}$ and $\left.\mathrm{LC}_{50}=5.30 \mu \mathrm{M}\right)$, with the poorest activity against the $786-0\left(\mathrm{GI}_{50}=5.10 \mu \mathrm{M}\right.$ and $\left.\mathrm{LC}_{50}=40.6 \mu \mathrm{M}\right)$ and $\mathrm{A} 498\left(\mathrm{GI}_{50}=1.37 \mu \mathrm{M}\right.$ and $\left.\mathrm{LC}_{50}=51.5 \mu \mathrm{M}\right)$ cell lines. The complete Renal cancer cell line data for trisaccharide $\mathbf{1 9}$ is outlined in Table 8. 
Table 8: Renal Cancer cell cytotoxicity evaluation of trisaccharide 19

\begin{tabular}{|c|c|c|c|c|}
\hline \multirow{2}{*}{$\begin{array}{c}\text { Renal Cancer } \\
\text { cell type }\end{array}$} & \multirow{2}{*}{ panel/cell line } & \multicolumn{3}{|c|}{$\underline{19(\mu M)}$} \\
\hline & & GI $_{50}$ & TGI & $L^{L} C_{50}$ \\
\hline & $786-0$ & 5.10 & 16.5 & 40.6 \\
\hline & A498 & 1.37 & 2.66 & 51.5 \\
\hline & $\mathrm{ACHN}$ & 1.83 & 3.92 & 8.39 \\
\hline & CAKI-1 & 1.97 & 5.98 & 22.3 \\
\hline & RXF-393 & 1.53 & 3.44 & 7.74 \\
\hline & SN12C & 1.94 & 4.53 & 11.5 \\
\hline & TK-10 & 2.30 & 6.46 & 23.1 \\
\hline & UO-31 & 1.49 & 2.81 & 5.30 \\
\hline
\end{tabular}

GI $_{50}$ : the drug concentration resulting in a 50\% reduction in the net protein increase in control cells.

TGI: the drug concentration resulting in no increase in the measured protein as compared to control cells.

$\mathbf{L C}_{\mathbf{5 0}}$ : the drug concentration resulting in a 50\% reduction in the measured protein as compared to control cells.

Although it only contains two cell lines, the trisaccharide 19 showed excellent potency against the panel of prostate cancer cell lines, with $\mathrm{LC}_{50}$ values below $10 \mu \mathrm{M}$. The best inhibitory activities were found for the DU-145 $\left(\mathrm{GI}_{50}=1.81 \mu \mathrm{M}\right.$ and $\left.\mathrm{LC}_{50}=5.66 \mu \mathrm{M}\right)$ cell lines, with the excellent although lower activity against the PC-3 $\left(\mathrm{GI}_{50}=1.74 \mu \mathrm{M}\right.$ and $\left.\mathrm{LC}_{50}=9.16 \mu \mathrm{M}\right)$ cell lines. The complete prostate cancer cell line data for trisaccharide 19 is outlined in Table 9. 
Table 9: Prostate Cancer cell cytotoxicity evaluation of trisaccharide 19

\begin{tabular}{|l|l|c|c|c|}
\hline \multirow{2}{*}{$\begin{array}{c}\text { Prostate Cancer } \\
\text { cell type }\end{array}$} & \multirow{2}{*}{ panel/cell line } & \multicolumn{3}{|c|}{ 19 $(\mu M)$} \\
\cline { 3 - 5 } & & GI $_{\mathbf{5 0}}$ & TGI & LC $_{\mathbf{5 0}}$ \\
\hline \multirow{3}{*}{} & PC-3 & 1.74 & 3.99 & 9.16 \\
\cline { 2 - 5 } & DU-145 & 1.81 & 3.20 & 5.66 \\
\hline
\end{tabular}

$\mathbf{G I}_{50}$ : the drug concentration resulting in a 50\% reduction in the net protein increase in control cells.

TGI: the drug concentration resulting in no increase in the measured protein as compared to control cells.

$\mathbf{L C}_{\mathbf{5 0}}$ : the drug concentration resulting in a $50 \%$ reduction in the measured protein as compared to control cells.

The trisaccharide 19 showed the most variable potency against the panel of breast cancer cell lines, with $\mathrm{LC}_{50}$ values ranging from $5 \mu \mathrm{M}$ to $>100 \mu \mathrm{M}$. The best activities were for the MDA-MB-468 $\left(\mathrm{GI}_{50}=1.24 \mu \mathrm{M}\right.$ and $\left.\mathrm{LC}_{50}=4.99 \mu \mathrm{M}\right)$, with the poorest activity against the NCI/ADR-RES $\left(\mathrm{GI}_{50}=2.53 \mu \mathrm{M}\right.$ and $\left.\mathrm{LC}_{50}>100 \mu \mathrm{M}\right)$ and $\mathrm{HS} 578 \mathrm{~T}\left(\mathrm{GI}_{50}=2.51 \mu \mathrm{M}\right.$ and $\mathrm{LC}_{50}>$ $100 \mu \mathrm{M})$ cell lines. The complete breast cancer cell line data for trisaccharide $\mathbf{1 9}$ is outlined in Table 10. 
Table 10: Breast Cancer cell cytotoxicity evaluation of trisaccharide

19

\begin{tabular}{|l|l|c|c|c|}
\hline \multirow{2}{*}{$\begin{array}{c}\text { Breast Cancer } \\
\text { cell type }\end{array}$} & \multirow{2}{*}{ panel/cell line } & \multicolumn{3}{|c|}{$19(\mu M)$} \\
\cline { 3 - 5 } & & GI 50 & TGI & LC $_{50}$ \\
\hline \multirow{5}{*}{ MCF7 } & 1.63 & 3.38 & 7.04 \\
\cline { 2 - 5 } & NCI/ADR-RES & 2.53 & 6.61 & $>100$ \\
\cline { 2 - 5 } & $\begin{array}{l}\text { MDA-MB- } \\
\text { 231/ATCC }\end{array}$ & 2.61 & 7.26 & 25.5 \\
\cline { 2 - 5 } & HS 578T & 2.51 & 8.0 & $>100$ \\
\cline { 2 - 5 } & MDA-MB-435 & 3.74 & 15.1 & 39.7 \\
\cline { 2 - 5 } & BT-549 & 10.9 & 23.3 & 49.6 \\
\cline { 2 - 5 } & T-47D & 1.42 & 2.77 & 54.1 \\
\cline { 2 - 5 } & MDA-MB-468 & 1.24 & 2.49 & 4.99 \\
\hline
\end{tabular}

$\mathbf{G I}_{\mathbf{5 0}}$ : the drug concentration resulting in a $50 \%$ reduction in the net protein increase in control cells.

TGI: the drug concentration resulting in no increase in the measured protein as compared to control cells.

$\mathbf{L C}_{\mathbf{5 0}}$ : the drug concentration resulting in a 50\% reduction in the measured protein as compared to control cells.

We decided to further study the mechanism of cytotoxicity of $\mathbf{1 9}$ towards human H460 lung epithelial cancer cells (Figure 7). H460 human lung epithelial cells were treated with trisaccharide 19 at a range of concentrations $(50,100$ and $200 \mu \mathrm{M})$ and compared to Cisplatin at $300 \mu \mathrm{M}$ as a control. To ascertain the mechanism of cell death (Figure 8), the samples were then stained with to dyes, propidium iodide (PI, $30 \mathrm{mg} / \mathrm{ml})$ and $1 \mu \mathrm{g} / \mathrm{ml} \mathrm{Hoechst} \mathrm{(HT,} 1 \mathrm{mg} / \mathrm{ml})$. Apoptotic cells appeared shrunken with condensed nuclei and stain only with Hoechst, whereas cells that have undergone apoptosis-dependent or apoptosis-independent necrosis stained with both PI and Hoechst. By comparing these staining differences, the level of toral cell death and percent cell death by apoptosis can be determined. 
Figure 7: Cytotoxicity of 19/Cisplatin towards H460

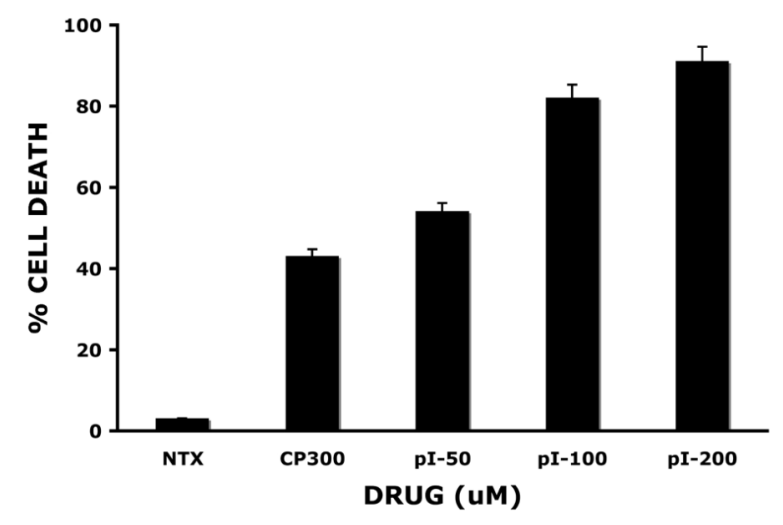

Graph denotes total cell death (apoptosis+necrosis) observed upon treatment of $\mathrm{H} 460$ cells with either no drug (NTX), $300 \mathrm{uM}$ cisplatin (CP300), $50 \mathrm{uM}$ of 19 (PI-50), $100 \mathrm{uM}$ of 19 (PI-100), $200 \mathrm{uM}$ of 19 (PI-200).

At $50 \mu \mathrm{M}$ of trisaccharide 19, the $\mathrm{H} 460$ cells stained mainly for Hoechst and displayed condensed nuclear bodies without significant uptake of propidium iodide, suggesting that cell death was due primarily to apoptosis. However, at higher concentrations of $\mathbf{1 9}(100 \mu \mathrm{M}$ and 200 $\mu \mathrm{M})$, cell death predominantly occurred via necrosis, which was indicated by PI staining without nuclear bodies. 
Figure 8: Mechanism of cell death apoptosis/necrosis
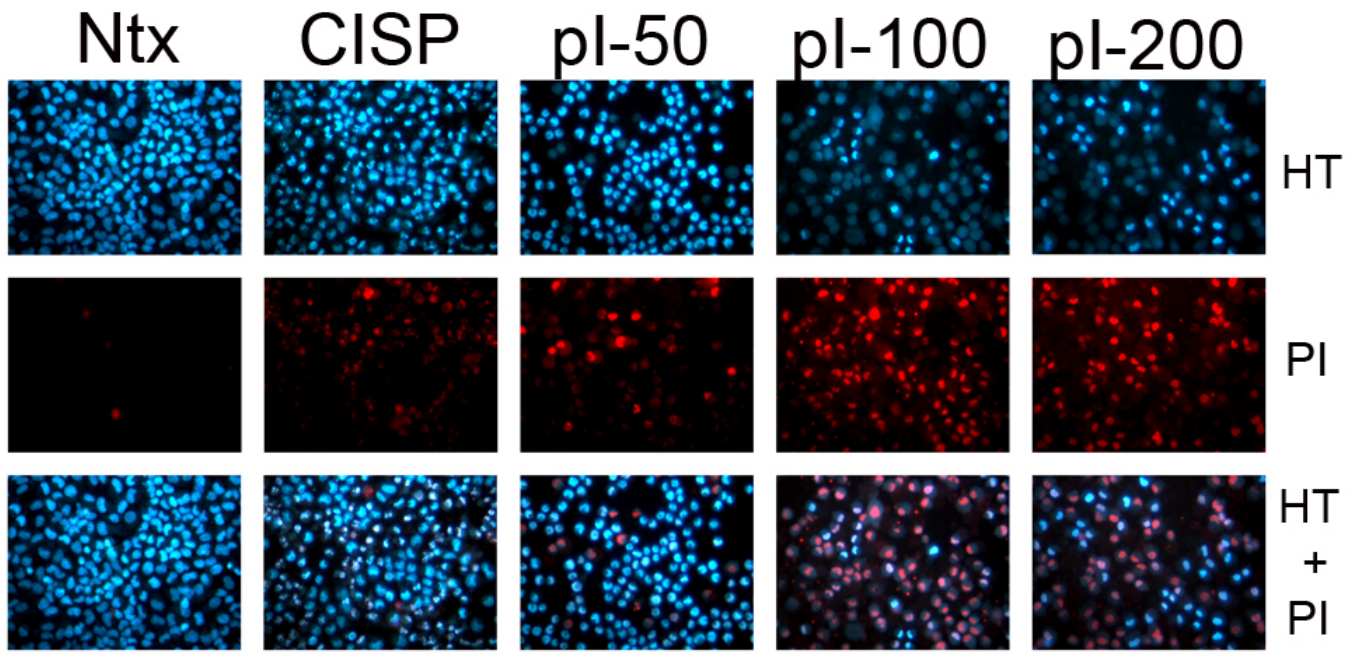

H460 lung epithelial cancer cells were treated with either Cisplatin $(300 \mu \mathrm{M})$ or $19(50,100$ and $200 \mu \mathrm{M})$ for $8 \mathrm{~h}$ in serum free medium, following which each well was incubated in $30 \mu \mathrm{g} / \mathrm{ml}$ propidium iodide (PI) and $1 \mu \mathrm{g} / \mathrm{ml}$ Hoechst (HT) for $30 \mathrm{~min}$.

Images show cells stained for Hoechst alone (top panel, blue), PI alone (middle panel, red), or both.

In summary, a practical route to vineomycin C/PI-080 trisaccharide $\mathbf{1 9}$ has been developed. This route provided significant amounts of material for biological testing. The trisaccharide 19 was shown to suppress the proliferation of several human cancer cell lines via an apoptotic mechanism at $50 \mu \mathrm{M}$. Although it should be noted that when 19 was tested at higher concentrations (100 and $200 \mu \mathrm{M})$ a significant amount of necrosis was also detected. This synthetic/biological study establishes for the first time the importance of the trisaccharide portion to the SAR to these molecules. To gain a better understanding of how the 3-D structure of 19 relates to its biological activity, we decided to synthesize and test the (L,L,D)-enantiomer of 19 (Figure 9), which we believed would allow us to determine if the cytotoxicity toward the cancer 
cells were due to specific interactions with $\mathbf{1 9}$ or the general toxicity of various functional groups like pyranones and/or PMB-ethers.

Figure 9: The (D,D,L)-trisaccharide 19 and the (L,L,D)-trisaccharide ent-19
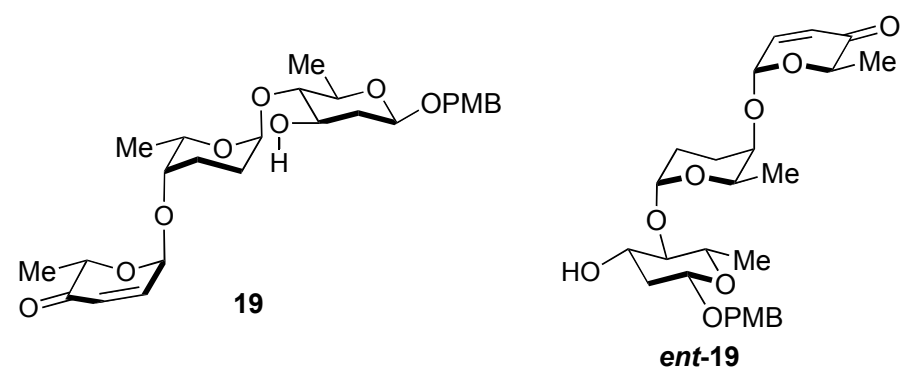

Retrosynthetically, ent-19 was envisioned as coming from two units of ent-5( $\alpha-\mathbf{D})$ and one unit of ent-6( $\beta-\mathrm{L})$. Thus, by an identical process as described above, ent-6( $\beta-\mathrm{L})$ can be converted into ent-13, which can be coupled with ent-5( $\boldsymbol{\alpha}-\mathbf{D})$ to form ent-18. Finally, ent-18 can be coupled with ent-5( $\boldsymbol{\alpha}-\mathrm{D})$ to give ent-19, the (L,L,D)-enantiomer of trisaccharide $\mathbf{1 9}$.

Scheme 8: Retrosynthesis the enantiomer of trisaccharide ent-19

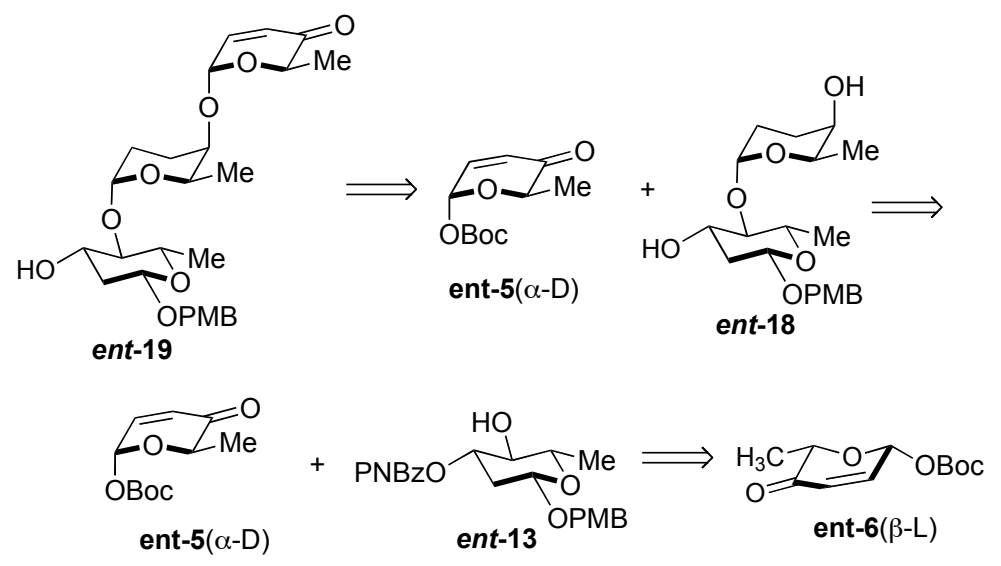


In practice, the synthesis of the enantiomeric series began with the glycosylation of PMBOH with $\boldsymbol{e n t - 6}$ to give $\boldsymbol{e n t - 9}$ (99\% yield). The Luche reduction of $\boldsymbol{e n t - 9}$ gave a good yield of a mixture of allylic alcohols ent-10a/b (99\% yield). The mixture of diastereomeric alcohols $\boldsymbol{e n t - 1 0 a / b}$ were reductively rearranged using the Myer's procedure to give alcohols ent-11 (99\% yield). UpJohn dihydroxylation of ent-11 cleanly gave diol ent-12 (86\% yield). Finally the Lolivose sugar ent-13 was prepared by the regioselective Mitsunobu invesion of diol ent-12 (70\% yield).

Scheme 9: Retrosynthesis the enantiomer of monosaccharide ent-13

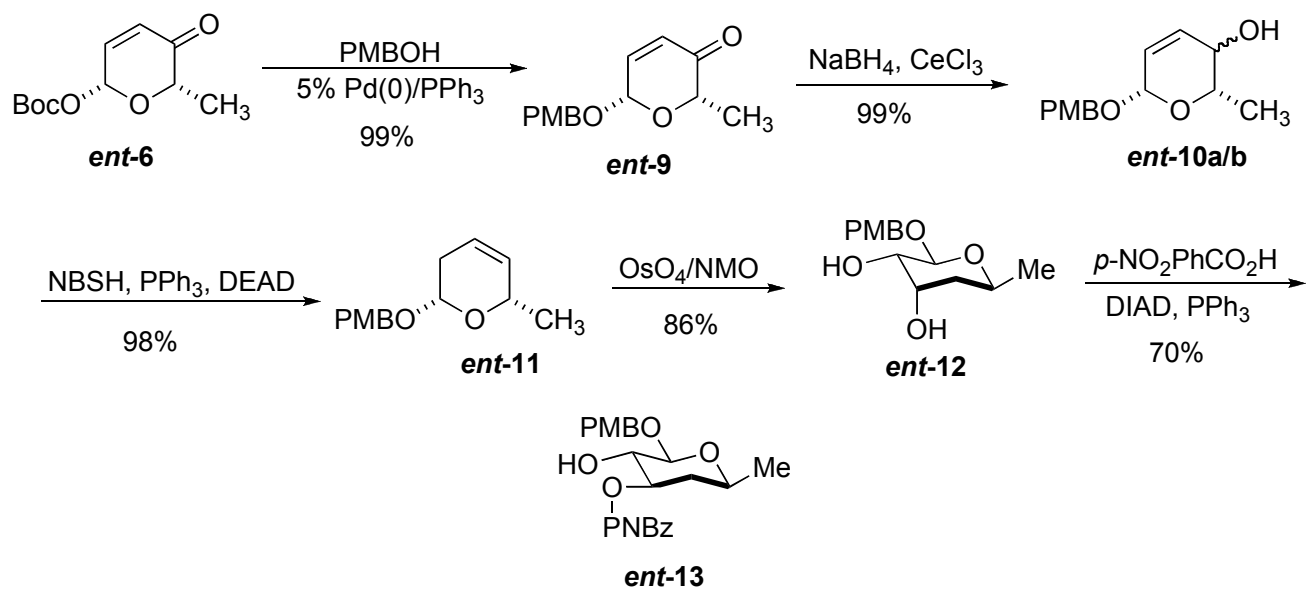

Similarly, the synthesis of the of D,L-disaccharide ent-18 began with the glycosylation of ent-13 with ent-6 ( $87 \%$ yield). The Luche reduction of $\boldsymbol{e n t - 1 4}$ gave the allylic alcohols ent-15 (97\% yield). Mitsunobu inversion of ent-15 with $p$-nitrobenzoic acid gave the bis-nitrobenzoate ent-16 (74\% yield). The two esters were hydrolyzed with excess $\mathrm{LiOH}(80 \%)$ and the double bond was hydrogenated with excess diimide $\left(\mathrm{NBSH} / \mathrm{Et}_{3} \mathrm{~N}\right)$ to give the D,L-disaccharide ent-18. 
Scheme 10: Retrosynthesis the enantiomer of D,L-disaccharide ent-18

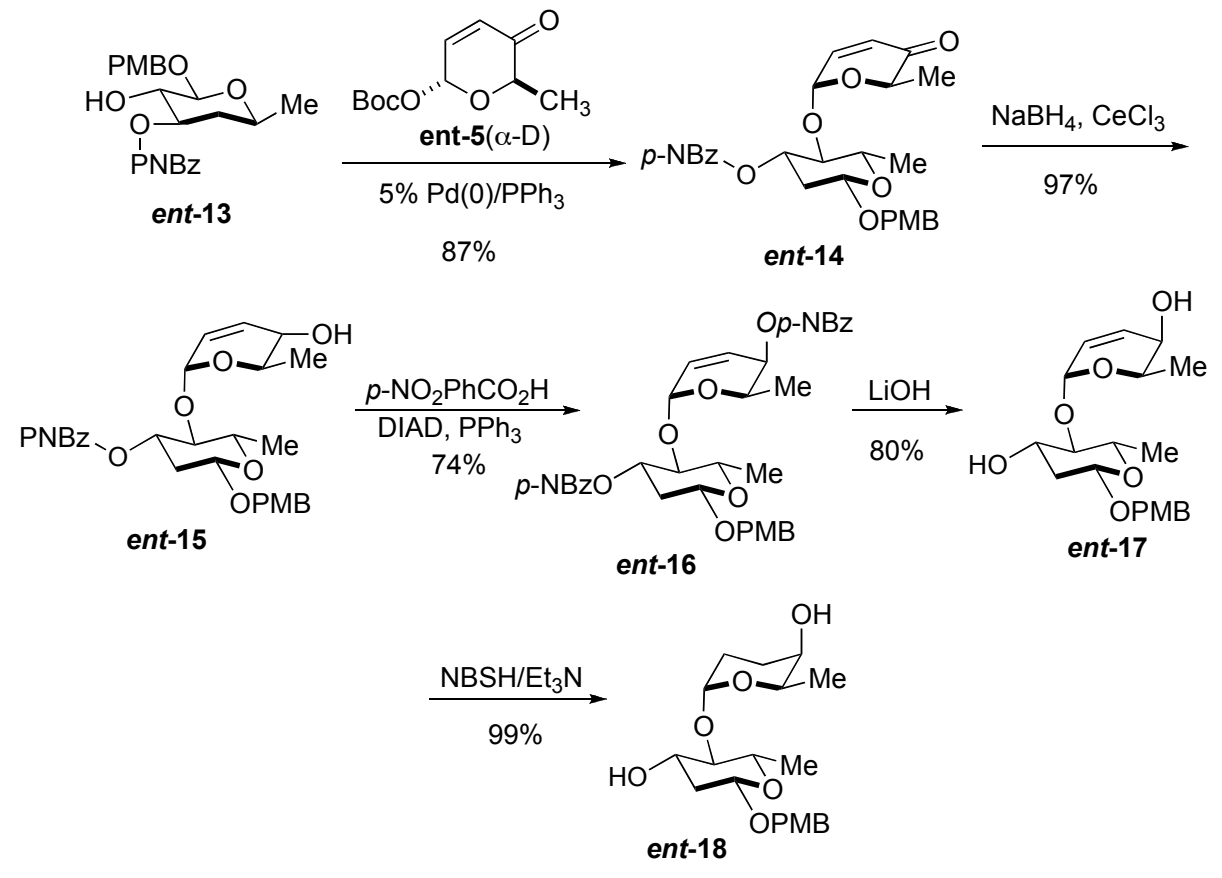

Finally the disaccharide $\boldsymbol{e n t} \mathbf{- 1 8}$ was regioselectively glycosylated with $\boldsymbol{e n t} \mathbf{- 5}(\alpha-\mathrm{D})$ at low conversion to give $40 \%$ of the desired trisaccaride ent-19 along with $50 \%$ recovered starting material. Material from this synthesis was sent to NCI for evaluation in their 60 cell line screen.

Scheme 11: Retrosynthesis the enantiomer of trisaccharide ent-19

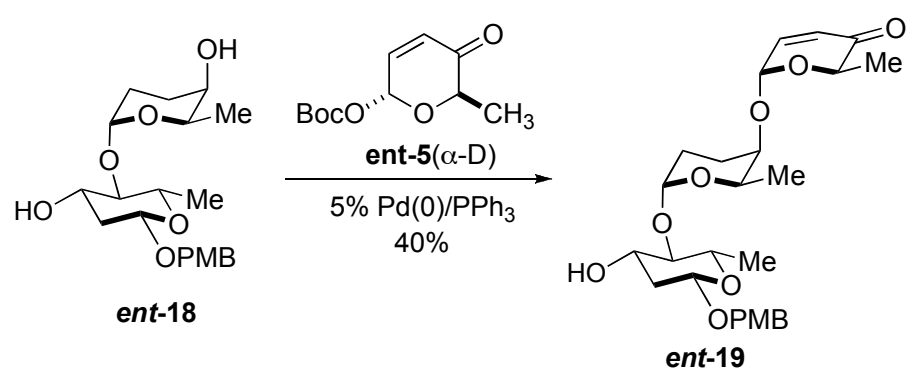


In conclusion, a highly enantioselective de novo route to vineomycin C/PI-080 trisaccharide 19 and its enantiomer (ent-19) has been achieved. The trisaccharide 19 was extensively studied as an anti-cancer agent as well as mechanism of action studies. These studies demonstrated 19's ability to suppress the proliferation of several human cancer cell lines via an apoptotic mechanism at $50 \mu \mathrm{M}$, which demonstrated for the first time that the sugar portion of these type of natural products can contribute to its anti-cancer activity. It should be noted that when 19 was tested at higher concentrations (100 and $200 \mu \mathrm{M})$, a significant amount of necrosis was also detected, which may suggest its cancer cell toxicity may occure via multiple modes of action. To further explore the mechanism of action a synthesis of ent-19 was undertaken. The synthesis of the ent-19 was also completed and samples were submitted to NCI for biological evaluation. The preparation of the other diastereomers and further biological investigation are ongoing. 


\section{Chapter II. Application of De Novo Syntheis Towards the Synthesis of}

\section{C-Aryl Glycoside Natural Products}

Building on the successful synthesis of the trisaccharide portion of PI-080/Vineomycin C, we decided to next try to explore new methods for installing the $C$-Aryl glycoside portion of PI080 and Vineomycin C. This was initially envisioned as being a model study, however, it was hoped that these efforts would eventually lead to the first synthesis of Vineomycin C. At the outset, we were aware of the successful syntheses of Vineomycinone B2 methyl ester by others and believed that our previously described methodology could be used to install the remaing two

sugars (Scheme 12). ${ }^{6-9}$ Instead, we decided to focus on trying to develop method for constucting the crutial $\beta$-linked glycosidic bond between the fully constructed trisaccharide and the aglycon.

Scheme 12: Retrosynthetic analysis for vineomycin C

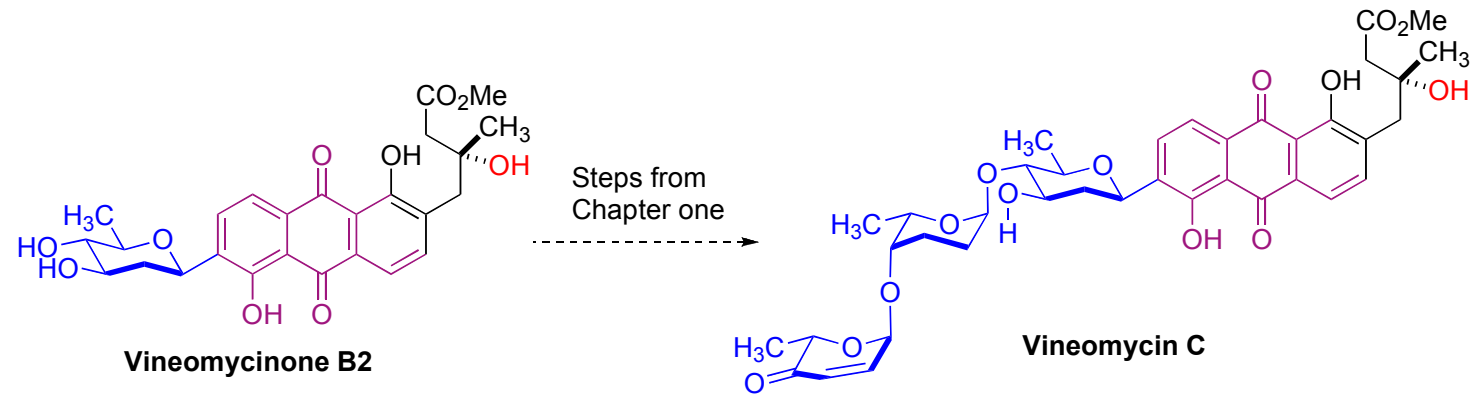

This approach, if successful, in addition to being more efficienet due to convergency, would also be more amenable for the synthesis of a larger range of natural products from this family (e.g., both Vineomycin C and PI-080). ${ }^{10,11}$ As outlined in Scheme 13, we envisioned direct coupling of the Vineomycin C/PI-080 trisaccharide 21 with an anomeric leaving group, 
with a suitably protected aglycon 22. We imagined this step would be promoted by a Lewis acid. The exact nature of the right Lewis acid and protecting groups would need to be explored, but there were significant precedents from the syntheses of Vineomycinone B2 methyl ester that we thought we could build upon. 6,9

Scheme 13: Retrosynthetic analysis for vineomycin $C$

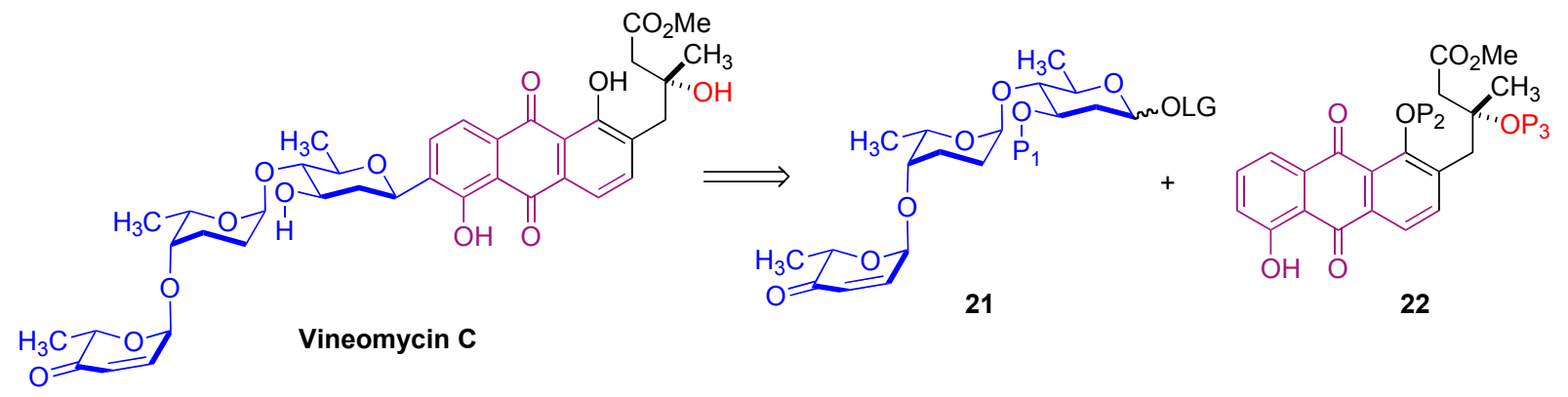

By a related route, the syntheses of more complicated angucycline structures could also be accomplished (Schemes 14 and 15). Our synthesis of PI-080 was imagined as being completed by an annulation of the napthalene trisaccharide $\mathbf{2 3}$ with $\mathbf{2 4}$. In turn, $\mathbf{2 3}$ was envisioned as coming from the above described convergent glycosylation between trisaccharide 25 and napthalene 26. Similalry, the slightly simplers angucycline natural products SCH-47554 and $\mathrm{SCH}-47555^{24}$ could be derived by an annulative coupling of the napthalene disaccharide 27 with 24, where once again the disaccharide $\mathbf{2 7}$ was seen as coming from a Lewis acid mediated coupling between $\mathbf{2 6}$ and a disacchairde 28. Recently a route to a molecule similar to disaccharide 27 was reported by Barrett. ${ }^{25}$ The Barrett route prepared its disaccharide in 21 total steps from D-glucose and L-rhamnose. Thus as a goal we set out to try to prepare a similar disaccharide to 27 via our de novo methodology in significantly less steps from 2-acylfuran. 
Scheme 14: Retrosynthetic analysis for PI-080
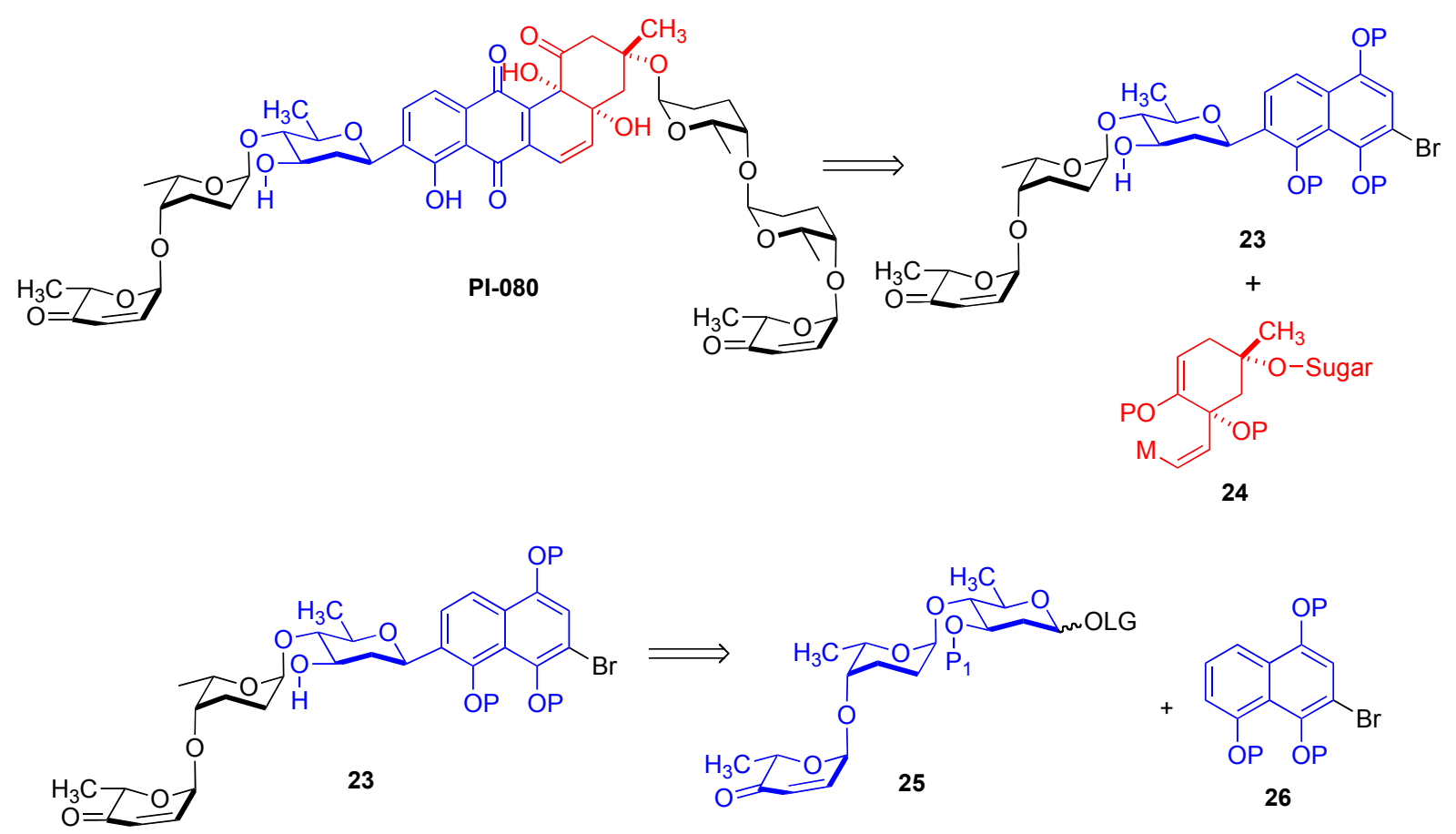

24

For simplicity sake, we decided to focus our methodology on the development of this latter coupling reaction between $\mathbf{2 6}$ and $\mathbf{2 8}$ (Scheme 15). Because we already had access to trisaccharide 19, the investigation of the coupling between 25 and 26 was also planned. In addition to the development of a new more convergent coupling strategy, it was also imagined that materials from these studies would lead to important SAR studies of the biological activity of the vineomycin and PI-080 type natural products. 
Scheme 15: Retrosynthetic analysis for SCH-47554 and SCH-7555
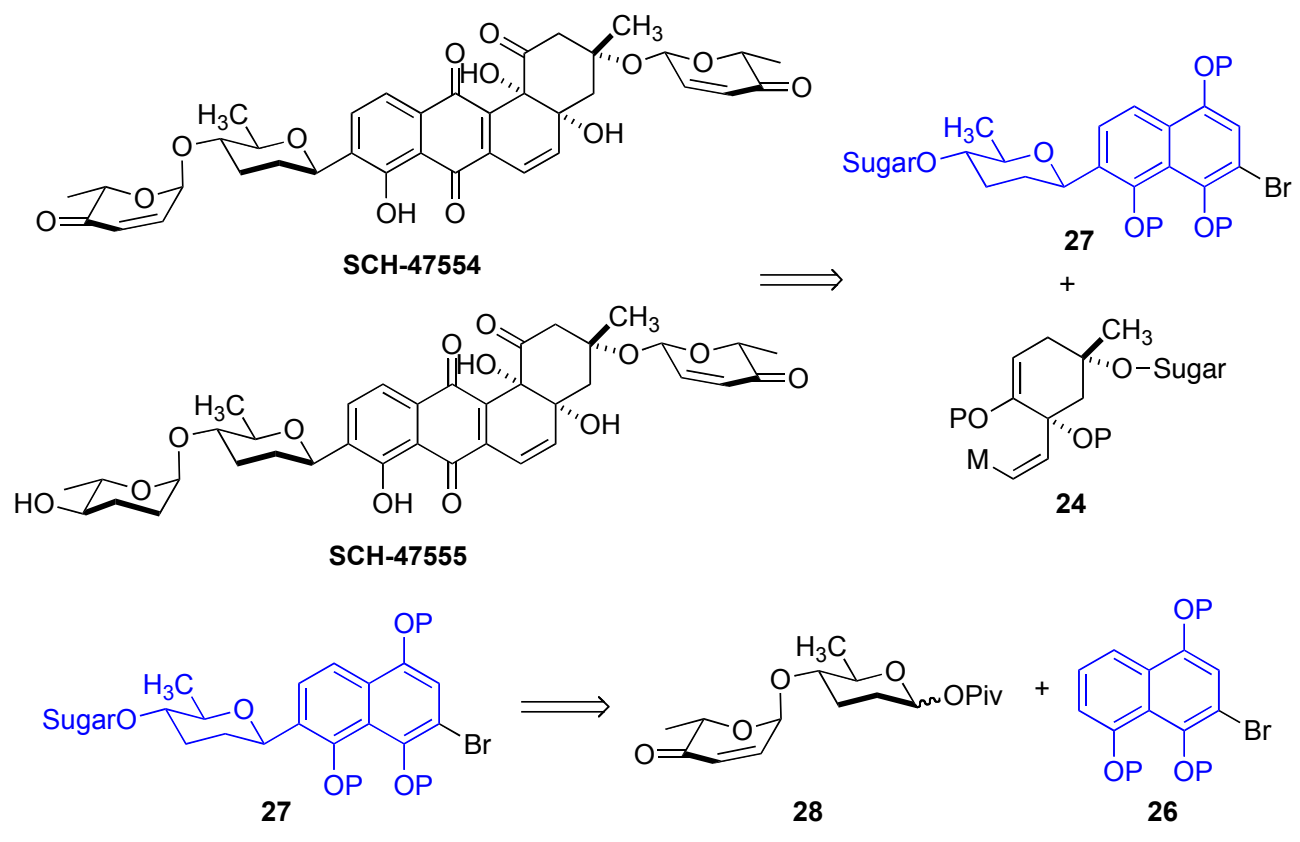

Our first synthetic target became the known bromonapthalene 33, which we hoped can be prepared by a benzyne Diels-Alder reaction/acid catalyzed ring opening reaction sequence (Scheme 16). ${ }^{25_{26}}$ While 33 was known in the literature, the literature synthesis was reported to occur via an unselective bromination of juvalone. ${ }^{27}$

Scheme 16: Synthesis of key Bromoanthracene coupling partner

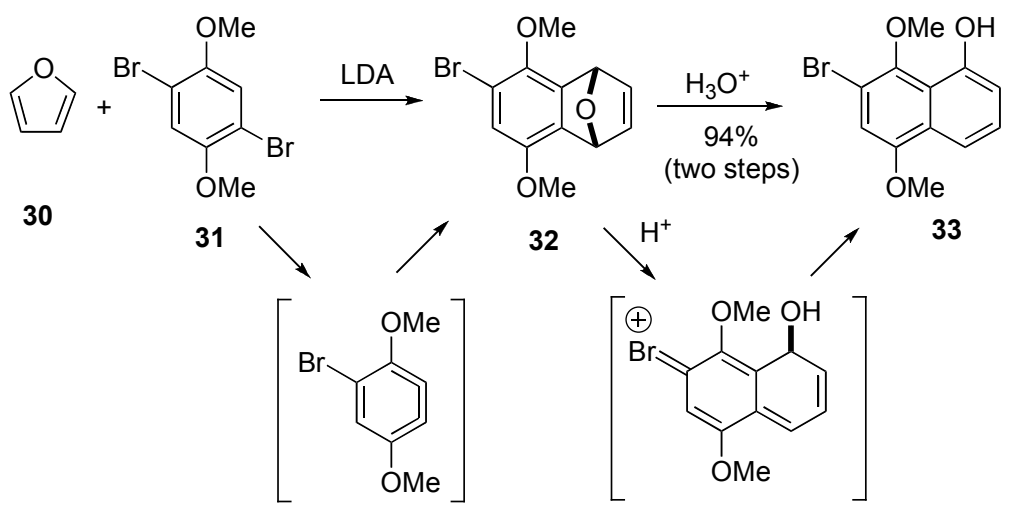


We decided to explore the route outlined in Scheme 16. This was accomplished by treating 2,5-dibromo-1,4-dimethoxybenzene 31 with LDA followed by furan at $-78{ }^{\circ} \mathrm{C}$, which led to the formation of Diels-Alder adduct $\mathbf{3 2}$ in a near quantitative. Acid-catalyzed rearrangement of 32 cleanly gave 33 in an excellent yield (94\%). Key to the success of this strategy was the ability of the bromine atom to direct the furan ring opening reaction. There had been precedent in the literature of methoxy-groups and fluorides but not bromines.

Scheme 17: Synthesis of the D-amiceto-sugar of the desired disaccharide 38

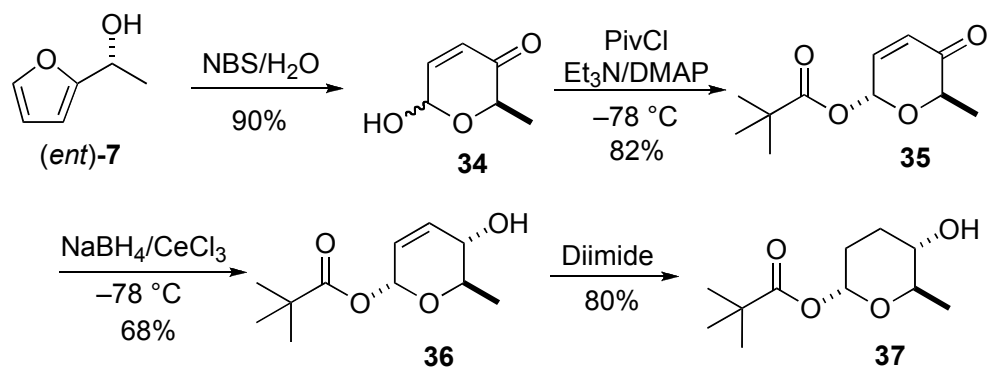

We next turned to the synthesis of the desired D,L-disaccharide 38, with a pivaloate ester as the anomeric leaving group (Scheme 17). We initially looked into using a $t$-butyl carbonate as the anomeric leaving group but it proved to be too unstable. Because we were concerned about the potential instablilty of the pyranone ring system to the proposed Lewis acid $\beta$ - $C$-glycoside forming conditions, we also planned on making the allylic acetate 39, which in turn can be deprotected and oxidized to the pyranone.

The syntheis of $\mathbf{3 8}$ began with the synthesis of $\alpha$-pyranone 35 . As before, the Achmatowicz oxidation of (ent)-7 formed hemi-acetal 34 as a mixture of diastereomers (Scheme 17), which was diastereoselectively acylated with pivalolyl chloride to give $\mathbf{3 5}$ ( $82 \%$ yield). 
Luche reduction $\left(\mathrm{NaBH}_{4} / \mathrm{CeCl}_{3}\right)$ of pyranone 35 diastereoselectiely gave allylic alcohol $\mathbf{3 6}(68 \%$ yield), which was followed by a diimide reduction (excess $\mathrm{NBSH} / \mathrm{Et}_{3} \mathrm{~N}$ ) of the pyran double bond to give $37(80 \%)$. Our investigation into a cobalt catalyzed one-pot concomiant 1,4-/1,2reduction of the enone of $\mathbf{3 5}$ to the equatorial alcohol of $\mathbf{3 7}$ led only to decompisition.

Scheme 18: Synthesis of the D,L-disaccharides 38 and 39

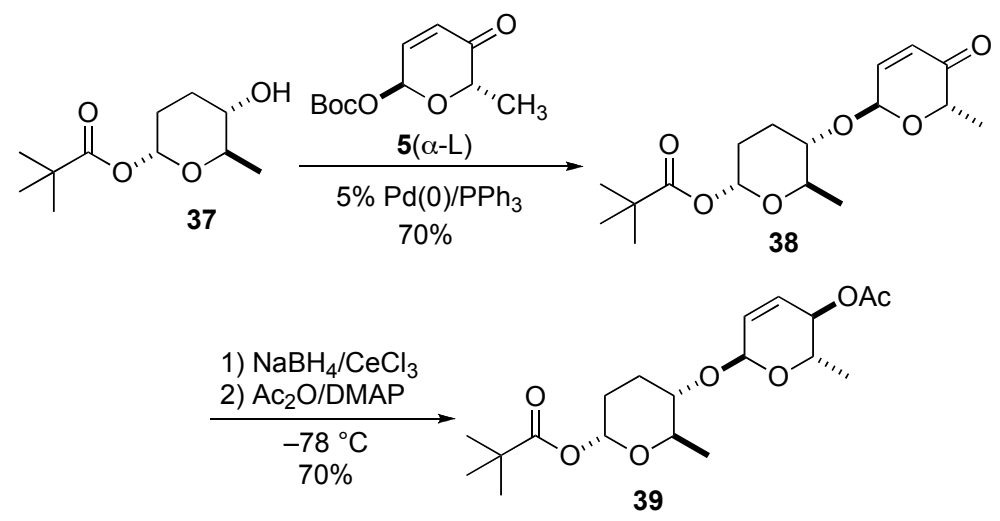

We returned to the palladium glycosylation condition to install the L-sugar of the desired disaccharides 38 and 39 (Scheme 18). Exposure of $\mathbf{3 7}$ to a slight excess of Boc-pyraone 5( $\alpha-\mathbf{L})$ and Pd-catalysis $\left(2.5 \% \mathrm{Pd}_{2}(\mathrm{dba}) \cdot \mathrm{CHCl}_{3} / 10 \% \mathrm{PPh}_{3}\right)$ gave good yield of $\mathbf{3 8}$ (70\% yield). Finally, another Luche reduction $\left(\mathrm{NaBH}_{4} / \mathrm{CeCl}_{3}\right)$ of pyranone $\mathbf{3 8}$ followed by acylation $\left(\mathrm{Ac}_{2} \mathrm{O} / \mathrm{DMAP}\right)$ gave the backup disaccharide $\mathbf{3 9}$ in $70 \%$ for the two steps. 
Scheme 19: Attempted Lewis coupling of $\mathbf{3 8}$ and $\mathbf{3 9}$ with 33
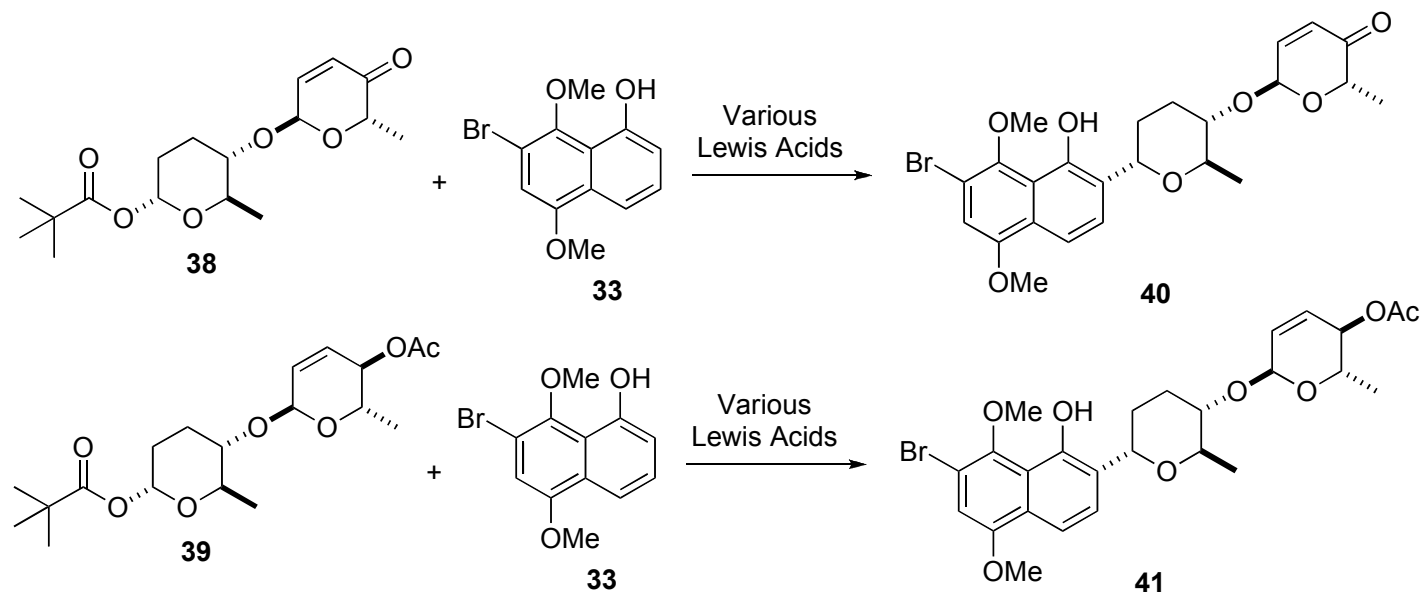

With the model napthanol $\mathbf{3 3}$ and the two D,L-diassacharides $\mathbf{3 8}$ and $\mathbf{3 9}$ in hand, we explored the use of various Lewis acid $\left(\mathrm{TiCl}_{4}, \mathrm{Ti}(\mathrm{Oi}-\mathrm{Pr})_{4}, \mathrm{SiCl}_{4}, \mathrm{BF}_{3}\right.$, and TMSOTf) to promote coupling (Scheme 19). Unfortuantley, all the Lewis acids used for the coupling of $\mathbf{3 3}$ and the D,L-diassacharides $\mathbf{3 8}$ led to decomposition of the disaccharide 38. Similarly, when the D,Ldiassacharides 39 was used, the only coupling products detected were of mono-saccharides with 33.

Despite these frustrations, we decided to go ahead and explore the coupling of $\mathbf{3 3}$ with the vineomycin trisaccharide 19 (Scheme 20). In an attempt to address the problems associated with the instability of the glycosidic bonds to the harsh Lewis acid conditions that are required for the coupling reactions, we decided to first preassociate the two coupling partners via an $O$ glycoside bond (44) and persue condition for migration of the trisaccharide from oxygen to carbon (44 to $\mathbf{4 5}$ ), which we hoped would allow for the use of milder Lewis acids. 
Scheme 20: Synthesis of the vineomycin C/PI-080 trisaccharide 43 coupling partner

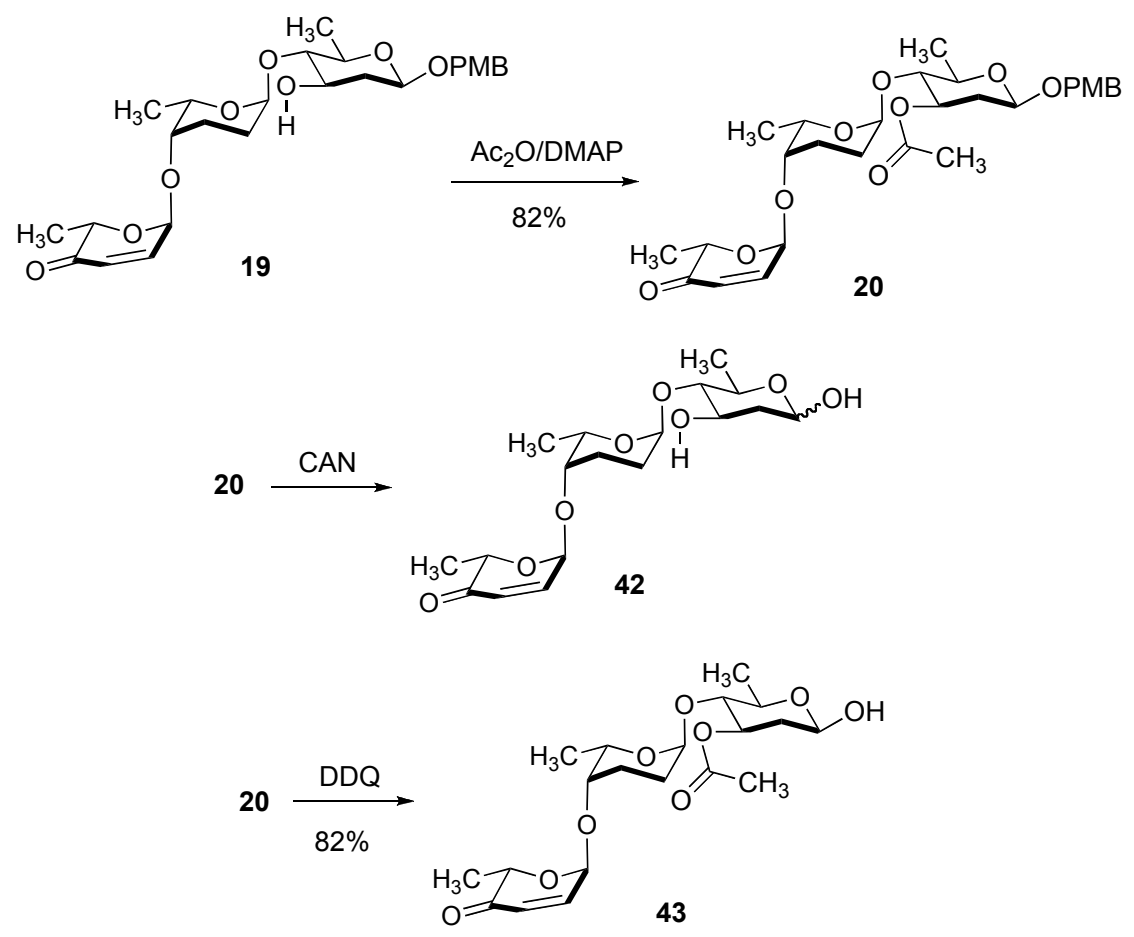

To prepare the trisaccharide 19 for the coupling reaction, we first protected the $C-3$ olivose sugar alcohol as an acetate and deprotected the $C-1$ OPMB group. This was accomplished by using acetic anhydride and DMAP to give $\mathbf{2 0}(82 \%)$. To our surprise the deprotection of the anomeric PMB group with ceric ammonium nitrate occurred with conconiment acetate deprotection. Fortuantely, this problem was easily solved by switching to DDQ condition. These modified conditions led to clean conversion of 20 to $43(82 \%)$ as a mixture of anomeric isomers.

With 43 in hand, we turned our attention to its coupling with $\mathbf{3 3}$ to initially form the $O$ glycoside 44, and eventually its conversion to the desired $C$-glycoside $45{ }^{28}$ The efforts to assemble the bond began with the attempts to in situ convert the anomeric alcohol to a good 
leaving group (tosylate) followed by an $\mathrm{S}_{\mathrm{N}} 2$ type displacement with the phenoxide anion from $\mathbf{3 3}$. While we attempted with several bases $\left(\mathrm{Py}, \mathrm{Et}_{3} \mathrm{~N}, \mathrm{NaH}, \mathrm{KO} t \mathrm{Bu}\right)$, unfortunately no desired product was detected. In contrast, the desired $O$-glycoside $\mathbf{4 4}$ was formed as a mixture of anomeric diastereomers in good yield when we turned to typical Mitsunobu conditions $\left(\mathrm{PPh}_{3} / \mathrm{DIAD}\right)$. Unfortunately, all attempts to use Lewis acids to isomerize the $O$-glycoside 44 into the desire $\beta$-link $C$-glycoside led to either no reaction or decompostion of 44 .

Scheme 21: Attempted coupling of 33 with 43
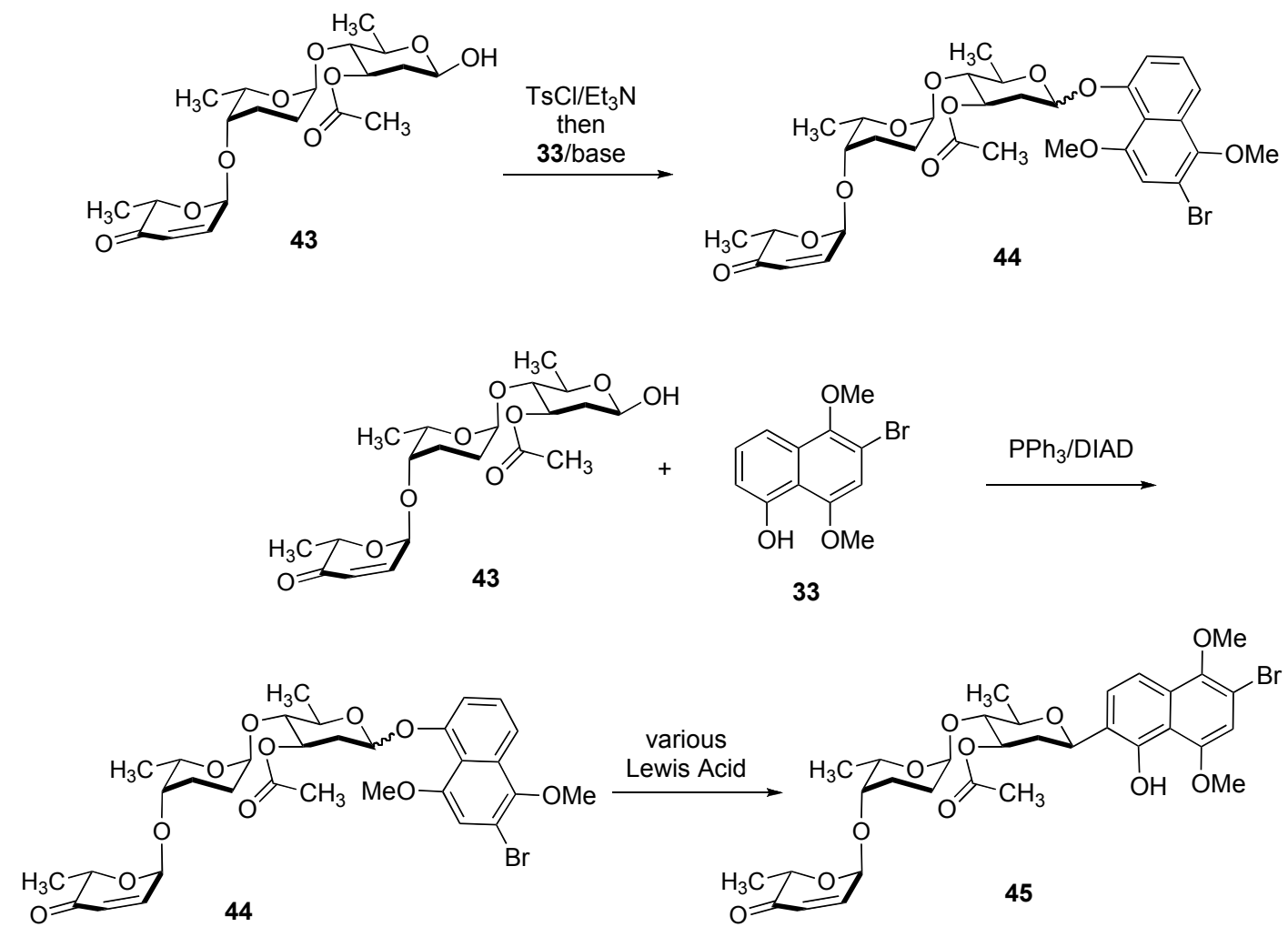

In conclusion, a new synthesis of the disaccharide portion of the $C$-aryl glycoside natural products SCH-47554 and SCH-47555 was accomplished. In addition, two methods were explored for the Lewis acid directed formation of $\beta$-linked $C$-aryl di- and tri-saccharides. The 
first was the direct Lewic acid coupling and the second was the Lewis acid promoted migration of $O$ - to $C$-glycosides. Unfortunately neither method led to the desired product. It is worth noting that if we were successful in our coupling stragy to make disaccharide $\mathbf{4 0}$ we would have achieve our goal to beat the Barrett route by 11 steps ( 10 vs 21 total steps). Future efforts will focus on the use of other aromatic rings in the Lewis acid promoted migration of $O$ - to $C$ glycosides. 


\section{Chapter III. Attempted Synthesis of Glycosylated Poly-Aromatic Natural Products}

In contrast to the focus of the previous chapters, the focus of this chapter is the development of a new method for installing natural and unnatural sugars onto known polyaromatic natural products. In the previous chapters, we demonstrated that the sugar portion of glycosylated natural products can also be part of the natural product's pharmacophore, as opposed to a water solubility enhancer. Returning to this previously believed mantra, we imagined installing sugars onto relatively insoluble natural products to improve its solubility. In addition, we hoped that this would improve the overall activity. The biologically active natural products we chose for these efforts were ellipticines ${ }^{29}$ and camptothecins ${ }^{30}$ (Figure 10).

Figure 10: Ellipticine and related compounds

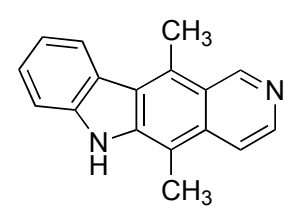

Ellipticine

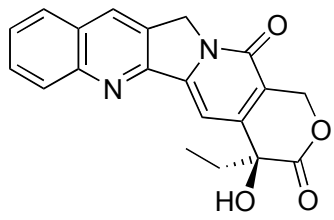

camptothecin

Both ellipticines and camptothecins are angular, albeit flat poly-aromatic alkaloids that contain a pyridine ring. ${ }^{3132}$ The structural similarity also shows up in their biological mechanism of action. Both natural products intercalate into DNA and have basic groups that hydrogen bond to DNA. This DNA binding causes the inhibition of the DNA-repair enzymes, topoisomerase I or topoisomerase II. ${ }^{29,30_{33}}$ Inhibition of topoisomerase I and topoisomerase II has been linked to selective toxicity to various cancer cells, and could possibly lead to a new treatment for cancer. 
While neither ellipticine nor camptothecin has become an approved drug, two related camptothecins (topotecan and irinotecan, Figure 12) have been approved for use as cancer chemotherapeutics. ${ }^{29,30}$ For our first foray into the synthesis of glycosylated variants of these types of natural products, we decided to look into the synthesis of glycosylated ellipticines because of the overall simpler structure. These glycosylation studies required the preparation of various hydroxy-substituted aza-ellipticines. ${ }^{34}$

Figure 11: Ellipticine and related compounds

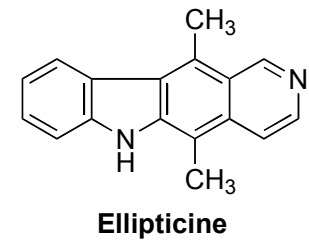

Ellipticine

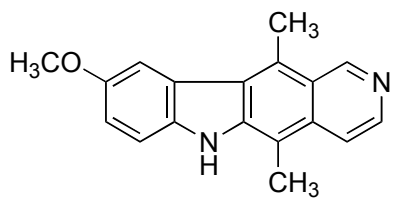

9-Methoxy-ellipticine

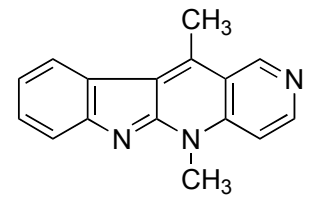

5-Aza-ellipticine

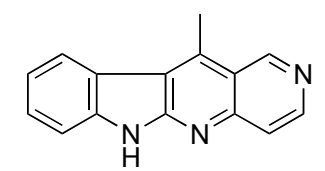

5-Aza-desmethyl-ellipticine

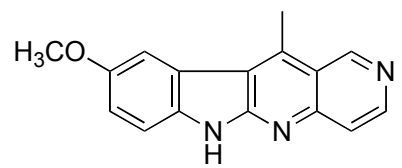

9-Methoxy-5-aza-desmethyl-ellipticine

Ellipticine (5,11-Dimethyl-6H-pyrido[4,3-b]carbazole) is a tetracyclic indole/pyridine containing natural product that has attracted significant attention for its potential as an antineoplastic agent. ${ }^{35}$ Structurally related natural products, like 9-methoxy-ellipticine ${ }^{33}$ and 5aza-ellipticine, ${ }^{36}$ have also been isolated and show significant anti-cancer activities (Figure 11). The mode of action for the ellipticines has been found to occur by binding to the DNA repair enzyme topoisomerase II. Unfortunately, issues associated with overall toxicity have limited the interest in the use of these natural products as drugs. That being stated, significant interest in synthesizing and testing of analogue structures of ellipticine still remains active. In this regard, 
we felt that glycosylated ellipticines, in addition to having better water solubility (lowering it effective dose), may lead to selective uptake by cancer cells.

Scheme 22: The Wang cyclization approach to ellipticine

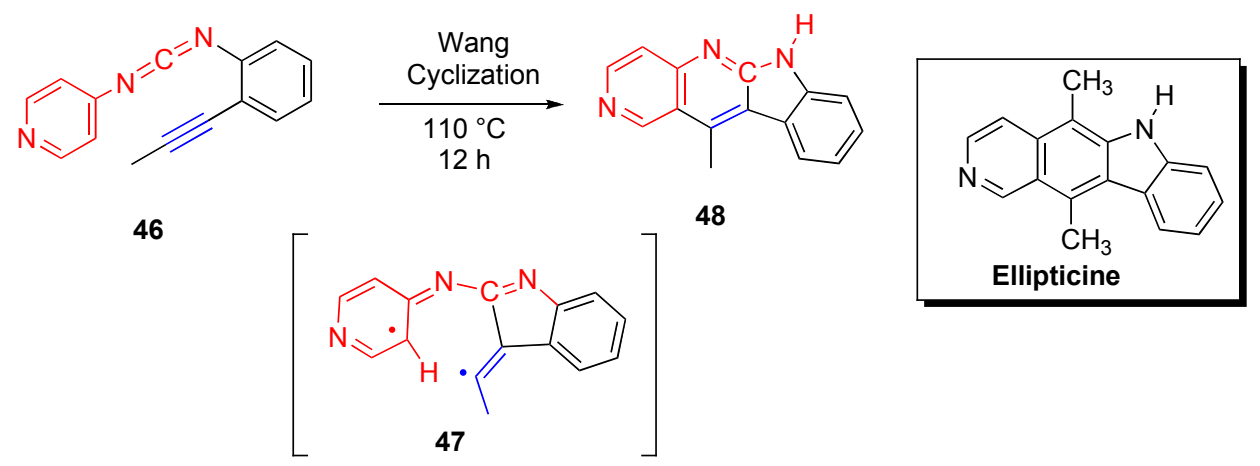

In a similar effort to prepare more active ellipticine analogues, the Wang group has developed a route to related 5-aza-ellipticines (Scheme 22). ${ }^{37}$ This route utilizes a Wang or bisaza-Schmittel type cyclization (46 to 48$)^{38}, 39$ to establish the aza-ellipticine ring system. The Wang approach to the ellipticine replaces the allene portion of the Schmittel substrate with a carbodiimide functional group, and is believed to occur via a bi-radical intermediate, like 47. We decided to use this approach to prepare aza-ellipticine substrates for glycosylation. 
Scheme 23: Hydroxylated 5-aza-ellipticines for potential glycosylation

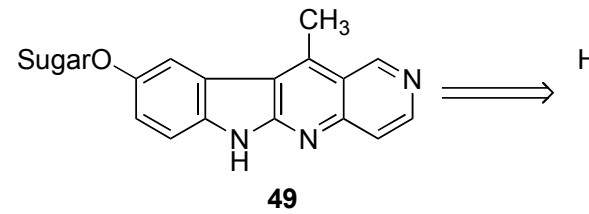<smiles></smiles>
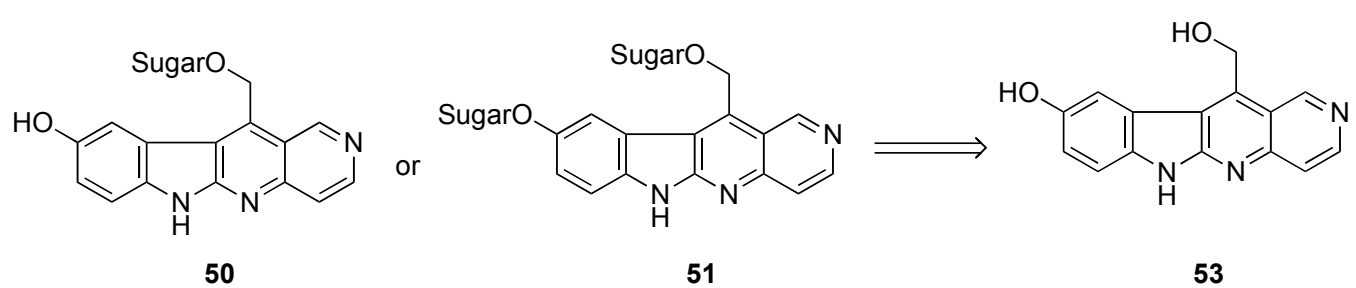

To allow for glycosylation, we need access to aza-elipticines substituted with hydroxyl group. To maximize the range of reactivity in the glycosylation reaction, we planned to install both phenolic and benzylic hydroxyl groups. We desired aza-ellipticines $\mathbf{5 2}$ and $\mathbf{5 3}$ for our glycosylation studies and targeted their syntheses with the appropriate protecting groups (Scheme 23). Our retrosynthetic plan for the target molecule 54, with $\mathrm{R}_{1}$ being a protected phenol and $R_{2}$ being either a hydrogen or a protected alcohol, is outlined in Scheme 24. We chose to use a benzyl ether and a trialkyl silyl ether as orthogonal protecting groups. Because we were more confident with the stability of the benzyl ether to the thermal conditions of the Wang cyclization, we chose to make aza-ellipticines with $\mathrm{R}_{1}=\mathrm{BnO}$ and $\mathrm{R}_{2}=\mathrm{H}$ or $\mathrm{R}_{3} \mathrm{SiO}(\mathbf{5 4}$, Scheme 24). 
Scheme 24: Retrosynthesis for a Hydroxylated aza-ellipticines

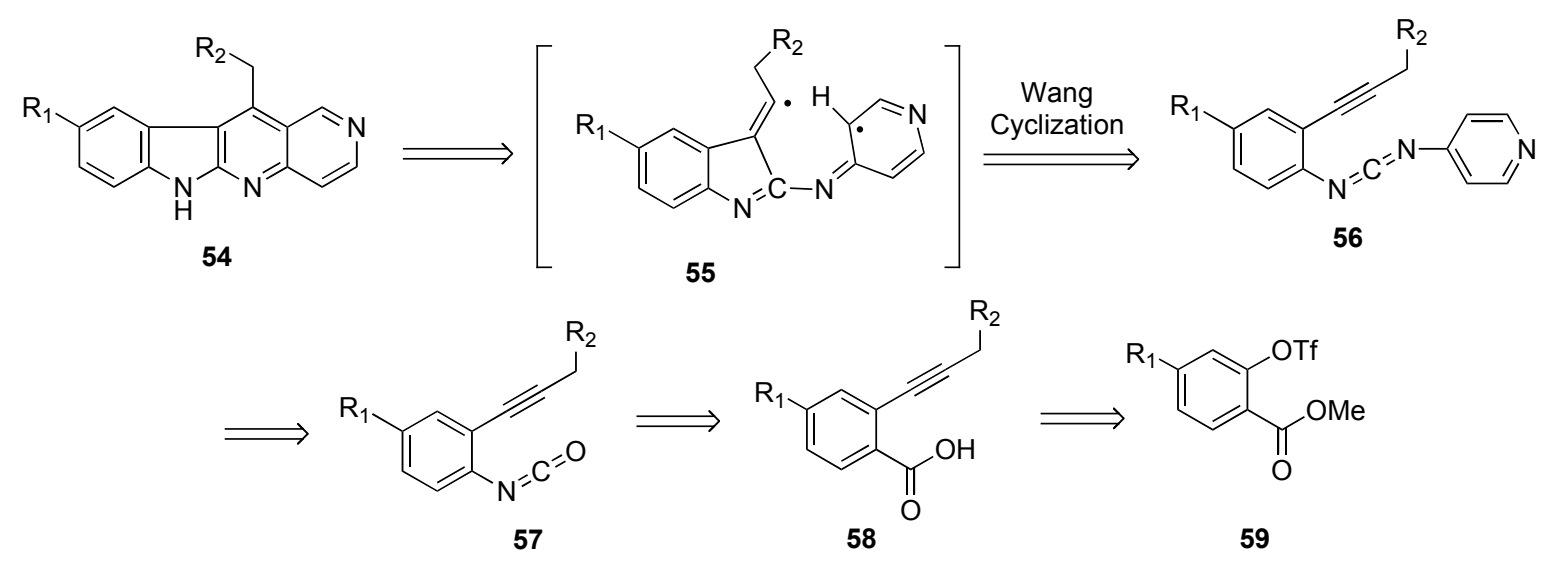

Our first effort to prepare a hydroxylated aza-ellipticine is outlined in Scheme 25 and was based on a route previously developed by Quan Zhang, Chongsheng Shi, Hai-Ren Zhang, and Prof. Wang. ${ }^{37}$ The synthesis began with protection of the more reactive C-4 phenol in commercially available methyl 2,4-dihydroxybenzoate 60. Using the Williamson ether conditions $\left(\mathrm{K}_{2} \mathrm{CO}_{3} / \mathrm{BnBr}\right)$, the $C-4$ phenol was converted to the benzyl ether $\mathbf{6 1}$ in an $86 \%$ yield. The remaining $C-2$ phenol was converted into the aryltriflate 62 with $\mathrm{Tf}_{2} \mathrm{O} / \mathrm{Py}$ in near quantitative yield. Sonogashira coupling of triflate $\mathbf{6 2}$ with excess propyne gave $\mathbf{6 3}$ in good yield. Base-catalyzed hydrolysis of the methyl ester 63 gave the desired carboxylic acid $\mathbf{6 4}$ after acidification. It should be noted that the ester hydrolysis reaction needed to be carefully monitored because of a competing alkyne hydrolysis reaction giving ketone $\mathbf{6 5}$, which at times could be quite significant. The optimal reaction condition was to carefully monitor the reaction by TLC and to quench the reaction at the first sign of ketone formation. 
Scheme 25: Synthesis of the key alkynyl acid

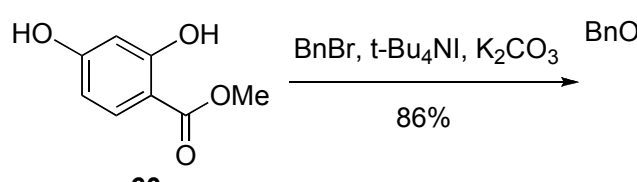

60

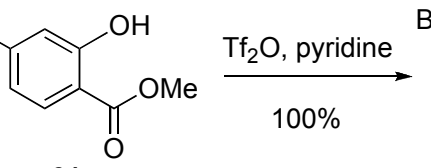

61<smiles>CCOc1cc(O[GaH2])ccc1C(=O)OC</smiles>

62
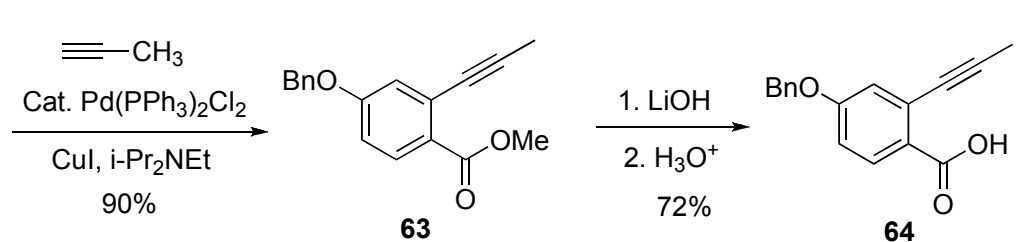<smiles>CC(=O)Cc1cc(O[18F])ccc1C(=O)O</smiles>

With the alkynyl acid $\mathbf{6 4}$ in hand, we next looked into the conversion of it to isocyanate 67 via Curtius rearrangement (Scheme 26). Exposure of carboxylic acid 64 to phosphoryl azide 66 cleanly gave 67 in good yields without the use of silica gel chromatography. It should be noted that using $\mathrm{pH} 7$ water in the aqueous work up of the reaction is important to prevent hydrolysis of the acyl azide 67 back to the carboxylic acid 64. Finally, thermolysis of the acyl azide 67 in refluxing toluene cleanly gave isocyanate 68 , which in turn could be used without further purification.

Scheme 26: Synthesis of the key isocyanate

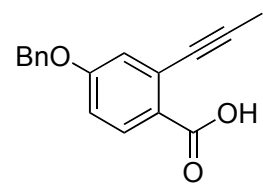

64

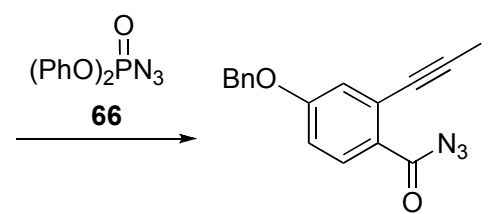

67

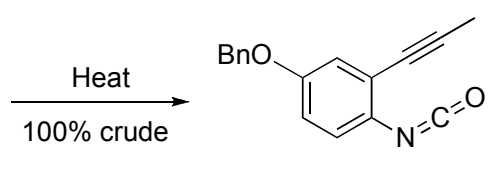

68 
Finally, the isocyanate $\mathbf{6 8}$ was converted into the desired 9-benzyloxy-5-aza-ellipticine $\mathbf{7 1}$ via the Wang cyclization (Scheme 27). Isocyanate $\mathbf{6 8}$ was treated with freshly prepared phosphoryl imine $69 .{ }^{40}$ After the evidence of carbodiimide 70 formation was indicated by TLC, the reaction was heated at $138{ }^{\circ} \mathrm{C}$ for $15 \mathrm{~h}$ to give the desired aza-ellipticine 71 in $25 \%$ overall yield. Pure aza-ellipticine $\mathbf{7 1}$ was isolated by a cumbersome extraction/precipitation sequence, instead of silica gel chromatography, due to its poor solubility.

Scheme 27: Synthesis of a Hydroxylated aza-ellipticines

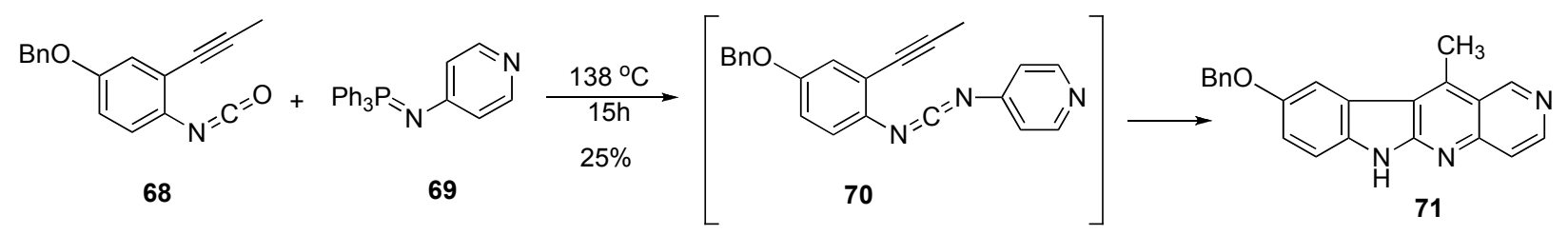

The final hydrogenolysis deprotection of benzyl-protected hydroxy-aza-ellipticine failed in many solvents (Scheme 28). The same solubility problem that made the purification of $\mathbf{7 1}$ quite difficult also limited our ability to further functionalize 71. Ellipticine 71 was only soluble in polar protic solvent like acidic acid. In fact, the hydrogenolysis of $\mathbf{7 1}$ in acetic acid may have worked. The starting material disappeared by TLC, but no recognizable products were isolated from the reaction. This may have been due to the limited solubility of the product, but also potentially due to the instability of the product 72 (i.e., oxidation of the phenol $\mathbf{7 2}$ to an azaquinone). Thus, we desired an alternative route to different aza-ellipticine. 
Scheme 28: Attempted deprotection of the benzyl ether
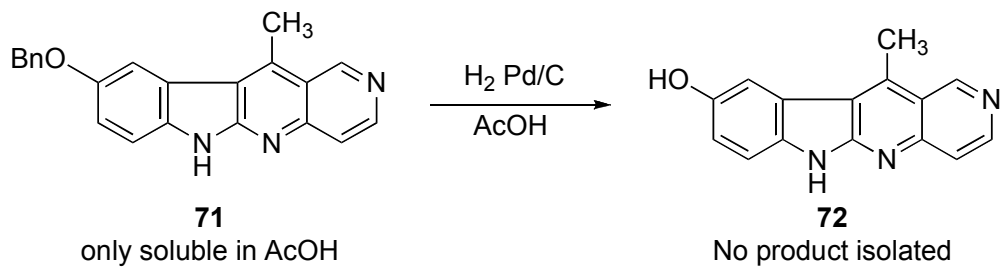

Our next route envisioned the installation of a TBS-protected benzylic alcohol for eventual glycosylation. The addition of this large lipophilic functional group may also improve the solubility of the product. Once again, this route ran into problems with protecting group chemistry. In particular, problems were experienced with the instability of a TBS-group during the ester hydrolysis step. Later on in this chapter, a similar problem was encountered with a TIPS-group falling off during a Wang cyclization (Scheme 30).

This revised route returned to the Sonogashira coupling of triflate 62, but now with TBSprotected propargyl alcohol instead of propyne (Scheme 29). While a Sonogashira reaction worked to give an $81 \%$ yield of the desired alkynyl ester $\mathbf{7 4}$, all our attempts to hydrolysis the methyl ester $\mathbf{7 4}$ occurred with concomitant hydrolysis of the TBS-ether.

Scheme 29: Synthesis of a Hydroxylated aza-ellipticines

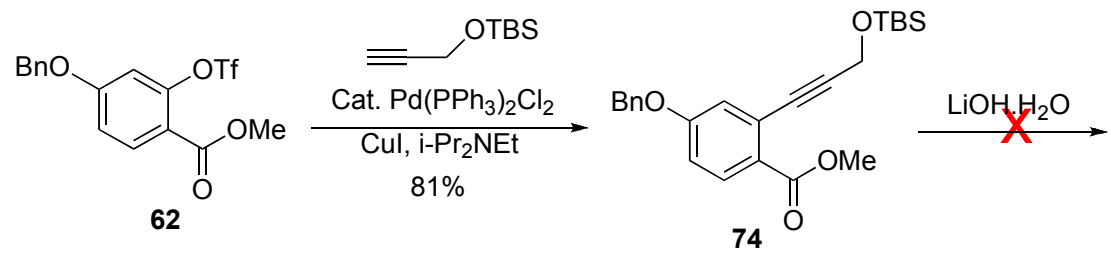

Thus, we decided to switch to the bulkier TIPS-protecting group (Scheme 30). Although 
the Sonogashira coupling between triflate 62 and TIPS-protected propargyl alcohol failed, we were able to couple the triflate $\mathbf{6 2}$ with the unprotected propargyl alcohol to give $\mathbf{7 5}$ in good overall yield, which then was protected with TIPS-chloride in near quantitative yield to give TIPS-ether 76.

Scheme 30: Synthesis of a Hydroxylated aza-ellipticines
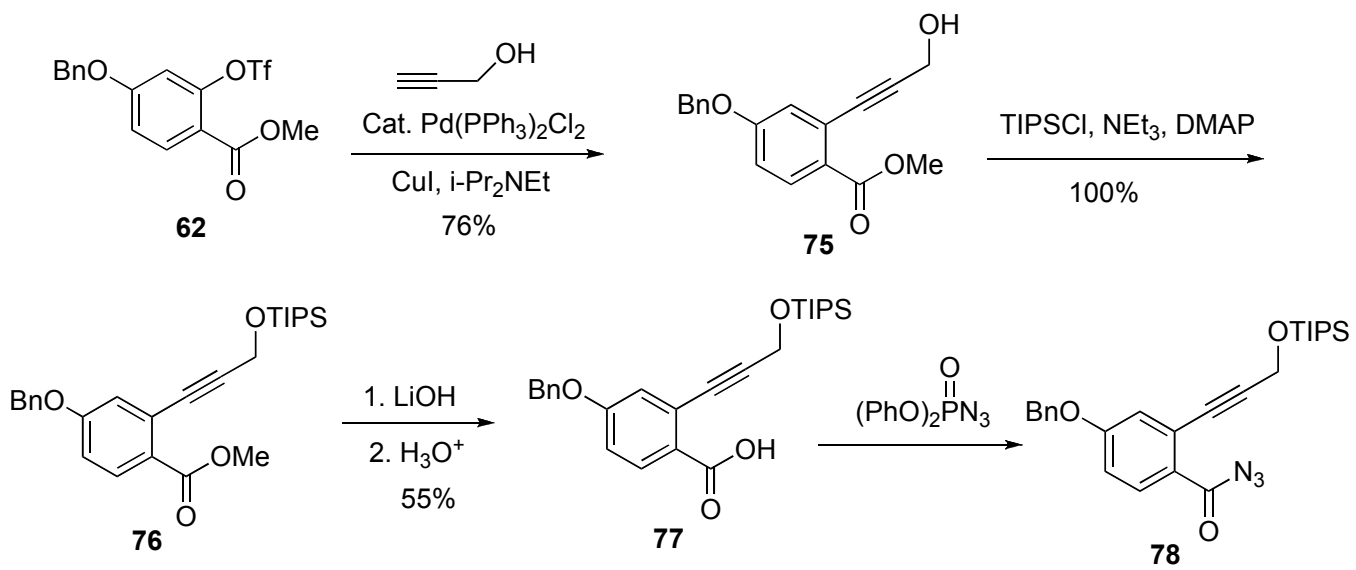

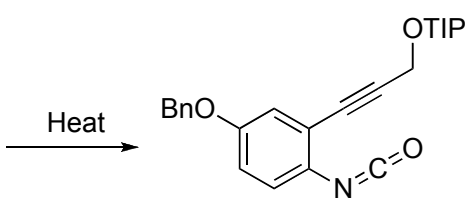

79

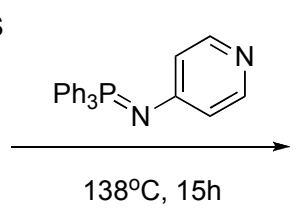

$138^{\circ} \mathrm{C}, 15 \mathrm{~h}$

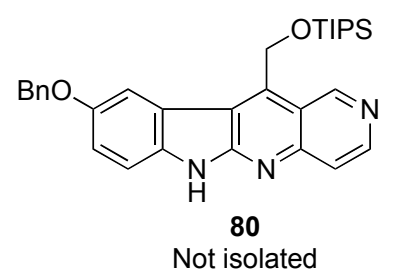

Now with the TIPS group in place (Scheme 30), we were able to selectively hydrolyze the methyl ester $\mathbf{7 6}$ with $\mathrm{LiOH}$ and isolate the carboxylic acid 77 in 55\% yield after acidification. As before, we were able to convert the carboxylic acid 77 to the acylazide $\mathbf{7 8}$ with the phosphoryl azide reagent. Similarly thermolysis of acyl azide $\mathbf{7 8}$ cleanly gave isocyanate $\mathbf{7 9}$ in good yield. However, the reaction failed when we preformed the typical Wang cyclization procedure on isocyanate 79 . When we treated isocyanate 79 with the phosphoryl imide 69 reagent until a new spot appeared, and then heated the reaction mixture to $138{ }^{\circ} \mathrm{C}$ for several 
hours, we were not able to isolate any product that looked like the desired aza-ellipticine $\mathbf{8 0}$. Only TIPSOH was detected, which led us to believe that the TIPS ether was falling apart under these high temperatures.

These difficulties associate with the poor solubility of the aza-ellipticines convinced us to switch our starting natural product of focus to the camptothecins. We chose the camptothecins because they share many similar features with the ellipticines. These similarities include: 1) both are poly-aromatic anti-cancer agent, 2) both cytotoxicities result from the inhibition of topoisomerase (I and II), and 3) both potential as a drug candidate suffer from poor solubility. Evidence in the literature suggests that camptothecins display a slightly better solubility profile in aprotic solvents. It should be noted that much of this evidence was collected from the patent literature, which more often than not, did not report experimental procedures and/or spectral data.

Figure 12: Camptothecin and related structures

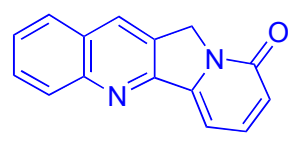

camptothecin ring system<smiles>CCc1c2c(nc3ccc(O)cc13)-c1cc3c(c(=O)n1C2)COC(=O)[C@@]3(O)CC</smiles>

SN-38

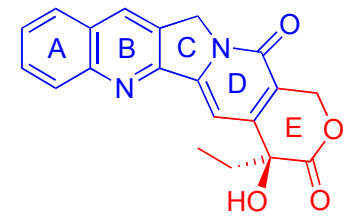

camptothecin

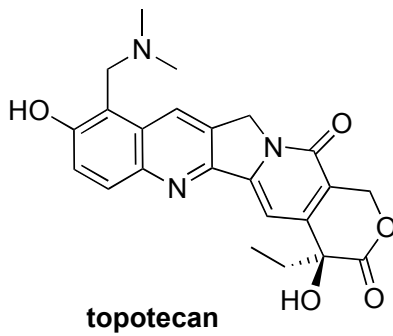

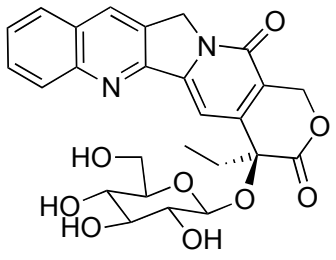

gluco-camptothecin

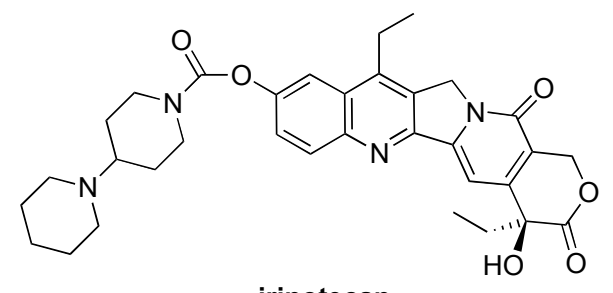

irinotecan 
Camptothecin is a naturally occurring highly conjugated polycyclic quinoline that has been attracting a tremendous amount of attention from both the academia and the pharmaceutical industry. ${ }^{41}$ Since its initial isolation in 1966 from the Chinese plant Camptotheca acuminata, ${ }^{42}$ the alkaloid has shown excellent antitumor activity. In fact, several camptothecin analogues are being used clinically for treatment of various cancers (Figure 12). ${ }^{43}$

It is worth noting that in the 1970s camptothecin was entered into clinical trials in the form of its water-soluble sodium salt of the hydrolyzed ester; however, the trials failed and the interest in camptothecin subsided. Revived interest in camptothecin came from the discovery of its mechanism of action. ${ }^{44}$ In the late 1980s, it was discovered that camptothecin interacts with DNA topoisomerase I, an enzyme that is essential for DNA replication. ${ }^{45}$ The topoisomerases are enzymes that catalyze the topo-isomerization reactions (relaxation/supercoiling, knotting/unknotting and catenation/decatenation) of DNA. ${ }^{46}$ In fact, the structure of the cleavable ternary complex is of great interest for the elucidation of the mechanism of action and development of new topoisomerase inhibitors. The discovery of topoisomerases as new targets for cancer chemotherapy and the mechanism of action of camptothecin put camptothecin back on the frontlines of anticancer drug development. ${ }^{47}$ As the result of these renewed efforts, two FDA approved drugs have appeared on the market topotecan (ovarian cancer and small-cell lung cancer) and irinotecan (colorectal cancer) ${ }^{48}$

Besides ongoing studies on topotecan and irinotecan, significant effort has also been spent on the development of new anticancer drugs from this family, with a particular effort towards producing compounds with better solubility and tissue-targeting properties. ${ }^{49}$ To these ends, we proposed to take advantage of the inherent water solubility of carbohydrates, along with 
the fact that they are actively transported across cell membranes to make new carbohydratelinked camptothecin analogues. It should be noted that the problems associated with the use of camptothecins are primarily related to its poor solubility in both organic solvents and water.

\section{Scheme 31: The Wang approach to camptothecin}

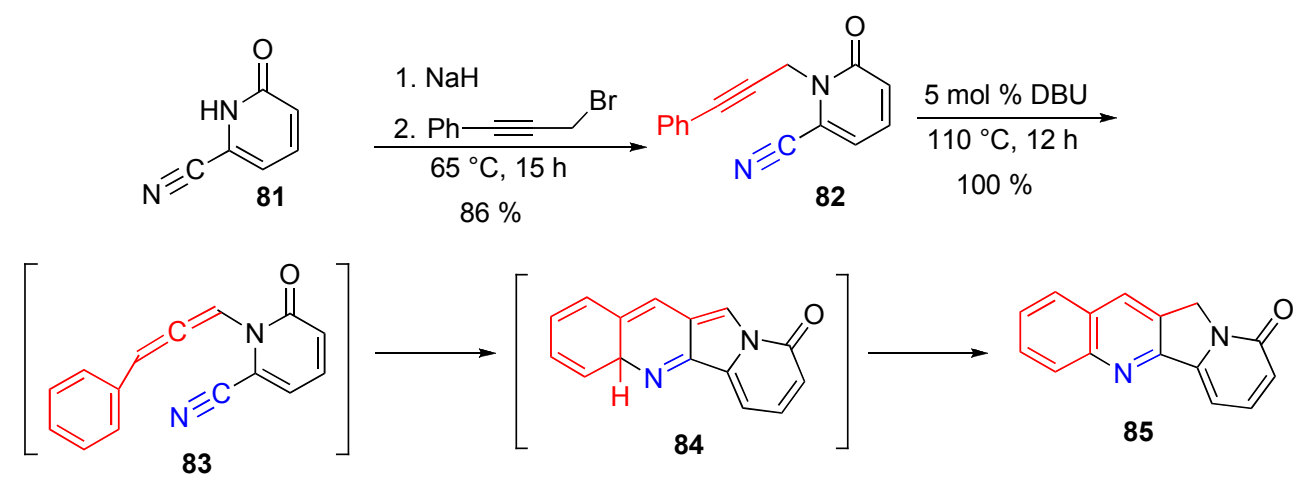

More recently, the Wang group developed a new synthetic pathway to the camptothecin ABCD ring system (Scheme 31). ${ }^{50}$ The Wang approach begins with the $N$-alkylation of 1,6dihydro-6-oxo-2-pyridinecarbonitrile $\mathbf{8 1}$ to provide $\mathbf{8 2}$. Treatment of $\mathbf{8 2}$ with a catalytic amount of DBU ( $5 \mathrm{~mol} \%)$ at $110{ }^{\circ} \mathrm{C}$ for 12 hours produced the desired $\mathrm{ABCD}$ ring core of camptothecin 85. Key to the Wang approach is the recognition that a base-catalyzed isomerization of alkyne $\mathbf{8 2}$ to $\mathbf{8 3}$, which in turn will undergo a cycloadditon to give $\mathbf{8 4}$, followed by a 1,5 -proton migration to give $\mathbf{8 5}$. While there are many approaches to this natural product, ${ }^{51}$ none of these approaches could compare to the Wang route in terms of overall efficiency and flexibility.

As a prelude to the eventual glycosylation of synthetic hydroxy-substituted camptothecins from the above route, we decided to work with the natural product instead. We could do this because camptothecin already has a hydroxyl group and is commercially available, 
albeit expensive. This idea was drawn from the fact that nature already produced a glycosylated camptothecin (see gluco-camptothecin, Figure 12), which had also shown improved biological activity, presumably as a pro-drug. That is to say, the glucose must be hydrolyzed before the camptothecin can bind to DNA.

Scheme 32: Attempted glycosylation of the tertiary hydroxyl of Camptothecin
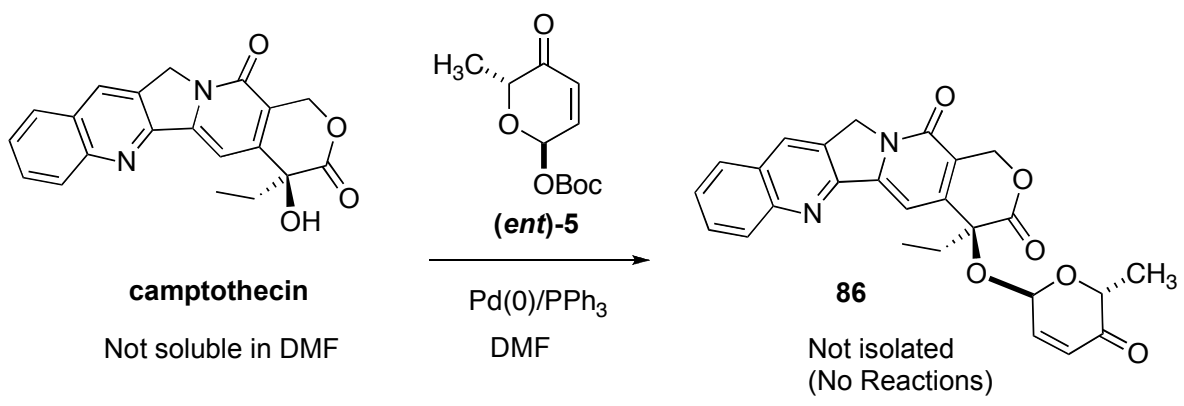

Encouraged by the fact that the tertiary alcohol of camptothecin can be glycosylated in nature, we began our efforts with the attempt to use our palladium-catalyzed glycosylation reaction on the tertiary alcohol of camptothecin (Scheme 32). Unfortunately, these reactions failed. We believed this was primarily due to the poor solubility of camptothecin in most organic solvents. The only non-protic solvent we were able to get camptothecin to dissolve into was refluxing acetic anhydride, which could not be used in the glycosylation reaction.

We attributed this lack of reactivity to solubility, instead of reactivity, because the related camptothecin SN-38 (Scheme 33) has a much more reactive phenol that also did not react, presumably due to the poor solubility in DMF. This poor solubility also inhibited our efforts to 
functionalize the pyridine ring in camptothecin by an $N$-oxide to pyridone rearrangement reagent (e.g., $\mathbf{8 8}$ to $\mathbf{8 9}, \mathrm{X}=\mathrm{OH}$, Scheme 34 ).

Scheme 33: Attempted glycosylation of the phenolic OH of $\mathrm{SN}-38$

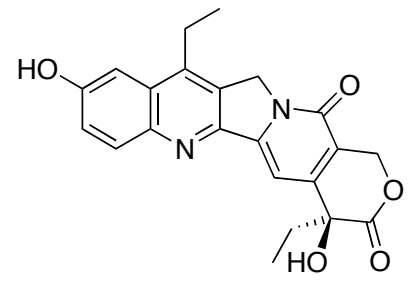

SN-38

Not soluble in DMF

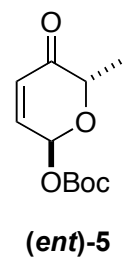

(ent)-5

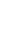

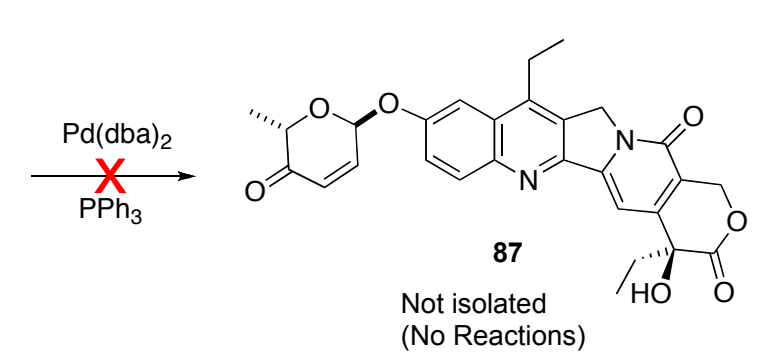

Based on these results, we decided to install sugars via a Sonogashira reaction with glycosylated propargyl alcohols (Scheme 34 ). We chose to prepare a camptothecin with a $C-11$ leaving group for palladium cross coupling partner (e.g., 89, $\mathrm{X}=\mathrm{Cl}, \mathrm{Br}$, I, OTf). This effort began with the attempted synthesis of known $C$-11-substituted camptothecins with either a hydroxyl or triflate group. Unfortunately, this effort failed with our inability to purify the highly insoluble and unstable camptothecin $N$-oxide $\mathbf{8 8}$.

Improved solubility of the camptothecins came with the acylation of the tertiary alcohol, which after acylation could be oxidized and rearranged to the desired $C-11$ chloro-pyridine..$^{52}$ Acylation of the $C$-4 tertiary hydroxyl group of camptothecin was accomplished by exposing camptothecin with 1 equiv of $\mathrm{LiBr}$ in refluxing acetic anhydride to provide good yield of camptothecin acetate 90 (92\% yield). ${ }^{53}$ This more soluble substrate could be oxidized with excess mCPBA in refluxing EtOAc/ $\mathrm{CH}_{2} \mathrm{Cl}_{2}$ to give a good yield of the $\mathrm{N}$-oxide 91 (quantitative yield). The $\mathrm{N}$-oxide 91 was unstable to silica gel chromatography, however, reasonably pure 
material could be prepared by aqueous base extraction of the excess acid and re-crystallization. The $N$-oxide 91 was converted to the $C$ - 11 chloride 92 by exposure of a $\mathrm{DMF} / \mathrm{CH}_{2} \mathrm{Cl}_{2}$ solution to oxalyl chloride in $76 \%$ yield..$^{54}$

Scheme 34: Attempted synthesis of 11-substituted Camptothecin for Sonogashira coupling

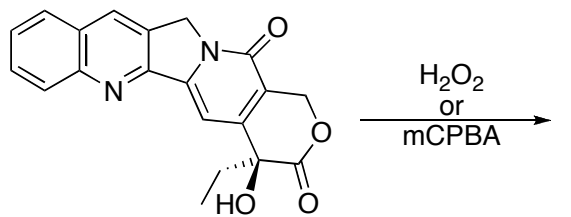

Camptothecin $\mid \begin{aligned} & \mathrm{Ac}_{2} \mathrm{O} / \mathrm{LiBr} \\ & 92 \%\end{aligned}$<smiles>CC[C@]1(O)C(=O)OCc2c1cc1n(c2=O)Cc2cc3ccccc3[n+]([O-])c2-1</smiles>

88

difficult to purify

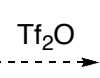<smiles>[X]c1c2c(nc3ccccc13)-c1cc3c(c(=O)n1C2)COC(=O)[C@]3(O)CC</smiles>

11-substituted Camptothecin

89<smiles>COC1(OC(C)=O)C(=O)OCc2c1cc1n(c2=O)Cc2cc3ccccc3nc2-1</smiles>

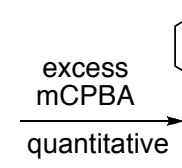<smiles></smiles><smiles>COC(=O)CCCCCO</smiles><smiles>CCC1(OC(C)=O)C(=O)OCc2c1cc1n(c2=O)Cc2c-1nc1ccccc1c2Cl</smiles>

With chloride 92 in hand, we next investigated its use in the Sonogashira coupling reaction with various propargyl alcohols (Scheme 35). This effort built on the work of Lu and co-workers, ${ }^{55}$ who demonstrated the use of 7-chloro-camptothecin 92 in the Buchwald copperfree Sonogashira coupling reaction. ${ }^{56}$ Exposing 7-chloro camptothecin 92 with THP-protected propargyl alcohol to catalytic $\mathrm{Pd}(\mathrm{OAc})_{2} / \mathrm{BINAP}$ in refluxing toluene gave good yields of alkyne 94 (75\% yield).

\footnotetext{
"While the compounds in Scheme 34 are known compounds in the patent literature, their experimental and spectral details were not included, see, ref. 52.
} 
While this route worked for very simple substrates like THP-protected propargyl alcohol 93, it failed to give adequate amount of pure products for our desired glycosylated propargylic alcohol coupling partners. When we exposed our glycosylated propargyl alcohols 95-97 to the same Sonogashira coupling conditions, only trace amount of the desired product was detected for the coupling reaction with $\mathbf{9 7}$. Evidence of the slightly successful coupling reaction between $\mathbf{9 2}$ and 97 was seen when the crude reactions products were compared to authentic material (99, Scheme 36).

Scheme 35: Attempted synthesis of glycosylated Camptothecin via Sonogashira coupling<smiles>CCC1(OC(C)=O)C(=O)OCc2c1cc1n(c2=O)Cc2c-1nc1ccccc1c2Cl</smiles>

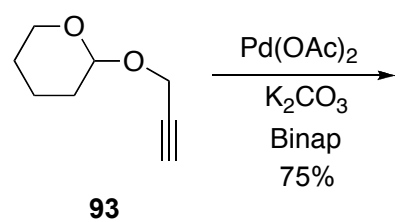<smiles>CCC1(OC(C)=O)C(=O)OCc2c1cc1n(c2=O)Cc2c-1nc1ccccc1c2C#CCOC1CCCCO1</smiles><smiles>C#CCOC1OCCC(O)C1O</smiles>

95<smiles>C=CC1C=CC(O)CCO1</smiles>

96<smiles>[CH]C=CCOC1C=CC(=O)C(C)O1</smiles>

97

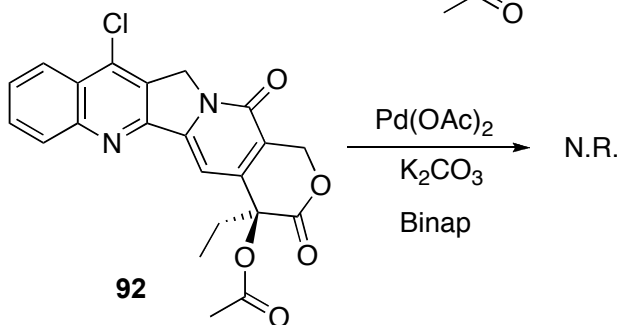

With the lack of success with the more convergent Sonogashira coupling strategy, we turned to an alternative protocol for the synthesis of glycosylated camptothecin, like 99. This began with the acid-catalyzed deprotection of the THP-group to give propargyl alcohol $\mathbf{9 8}(95 \%$ yield). Using our palladium catalyzed glycosylation of propagyl alcohol 98 with the $\beta$-pyranone 
6, we were able to convert 98 in to pyranone 99. Unfortunately, the less stable $\beta$-pyranone isomerized upon silica gel chromatography, which caused difficulty in separating the mixture of diastereomers at the anomeric position $(65 \%)$.

Scheme 36: Attempted synthesis of glycosylated Camptothecin via Sonogashira coupling
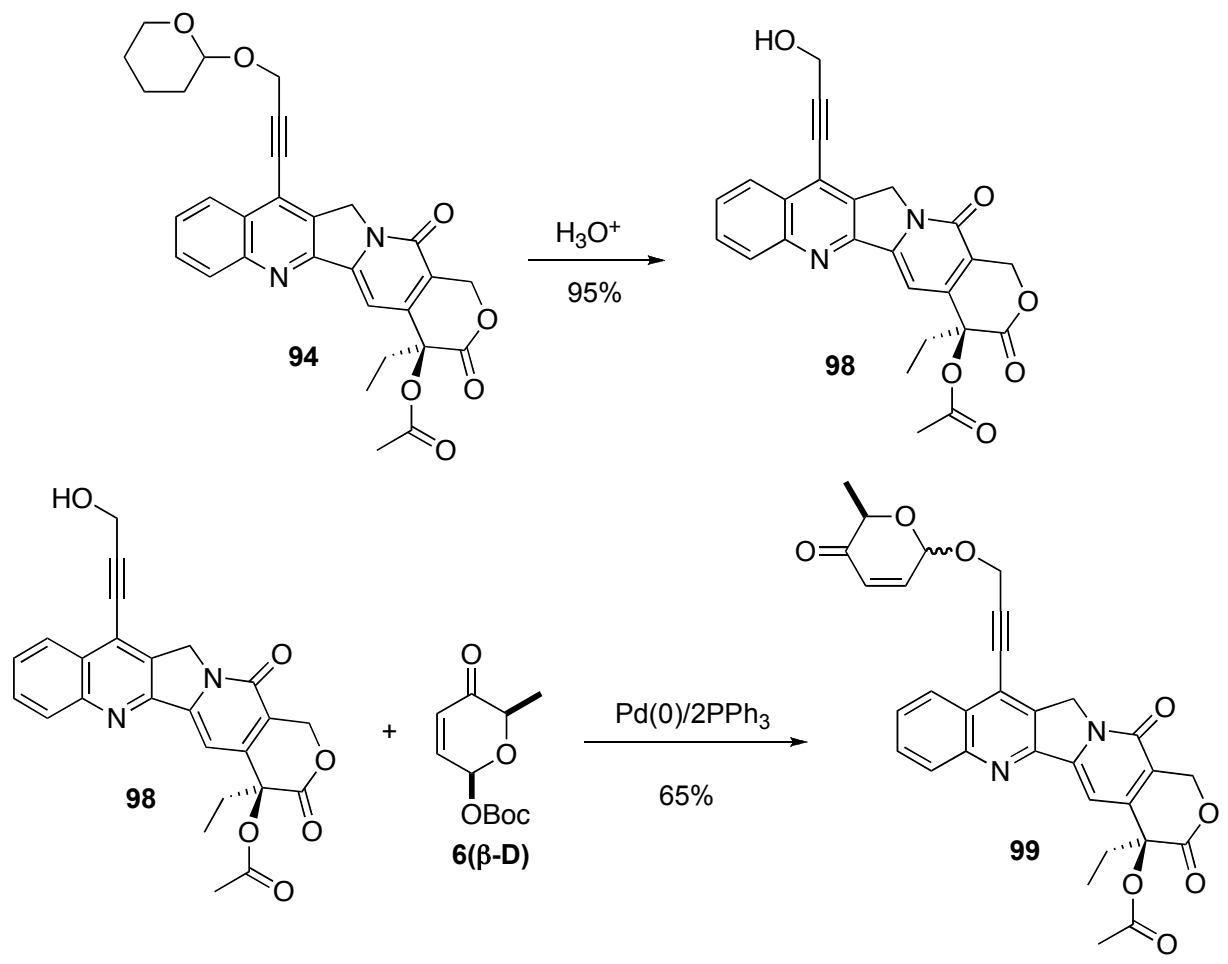

Finally, a successful effort to prepare a glycosylated camptothecin came when we acylated the tertiary alcohol of SN-38 (Scheme 37). This acetate group imparted improved solubility to the camptothecin substrate. Unfortunately, due to the greater reactivity of phenol groups, a two-step acylation/deacylation sequence was needed to acylate the less reactive tertiary alcohol (Scheme 37). Thus both the phenol and tertiary alcohol were acylated with acetic anhydride to give diacetate 101 (65\% yield). The more reactive phenol was then removed with 
$\mathrm{MeOH} / \mathrm{Et}_{3} \mathrm{~N}$ to give the desired mono-acetate 102 (50\% yield). Alternatively, the more reactive phenol could be protected with a TBS group to give $\mathbf{1 0 3}$ in excellent yield $(83 \%)$. Then the tertiary alcohol was acylated to form 104 (92\%). Finally, a TBS deprotection with HF/Py gave the desired phenol $102(92 \%)$. On small scale this later route was the higher yielding, but upon scale up, problem occurred with the formation of diacetate under the acylation conditions. ${ }^{54}$

Scheme 37: Synthesis of a more soluble analogue of $S N-38$

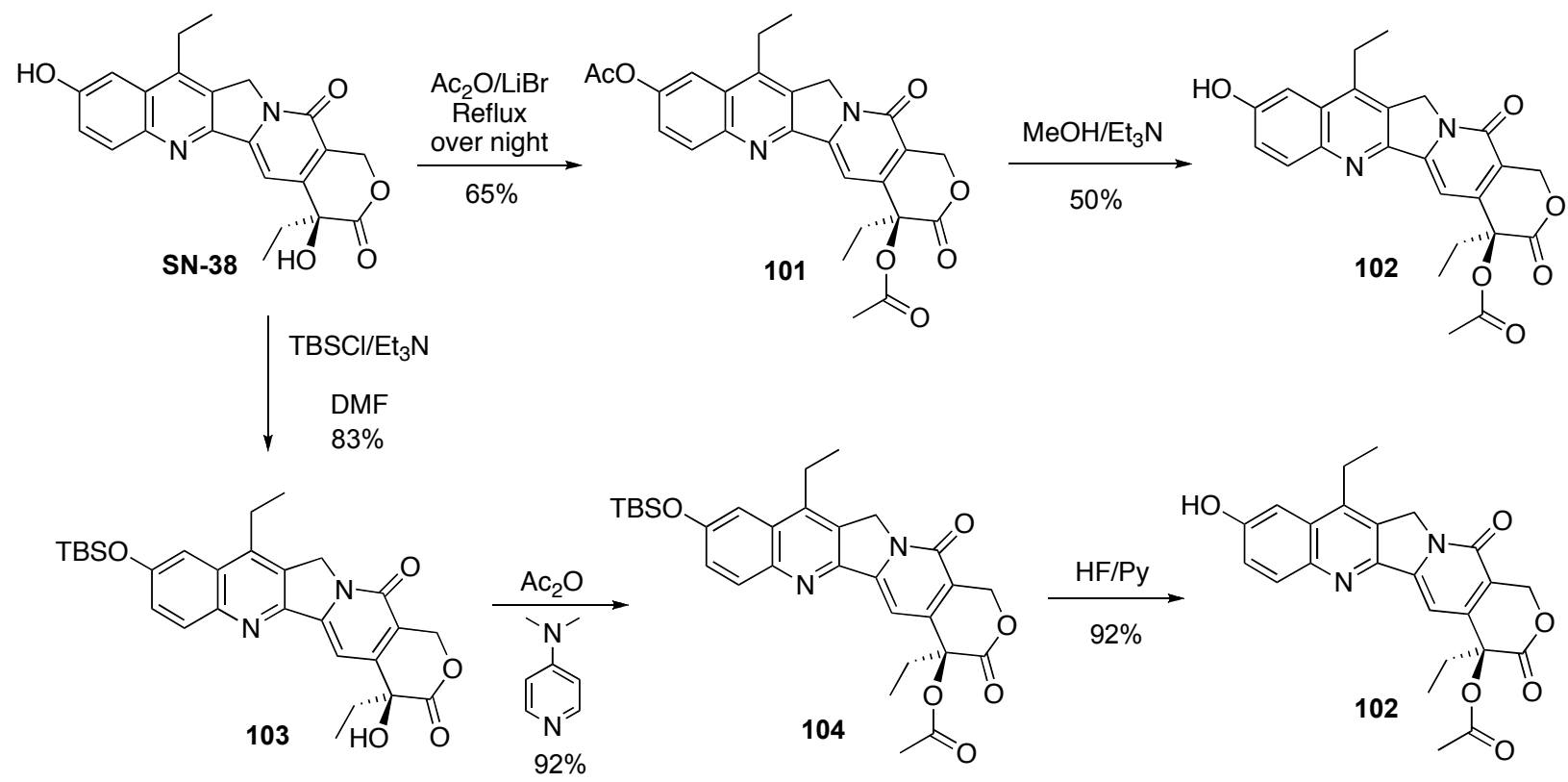

Finally, with the acylated SN-38 102 in hand, we were able to perform the desired Pdcatalyzed glycosylation. This was performed with both the pyranone $\mathbf{5}$ and allylic alcohol $\mathbf{1 0 6}$ as $\pi$-allyl-precursors. Unfortunately, the pyranone glycosylation product 105 was not very stable, and had to be reduced to allylic alcohol 107 without further purification $(\sim 50 \%)$. Alternatively, the allylic alcohol product 107 could be prepared in better overall yield when 102 was 
glycosylated with $106(83 \%)$. While more stable than 105, the allylic alcohol 107 was still unstable to acidic conditions. Allylic alcohol 107 smoothly underwent dihydroxylation when it was exposed to the typical Upjohn conditions to provide rhamno-SN-38 $108(85 \%)$. While the glycosylated camptothecin 108 was significantly more stable than 105 and 107, it slowly underwent methanolysis to form the free aglycon 102 and methyl rhamno-pyranoside upon standing in methanol. Because of the expense of the $\mathrm{SN}-38$ and overall instability of glycosylated product $\mathbf{1 0 8}$, we decided not to pursue the synthesis of further glycosylated camptothecin analogues.

Scheme 38: Successful synthesis of a glycosylated Camptothecin $S N-38$
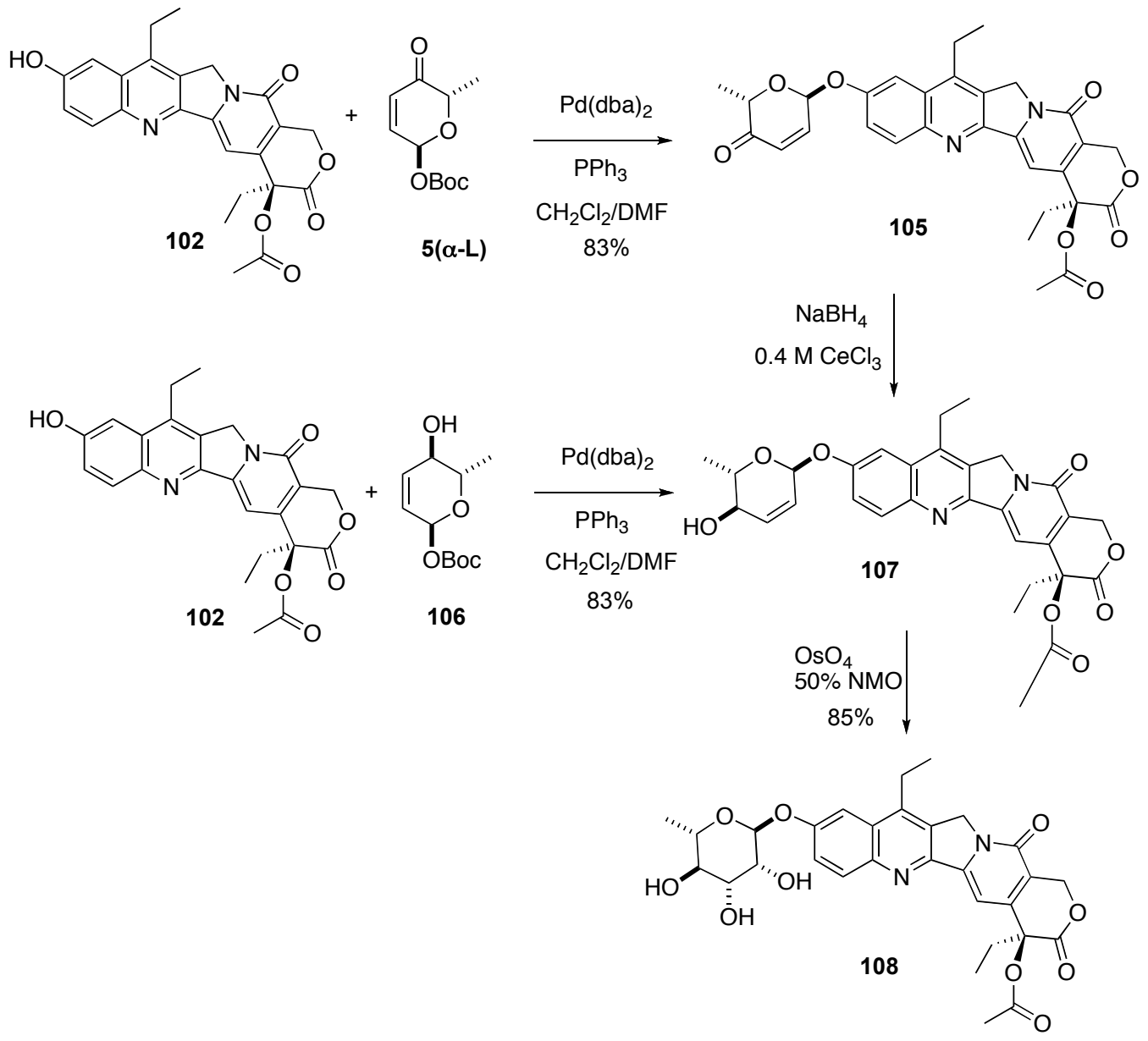
Scheme 39: Reason for potential instability of glycosylated $S N-38$<smiles>CCc1c2c(nc3ccc(OC4C=CC(=O)[C@@H](C)O4)cc13)-c1cc3c(c(=O)n1C2)COC(=O)[C@]3(CC)OC(C)=O</smiles><smiles>CCc1c2c(nc3ccc(O)cc13)-c1cc3c(c(=O)n1C2)C[OH+]C(=O)C3(OC(C)=O)OC(C)=O</smiles><smiles>CCc1c2c(nc3ccc(OC4C=C[C@H](O)[C@H](C)O4)cc13)-c1cc3c(c(=O)n1C2)COC(=O)C3(OC(C)=O)OC(C)=O</smiles><smiles></smiles><smiles>CCc1c2c(nc3ccc(OC4O[C@H](C)[C@@H](O)[C@H](O)[C@H]4O)cc13)-c1cc3c(c(=O)n1C2)COC(=O)C3(OC(C)=O)OC(C)=O</smiles><smiles></smiles>

While it was not thought to be a major problem at the outset, the base instability of pyranone 105 and the acid instability of $\mathbf{1 0 7}$ and $\mathbf{1 0 8}$ were not without precedent (Scheme 39). For instance, it is well known that pyranones, like 105, with good leaving groups at the $C-1$ position, decomposes in the presence of a base to give 1,3-dipole intermediates like 110. The basic nature of the pyridine ring in the camptothecin aglycon can lead to its protonation, making it a much better leaving group, which makes both 107 and 108 more prone to acid-catalyzed 
hydrolysis (107 to 112 and 108 to 113 ). Due to the presence of the double bond, it is not surprising that $\mathbf{1 0 7}$ is more sensitive to acid hydrolysis than $\mathbf{1 0 8}$.

In conclusion, we have shown that glycosylated camptothecin can be made, but their syntheses can be complicated by issues associated with poor solubility of the ring system. This solubility problem was a bigger issue in synthesis of aza-ellipticines, such that it prevented the synthesis of the desired hydroxy-aza-ellipticine substrates for our proposed glycosylation studies.

Scheme 40: Future goals
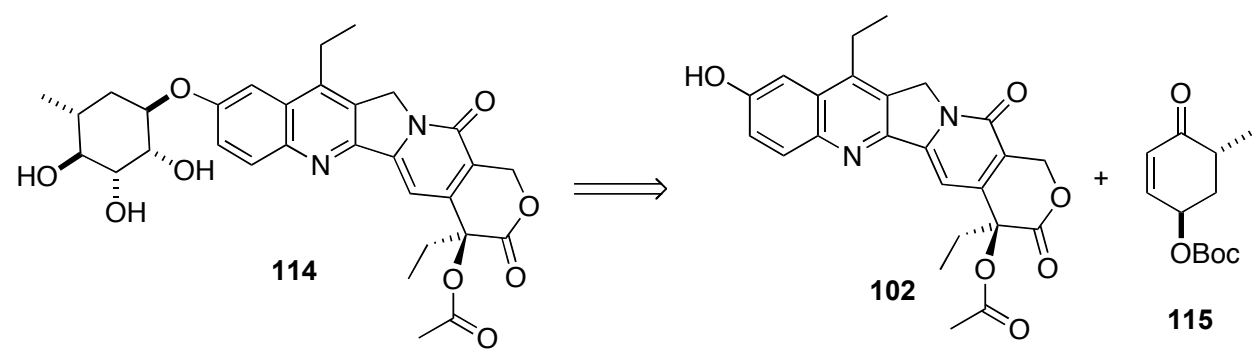

While the acid sensitivity of glycosylated SN-38 (108) will limit its use as a drug, we believe that future efforts in this regard could include the synthesis of cylictol analogues like $\mathbf{1 1 4}$. 


\section{Chapter IV. Experimental Section}

\section{A. General methods and materials:}

${ }^{1} \mathrm{H}$ and ${ }^{13} \mathrm{C}$ spectra were recorded on $270 \mathrm{MHz}$ and $600 \mathrm{MHz}$ spectrometers. Chemical shifts were reported relative to benzene- $\mathrm{d}_{6}(\delta 7.16 \mathrm{ppm}), \mathrm{CDCl}_{3}(\delta 7.26 \mathrm{ppm}), \mathrm{CD}_{3} \mathrm{OD}(\delta 3.31 \mathrm{ppm})$, acetone- $\mathrm{d}_{6}(\delta 2.05 \mathrm{ppm}), \mathrm{D}_{2} \mathrm{O}(\delta 4.80 \mathrm{ppm})$ for ${ }^{1} \mathrm{H}$, and benzene- $\mathrm{d}_{6}(\delta 127.68 \mathrm{ppm}), \mathrm{CDCl}_{3}(\delta$ $77.0 \mathrm{ppm}), \mathrm{CD}_{3} \mathrm{OD}(\delta 49.15 \mathrm{ppm})$, and acetone- $\mathrm{d}_{6}(\delta 29.92 \mathrm{ppm})$ for ${ }^{13} \mathrm{C}$. Optical rotations were measured with a digital polarimeter in the solvent specified. Infrared (IR) spectra were obtained on a FT-IR spectrometer. Flash column chromatography was performed on 60-200 mesh silica gel. Analytical thin-layer chromatography was performed with precoated glass-backed plates and visualized by quenching of fluorescence and by charring after treatment with p-anisaldehyde or phosphomolybdic acid or potassium permanganate stain. $R_{f}$ values were obtained by elution in the stated solvent ratios $(\mathrm{v} / \mathrm{v})$. Ether, THF, methylene chloride, toluene and triethylamine were dried by passing through activated alumina ( 8 x 14 mesh) column with argon gas pressure. Commercial reagents were used without purification unless otherwise noted. Air and/or moisture-sensitive reactions were carried out under an atmosphere of argon/nitrogen using oven/flamed-dried glassware and standard syringe/septum techniques. 


\section{B: Experimental Procedures for Chapter I:}

\section{(R)-1-(furan-2-yl) ethanol $(7(R))^{\S}$}

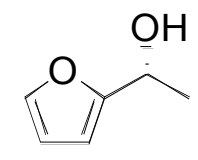

To a $250 \mathrm{~mL}$ flask was added furan ketone 8 (22 $\mathrm{g}, 0.2 \mathrm{~mol}), \mathrm{CH}_{2} \mathrm{Cl}_{2}(100 \mathrm{~mL})$, formic acid/triethylamine $(1: 1,108 \mathrm{~mL})$ and Noyori asymmetric transfer hydrogenation catalyst $(R)$ $\mathrm{Ru}\left(\eta^{6}\right.$-mesitylene)-(R,R)-TsDPEN (585 mg, $\left.0.5 \mathrm{~mol} \%\right)$. The resulting solution was stirred at room temperature for $24 \mathrm{~h}$. The reaction mixture was diluted with water $(150 \mathrm{~mL})$ and extracted with $\mathrm{Et}_{2} \mathrm{O}(3 \times 150 \mathrm{~mL})$. The combined organic layers were washed with satd. aq. $\mathrm{NaHCO}_{3}$, dried over $\mathrm{Na}_{2} \mathrm{SO}_{4}$, and concentrated under reduced pressure. The crude product was purified by silica gel flash chromatography eluting with $20 \% \mathrm{Et}_{2} \mathrm{O} /$ hexanes to give furan alcohol $7(\boldsymbol{R})(21.5$ $\mathrm{g}, 0.19 \mathrm{mmol}, 96 \%)$ as a colorless oil; $R_{f}\left(30 \% \mathrm{Et}_{2} \mathrm{O} / \mathrm{hexanes}\right)=0.24 ;[\alpha]_{\mathrm{D}}^{21}+20.8(c 1.20$, $\mathrm{CHCl}_{3}$ ); IR (thin film, $\mathrm{cm}^{-1}$ ) 3361, 2979, 2934, 1669, 1504, 1465, 1371, 1230, 1148, 1008, 878, 735; ${ }^{1} \mathrm{H}$ NMR $\left(270 \mathrm{MHz} \mathrm{CDCl}_{3}\right) \delta 7.37(\mathrm{~d}, J=1.8 \mathrm{~Hz}, 1 \mathrm{H}), 6.32(\mathrm{dd}, J=3.2,1.8 \mathrm{~Hz}, 1 \mathrm{H}), 6.22$ (ddd, $J=3.2 \mathrm{~Hz}, 1 \mathrm{H}), 4.87(\mathrm{q}, J=6.5 \mathrm{~Hz}, 1 \mathrm{H}), 2.25(\mathrm{bs}, 1 \mathrm{H}), 1.53(\mathrm{~d}, J=8.0 \mathrm{~Hz}, 3 \mathrm{H}) ;{ }^{13} \mathrm{C} \mathrm{NMR}$ $\left(67.5 \mathrm{MHz}, \mathrm{CDCl}_{3}\right) \delta 158.0,142.3,110.5,105.5,64.0,21.7$.

\footnotetext{
${ }^{\S}$ Spectral data matches that for previously reported material, see: Shan, M.; O’Doherty, G. A. Org. Lett. 2006, 8, 5149-5152.
} 


\section{(S)-1-(2-Furyl)-ethanol (7(S)): ${ }^{\S}$}

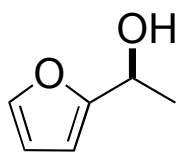

To a $250 \mathrm{~mL}$ flask was added furan ketone $8(8 \mathrm{~g}, 72.7 \mathrm{mmol}), \mathrm{CH}_{2} \mathrm{Cl}_{2}(37 \mathrm{~mL})$, formic acid/triethylamine $(1: 1,100 \mathrm{~mL})$ and Noyori asymmetric transfer hydrogenation catalyst $(R)$ $\mathrm{Ru}\left(\eta^{6}\right.$-mesitylene)-(S,S)-TsDPEN (222 $\left.\mathrm{mg}, 0.5 \mathrm{~mol} \%\right)$. The resulting solution was stirred at room temperature for $24 \mathrm{~h}$. The reaction mixture was diluted with water $(100 \mathrm{~mL})$ and extracted with $\mathrm{Et}_{2} \mathrm{O}(3 \times 100 \mathrm{~mL})$. The combined organic layers were washed with satd. aq. $\mathrm{NaHCO}_{3}$, dried over $\mathrm{Na}_{2} \mathrm{SO}_{4}$, and concentrated under reduced pressure. The crude product was purified by silica gel flash chromatography eluting with $20 \% \mathrm{Et}_{2} \mathrm{O} /$ hexanes to give furan alcohol $7(\boldsymbol{S})(7.82$ $\mathrm{g}, 69.8 \mathrm{mmol}, 96 \%)$ as a colorless oil; $R_{f}\left(30 \% \mathrm{Et}_{2} \mathrm{O} /\right.$ hexanes $)=0.24 ;[\alpha]_{\mathrm{D}}^{21}-20.1\left(c 1.0, \mathrm{CHCl}_{3}\right)$; IR (thin film, $\mathrm{cm}^{-1}$ ) 3360, 2980, 2935, 1668, 1505, 1467, 1370, 1229, 1149, 1007, 877, 734; ${ }^{1} \mathrm{H}$ $\operatorname{NMR}\left(270 \mathrm{MHz} \mathrm{CDCl}_{3}\right) \delta 7.37(\mathrm{dd}, J=1.6,0.8 \mathrm{~Hz}, 1 \mathrm{H}), 6.32(\mathrm{dd}, J=3.2,1.8 \mathrm{~Hz}, 1 \mathrm{H}), 6.23$ (ddd, $J=3.2,0.8,0.8 \mathrm{~Hz}, 1 \mathrm{H}), 4.78(\mathrm{dq}, J=3.4,6.1 \mathrm{~Hz}, 1 \mathrm{H}), 2.07$ (bs, 1H), 1.54 (d, $J=6.5 \mathrm{~Hz}$, $3 \mathrm{H}) ;{ }^{13} \mathrm{C} \mathrm{NMR}\left(67.5 \mathrm{MHz}, \mathrm{CDCl}_{3}\right) \delta 157.7,141.6,109.9,104.9,63.3,21.1$. 
(2R)-6-Hydroxy-2- methyl-2H-Pyran-3 (6H)-one (34): ${ }^{\S}$

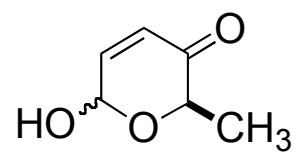

Furan alcohol $7(\boldsymbol{R})(9.0 \mathrm{~g}, 79.5 \mathrm{mmol}), 100 \mathrm{~mL}$ of $\mathrm{THF}$, and $25 \mathrm{~mL}$ of $\mathrm{H}_{2} \mathrm{O}$ were added to a round bottom flask and cooled to $0{ }^{\circ} \mathrm{C}$. Solid $\mathrm{NaHCO}_{3}(13.4 \mathrm{~g}, 159 \mathrm{mmol}), \mathrm{NaOAc} \cdot 3 \mathrm{H}_{2} \mathrm{O}(10.8 \mathrm{~g}$, $79.5 \mathrm{mmol})$, and NBS (14.9 $\mathrm{g}, 83.48 \mathrm{mmol})$ were added to the solution and the mixture was stirred for $1 \mathrm{~h}$ at $0{ }^{\circ} \mathrm{C}$. The reaction was quenched with satd. aq. $\mathrm{NaHCO}_{3}(200 \mathrm{~mL})$, extracted (3 x $200 \mathrm{~mL}$ ) with $\mathrm{Et}_{2} \mathrm{O}$, dried $\left(\mathrm{Na}_{2} \mathrm{SO}_{4}\right)$, concentrated under reduced pressure and purified by silica gel chromatography eluting with 35\% EtOAc/hexanes to give pyranone 34 (9.67 g, $75.5 \mathrm{mmol}$, 95\%, $\alpha: \beta=2.6: 1): R_{\mathrm{f}}(60 \%$ EtOAc/hexanes $)=0.29 ;$ IR $\left(\right.$ thin film, $\left.\mathrm{cm}^{-1}\right) 3381,2988,2942,1692$, 1447, 1373, 1232, 1021, 937; ${ }^{1} \mathrm{H}$ NMR (600 MHz, $\left.\mathrm{CDCl}_{3}\right)$ major isomer $(\alpha): \delta 6.86(\mathrm{dd}, J=10.2$, $3.0 \mathrm{~Hz}, 1 \mathrm{H}), 6.04(\mathrm{~d}, J=10.2 \mathrm{~Hz}, 1 \mathrm{H}), 5.57(\mathrm{dd}, J=4.2,3.6 \mathrm{~Hz}, 1 \mathrm{H}), 4.66(\mathrm{q}, J=6.6 \mathrm{~Hz}, 1 \mathrm{H})$, $4.36(\mathrm{~d}, J=5.4 \mathrm{~Hz}, 1 \mathrm{H}), 1.32(\mathrm{~d}, J=6.6 \mathrm{~Hz}, 3 \mathrm{H})$; minor isomer $(\beta): \delta 6.91(\mathrm{dd}, J=10.2,1.8 \mathrm{~Hz}$, 1H), $6.09(\mathrm{dd}, J=10.2,1.8 \mathrm{~Hz}, 1 \mathrm{H}), 5.62(\mathrm{dd}, J=7.2,1.2 \mathrm{~Hz}, 1 \mathrm{H}), 4.71(\mathrm{~d}, J=7.2 \mathrm{~Hz}, 1 \mathrm{H}), 4.18$ $(\mathrm{dq}, J=1.2,6.6 \mathrm{~Hz}, 1 \mathrm{H}), 1.39(\mathrm{~d}, J=6.6 \mathrm{~Hz}, 3 \mathrm{H}) ;{ }^{13} \mathrm{C} \mathrm{NMR}\left(150 \mathrm{MHz}, \mathrm{CDCl}_{3}\right)$ major isomer $(\alpha): \delta 197.4,144.9,126.9,87.4,70.3,15.2$. Minor isomer $(\beta): \delta 196.8,148.5,128.2,87.2,90.8$, $75.1,16.1$ 
Tert-butyl (2S,6R)-5,6-dihydro-6-methyl-5-oxo-2H-pyran-2-yl carbonate $((e n t)-5(\alpha-\mathrm{D}))$ and Tert-butyl (2R,6R)-5,6-dihydro-6-methyl-5-oxo-2H-pyran-2-yl carbonate $(6(\beta-\mathrm{D}))^{* *}$

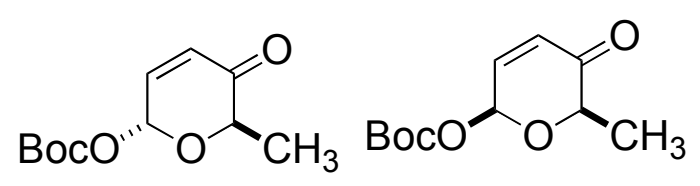

To a benzene solution (300 mL) of (5R)-1-Hydroxy-5-tert-butyl dimethylsilanyloxymethyl-5Hpyran 4-(1H)-one A $(18.5 \mathrm{~g}, 0.144 \mathrm{~mol})$ and $(\mathrm{Boc})_{2} \mathrm{O}(47.3 \mathrm{~g}, 0.22 \mathrm{~mol})$ was added sodium acetate $(13.2 \mathrm{~g}, 0.16 \mathrm{~mol})$. After stirring at $80{ }^{\circ} \mathrm{C}$ for $2 \mathrm{~h}$, the mixture was cooled down to room temperature. The reaction was quenched by adding of $300 \mathrm{~mL}$ of satd. aq. $\mathrm{NaHCO}_{3}$ solution, extracted $(3 \times 300 \mathrm{~mL})$ with $\mathrm{Et}_{2} \mathrm{O}$, dried $\left(\mathrm{Na}_{2} \mathrm{SO}_{4}\right)$, and concentrated under reduced pressure. The crude product was purified by silica gel flash chromatography eluting with 6 and $8 \%$ EtOAc/hexanes to give two diastereomers of tert-butyl 5,6-dihydro-6-methyl-5-oxo-2H-pyran-2yl carbonate $(29.0 \mathrm{~g}, 0.127 \mathrm{~mol}, 88 \%)$ of $(\boldsymbol{e n t})-\mathbf{5}(\boldsymbol{\alpha}-\mathrm{D})$ and $\mathbf{6}(\boldsymbol{\beta}-\mathrm{D})(\mathrm{d} . \mathrm{r} .=1: 1.3)$.

$($ ent $)-5(\alpha-\mathrm{D}): R f\left(20 \% \mathrm{Et}_{2} \mathrm{O} /\right.$ hexanes $)=0.43 ;[\alpha]_{\mathrm{D}}^{21}=-97.1\left(\mathrm{c} 1.0, \mathrm{CH}_{2} \mathrm{Cl}_{2}\right) ; \mathrm{IR}\left(\right.$ thin film, $\left.\mathrm{cm}^{-1}\right)$ 2986, 1752, 1703, 1633, 1278, 1258, 1159, 1090, 1058, 1029, $944 ;{ }^{1} \mathrm{H}$ NMR (600 MHz, $\left.\mathrm{CDCl}_{3}\right)$ $\delta 6.795(\mathrm{dd}, J=10.2,4.2 \mathrm{~Hz}, 1 \mathrm{H}), 6.24(\mathrm{~d}, J=4.2 \mathrm{~Hz}, 1 \mathrm{H}), 6.10(\mathrm{~d}, J=10.2 \mathrm{~Hz}, 1 \mathrm{H}), 4.55(\mathrm{q}, J$ $=6.6 \mathrm{~Hz}, 1 \mathrm{H}), 1.40(\mathrm{~s}, 9 \mathrm{H}), 1.30(\mathrm{~d}, J=6.7 \mathrm{~Hz}, 3 \mathrm{H}) ;{ }^{13} \mathrm{C} \mathrm{NMR}(150 \mathrm{MHz}, \mathrm{CDCl} 3) \delta 195.4$, 151.7, 140.9, 128.1, 89.0, 83.2, 71.9, 27.4(3C), 15.0; HRCIMS Calcd for $\left[\mathrm{C}_{11} \mathrm{H}_{16} 0_{5} \mathrm{Na}\right]^{+}$: 251.0890, Found 251.0884.

\footnotetext{
${ }^{* *}$ Spectral data matches that for previously reported material, see: Zhou and G. A. O’Doherty, J. Org. Chem. 2007, $72,2485-2493$.
} 
6( $\beta$-D): $R f(20 \%$ EtOAc/hexanes $)=0.50 ; \mathrm{mp}: 43-43.5^{\circ} \mathrm{C} ;[\alpha]_{\mathrm{D}}^{21}=+42.3\left(\mathrm{c} 1.3, \mathrm{CHCl}_{3}\right)$; IR (thin film, $\left.\mathrm{cm}^{-1}\right) 2986,1752,1703,1633,1278,1258,1159,1090,1058,1029,944 ;{ }^{1} \mathrm{H}$ NMR (600 $\left.\mathrm{MHz}, \mathrm{CDCl}_{3}\right) \delta 6.82(\mathrm{dd}, J=10.2,2.4 \mathrm{~Hz}, 1 \mathrm{H}), 6.28(\mathrm{dd}, J=2.4,1.2 \mathrm{~Hz}, 1 \mathrm{H}), 6.11(\mathrm{dd}, J=$ 10.2, 1.2 Hz, 1H), $4.27(\mathrm{q}, J=6.6 \mathrm{~Hz}, 1 \mathrm{H}), 1.42(\mathrm{~s}, 9 \mathrm{H}), 1.39(\mathrm{~d}, J=6.9 \mathrm{~Hz}, 3 \mathrm{H}) ;{ }^{13} \mathrm{C}$ NMR $(150 \mathrm{MHz}, \mathrm{CDCl} 3) \delta 195.6,151.6,142.7,128.0,89.7,83.3,75.5,27.4(3 \mathrm{C}), 18.3$; HRCIMS Calcd for $\left[\mathrm{C}_{11} \mathrm{H}_{16} \mathrm{O}_{5} \mathrm{Na}\right]+:$ 251.0890, Found 251.0883. 
$(2 S, 6 S)-t$-butyl -5,6-dihydro-6-methyl-5-oxo-2H-pyran-2-yl carbonate $(5(\alpha-\mathrm{L}))^{* *}$

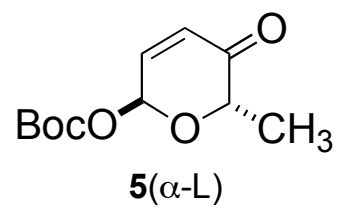

Alcohol (ent)-34 (5.5 g, $42.9 \mathrm{mmol})$ was dissolved in $\mathrm{CH}_{2} \mathrm{Cl}_{2}(42 \mathrm{~mL})$ and the solution was cooled to $-78^{\circ} \mathrm{C}$. $\mathrm{A} \mathrm{CH}_{2} \mathrm{Cl}_{2}(2 \mathrm{~mL})$ solution of $(\mathrm{Boc})_{2} \mathrm{O}(13.46 \mathrm{~g}, 51.6 \mathrm{mmol})$ and a catalytic amount of DMAP $(524.2 \mathrm{mg}, 4.76 \mu \mathrm{mol})$ was added to the reaction mixture. The reaction was stirred for $1 \mathrm{~h}$ at $-78{ }^{\circ} \mathrm{C}$, and quenched with $100 \mathrm{~mL}$ of satd. aq. $\mathrm{NaHCO}_{3}$, extracted with $\mathrm{Et}_{2} \mathrm{O}(3$ x $100 \mathrm{~mL})$, dried $\left(\mathrm{Na}_{2} \mathrm{SO}_{4}\right)$, and concentrated under reduced pressure. The crude product was purified using silica gel flash chromatography eluting with 6\% EtOAc/hexanes to give $8.02 \mathrm{~g}$ (35.2 mmol, 82\%) of two diastereomers of Boc-protected pyranone $\mathbf{5}(\boldsymbol{\alpha}-\mathbf{L})$ and $(e n t)-\mathbf{6}(\boldsymbol{\beta}-\mathbf{L})$ in a ratio of 3:1. $5(\boldsymbol{\alpha}-\mathbf{L}): \mathrm{R}_{f}\left(20 \% \mathrm{Et}_{2} \mathrm{O} /\right.$ hexanes $)=0.58 ;[\alpha]_{\mathrm{D}}^{21}=+98\left(\mathrm{c}=1.0, \mathrm{CH}_{2} \mathrm{Cl}_{2}\right)$; IR (thin film, cm-1) 2984, 2942, 1752, 1703, 1371, 1273, 1254, 1153, 938, 838; ${ }^{1} \mathrm{H}$ NMR (600 MHz, $\left.\mathrm{CDCl}_{3}\right) \delta 6.78(\mathrm{dd}, \mathrm{J}=10.2,3.6 \mathrm{~Hz}, 1 \mathrm{H}), 6.22(\mathrm{~d}, \mathrm{~J}=3.6 \mathrm{~Hz}, 1 \mathrm{H}), 6.09(\mathrm{~d}, \mathrm{~J}=10.2 \mathrm{~Hz}, 1 \mathrm{H}), 4.53$ $(\mathrm{q}, \mathrm{J}=6.6 \mathrm{~Hz}, 1 \mathrm{H}), 1.40(\mathrm{~s}, 9 \mathrm{H}), 1.28(\mathrm{~d}, \mathrm{~J}=6.6 \mathrm{~Hz}, 3 \mathrm{H}) ;{ }^{13} \mathrm{C} \mathrm{NMR}\left(150 \mathrm{MHz}, \mathrm{CDCl}_{3}\right) \delta 195.5$, 151.7, 140.9, 128.2, 89.1, 83.3, 72.0, 27.5, 15.1; ClHRMS Calculated for $\left[\mathrm{C}_{11} \mathrm{H}_{16} \mathrm{O}_{5} \mathrm{Na}^{+}\right]$: 251.0890, Found: 251.0883. 


\section{(2R,6R)-6-(4-methoxybenzyloxy)-2-methyl-2H-pyran-3(6H)-one (9):}

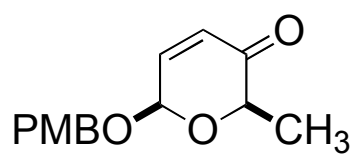

A $\mathrm{CH}_{2} \mathrm{Cl}_{2}(2 \mathrm{~mL})$ solution of tert-butyl (2S,6R)-5,6-dihydro-6-methyl-5-oxo-2H-pyran-2-yl carbonate 6( $\beta$-D) $(2.28 \mathrm{~g}, 10 \mathrm{mmol})$ and 4-methoxybenzyl alcohol $(2.76 \mathrm{~g}, 20 \mathrm{~mL})$ was cooled to $0{ }^{\circ} \mathrm{C}, \mathrm{Pd}_{2}(\mathrm{DBA})_{3} \cdot \mathrm{CHCl}_{3}(260 \mathrm{mg}, 2.5 \mathrm{~mol} \%)$ and $\mathrm{PPh}_{3}(226 \mathrm{mg}, 10 \mathrm{~mol} \%)$ were added to the reaction mixture at $0{ }^{\circ} \mathrm{C}$. The reaction mixture was stirred at $0{ }^{\circ} \mathrm{C}$ for $2 \mathrm{~h}$. The reaction was quenched by adding $10 \mathrm{~mL}$ of satd. aq. $\mathrm{NaHCO}_{3}$, extracted three times with ether, dried over $\mathrm{Na}_{2} \mathrm{SO}_{4}$ and concentrated under reduced pressure. The crude product was purified using silica gel flash chromatography eluting with 5\% EtOAc/hexanes to give pyranone 9 (2.32 g, $9.5 \mathrm{mmol}$, 95\%) as a yellow oil: $R_{f}(10 \%$ EtOAc/hexanes $)=0.15 ;[\alpha]_{\mathrm{D}}^{21}=-22.4\left(c=1.0, \mathrm{CH}_{2} \mathrm{Cl}_{2}\right)$; IR (thin film, $\left.\mathrm{cm}^{-1}\right) 2938,2837,1696,1513,1246,1054,1008,818,802 ;{ }^{1} \mathrm{H} \mathrm{NMR}\left(600 \mathrm{MHz}, \mathrm{CDCl}_{3}\right) \delta$ $7.23(\mathrm{~d}, J=8.4,2 \mathrm{H}), 6.88(\mathrm{~d}, J=8.4,2 \mathrm{H}), 6.83(\mathrm{dd}, J=10.2,1.2,1 \mathrm{H}), 6.03(\mathrm{~d}, J=10.2,1 \mathrm{H})$, $5.29(\mathrm{~d}, J=1.2,1 \mathrm{H}), 4.79(\mathrm{~d}, J=11.4,1 \mathrm{H}), 4.54(\mathrm{~d}, J=11.4,1 \mathrm{H}), 4.15(\mathrm{q}, J=6.6,1 \mathrm{H}), 3.71(\mathrm{~s}$, 3H), $1.45(\mathrm{~d}, J=6.6,3 \mathrm{H}) ;{ }^{13} \mathrm{C} \mathrm{NMR}\left(150 \mathrm{MHz}, \mathrm{CDCl}_{3}\right) \delta 196.5,159.2,146.5,129.5,128.7$, 127.7, 113.6, 93.9, 74.9, 69.5, 54.9, 16.9; CIHRMS Calcd for $\left[\mathrm{C}_{14} \mathrm{H}_{16} \mathrm{O}_{4} \mathrm{H}\right]^{+}$: 249.1127. Found 249.1122. 


\section{(2R,6R)-6-(4-methoxybenzyloxy)-3,6-dihydro-2-methyl-2H-pyran-3-ol (10a/b):}

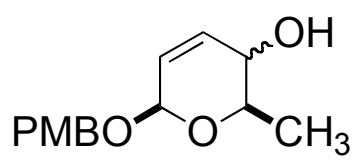

Pyranone 9 was dissolved in $24 \mathrm{~mL} \mathrm{CH}_{2} \mathrm{Cl}_{2}$, resulting solution was cooled to $-78{ }^{\circ} \mathrm{C}, 24 \mathrm{~mL}$ of $0.4 \mathrm{M} \mathrm{CeCl}_{3}$ in methanol solution was added in a dropwise fashion, followed by adding $540 \mathrm{mg}$ of $\mathrm{NaBH}_{4}$. By TLC tracking, the reaction was done after $1.5 \mathrm{~h}$. The reaction mixture was diluted with $2 \mathrm{~mL}$ diethyl ether, then quenched with $2 \mathrm{~mL}$ water, extracted with 3 x $20 \mathrm{~mL}$ diethyl ether, dried over anhydrous sodium sulfate, and concentrated under reduced pressure. The crude product was purified using silica gel flash chromatography eluting with $80 \%$ EtOAc/Hexane to give allylic alcohol 10a/b as a mixture of diastereomers $(2.40 \mathrm{~g}, 9.5 \mathrm{mmol}, 99 \%)$ as a colorless oil: $R_{f}(30 \%$ EtOAc/hexanes $)=0.45 ;[\alpha]_{\mathrm{D}}^{21}=-58.5\left(c=1.0, \mathrm{CH}_{2} \mathrm{Cl}_{2}\right)$; IR (thin film, $\left.\mathrm{cm}^{-1}\right) 3421$, $2977,2871,1612,1513,1244,1172,1031,818,788$

10a ${ }^{1} \mathrm{H}$ NMR $\left(600 \mathrm{MHz}, \mathrm{CDCl}_{3}\right) \delta 7.26(\mathrm{~d}, J=8.4,2 \mathrm{H}), 6.85(\mathrm{~d}, J=8.4,2 \mathrm{H}), 6.11(\mathrm{ddd}, J=$ $10.2,5.4,1.8,1 \mathrm{H}), 5.81(\mathrm{~d}, J=10.2,1 \mathrm{H}), 5.09(\mathrm{~m}, 1 \mathrm{H}), 4.80(\mathrm{~d}, J=11.4,1 \mathrm{H}), 4.56(\mathrm{~d}, J=11.4$ $1 \mathrm{H}), 3.77(\mathrm{~s}, 3 \mathrm{H}), 3.68(\mathrm{~m}, 1 \mathrm{H}), 3.64(\mathrm{~m}, 1 \mathrm{H}), 2.00(\mathrm{~m}, 1 \mathrm{H}), 1.30(\mathrm{~d}, J=6.6,3 \mathrm{H})$;

10b ${ }^{1} \mathrm{H}$ NMR $\left(600 \mathrm{MHz}, \mathrm{CDCl}_{3}\right) \delta 7.26(\mathrm{~d}, J=8.4,2 \mathrm{H}), 6.85(\mathrm{~d}, J=8.4,2 \mathrm{H}), 5.92(\mathrm{~d}, J=10.2$, $1 \mathrm{H}), 5.75(\mathrm{~d}, J=10.2,1 \mathrm{H}), 5.09(\mathrm{~m}, 1 \mathrm{H}), 4.76(\mathrm{~d}, J=11.4,1 \mathrm{H}), 4.52(\mathrm{~d}, J=11.4,1 \mathrm{H}), 3.77(\mathrm{~s}$, $3 \mathrm{H}), 3.71(\mathrm{~m}, 1 \mathrm{H}), 3.68(\mathrm{~m}, 1 \mathrm{H}), 2.00(\mathrm{~m}, 1 \mathrm{H}), 1.35(\mathrm{~d}, J=6.6,3 \mathrm{H}) ;{ }^{13} \mathrm{C} \mathrm{NMR}(150 \mathrm{MHz}$, $\left.\mathrm{CDCl}_{3}\right)$ major isomer $\delta 159.3(2 \mathrm{C}), 131.2(2 \mathrm{C}), 129.7,129.6,113.8,96.7,71.5,69.6,68.4,64.8$, 55.3, 16.6; CIHRMS Calcd for $\left[\mathrm{C}_{14} \mathrm{H}_{18} \mathrm{O}_{4} \mathrm{Na}\right]^{+}$: 273.1103. Found 273.1100. 


\section{(2R,6R)-2-(4-methoxybenzyloxy)-3,6-dihydro-6-methyl-2H-pyran (11):}

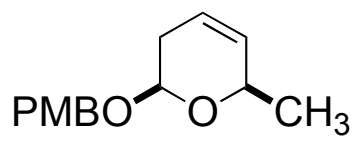

A flask charged with dry $N$-Methyl morpholine (NMM) $20 \mathrm{~mL}$, triphenyl phosphine $(6.86 \mathrm{~g}$, $30.36 \mathrm{mmol})$ was cooled to $-30{ }^{\circ} \mathrm{C}$ under argon atmosphere. Diethylazodicarboxylate $(4.35 \mathrm{~mL}$, $27.6 \mathrm{mmol})$ was added and the reaction was stirred for $5 \mathrm{~min}$, allylic alcohol $\mathbf{1 0 a} / \mathbf{b}(2.3 \mathrm{~g}, 9.2$ mmol) was added to in a $1 \mathrm{M}$ of NMM $(9.2 \mathrm{~mL})$, the resulting reaction mixture was stirred for 10 min, followed by addition of $o$-nitrobenzenesulfonyl hydrazide (NBSH) (5.99 g, $27.6 \mathrm{mmol})$. The reaction was stirred at $-30{ }^{\circ} \mathrm{C}$ for $2 \mathrm{~h}$ and was monitored by TLC. Upon consumption of $\mathbf{1 0 a} / \mathbf{b}$, the reaction was warmed to room temperature and stirred for another $2 \mathrm{~h}$. The reaction mixture was diluted with ether $(20 \mathrm{~mL})$ and was quenched with $10 \mathrm{~mL}$ of satd. aq. $\mathrm{NaHCO}_{3}$, extracted $(3 \times 50 \mathrm{~mL})$ with ether, dried over $\mathrm{Na}_{2} \mathrm{SO}_{4}$, and concentrated under reduced pressure. The crude product was purified using silica gel flash chromatography eluting with 95\% EtOAc/hexanes to give product $11(2.10 \mathrm{~g}, 8.7 \mathrm{mmol}, 95 \%)$ as a yellow oil. $R_{f}(20 \%$ EtOAc/hexanes $)=0.55 ;[\alpha]_{\mathrm{D}}^{21}=-106\left(c=1.0, \mathrm{CH}_{2} \mathrm{Cl}_{2}\right) ; \mathrm{IR}\left(\right.$ thin film, $\left.\mathrm{cm}^{-1}\right) 3034,2909,1612$, 1512, 1365, 1245, 1155, 1075, 1045, 879, 818; ${ }^{1} \mathrm{H}$ NMR $\left(600 \mathrm{MHz}, \mathrm{CDCl}_{3}\right) \delta 7.30(\mathrm{~d}, J=7.8$, 2H), $6.88(\mathrm{~d}, J=7.8,2 \mathrm{H}), 5.67$ (dddd, $J=9.6,2.4,1.2,1.2,1 \mathrm{H}), 5.58$ (dddd, $J=9.6,5.4,2.4,2.4$, $1 \mathrm{H}), 4.86(\mathrm{~d}, J=11.4,1 \mathrm{H}), 4.72(\mathrm{dd}, J=8.4,3.0,1 \mathrm{H}), 4.55(\mathrm{~d}, J=11.4,1 \mathrm{H}), 4.33(\mathrm{~m}, 1 \mathrm{H}), 3.78$ (s, 3H), $2.22(\mathrm{~m}, 1 \mathrm{H}), 2.13(\mathrm{~m}, 1 \mathrm{H}), 1.32(\mathrm{~d}, J=6.6,3 \mathrm{H}) ;{ }^{13} \mathrm{C} \mathrm{NMR}\left(150 \mathrm{MHz}, \mathrm{CDCl}_{3}\right) \delta 159.0$, 130.8, 129.8, 129.4, 122.3, 113.6, 97.3, 70.4, 69.2, 55.0, 30.8, 21.0; CIHRMS Calcd for $\left[\mathrm{C}_{14} \mathrm{H}_{18} \mathrm{O}_{3} \mathrm{Na}\right]^{+}:$257.1154. Found 257.1148. 
$(2 R, 3 S, 4 S, 6 R)-6-(4-m e t h o x y b e n z y l o x y)-2-m e t h y l-t e t r a h y d r o n-2 H$-pyran-3,4-diol (12):

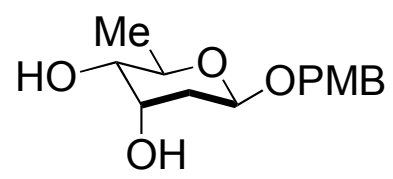

To a $t$-butanol, acetone $(4.3 \mathrm{~mL}$ each, $1: 1)$ solution of pyran $11(1 \mathrm{~g}, 4.3 \mathrm{mmol})$ at $0{ }^{\circ} \mathrm{C}$ was added a solution of $(50 \% \mathrm{w} / \mathrm{v})$ of $N$-methyl morpholine $N$-oxide / water $(4.3 \mathrm{~mL})$. Crystalline $\mathrm{OsO}_{4}(1.1 \mathrm{mg}, 1 \mathrm{~mol} \%)$ was added and the reaction was stirred for $12 \mathrm{~h}$. The reaction was quenched by adding EtOAc and satd. aq. $\mathrm{NaHCO}_{3}$. The organic layer was separated and concentrated. The crude product was purified by silica gel flash chromatography eluting with 50\% EtOAc/hexanes to give diol $12(0.97 \mathrm{~g}, 3.6 \mathrm{mmol}, 85 \%)$ as a colorless oil. $R_{f}(50 \%$ EtOAc/hexanes $)=0.20 ;[\alpha]_{\mathrm{D}}^{21}=-53.9\left(c=1.0, \mathrm{CH}_{2} \mathrm{Cl}_{2}\right) ; \mathrm{IR}\left(\right.$ thin film, $\left.\mathrm{cm}^{-1}\right) 3411,2933,1612$, 1513, 1245, 1161, 1032, 997, 819; ${ }^{1} \mathrm{H}$ NMR (600 MHz, $\left.\mathrm{CDCl}_{3}\right) \delta 7.23(\mathrm{~d}, J=8.4,2 \mathrm{H}), 6.83(\mathrm{~d}, J$ $=8.4,2 \mathrm{H}), 4.84(\mathrm{dd}, J=9.6,1.8,1 \mathrm{H}), 4.77(\mathrm{~d}, J=11.4,1 \mathrm{H}), 4.45(\mathrm{~d}, J=11.4,1 \mathrm{H}), 3.98(\mathrm{~d}, J=$ 3.0, 1H), $3.75(\mathrm{~s}, 3 \mathrm{H}), 3.68(\mathrm{dq}, J=9.0,6.0,1 \mathrm{H}), 3.22(\mathrm{dd}, J=3.6,1 \mathrm{H}), 3.05(\mathrm{~s}, 1 \mathrm{H}), 2.98(\mathrm{~s}$, $1 \mathrm{H}), 2.02(\mathrm{ddd}, \mathrm{J}=15,2.4,2.4,1 \mathrm{H}), 1.69(\mathrm{ddd}, J=14,11.4,3.0,1 \mathrm{H}), 1.28(\mathrm{~d}, J=6.6,3 \mathrm{H}) ;{ }^{13} \mathrm{C}$ NMR $\left(150 \mathrm{MHz}, \mathrm{CDCl}_{3}\right) \delta 159.1,129.6,129.5,113.7,96.6,72.8,70.1,69.4,67.7,55.1,37.5$, 18.0; CIHRMS Calcd for $\left[\mathrm{C}_{14} \mathrm{H}_{20} \mathrm{O}_{5} \mathrm{Na}\right]^{+}:$291.1208, Found 291.1205. 
$(2 R, 3 R, 4 R, 6 R)-6-(4-m e t h o x y b e n z y l o x y)-t e t r a h y d r o-3-h y d r o x y-2-m e t h y l-2 H-p y r a n-4-y l \quad 4-$ nitrobenzoate (13):

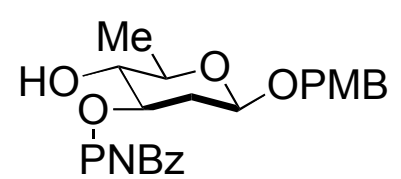

A THF $(16 \mathrm{~mL})$ solution of diol $12(920 \mathrm{mg}, 3.43 \mathrm{mmol})$ at $0{ }^{\circ} \mathrm{C}$ was added $\mathrm{PPh}_{3}(1.16 \mathrm{~g}, 5.15$ mmol) and p-nitrobenzoic acid (1.15 g, $6.87 \mathrm{mmol})$, DIAD (1.11 g, $5.49 \mathrm{mmol})$ was added dropwise and the reaction mixture was warmed up to room temperature and stirred for three days. The reaction mixture was diluted with $50 \mathrm{~mL}$ EtOAc, quenched with $40 \mathrm{~mL}$ of satd. aq. $\mathrm{NaHCO}_{3}$, extracted ( $3 \times 50 \mathrm{~mL})$ with ether, dried over $\mathrm{Na}_{2} \mathrm{SO}_{4}$, and concentrated under reduced pressure. The crude product was purified using silica gel flash chromatography eluting with 15\% EtOAc/Hexanes to give nitrobenzoate $13(1.00 \mathrm{~g}, 2.4 \mathrm{mmol}, 70 \%)$ as a yellow solid. $R_{f}(30 \%$ EtOAc/hexanes $)=0.40 ; \mathrm{mp}: 38-40{ }^{\circ} \mathrm{C} ;[\alpha]^{21}=-40.4\left(c=1.0, \mathrm{CH}_{2} \mathrm{Cl}_{2}\right) ; \mathrm{IR}\left(\right.$ thin film, $\left.\mathrm{cm}^{-1}\right) 3477$, 2939, 1722, 1609, 1513, 1347, 1269, 1166, 1100, 987; ${ }^{1} \mathrm{H}$ NMR $\left(600 \mathrm{MHz}, \mathrm{CDCl}_{3}\right) \delta 8.15(\mathrm{~d}, J$ $=9.0,2 \mathrm{H}), 8.10(\mathrm{~d}, J=9.0,2 \mathrm{H}), 7.21(\mathrm{~d}, J=8.4,2 \mathrm{H}), 6.82(\mathrm{~d}, J=8.4,2 \mathrm{H}), 5.02(\mathrm{ddd}, J=11.4$, $8.4,4.8,1 \mathrm{H}), 4.78(\mathrm{~d}, J=11.4,1 \mathrm{H}), 4.61(\mathrm{dd}, J=10.2,2.4,1 \mathrm{H}), 4.51(\mathrm{~d}, J=11.4,1 \mathrm{H}), 3.74(\mathrm{~s}$, $3 \mathrm{H}), 3.36(\mathrm{dq}, J=9.0,6.0,1 \mathrm{H}), 3.41(\mathrm{dd}, J=9.0,9.0,1 \mathrm{H}), 2.93(\mathrm{~s}, 1 \mathrm{H}), 2.35(\mathrm{ddd}, J=12.6,5.4$, $1.8,1 \mathrm{H}), 1.78(\mathrm{ddd}, J=12,12,9.6,1 \mathrm{H}), 1.19(\mathrm{~d}, J=6.6,3 \mathrm{H}) ;{ }^{13} \mathrm{C} \mathrm{NMR}\left(150 \mathrm{MHz}, \mathrm{CDCl}_{3}\right) \delta$ 164.5 (2C), 159.1 (2C), 150.4 (2C), 135.0 (2C), 130.6, 129.4, 129.1, 123.3, 113.7, 97.3, 75.4, 74.5, 71.8, 70.0, 55.0, 36.3, 17.7; CIHRMS Calcd for $\left[\mathrm{C}_{21} \mathrm{H}_{23} \mathrm{NO}_{8} \mathrm{Na}\right]^{+}$: 440.1321, Found 440.1317 . 


\section{$(2 R, 3 R, 4 R, 6 R)-3-((2 R, 6 S)-5,6-d i h y d r o-6-m e t h y l-5-0 x 0-2 H-p y r a n-2-y l o x y)-6-(4-$}

methoxybenzyloxy)-tetrahydro-2-methyl-2H-pyran-4-yl 4-nitrobenzoate (14):

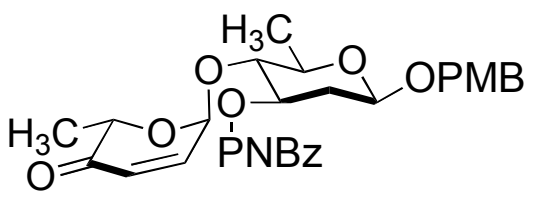

A $\mathrm{CH}_{2} \mathrm{Cl}_{2}(1.0 \mathrm{~mL})$ solution of Boc pyranone 5( $\left.\alpha-\mathrm{L}\right)(2.62 \mathrm{~g}, 11.5 \mathrm{mmol})$ and alcohol 13 (960 mg, $2.3 \mathrm{mmol})$ was cooled to $0{ }^{\circ} \mathrm{C} . \mathrm{Pd}_{2}(\mathrm{DBA})_{3} \cdot \mathrm{CHCl}_{3}(60 \mathrm{mg}, 2.5 \mathrm{~mol} \%)$ and $\mathrm{PPh}_{3}(52 \mathrm{mg}, 10$ mol\%) was added to the reaction mixture at $0{ }^{\circ} \mathrm{C}$. The reaction mixture was stirred at room temperature for $8 \mathrm{~h}$. The reaction mixture was quenched with $10 \mathrm{~mL}$ of satd. aq. $\mathrm{NaHCO}_{3}$, extracted $(3 \times 10 \mathrm{~mL})$ with $\mathrm{Et}_{2} \mathrm{O}$, dried over $\mathrm{Na}_{2} \mathrm{SO}_{4}$ and concentrated under reduced pressure. The crude product was purified using silica gel flash chromatography eluting with $20 \%$ EtOAc/hexanes to give pyranone $14(1.18 \mathrm{~g}, 2.24 \mathrm{mmol}, 98 \%)$ as a yellow solid: $R_{f}(30 \%$ EtOAc/hexanes $)=0.40 ; \mathrm{mp}: 52-54{ }^{\circ} \mathrm{C} ;[\alpha]_{\mathrm{D}}^{21}=-87.4\left(c=1.0, \mathrm{CH}_{2} \mathrm{Cl}_{2}\right) ;$ IR (thin film, $\left.\mathrm{cm}^{-1}\right)$ 2937, 1723, 1697, 1609, 1527, 1514, 1272, 1101, 979, 832; ${ }^{1} \mathrm{H}$ NMR (600 MHz, $\left.\mathrm{CDCl}_{3}\right) \delta 8.26$ $(\mathrm{d}, J=8.4,2 \mathrm{H}), 8.18(\mathrm{~d}, J=8.4,2 \mathrm{H}), 7.24(\mathrm{~d}, J=8.4,2 \mathrm{H}), 6.85(\mathrm{~d}, J=8.4,2 \mathrm{H}), 6.75(\mathrm{dd}, J=$ $10.2,3.6,1 \mathrm{H}), 5.97(\mathrm{~d}, J=10.2,1 \mathrm{H}), 5.30(\mathrm{~d}, J=3.6,1 \mathrm{H}), 5.26(\mathrm{ddd}, J=11.4,9.0,6.01 \mathrm{H}), 4.81$ $(\mathrm{d}, J=11.4,1 \mathrm{H}), 4.66(\mathrm{~d}, J=9.6,1 \mathrm{H}), 4.53(\mathrm{~d}, J=11.4,1 \mathrm{H}), 4.29(\mathrm{q}, J=6.6,1 \mathrm{H}), 3.77(\mathrm{~s}, 3 \mathrm{H})$, $3.62(\mathrm{dd}, J=9.0,9.0,1 \mathrm{H}), 3.47(\mathrm{dq}, J=9.0,6.6,1 \mathrm{H}), 2.38(\mathrm{dd}, J=12.6,5.4,1 \mathrm{H}), 1.80(\mathrm{ddd}, J=$ $12.6,12,12,1 \mathrm{H}), 1.41(\mathrm{~d}, J=6.6,3 \mathrm{H}), 0.88(\mathrm{~d}, J=6.6,3 \mathrm{H}) ;{ }^{13} \mathrm{C} \mathrm{NMR}\left(150 \mathrm{MHz}, \mathrm{CDCl}_{3}\right) \delta$ $196.3,163.9,159.4,150.6,142.5,135.4,130.7,129.6,129.1,126.8,123.5,113.9,97.3,94.4$ 82.6, 73.2, 71.0, 71.0, 70.2, 55.2, 36.7, 18.3, 15.0; CIHRMS Calcd for $\left[\mathrm{C}_{27} \mathrm{H}_{29} \mathrm{NO}_{10} \mathrm{Na}\right]^{+}$: 550.1689, Found 550.1690. 
$(2 R, 3 R, 4 R, 6 R)-3-((2 R, \quad 5 R, \quad 6 S)-5,6-d i h y d r o-5-h y d r o x y-6-m e t h y l-2 H-p y r a n-2-y l o x y)-6-(4-$ methoxybenzyloxy)-tetrahydro-2-methyl-2H-pyran-4-yl 4-nitrobenzoate (15):

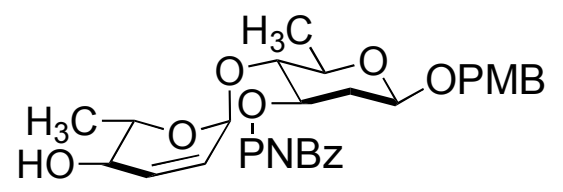

Pyranone 14 (1.14 g, $2.2 \mathrm{mmol})$ was dissolved in $5.38 \mathrm{~mL} \mathrm{CH}_{2} \mathrm{Cl}_{2}$, resulting solution was cooled to $-78^{\circ} \mathrm{C}, 5.38 \mathrm{~mL}$ of $0.4 \mathrm{M} \mathrm{CeCl}_{3}$ in methanol solution was added dropwise, followed by the addition of $123 \mathrm{mg}$ of $\mathrm{NaBH}_{4}$. By TLC tracking, the reaction was completed after $1.5 \mathrm{~h}$. The reaction mixture was diluted with $10 \mathrm{~mL}$ diethyl ether, and quenched with $2 \mathrm{~mL}$ water. Extraction by $3 \times 50 \mathrm{~mL}$ diethyl ether, dried over $\mathrm{Na}_{2} \mathrm{SO}_{4}$ and concentrated under reduced pressure to give allylic alcohol $15(1.11 \mathrm{~g}, 2.10 \mathrm{mmol}, 97 \%)$ as a white solid. $R_{f}(30 \%$ EtOAc/hexanes $)=0.20 ; \mathrm{mp}: 159.5-160.5^{\circ} \mathrm{C} ;[\alpha]_{\mathrm{D}}^{21}=-114.8\left(c=1.0, \mathrm{CH}_{2} \mathrm{Cl}_{2}\right) ; \mathrm{IR}$ (thin film,

$\left.\mathrm{cm}^{-1}\right) 3384,1718,1527,1513,1282,1104,996,717 ;{ }^{1} \mathrm{H} \mathrm{NMR}\left(600 \mathrm{MHz}, \mathrm{CDCl}_{3}\right) \delta 8.26(\mathrm{~d}, J=$ $11.0,2 \mathrm{H}), 8.19(\mathrm{~d}, J=11.0,2 \mathrm{H}), 7.25(\mathrm{~d}, J=9.0,2 \mathrm{H}), 6.86(\mathrm{~d}, J=9.0,2 \mathrm{H}), 5.84(\mathrm{~d}, J=10.2$, $1 \mathrm{H}), 5.66$ (ddd, $J=10.2,2.4,2.4,1 \mathrm{H}), 5.21$ (ddd, $J=12.0,8.4,5.4,1 \mathrm{H}), 5.04(\mathrm{~d}, J=2.4,1 \mathrm{H})$, $4.81(\mathrm{~d}, J=11.4,1 \mathrm{H}), 4.62(\mathrm{dd}, J=9.6,2.4,1 \mathrm{H}), 4.53(\mathrm{~d}, J=11.4,1 \mathrm{H}), 3.79(\mathrm{~s}, 3 \mathrm{H}), 3.60(\mathrm{ddd}$, $J=9.0,9.0,1.8,1 \mathrm{H}), 3.53(\mathrm{dd}, J=9.0,9.0,1 \mathrm{H}), 3.46(\mathrm{dq}, J=9.0,6.0,1 \mathrm{H}), 3.42(\mathrm{dq}, J=9.0,6.0$, 1H), 2.36 (ddd, $J=12.6,5.4,1.8,1 \mathrm{H}), 1.80$ (ddd, $J=12.6,12,10.2,1 \mathrm{H}), 1.60$ (s, $1 \mathrm{H}), 1.41$ (d, $J$ $=6.6,3 \mathrm{H}), 0.81(\mathrm{~d}, J=6.6,3 \mathrm{H}) ;{ }^{13} \mathrm{C} \mathrm{NMR}\left(150 \mathrm{MHz}, \mathrm{CDCl}_{3}\right) \delta 164.0,159.4,150.5,135.8$, 133.2, 130.8, 129.7, 129.2, 126.2, 123.5, 113.9, 97.4, 95.5, 81.8, 73.4, 71.3, 70.2, 69.1, 68.6, 55.3, 36.7, 18.4, 17.6; CIHRMS Calcd for $\left[\mathrm{C}_{27} \mathrm{H}_{31} \mathrm{NO}_{10} \mathrm{Na}\right]^{+}$: 552.1846, Found 552.1841. 
$(2 R, 3 R, 4 R, 6 R)-3-((2 R, \quad 5 R, \quad 6 S)-5,6-d i h y d r o-5-(4-n i t r o b e n z o a t e)-6-m e t h y l-2 H$-pyran-2yloxy)-6-(4-methoxybenzyloxy)-tetrahydro-2-methyl-2H-pyran-4-yl 4-nitrobenzoate (16):

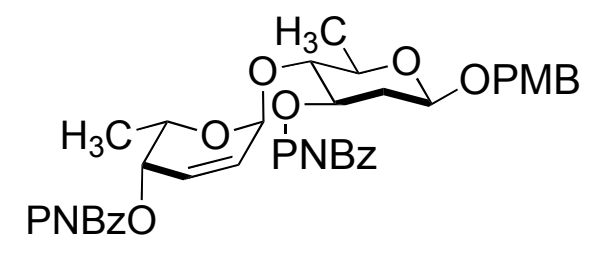

A THF $(0.7 \mathrm{~mL})$ solution of alcohol $15(106 \mathrm{mg}, 0.2 \mathrm{mmol})$ at $0{ }^{\circ} \mathrm{C}$ was added $\mathrm{PPh}_{3}(90.4 \mathrm{mg}$, $0.4 \mathrm{mmol})$ and $p$-nitrobenzoic acid (66.8 $\mathrm{mg}, 0.4 \mathrm{mmol})$, DIAD ( $80.9 \mathrm{mg}, 0.4 \mathrm{mmol})$ was added dropwise and the reaction mixture was warmed up to room temperature and stirred for three days. The reaction mixture was diluted with $5 \mathrm{~mL}$ EtOAc, quenched with $1 \mathrm{~mL}$ of satd. aq. $\mathrm{NaHCO}_{3}$, extracted $(3 \times 10 \mathrm{~mL})$ with methylene chloride, dried over $\mathrm{Na}_{2} \mathrm{SO}_{4}$, and concentrated under reduced pressure. The crude product was purified using silica gel flash chromatography eluting with $20 \% \mathrm{EtOAc} / \mathrm{Hexanes}$ to give product 16 (101 $\mathrm{mg}, 0.15 \mathrm{mmol}, 74 \%)$ as a light yellow solid. $R_{f}(30 \%$ EtOAc/hexanes $)=0.40 ; \mathrm{mp}: 174-175^{\circ} \mathrm{C} ;[\alpha]_{\mathrm{D}}^{21}=88.2\left(c=1.0, \mathrm{CH}_{2} \mathrm{Cl}_{2}\right) ; \mathrm{IR}$ (thin film, $\left.\mathrm{cm}^{-1}\right) 2930,1723,1609,1519,1342,1266,1069,1040,987,834,754 ;{ }^{1} \mathrm{H}$ NMR (600 MHz, $\left.\mathrm{CDCl}_{3}\right) \delta 8.22(\mathrm{~d}, J=9,2 \mathrm{H}), 8.17(\mathrm{~d}, J=9,2 \mathrm{H}), 8.16(\mathrm{~d}, J=9,2 \mathrm{H}), 8.02(\mathrm{~d}, J=9,2 \mathrm{H}), 7.20(\mathrm{~d}$, $J=9.0,2 \mathrm{H}), 6.81(\mathrm{~d}, J=9.0,2 \mathrm{H}), 6.06(\mathrm{dd}, J=10.2,5.4,1 \mathrm{H}), 5.96(\mathrm{dd}, J=10.2,3.0,1 \mathrm{H}), 5.21$ (ddd, $J=12.0,9.0,5.41 \mathrm{H}), 5.15(\mathrm{~d}, J=3,1 \mathrm{H}), 4.91(\mathrm{dd} \mathrm{J}=9.6,2.4,1 \mathrm{H}), 4.76(\mathrm{~d}, J=11.4,1 \mathrm{H})$, $4.58(\mathrm{dd} \mathrm{J}=9.6,1.8,1 \mathrm{H}), 4.49(\mathrm{~d}, J=11.4,1 \mathrm{H}), 4.03(\mathrm{dq}, J=6.6,3,1 \mathrm{H}), 4.03(\mathrm{dq}, J=9.0,6.2$ 1H), 3.74 (s, 3H), 3.55 (dd, $J=8.4,8.4,1 \mathrm{H}), 2.32(\mathrm{ddd}, J=12,6.0,1.8,1 \mathrm{H}), 1.79$ (ddd, $J=15$, 9.6, 9.6, $1 \mathrm{H}), 1.38(\mathrm{~d}, J=6.6,3 \mathrm{H}), 0.71(\mathrm{~d}, J=6.6,3 \mathrm{H}) ;{ }^{13} \mathrm{C}\left(150 \mathrm{MHz}, \mathrm{CDCl}_{3}\right) 164.1,164.0$, $159.5,150.7,150.6,135.7,135.0,130.9,130.7,130.6,129.7,129.2,125.1,123.5,123.5,113.9$, 
97.3, 95.3, 81.8, 73.2, 71.3, 70.2, 66.1, 65.3, 55.3, 36.7, 18.5, 15.8; CIHRMS Calcd for $\left[\mathrm{C}_{34} \mathrm{H}_{34} \mathrm{~N}_{2} \mathrm{O}_{13} \mathrm{Na}\right]^{+}:$701.1959, Found 701.1961. 


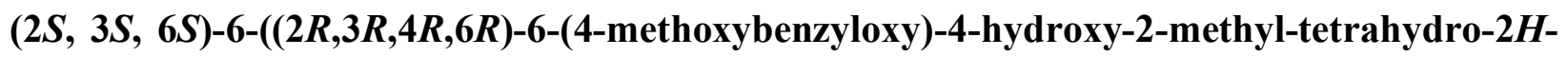
pyran-3-yloxy)-2-methyl-3,6-dihydro-2H-pyran-3-ol (17):

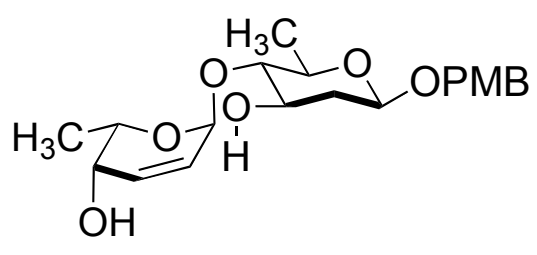

Bis-nitrobenzoate $16(723 \mathrm{mg}, 1.07 \mathrm{mmol})$ was dissolved in a mixed solvent of THF/ $\mathrm{H}_{2} \mathrm{O}(15$ $\mathrm{mL} / 3 \mathrm{~mL})$ at room temperature, $\mathrm{LiOH}(102 \mathrm{mg}, 4.28 \mathrm{mmol})$ was added and the reaction was stirred for $24 \mathrm{~h}$. The reaction was quenched by adding $5 \mathrm{~mL}$ of satd. aq. $\mathrm{NaHCO}_{3}$, extracted $(3 \mathrm{x}$ $50 \mathrm{~mL}$ ) with methylene chloride, dried over $\mathrm{Na}_{2} \mathrm{SO}_{4}$, and concentrated under reduced pressure. The crude product was purified using silica gel flash chromatography eluting with $30 \%$ EtOAc/hexanes to give product $17(324 \mathrm{mg}, 0.85 \mathrm{mmol}, 80 \%)$ as a white solid. $R_{f}(50 \%$ EtOAc/hexanes $)=0.15 ; \mathrm{mp}: 118-119^{\circ} \mathrm{C} ;[\alpha]_{\mathrm{D}}^{21}=14.0\left(c=1.0, \mathrm{CH}_{2} \mathrm{Cl}_{2}\right) ; \mathrm{IR}$ (thin film, $\left.\mathrm{cm}^{-1}\right)$ 3420, 3390, 2922, 1611, 1513, 1456, 1360, 1246, 1094, 1000, 897, 823; ${ }^{1} \mathrm{H}$ NMR (600 MHz, $\left.\mathrm{CDCl}_{3}\right) \delta 7.27(\mathrm{~d}, J=8.4,2 \mathrm{H}), 6.87(\mathrm{~d}, J=8.4,2 \mathrm{H}), 6.22(\mathrm{dd}, J=10.2,5.4,1.2,1 \mathrm{H}), 5.87(\mathrm{dd}, J$ $=10.2,3.6,1 \mathrm{H}), 5.07(\mathrm{dd}, J=2.4,0.6,1 \mathrm{H}), 4.82(\mathrm{~d}, J=12.0,1 \mathrm{H}), 4.60(\mathrm{~m}, 1 \mathrm{H}), 4.53(\mathrm{~d}, J=$ $12.0,1 \mathrm{H}), 4.52(\mathrm{dd}, J=9.6,2.4,1 \mathrm{H}), 4.22(\mathrm{qd}, J=6.6,2.4,1 \mathrm{H}), 3.80(\mathrm{~s}, 3 \mathrm{H}), 3.63(\mathrm{~m}, 1 \mathrm{H}), 3.60$ (ddd, $J=12.0,8.4,5.4,1 \mathrm{H}), 3.32(\mathrm{dq}, J=9,6.0,1 \mathrm{H}), 3.04(\mathrm{dd}, J=8.4,8.4,1 \mathrm{H}), 2.25$ (ddd, $J=$ 12.6, 5.4, 1.8, 1H), 1.67 (ddd, $J=12.6,12.0,9.6,1 \mathrm{H}), 1.51(\mathrm{~m}, 1 \mathrm{H}), 1.35(\mathrm{~d}, J=6.6,3 \mathrm{H}), 1.33$ $(\mathrm{d}, J=6.6,3 \mathrm{H}) ;{ }^{13} \mathrm{C} \mathrm{NMR}\left(150 \mathrm{MHz}, \mathrm{CDCl}_{3}\right) 159.3,130.3,129.6,129.5,127.2,113.8,98.1$, 96.6, 88.9, 70.4, 70.1, 70.0, 67.8, 63.5, 55.3, 38.2, 18.0, 15.9; CIHRMS Calcd for $\left[\mathrm{C}_{20} \mathrm{H}_{28} \mathrm{O}_{7} \mathrm{Na}\right]^{+}$: 403.1733, Found 403.1728. 


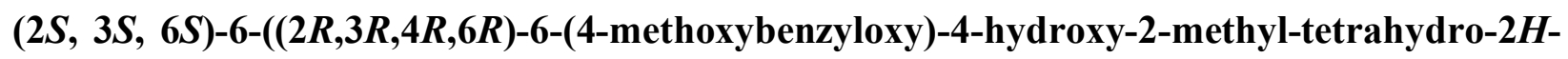
pyran-3-yloxy)-2-methyl-tetrahydro-2H-pyran-3-ol (18):

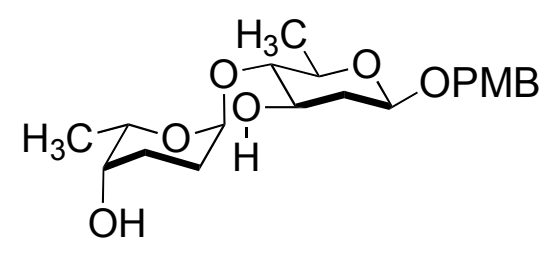

Allylic alcohol $17(415 \mathrm{mg}, 1.09 \mathrm{mmol})$ was dissolved in $\mathrm{CH}_{2} \mathrm{Cl}_{2}(11 \mathrm{~mL})$ at room temperature, then NBSH $(1.33 \mathrm{~g}, 6.55 \mathrm{mmol})$ and $\mathrm{Et}_{3} \mathrm{~N}(0.88 \mathrm{~g}, 8.74 \mathrm{mmol})$ were added while stirring. The reaction was tracked by TLC, after $12 \mathrm{~h}$, the reaction was quenched by adding $10 \mathrm{~mL}$ of satd. aq. $\mathrm{NaHCO}_{3}$, extracted $(3 \times 50 \mathrm{~mL})$ with methylene chloride, dried over $\mathrm{Na}_{2} \mathrm{SO}_{4}$, and concentrated under reduced pressure. The crude product was purified using silica gel flash chromatography eluting with $30 \%$ EtOAc/hexanes to give diol $18(420 \mathrm{mg}, 1.09 \mathrm{mmol}, 80 \%)$ as a yellow oil. $R_{f}$ $(50 \%$ EtOAc/hexanes $)=0.15 ;[\alpha]_{\mathrm{D}}^{21}=-98.2\left(c=1.0, \mathrm{CH}_{2} \mathrm{Cl}_{2}\right) ; \mathrm{IR}\left(\right.$ thin film, $\left.\mathrm{cm}^{-1}\right) 3390,2933$, $1612,1514,1443,1368,1246,1166,1114,1066,1011,940,818 ;{ }^{1} \mathrm{H}$ NMR $\left(600 \mathrm{MHz}, \mathrm{CDCl}_{3}\right) \delta$ $7.27(\mathrm{~d}, J=9.0,2 \mathrm{H}), 6.87(\mathrm{~d}, J=9.0,2 \mathrm{H}), 4.92(\mathrm{~d}, J=3,1 \mathrm{H}), 4.91(\mathrm{~d}, J=3,1 \mathrm{H}), 4.81(\mathrm{~d}, J=$ $11.4,1 \mathrm{H}), 4.79(\mathrm{~d}, J=1.2,1 \mathrm{H}), 4.52(\mathrm{~d}, J=11.4,1 \mathrm{H}), 4.50(\mathrm{dd}, J=10.2,2.4,1 \mathrm{H}), 3.79(\mathrm{~s}, 3 \mathrm{H})$, $4.14(\mathrm{qd}, J=6.6,1.2,1 \mathrm{H}), 3.62(\mathrm{~m}, 1 \mathrm{H}), 3.56(\mathrm{~m}, 1 \mathrm{H}), 3.31(\mathrm{dq}, J=9,6.0,1 \mathrm{H}), 2.98(\mathrm{dd}, J=8.4$, 8.4, 1H), 2.21 (ddd, $J=12.6,5.4,1.8,1 \mathrm{H}), 2.06(\mathrm{ddd}, J=13.8,13.8,3.6,3.6,1 \mathrm{H}), 1.98$ (ddd, $J=$ $13.8,13.8,3,3,1 \mathrm{H}), 1.76(\mathrm{ddd}, J=13.2,7.2,3.6,1 \mathrm{H}), 1.68-1.58(\mathrm{~m}, 2 \mathrm{H}), 1.32(\mathrm{~d}, J=6.6,3 \mathrm{H})$, $1.21(\mathrm{~d}, J=6.6,3 \mathrm{H}) ;{ }^{13} \mathrm{C} \mathrm{NMR}\left(150 \mathrm{MHz}, \mathrm{CDCl}_{3}\right) 159.3,129.7,129.5,113.8,99.6,98.0,88.7$, 70.4, 70.3, 69.9, 68.0, 67.1, 55.3, 38.2, 25.4, 24.2, 18.1, 16.9; CIHRMS Calcd for $\left[\mathrm{C}_{20} \mathrm{H}_{30} \mathrm{O}_{7} \mathrm{Na}\right]^{+}$: 405.1889, Found 405.1885. 


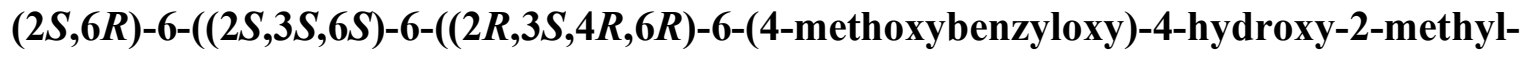

tetrahydro-2H-pyran-3-yloxy)-2-methyl-tetrahydro-2H-pyran-3-yloxy)-2-methyl-2H3(6H)-one (19):

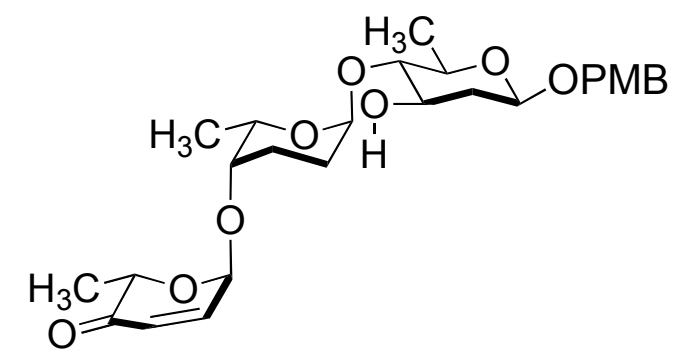

$\mathrm{A} \mathrm{CH}_{2} \mathrm{Cl}_{2}(0.1 \mathrm{~mL})$ solution of Boc pyranone $\mathbf{5}(\boldsymbol{\alpha}-\mathbf{L})(32.23 \mathrm{mg}, 0.14 \mathrm{mmol})$ and alcohol 18 (18 $\mathrm{mg}, 0.047 \mathrm{mmol})$ was cooled to $0{ }^{\circ} \mathrm{C} . \mathrm{Pd}_{2}(\mathrm{DBA})_{3} \cdot \mathrm{CHCl}_{3}(1.22 \mathrm{mg}, 2.5 \mathrm{~mol} \%)$ and $\mathrm{PPh}_{3}(1.06$ mg, $10 \mathrm{~mol} \%$ ) was added to the reaction mixture at $0{ }^{\circ} \mathrm{C}$. The reaction mixture was stirred at room temperature for $12 \mathrm{~h}$. The reaction mixture was quenched with $1 \mathrm{~mL}$ of satd. aq. $\mathrm{NaHCO}_{3}$, extracted ( $3 \times 5 \mathrm{~mL}$ ) with $\mathrm{CH}_{2} \mathrm{Cl}_{2}$, dried over $\mathrm{Na}_{2} \mathrm{SO}_{4}$ and concentrated under reduced pressure. The crude product was purified using silica gel flash chromatography eluting with $20 \%$ EtOAc/Hexanes to give pyranone $19(8 \mathrm{mg}, 0.016 \mathrm{mmol}, 35 \%)$ as a white solid along with $61 \%$ of recovered starting material $18(11 \mathrm{mg}, 0.029 \mathrm{mmol}): R_{f}(50 \%$ EtOAc/hexanes $)=0.50 ; \mathrm{mp}$ : $112-113{ }^{\circ} \mathrm{C} ;[\alpha]_{\mathrm{D}}^{21}=-16.7\left(c=1.0, \mathrm{CH}_{2} \mathrm{Cl}_{2}\right)$; IR (thin film, $\left.\mathrm{cm}^{-1}\right) 3417,2920,1698,1612,1514$, $1457,1371,1247,1067,1030,810 ;{ }^{1} \mathrm{H}$ NMR $\left(600 \mathrm{MHz}, \mathrm{CDCl}_{3}\right) \delta 7.21(\mathrm{~d}, J=9.0,2 \mathrm{H}), 6.82(\mathrm{~d}$, $J=9.0,2 \mathrm{H}), 6.79(\mathrm{dd}, J=10.2,3.6,1 \mathrm{H}), 6.03(\mathrm{~d}, J=10.2,1 \mathrm{H}), 5.16(\mathrm{~d}, J=3.6,1 \mathrm{H}), 4.87(\mathrm{~m}$ $1 \mathrm{H}), 4.75(\mathrm{~d}, J=11.4,1 \mathrm{H}), 4.48(\mathrm{q}, J=6.6,1 \mathrm{H}), 4.46(\mathrm{~d}, J=11.4,1 \mathrm{H}), 3.73(\mathrm{~s}, 3 \mathrm{H}), 4.68(\mathrm{~m}$, 1H), 4.45 (dd, $J=10,5,1 \mathrm{H}), 4.09$ (qd, $J=6.6,1.2,1 \mathrm{H}), 3.60(\mathrm{~m}, 1 \mathrm{H}), 3.50(\mathrm{~m}, 1 \mathrm{H}), 3.25(\mathrm{dq}, J$ $=9,6.0,1 \mathrm{H}), 2.91(\mathrm{dd}, \mathrm{J}=9,9,1 \mathrm{H}), 2.15(\mathrm{ddd}, J=12.6,5.4,1.8,1 \mathrm{H}), 2.02-1.95(\mathrm{~m}, 2 \mathrm{H}), 1.90-$ $1.85(\mathrm{~m}, 1 \mathrm{H}), 1.60-1.54(\mathrm{~m}, 2 \mathrm{H}), 1.35(\mathrm{~d}, J=6.6,3 \mathrm{H}), 1.30(\mathrm{~d}, J=6.6,3 \mathrm{H}), 1.16(\mathrm{~d}, J=6.6,3 \mathrm{H})$; 
${ }^{13} \mathrm{C}$ NMR (150 MHz, $\left.\mathrm{CDCl}_{3}\right)$ 196.5, 159.3, 142.7, 129.6, 129.5, 127.4, 113.8, 98.3, 98.0, 95.2, 88.6, 76.1, 70.6, 70.4, 70.3, 69.9, 67.7, 55.2, 38.2, 25.1, 24.3, 18.1, 16.9, 15.1; CIHRMS Calcd for $\left[\mathrm{C}_{26} \mathrm{H}_{36} \mathrm{O}_{9} \mathrm{Na}\right]^{+}:$515.2257, Found 515.2253. 


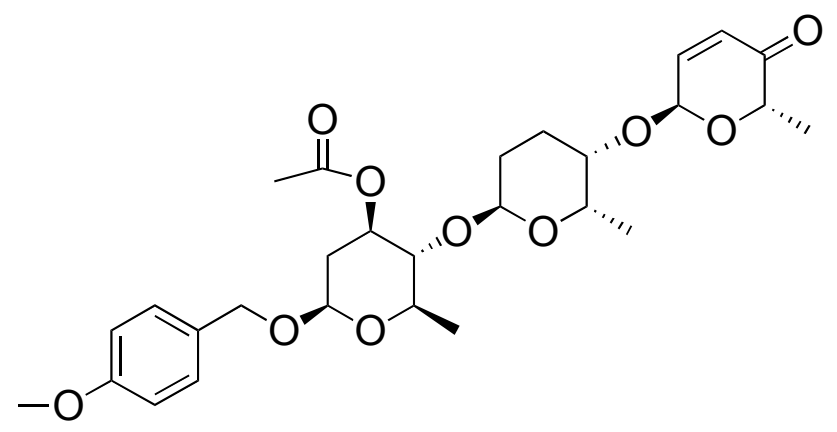

Alcohol 19 (75 mg, $0.152 \mathrm{mmol})$ was dissolved in $\mathrm{CH}_{2} \mathrm{Cl}_{2}(0.2 \mathrm{~mL})$ at room temperature, then acetic anhydride $(46.7 \mathrm{mg}, 0.457 \mathrm{mmol})$, pyridine $(42.1 \mathrm{mg}, 0.532 \mathrm{mmol})$ and a catalytic amount of DMAP were added in above order. The reaction mixture was stirred at room temperature for $12 \mathrm{~h}$. Reaction mixture was washed with $1 \mathrm{~mL} 1 \mathrm{M} \mathrm{HCl}$ solution, followed by washing with $2 \mathrm{~mL}$ of satd. aq. $\mathrm{NaHCO}_{3}$, extracted $(3 \times 5 \mathrm{~mL})$ with $\mathrm{CH}_{2} \mathrm{Cl}_{2}$, dried over $\mathrm{Na}_{2} \mathrm{SO}_{4}$ and concentrated under reduced pressure. The crude product was purified using silica gel flash chromatography eluting with $20 \%$ EtOAc/hexanes to give $20(67 \mathrm{mg}, 0.13 \mathrm{mmol}, 82 \%)$ as a yellow oil: $R_{f}(50 \%$ EtOAc/hexanes $)=0.60 ;[\alpha]_{\mathrm{D}}^{21}=-47.7\left(c=1.0, \mathrm{CH}_{2} \mathrm{Cl}_{2}\right) ;$ IR (thin film, $\left.\mathrm{cm}^{-1}\right) 2928,1733,1699$, $1613,1514,1363,1239,1122,1068,1030,962,734 ;{ }^{1} \mathrm{H}$ NMR $\left(600 \mathrm{MHz}, \mathrm{CDCl}_{3}\right) \delta 7.25(\mathrm{~d}, J=$ $8.3,2 \mathrm{H}), 6.87(\mathrm{~d}, J=8.3,2 \mathrm{H}), 6.86(\mathrm{dd}, J=10.1,3.5,1 \mathrm{H}), 6.09(\mathrm{~d}, J=10.2,1 \mathrm{H}), 5.22(\mathrm{~d}, J=$ 3.4, 1H), 4.95 (d, $J=2.1,1 \mathrm{H}), 4.88$ (ddd, $\mathrm{J}=9.0,8.0,2,1 \mathrm{H}), 4.80(\mathrm{~d}, J=11.6,1 \mathrm{H}), 4.54(\mathrm{dd}, J$ $=9.7,5.4,1 \mathrm{H}), 4.52(\mathrm{~d}, J=11.6,1 \mathrm{H}), 4.13(\mathrm{q}, J=7.1,1 \mathrm{H}), 4.00(\mathrm{qd}, J=6.6,1.2,1 \mathrm{H}), 3.81(\mathrm{~s}$, $3 \mathrm{H}), 3.58(\mathrm{ddd}, J=3.5,3.0,1.6,1 \mathrm{H}), 3.36(\mathrm{dd}, J=8.0,7.0,1 \mathrm{H}), 3.36(\mathrm{dq}, J=7,6.6,1 \mathrm{H}), 2.27$ (ddd, $J=12.5,5.4,2.0,1 \mathrm{H}), 2.01$ (ddd, $J=13.0,3.5,2.9,0.7,1 \mathrm{H}), 2.01$ (s, 3H), 1.96 (ddd, $J=$ 
$13.1,3.5,3.3,0.7,1 \mathrm{H}), 1.89$ (ddd, $J=13.1,3.8,3.5,3.0,1 \mathrm{H}), 1.63$ (ddd, $J=12.5,9.7,9,1 \mathrm{H}$ ), $1.55(\mathrm{ddd}, J=13.0,3.8,3.3,1.2,1 \mathrm{H}), 1.37$ (d, $J=6.8,3 \mathrm{H}), 1.35(\mathrm{~d}, J=6.6,3 \mathrm{H}), 1.16(\mathrm{~d}, J=6.6$, $3 \mathrm{H}) ;{ }^{13} \mathrm{C} \mathrm{NMR}\left(150 \mathrm{MHz}, \mathrm{CDCl}_{3}\right)$ 196.7, 170.5, 159.4, 143.0, 129.6, 129.3, 127.3, 113.8, 98.2, $97.4,95.3,80.5,76.6,72.2,71.5,70.5,70.1,66.6,55.3,36.7,24.8,24.2,21.3,18.4,17.1,15.1$; CIHRMS Calcd for $\left[\mathrm{C}_{28} \mathrm{H}_{38} \mathrm{O}_{10} \mathrm{Na}\right]^{+}: 557.2363$, Found 557.2358. 
acetate (43):

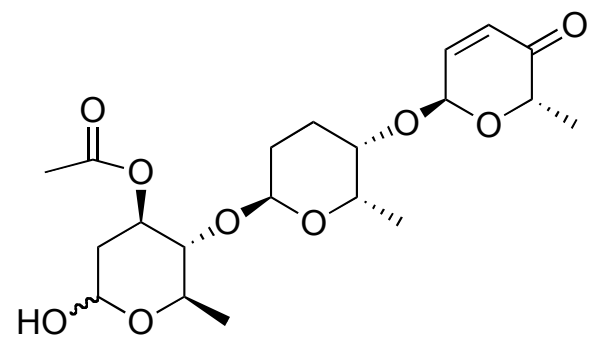

PMB ether $20(100 \mathrm{mg}, 0.187 \mathrm{mmol})$ was dissolved in $\mathrm{CH}_{2} \mathrm{Cl}_{2}(0.2 \mathrm{~mL})$ and water $(0.1 \mathrm{~mL})$ at 0 ${ }^{\circ} \mathrm{C}$, then excess DDQ $(85 \mathrm{mg}, 0.374 \mathrm{mmol})$ was added. The reaction mixture was stirred at $0{ }^{\circ} \mathrm{C}$ for $5 \mathrm{~h}$, at which time the reaction was filtered to remove precipitates, and washed with $2 \mathrm{~mL}$ of satd. aq. $\mathrm{NaHCO}_{3}$. Resulting solution was extracted $(3 \times 5 \mathrm{~mL})$ with $\mathrm{CH}_{2} \mathrm{Cl}_{2}$, dried over $\mathrm{Na}_{2} \mathrm{SO}_{4}$ and concentrated under reduced pressure. The crude product was purified using silica gel flash chromatography eluting with $20 \%$ EtOAc/hexanes to give $43(67 \mathrm{mg}, 0.13 \mathrm{mmol}, 82 \%)$ as a yellow oil:

\section{As an equilibrating mixture of stereo- and regio-isomers:}

$R_{f}(30 \%$ EtOAc/hexanes $)=0.20 ;[\alpha]_{\mathrm{D}}^{21}=40.7\left(c=1.0, \mathrm{CH}_{2} \mathrm{Cl}_{2}\right) ; \mathrm{IR}\left(\right.$ thin film, $\left.\mathrm{cm}^{-1}\right) 2928,1733$, $1699,1613,1514,1363,1239,1122,1068,1030,962,734 ;{ }^{1} \mathrm{H}$ NMR $\left(600 \mathrm{MHz}, \mathrm{CDCl}_{3}\right) \delta$ 6.87/6.86 (m, 1H), $6.09(\mathrm{~d}, J=10.2), 5.29(\mathrm{~s}) / 5.25(\mathrm{ddd}, \mathrm{J}=13.8,9.0,4.8), 5.21(\mathrm{~m}), 4.96$ (m)/4.91 (ddd)/4.87 (d), $4.55(\mathrm{~m}, 1 \mathrm{H}), 4.02(\mathrm{~m}, 2 \mathrm{H}), 3.58(\mathrm{~m}, 1 \mathrm{H}), 3.45(\mathrm{~m}) / 3.35(\mathrm{~m}), 3.16(\mathrm{~m})$ $2.66(\mathrm{~m}), 2.49(\mathrm{~m}), 2.38$ (ddd, $J=12.6,5.4,1.8), 2.25(\mathrm{ddd}, J=13.2,5.4,1.8), 2.15-1.80(\mathrm{~m})$, 2.06/2.05 (s, 3H), 1.73-1.4 (m), 1.4-1.16 (m); ${ }^{13} \mathrm{C}$ NMR (150 MHz, $\mathrm{CDCl}_{3}$ ) 196.84/196.78, 
170.5/170.4, $143.03 / 142.98, \quad 127.3,98.3 / 98.2,95.4 / 95.3,93.43 / 93.39,91.39 / 91.37,81.0$ 80.2,72.0/ 71.7, 70.6/70.2, 67.3/66.6, 38.1/35.6, 29.8, 24.8, 24.3, 21.4/21.3, 18.4, 17.2, 15.1; CIHRMS Calcd for $\left[\mathrm{C}_{20} \mathrm{H}_{30} \mathrm{NaO}_{9}\right]^{+}: 437.8$, Found 437.1786. 
(2S,6S)-6-(4-methoxybenzyloxy)-2-methyl-2H-pyran-3(6H)-one (ent-9): $:^{\dagger \dagger}$

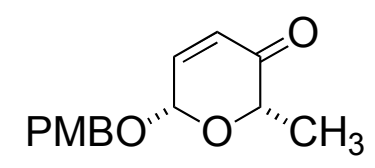

A $\mathrm{CH}_{2} \mathrm{Cl}_{2}(10 \mathrm{~mL})$ solution of tert-butyl $(2 \mathrm{~S}, 6 R)$-5,6-dihydro-6-methyl-5-oxo-2H-pyran-2-yl carbonate 6( $\beta$-D) $(11.4 \mathrm{~g}, 50 \mathrm{mmol})$ and 4-methoxybenzyl alcohol (13.8 g, $100 \mathrm{~mL})$ was cooled to $0{ }^{\circ} \mathrm{C}, \mathrm{Pd}_{2}(\mathrm{DBA})_{3} \cdot \mathrm{CHCl}_{3}(260 \mathrm{mg}, 1.0 \mathrm{~mol} \%)$ and $\mathrm{PPh}_{3}(226 \mathrm{mg}, 2 \mathrm{~mol} \%)$ were added to the reaction mixture at $0{ }^{\circ} \mathrm{C}$. The reaction mixture was stirred at $0{ }^{\circ} \mathrm{C}$ for $2 \mathrm{~h}$, and was quenched by adding $50 \mathrm{~mL}$ of satd. aq. $\mathrm{NaHCO}_{3}$. Resulting solution was extracted three times with ether, dried over $\mathrm{Na}_{2} \mathrm{SO}_{4}$ and concentrated under reduced pressure. The crude product was purified using silica gel flash chromatography eluting with 5\% EtOAc/hexanes to give pyranone ent-9 $(12.1 \mathrm{~g}, 50 \mathrm{mmol}, 99 \%)$ as a yellow oil: $R_{f}(10 \%$ EtOAc/hexanes $)=0.15 ;[\alpha]_{\mathrm{D}}^{21}=22.9(c=1.0$, $\mathrm{CH}_{2} \mathrm{Cl}_{2}$ ); IR (thin film, $\mathrm{cm}^{-1}$ ) 2938, 2837, 1696, 1513, 1246, 1054, 1008, 818, 802; ${ }^{\mathrm{H}} \mathrm{NMR}(600$ $\left.\mathrm{MHz}, \mathrm{CDCl}_{3}\right) \delta 7.23(\mathrm{~d}, J=8.4,2 \mathrm{H}), 6.88(\mathrm{~d}, J=8.4,2 \mathrm{H}), 6.83(\mathrm{dd}, J=10.2,1.2,1 \mathrm{H}), 6.03(\mathrm{~d}, J$ $=10.2,1 \mathrm{H}), 5.29(\mathrm{~d}, J=1.2,1 \mathrm{H}), 4.79(\mathrm{~d}, J=11.4,1 \mathrm{H}), 4.54(\mathrm{~d}, J=11.4,1 \mathrm{H}), 4.15(\mathrm{q}, J=6.6$, 1H), $3.71(\mathrm{~s}, 3 \mathrm{H}), 1.45(\mathrm{~d}, J=6.6,3 \mathrm{H}) ;{ }^{13} \mathrm{C} \mathrm{NMR}\left(150 \mathrm{MHz}, \mathrm{CDCl}_{3}\right) \delta 196.5,159.2,146.5$, 129.5, 128.7, 127.7, 113.6, 93.9, 74.9, 69.5, 54.9, 16.9; CIHRMS Calcd for $\left[\mathrm{C}_{14} \mathrm{H}_{16} \mathrm{O}_{4} \mathrm{H}\right]^{+}$: 249.1127. Found 249.1122.

\footnotetext{
${ }^{\dagger \dagger}$ For compounds in the enantiomeric series only ${ }^{1} \mathrm{H}$ NMR, ${ }^{13} \mathrm{C}$ NMR and optical rotations were recorded.
} 
(2S,6S)-6-(4-methoxybenzyloxy)-3,6-dihydro-2-methyl-2H-pyran-3-ol $\left(\right.$ ent-10a/b): ${ }^{\dagger \dagger}$<smiles>C[C@@H]1O[C@@H](O[R5](C)(C)C)C=C[C@H]1O</smiles>

Pyranone 9 (12 g, $50 \mathrm{mmol}$ ) was dissolved in $100 \mathrm{~mL} \mathrm{CH}_{2} \mathrm{Cl}_{2}$, and resulting solution was cooled to $-78{ }^{\circ} \mathrm{C} .100 \mathrm{~mL}$ of $0.4 \mathrm{M} \mathrm{CeCl}_{3}$ in methanol solution was added in a dropwise fashion, followed by adding $1 \mathrm{~g}$ of $\mathrm{NaBH}_{4}$. By TLC tracking, the reaction was done after $1.5 \mathrm{~h}$. The reaction mixture was diluted with $10 \mathrm{~mL}$ diethyl ether, and quenched with $10 \mathrm{~mL}$ water. Resulting solution was extracted with 3 x $20 \mathrm{~mL}$ diethyl ether, dried over anhydrous sodium sulfate, and concentrated under reduced pressure. The crude product was purified using silica gel flash chromatography eluting with $80 \%$ EtOAc/Hexane to give allylic alcohol ent-10a/b as a mixture of diastereomers $(12.0 \mathrm{~g}, 49 \mathrm{mmol}, 99 \%)$ as a colorless oil: $R_{f}(30 \%$ EtOAc/hexanes $)=$ $0.45 ;[\alpha]_{\mathrm{D}}^{21}=59\left(c=1.0, \mathrm{CH}_{2} \mathrm{Cl}_{2}\right) ;$ IR (thin film, $\left.\mathrm{cm}^{-1}\right) 3421,2977,2871,1612,1513,1244$ $1172,1031,818,788$

10a ${ }^{1} \mathrm{H}$ NMR $\left(600 \mathrm{MHz}, \mathrm{CDCl}_{3}\right) \delta 7.26(\mathrm{~d}, J=8.4,2 \mathrm{H}), 6.85(\mathrm{~d}, J=8.4,2 \mathrm{H}), 6.11(\mathrm{ddd}, J=$ $10.2,5.4,1.8,1 \mathrm{H}), 5.81(\mathrm{~d}, J=10.2,1 \mathrm{H}), 5.09(\mathrm{~m}, 1 \mathrm{H}), 4.80(\mathrm{~d}, J=11.4,1 \mathrm{H}), 4.56(\mathrm{~d}, J=11.4$, 1H), $3.77(\mathrm{~s}, 3 \mathrm{H}), 3.68(\mathrm{~m}, 1 \mathrm{H}), 3.64(\mathrm{~m}, 1 \mathrm{H}), 2.00(\mathrm{~m}, 1 \mathrm{H}), 1.30(\mathrm{~d}, J=6,3 \mathrm{H}) ; 10 \mathrm{~b}{ }^{1} \mathrm{H}$ NMR $\left(600 \mathrm{MHz}, \mathrm{CDCl}_{3}\right) \delta 7.26(\mathrm{~d}, J=8.4,2 \mathrm{H}), 6.85(\mathrm{~d}, J=8.4,2 \mathrm{H}), 5.92(\mathrm{~d}, J=10.2,1 \mathrm{H}), 5.75(\mathrm{~d}, J$ $=10.2,1 \mathrm{H}), 5.09(\mathrm{~m}, 1 \mathrm{H}), 4.76(\mathrm{~d}, J=11.4,1 \mathrm{H}), 4.52(\mathrm{~d}, J=11.4,1 \mathrm{H}), 3.77(\mathrm{~s}, 3 \mathrm{H}), 3.71(\mathrm{~m}$, 1H), $3.68(\mathrm{~m}, 1 \mathrm{H}), 2.00(\mathrm{~m}, 1 \mathrm{H}), 1.35(\mathrm{~d}, J=6,3 \mathrm{H}) ;{ }^{13} \mathrm{C} \mathrm{NMR}\left(150 \mathrm{MHz}, \mathrm{CDCl}_{3}\right)$ major isomer $\delta 159.3(2 \mathrm{C}), 131.2(2 \mathrm{C}), 129.7,129.6,113.8,96.7,71.5,69.6,68.4,64.8,55.3,16.6$; CIHRMS Calcd for $\left[\mathrm{C}_{14} \mathrm{H}_{18} \mathrm{O}_{4} \mathrm{Na}\right]^{+}:$273.1103. Found 273.1100. 


\section{(2S,6S)-2-(4-methoxybenzyloxy)-3,6-dihydro-6-methyl-2H-pyran (ent-11): $:^{\dagger \dagger}$}

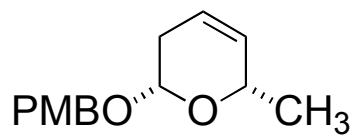

A flask charged with dry $N$-Methyl morpholine (NMM) $80 \mathrm{~mL}$, triphenyl phosphine $(27.5 \mathrm{~g}, 120$ mmol) was cooled to $-30{ }^{\circ} \mathrm{C}$ under argon atmosphere. Diethylazodicarboxylate $(20 \mathrm{~mL}, 150$ mmol) was added and the reaction was stirred for $5 \mathrm{~min}$, allylic alcohol (10 g, $41 \mathrm{mmol})$ was added in a solution of $1 \mathrm{M} \mathrm{NMM}(50 \mathrm{~mL})$, the resulting reaction mixture was stirred for $10 \mathrm{~min}$, followed by addition of $o$-nitrobenzenesulfonyl hydrazide (NBSH) (30 g). The reaction was stirred at $-30{ }^{\circ} \mathrm{C}$ for $2 \mathrm{~h}$ and monitored by TLC. Upon consumption of $\mathbf{1 0 a} / \mathbf{b}$, the reaction was warmed to room temperature and stirred for another $2 \mathrm{~h}$. The reaction mixture was diluted with ether $(100 \mathrm{~mL})$ and was quenched with $50 \mathrm{~mL}$ of satd. aq. $\mathrm{NaHCO}_{3}$, extracted $(3 \times 50 \mathrm{~mL})$ with ether, dried over $\mathrm{Na}_{2} \mathrm{SO}_{4}$, and concentrated under reduced pressure. The crude product was purified using silica gel flash chromatography eluting with 95\% EtOAc/hexanes to give ent-11 product $(9.10 \mathrm{~g}, 40 \mathrm{mmol}, 98 \%)$ as a yellow oil. $R_{f}(20 \%$ EtOAc/hexanes $)=0.55 ;[\alpha]_{\mathrm{D}}^{21}=107(c$ $=1.0, \mathrm{CH}_{2} \mathrm{Cl}_{2}$ ); IR (thin film, $\mathrm{cm}^{-1}$ ) 3034, 2909, 1612, 1512, 1365, 1245, 1155, 1075, 1045, 879, 818; ${ }^{1} \mathrm{H}$ NMR $\left(600 \mathrm{MHz}, \mathrm{CDCl}_{3}\right) \delta 7.30(\mathrm{~d}, J=7.8,2 \mathrm{H}), 6.88(\mathrm{~d}, J=7.8,2 \mathrm{H}), 5.67$ (dddd, $J=$ $9.6,2.4,1.2,1.2,1 \mathrm{H}), 5.58(\mathrm{dddd}, J=9.6,5.4,2.4,2.4,1 \mathrm{H}), 4.86(\mathrm{~d}, J=11.4,1 \mathrm{H}), 4.72(\mathrm{dd}, J=$ 8.4, 3.0, 1H), $4.55(\mathrm{~d}, J=11.4,1 \mathrm{H}), 4.33(\mathrm{~m}, 1 \mathrm{H}), 3.78(\mathrm{~s}, 3 \mathrm{H}), 2.22(\mathrm{~m}, 1 \mathrm{H}), 2.13(\mathrm{~m}, 1 \mathrm{H}), 1.32$ $(\mathrm{d}, J=7.2,3 \mathrm{H}) ;{ }^{13} \mathrm{C} \mathrm{NMR}\left(150 \mathrm{MHz}, \mathrm{CDCl}_{3}\right) \delta 159.0,130.8,129.8,129.4,122.3,113.6,97.3$, 70.4, 69.2, 55.0, 30.8, 21.0; CIHRMS Calcd for $\left[\mathrm{C}_{14} \mathrm{H}_{18} \mathrm{O}_{3} \mathrm{Na}\right]^{+}$: 257.1154. Found 257.1148. 
$(2 S, 3 R, 4 R, 6 S)-6-(4-m e t h o x y b e n z y l o x y)-2-m e t h y l-t e t r a h y d r o n-2 H$-pyran-3,4-diol $(e n t-12):^{\dagger \dagger}$

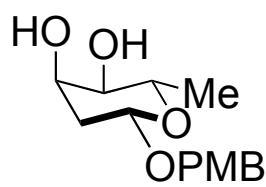

To a t-butanol/acetone $(25 \mathrm{~mL}$ each, 1:1) solution of pyran ent-11 (5 g, $22 \mathrm{mmol})$ at $0{ }^{\circ} \mathrm{C}$ was added a solution of $(50 \% \mathrm{w} / \mathrm{v})$ of $N$-methyl morpholine $N$-oxide / water $(25 \mathrm{~mL})$. Crystalline $\mathrm{OsO}_{4}(5 \mathrm{mg}, 5 \mathrm{~mol} \%)$ was added and the reaction was stirred for $12 \mathrm{~h}$. The reaction was quenched by adding EtOAc and satd. aq. $\mathrm{NaHCO}_{3}$. The organic layer was separated and concentrated. The crude product was purified using silica gel flash chromatography eluting with 50\% EtOAc/hexanes to give diol ent-12 (5.1 g, $19 \mathrm{mmol}, 86 \%)$ as a colorless oil. $R_{f}(50 \%$ EtOAc/hexanes $)=0.20 ;[\alpha]_{D}^{21}=53.5\left(c=1.0, \mathrm{CH}_{2} \mathrm{Cl}_{2}\right) ; \mathrm{IR}\left(\right.$ thin film, $\left.\mathrm{cm}^{-1}\right) 3411,2933,1612$, 1513, 1245, 1161, 1032, 997, 819; ${ }^{1} \mathrm{H}$ NMR (600 MHz, $\left.\mathrm{CDCl}_{3}\right) \delta 7.23(\mathrm{~d}, J=8.4,2 \mathrm{H}), 6.83(\mathrm{~d}, J$ $=8.4,2 \mathrm{H}), 4.84(\mathrm{dd}, J=9.6,1.8,1 \mathrm{H}), 4.77(\mathrm{~d}, J=11.4,1 \mathrm{H}), 4.45(\mathrm{~d}, J=11.4,1 \mathrm{H}), 3.98(\mathrm{~d}, J=$ 3.0, 1H), $3.75(\mathrm{~s}, 3 \mathrm{H}), 3.68(\mathrm{dq}, J=9.0,6.0,1 \mathrm{H}), 3.22(\mathrm{dd}, J=3.6,1 \mathrm{H}), 3.05(\mathrm{~s}, 1 \mathrm{H}), 2.98(\mathrm{~s}$, $1 \mathrm{H}), 2.02(\mathrm{ddd}, \mathrm{J}=15,2.4,2.4,1 \mathrm{H}), 1.69(\mathrm{ddd}, J=14,11.4,3.0,1 \mathrm{H}), 1.28(\mathrm{~d}, J=6.6,3 \mathrm{H}) ;{ }^{13} \mathrm{C}$ NMR $\left(150 \mathrm{MHz}, \mathrm{CDCl}_{3}\right) \delta 159.1,129.6,129.5,113.7,96.6,72.8,70.1,69.4,67.7,55.1,37.5$, 18.0; CIHRMS Calcd for $\left[\mathrm{C}_{14} \mathrm{H}_{20} \mathrm{O}_{5} \mathrm{Na}\right]^{+}:$291.1208, Found 291.1205. 
nitrobenzoate $\left(\right.$ ent-13): ${ }^{\dagger \dagger}$

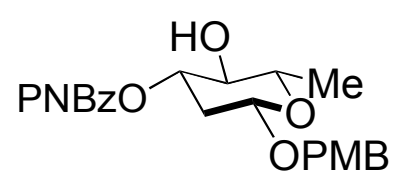

A THF $(16 \mathrm{~mL})$ solution of diol ent-12 $(5.0 \mathrm{~g}, 18.6 \mathrm{mmol})$ at $0{ }^{\circ} \mathrm{C}$ was added $\mathrm{PPh}_{3}(5.8 \mathrm{~g}, 26$ mmol), p-nitrobenzoic acid (5.8 g, $26 \mathrm{mmol})$, and DIAD (5.6 g, $28 \mathrm{mmol})$ was added dropwise. The reaction mixture was warmed up to room temperature and stirred for three days. The reaction mixture was diluted with $100 \mathrm{~mL}$ EtOAc, quenched with $100 \mathrm{~mL}$ of satd. aq. $\mathrm{NaHCO}_{3}$, extracted $(3 \times 50 \mathrm{~mL})$ with ether, dried over $\mathrm{Na}_{2} \mathrm{SO}_{4}$, and concentrated under reduced pressure. The crude product was purified using silica gel flash chromatography eluting with 15\% EtOAc/Hexanes to give nitrobenzoate ent-13 (4.98 g, $12 \mathrm{mmol}, 65 \%)$ as a yellow solid. $R_{f}(30 \%$ EtOAc/hexanes $)=0.40 ; \mathrm{mp}: 38-40{ }^{\circ} \mathrm{C} ;[\alpha]_{\mathrm{D}}^{21}=40.0\left(c=1.0, \mathrm{CH}_{2} \mathrm{Cl}_{2}\right)$; IR (thin film, $\left.\mathrm{cm}^{-1}\right) 3477$, 2939, 1722, 1609, 1513, 1347, 1269, 1166, 1100, 987; ${ }^{1} \mathrm{H}$ NMR $\left(600 \mathrm{MHz}, \mathrm{CDCl}_{3}\right) \delta 8.15(\mathrm{~d}, J$ $=9.0,2 \mathrm{H}), 8.10(\mathrm{~d}, J=9.0,2 \mathrm{H}), 7.21(\mathrm{~d}, J=8.4,2 \mathrm{H}), 6.82(\mathrm{~d}, J=8.4,2 \mathrm{H}), 5.02(\mathrm{ddd}, J=11.4$, $8.4,4.8,1 \mathrm{H}), 4.78(\mathrm{~d}, J=11.4,1 \mathrm{H}), 4.61(\mathrm{dd}, J=10.2,2.4,1 \mathrm{H}), 4.51(\mathrm{~d}, J=11.4,1 \mathrm{H}), 3.74(\mathrm{~s}$, $3 \mathrm{H}), 3.36(\mathrm{dq}, J=9.0,6.0,1 \mathrm{H}), 3.41(\mathrm{dd}, J=9.0,9.0,1 \mathrm{H}), 2.93(\mathrm{~s}, 1 \mathrm{H}), 2.35(\mathrm{ddd}, J=12.6,5.4$, $1.8,1 \mathrm{H}), 1.78(\mathrm{ddd}, J=12,12,9.6,1 \mathrm{H}), 1.19(\mathrm{~d}, J=6.6,3 \mathrm{H}) ;{ }^{13} \mathrm{C} \mathrm{NMR}\left(150 \mathrm{MHz}, \mathrm{CDCl}_{3}\right) \delta$ 164.5 (2C), 159.1 (2C), 150.4 (2C), 135.0 (2C), 130.6, 129.4, 129.1, 123.3, 113.7, 97.3, 75.4, 74.5, 71.8, 70.0, 55.0, 36.3, 17.7; CIHRMS Calcd for $\left[\mathrm{C}_{21} \mathrm{H}_{23} \mathrm{NO}_{8} \mathrm{Na}\right]^{+}$: 440.1321, Found 440.1317 . 
$(2 S, 3 S, 4 S, 6 S)-3-((2 R, 6 S)-5,6-d i h y d r o-6-m e t h y l-5-0 x 0-2 H-p y r a n-2-y l o x y)-6-(4-$

methoxybenzyloxy)-tetrahydro-2-methyl-2H-pyran-4-yl 4-nitrobenzoate (ent-14): ${ }^{\dagger \dagger}$

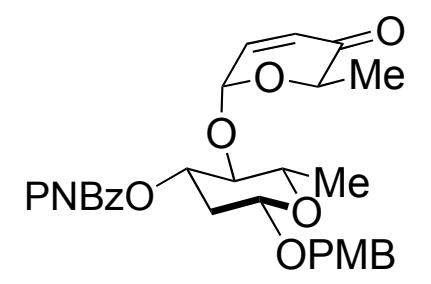

A $\mathrm{CH}_{2} \mathrm{Cl}_{2}(1.0 \mathrm{~mL})$ solution of Boc pyranone $\mathbf{5}(\boldsymbol{\alpha}-\mathrm{L})(5.0 \mathrm{~g}, 22 \mathrm{mmol})$ and alcohol ent-13 $(2.0$ $\mathrm{mg}, 4.8 \mathrm{mmol})$ was cooled to $0{ }^{\circ} \mathrm{C} . \mathrm{Pd}_{2}(\mathrm{DBA})_{3} \cdot \mathrm{CHCl}_{3}(60 \mathrm{mg}, 1.3 \mathrm{~mol} \%)$ and $\mathrm{PPh}_{3}(52 \mathrm{mg}, 5$ mol\%) were added to the reaction mixture at $0{ }^{\circ} \mathrm{C}$. After 8 hours stirring, the reaction mixture was quenched with $20 \mathrm{~mL}$ of satd. aq. $\mathrm{NaHCO}_{3}$, extracted $(3 \times 20 \mathrm{~mL})$ with $\mathrm{Et}_{2} \mathrm{O}$, dried over $\mathrm{Na}_{2} \mathrm{SO}_{4}$ and concentrated under reduced pressure. The crude product was purified using silica gel flash chromatography eluting with 20\% EtOAc/hexanes to give pyranone ent-14 (2.2 g, 4.2 mmol, $87 \%)$ as a yellow solid: $R_{f}(30 \%$ EtOAc/hexanes $)=0.40 ; \mathrm{mp}: 52-54^{\circ} \mathrm{C} ;[\alpha]_{\mathrm{D}}^{21}=88(c=$ 1.0, $\mathrm{CH}_{2} \mathrm{Cl}_{2}$ ); IR (thin film, $\mathrm{cm}^{-1}$ ) 2937, 1723, 1697, 1609, 1527, 1514, 1272, 1101, 979, 832; ${ }^{1} \mathrm{H}$ NMR (600 MHz, $\left.\mathrm{CDCl}_{3}\right) \delta 8.26(\mathrm{~d}, J=8.4,2 \mathrm{H}), 8.18(\mathrm{~d}, J=8.4,2 \mathrm{H}), 7.24(\mathrm{~d}, J=8.4,2 \mathrm{H}), 6.85$ $(\mathrm{d}, J=8.4,2 \mathrm{H}), 6.75(\mathrm{dd}, J=10.2,3.6,1 \mathrm{H}), 5.97(\mathrm{~d}, J=10.2,1 \mathrm{H}), 5.30(\mathrm{~d}, J=3.6,1 \mathrm{H}), 5.26$ (ddd, $J=11.4,9.0,6.01 \mathrm{H}), 4.81(\mathrm{~d}, J=11.4,1 \mathrm{H}), 4.66(\mathrm{~d}, J=9.6,1 \mathrm{H}), 4.53(\mathrm{~d}, J=11.4,1 \mathrm{H})$, $4.29(\mathrm{q}, J=6.6,1 \mathrm{H}), 3.77(\mathrm{~s}, 3 \mathrm{H}), 3.62(\mathrm{dd}, J=9.0,9.0,1 \mathrm{H}), 3.47(\mathrm{dq}, J=9.0,6.6,1 \mathrm{H}), 2.38$ (dd, $J=12.6,5.4,1 \mathrm{H}), 1.80(\mathrm{ddd}, J=12.6,12,12,1 \mathrm{H}), 1.41(\mathrm{~d}, J=6.6,3 \mathrm{H}), 0.88(\mathrm{~d}, J=6.6$, $3 \mathrm{H}) ;{ }^{13} \mathrm{C}$ NMR $\left(150 \mathrm{MHz}, \mathrm{CDCl}_{3}\right) \delta 196.3,163.9,159.4,150.6,142.5,135.4,130.7,129.6$, $129.1,126.8,123.5,113.9,97.3,94.4,82.6,73.2,71.0,71.0,70.2,55.2,36.7,18.3,15.0$ CIHRMS Calcd for $\left[\mathrm{C}_{27} \mathrm{H}_{29} \mathrm{NO}_{10} \mathrm{Na}\right]^{+}: 550.1689$, Found 550.1690 . 
$(2 S, 3 S, 4 S, 6 S)-3-((2 S, \quad 5 R, \quad 6 R)-5,6-d i h y d r o-5-h y d r o x y-6-m e t h y l-2 H-p y r a n-2-y l o x y)-6-(4-$ methoxybenzyloxy)-tetrahydro-2-methyl-2H-pyran-4-yl 4-nitrobenzoate (ent-15): $:^{\dagger \dagger}$

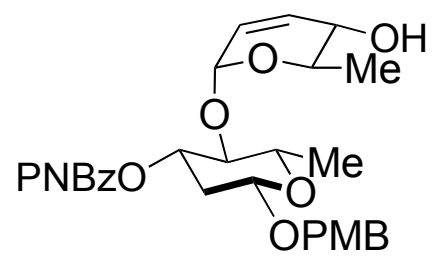

Pyranone ent-14 (2.0 g, $3.9 \mathrm{mmol})$ was dissolved in $10 \mathrm{~mL} \mathrm{CH}_{2} \mathrm{Cl}_{2}$, resulting solution was cooled to $-78^{\circ} \mathrm{C}, 10 \mathrm{~mL}$ of $0.4 \mathrm{M} \mathrm{CeCl}_{3}$ in methanol solution was added dropwise, followed by $200 \mathrm{mg}$ of $\mathrm{NaBH}_{4}$. By TLC tracking, the reaction was completed after $1.5 \mathrm{~h}$. The reaction mixture was diluted with $50 \mathrm{~mL}$ diethyl ether, and quenched with $2 \mathrm{~mL}$ water. Extraction by $3 \mathrm{x}$ $50 \mathrm{~mL}$ diethyl ether, drying over $\mathrm{Na}_{2} \mathrm{SO}_{4}$ and concentration under reduced pressure gave allylic alcohol ent-15 (2.0 g, $3.8 \mathrm{mmol}, 97 \%)$ as a white solid. $R_{f}(30 \% \mathrm{EtOAc} / \mathrm{hexanes})=0.20 ; \mathrm{mp}$ : 159.5-160.5 ${ }^{\circ} \mathrm{C} ;[\alpha]_{\mathrm{D}}^{21}=114\left(c=1.0, \mathrm{CH}_{2} \mathrm{Cl}_{2}\right) ; \mathrm{IR}$ (thin film, $\left.\mathrm{cm}^{-1}\right) 3384,1718,1527,1513$, 1282, 1104, 996, 717; ${ }^{1} \mathrm{H}$ NMR $\left(150 \mathrm{MHz}, \mathrm{CDCl}_{3}\right) \delta 8.26(\mathrm{~d}, J=11,1 \mathrm{H}), 8.19(\mathrm{~d}, J=11,1 \mathrm{H})$, $7.25(\mathrm{~d}, J=9.0,2 \mathrm{H}), 6.86(\mathrm{~d}, J=9.0,2 \mathrm{H}), 5.84(\mathrm{~d}, J=10.2,1 \mathrm{H}), 5.66(\mathrm{ddd}, J=10.2,2.4,2.4$, 1H), 5.21 (ddd, $J=12.0,8.4,5.41 \mathrm{H}), 5.04$ (d, $J=2.4,1 \mathrm{H}), 4.81(\mathrm{~d}, J=11.4,1 \mathrm{H}), 4.62(\mathrm{dd}, J=$ 9.6, 2.4 $1 \mathrm{H}), 4.53(\mathrm{~d}, J=11.4,1 \mathrm{H}), 3.79(\mathrm{~s}, 3 \mathrm{H}), 3.60(\mathrm{ddd}, J=9.0,9.0,1.8,1 \mathrm{H}), 3.53(\mathrm{dd}, J=$ $9.0,9.0,1 \mathrm{H}), 3.46(\mathrm{dq}, J=9.0,6.0,1 \mathrm{H}), 3.42(\mathrm{dq}, J=9.0,6.0,1 \mathrm{H}), 2.36(\mathrm{ddd}, J=12.6,5.4,1.8$, $1 \mathrm{H}), 1.80$ (ddd, $J=12.6,12,10.2,1 \mathrm{H}), 1.60(\mathrm{~s}, 1 \mathrm{H}), 1.41(\mathrm{~d}, J=6.6,1 \mathrm{H}), 0.81(\mathrm{~d}, J=6.0,1 \mathrm{H})$; ${ }^{13} \mathrm{C}$ NMR $\left(150 \mathrm{MHz}, \mathrm{CDCl}_{3}\right) \delta 164.0,159.4,150.5,135.8,133.2,130.8,129.7,129.2,126.2$, 123.5, 113.9, 97.4, 95.5, 81.8, 73.4, 71.3, 70.2, 69.1, 68.6, 55.3, 36.7, 18.4, 17.6; CIHRMS Calcd for $\left[\mathrm{C}_{27} \mathrm{H}_{31} \mathrm{NO}_{10} \mathrm{Na}\right]^{+}:$552.1846, Found 552.1841. 


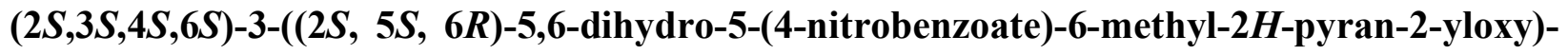
6-(4-methoxybenzyloxy)-tetrahydro-2-methyl-2H-pyran-4-yl 4-nitrobenzoate (ent-16): ${ }^{\dagger \dagger}$

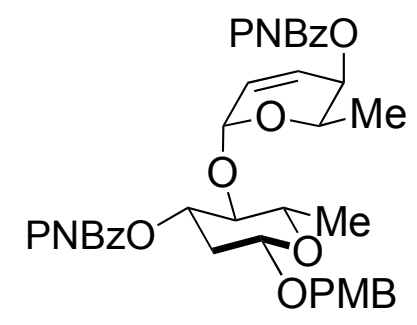

A THF $(0.7 \mathrm{~mL})$ solution of alcohol ent-15 $(1 \mathrm{~g}, 2.0 \mathrm{mmol})$ at $0{ }^{\circ} \mathrm{C}$ was added $\mathrm{PPh}_{3}(910 \mathrm{mg}, 4.0$ mmol) and p-nitrobenzoic acid (670 $\mathrm{mg}, 4.0 \mathrm{mmol})$. DIAD (8.0 g, $4.0 \mathrm{mmol})$ was added dropwise and the reaction mixture was warmed up to room temperature and stirred for three days. The reaction mixture was diluted with $5 \mathrm{~mL}$ EtOAc, quenched with $10 \mathrm{~mL}$ of satd. aq. $\mathrm{NaHCO}_{3}$, extracted (3 x $20 \mathrm{~mL}$ ) with methylene chloride, dried over $\mathrm{Na}_{2} \mathrm{SO}_{4}$, and concentrated under reduced pressure. The crude product was purified using silica gel flash chromatography eluting with $20 \%$ EtOAc/Hexanes to give ent-16 product (550 mg, $82 \mathrm{mmol}, 41 \%$ ) as a light yellow solid. $R_{f}(30 \%$ EtOAc/hexanes $)=0.40 ; \mathrm{mp}: 174-175^{\circ} \mathrm{C} ;[\alpha]_{\mathrm{D}}^{21}=-89.9\left(c=1.0, \mathrm{CH}_{2} \mathrm{Cl}_{2}\right)$; IR (thin film, $\left.\mathrm{cm}^{-1}\right)$ 2930, 1723, 1609, 1519, 1342, 1266, 1069, 1040, 987, 834, 754; ${ }^{1} \mathrm{H}$ NMR (600 $\left.\mathrm{MHz}, \mathrm{CDCl}_{3}\right) \delta 8.22(\mathrm{~d}, J=9.0,2 \mathrm{H}), 8.17(\mathrm{~d}, J=9.0,2 \mathrm{H}), 8.16(\mathrm{~d}, J=9.0,2 \mathrm{H}), 8.02(\mathrm{~d}, J=9.0$, 2H), $7.20(\mathrm{~d}, J=9.0,2 \mathrm{H}), 6.81(\mathrm{~d}, J=9.0,2 \mathrm{H}), 6.06(\mathrm{dd}, J=10.2,5.4,1 \mathrm{H}), 5.96(\mathrm{dd}, J=10.2$, 3.0, 1H), $5.21(\mathrm{ddd}, J=12.0,9.0,5.41 \mathrm{H}), 5.15(\mathrm{~d}, J=3,1 \mathrm{H}), 4.91(\mathrm{dd} \mathrm{J}=9.6,2.4,1 \mathrm{H}), 4.76(\mathrm{~d}$, $J=11.4,1 \mathrm{H}), 4.58(\mathrm{dd} \mathrm{J}=9.6,1.8,1 \mathrm{H}), 4.49(\mathrm{~d}, J=11.4,1 \mathrm{H}), 4.03(\mathrm{dq}, J=6.6,3,1 \mathrm{H}), 4.03$ $(\mathrm{dq}, J=9.0,6.2,1 \mathrm{H}), 3.74(\mathrm{~s}, 3 \mathrm{H}), 3.55(\mathrm{dd}, J=8.4,8.4,1 \mathrm{H}), 2.32(\mathrm{ddd}, J=12,6.0,1.8,1 \mathrm{H})$, $1.79(\mathrm{ddd}, J=15,9.6,9.6,1 \mathrm{H}), 1.38(\mathrm{~d}, J=6.6,3 \mathrm{H}), 0.71(\mathrm{~d}, J=6.6,3 \mathrm{H}) ;{ }^{13} \mathrm{C}(150 \mathrm{MHz}$, $\left.\mathrm{CDCl}_{3}\right) 164.1,164.0,159.5,150.7,150.6,135.7,135.0,130.9,130.7,130.6,129.7,129.2,125.1$, 
$123.5,123.5,113.9,97.3,95.3,81.8,73.2,71.3,70.2,66.1,65.3,55.3,36.7,18.5,15.8$; CIHRMS Calcd for $\left[\mathrm{C}_{34} \mathrm{H}_{34} \mathrm{~N}_{2} \mathrm{O}_{13} \mathrm{Na}\right]^{+}:$701.1959, Found 701.1961. 


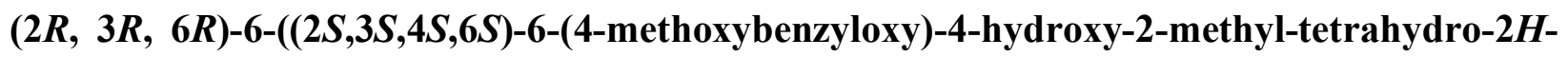
pyran-3-yloxy)-2-methyl-3,6-dihydro-2H-pyran-3-ol (ent-17): ${ }^{\dagger \dagger}$

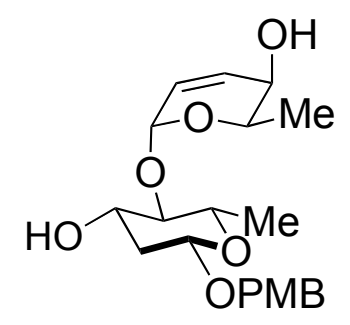

Bis-nitrobenzoate ent-16 (500 mg, $0.74 \mathrm{mmol}$ ) was dissolved in a mixed solvent of THF/ $\mathrm{H}_{2} \mathrm{O}$ $(15 \mathrm{~mL} / 3 \mathrm{~mL})$ at room temperature, $\mathrm{LiOH}(100 \mathrm{mg}, 4.20 \mathrm{mmol})$ was added and the reaction stirred for $24 \mathrm{~h}$. The reaction was quenched by adding $5 \mathrm{~mL}$ of satd. aq. $\mathrm{NaHCO}_{3}$, extracted $(3 \mathrm{x}$ $50 \mathrm{~mL}$ ) with methylene chloride, dried over $\mathrm{Na}_{2} \mathrm{SO}_{4}$, and concentrated under reduced pressure. The crude product was purified using silica gel flash chromatography eluting with $30 \%$ EtOAc/hexanes to give product ent-17 $(265 \mathrm{mg}, 0.70 \mathrm{mmol}, 70 \%)$ as a white solid. $R_{f}(50 \%$ EtOAc/hexanes $)=0.15 ; \mathrm{mp}: 118-119^{\circ} \mathrm{C} ;[\alpha]_{\mathrm{D}}^{21}=-15.0\left(c=1.0, \mathrm{CH}_{2} \mathrm{Cl}_{2}\right)$; IR (thin film, $\left.\mathrm{cm}^{-1}\right)$ 3420, 3390, 2922, 1611, 1513, 1456, 1360, 1246, 1094, 1000, 897, 823; ${ }^{1} \mathrm{H}$ NMR (600 MHz, $\left.\mathrm{CDCl}_{3}\right) \delta 7.27(\mathrm{~d}, J=8.4,2 \mathrm{H}), 6.87(\mathrm{~d}, J=8.4,2 \mathrm{H}), 6.22(\mathrm{dd}, J=10.2,5.4,1.2,1 \mathrm{H}), 5.87(\mathrm{dd}, J$ $=10.2,3.6,1 \mathrm{H}), 5.07(\mathrm{dd}, J=2.4,0.6,1 \mathrm{H}), 4.82(\mathrm{~d}, J=12.0,1 \mathrm{H}), 4.60(\mathrm{~m}, 1 \mathrm{H}), 4.53(\mathrm{~d}, J=$ 12.0, 1H), $4.52(\mathrm{dd}, J=9.6,2.4,1 \mathrm{H}), 4.22(\mathrm{qd}, J=6.6,2.4,1 \mathrm{H}), 3.80(\mathrm{~s}, 3 \mathrm{H}), 3.63(\mathrm{~m}, 1 \mathrm{H}), 3.60$ (ddd, $J=12.0,8.4,5.4,1 \mathrm{H}), 3.32(\mathrm{dq}, J=9,6.0,1 \mathrm{H}), 3.04(\mathrm{dd}, J=8.4,8.4,1 \mathrm{H}), 2.25$ (ddd, $J=$ 12.6, 5.4, 1.8, 1H), $1.67(\mathrm{ddd}, J=12.6,12.0,9.6,1 \mathrm{H}), 1.51(\mathrm{~m}, 1 \mathrm{H}), 1.35(\mathrm{~d}, J=6.6,3 \mathrm{H}), 1.33$ $(\mathrm{d}, J=6.6,3 \mathrm{H}) ;{ }^{13} \mathrm{C}$ NMR $\left(150 \mathrm{MHz}, \mathrm{CDCl}_{3}\right) 159.3,130.3,129.6,129.5,127.2,113.8,98.1$, 96.6, 88.9, 70.4, 70.1, 70.0, 67.8, 63.5, 55.3, 38.2, 18.0, 15.9; CIHRMS Calcd for $\left[\mathrm{C}_{20} \mathrm{H}_{28} \mathrm{O}_{7} \mathrm{Na}\right]^{+}$: 403.1733, Found 403.1728. 


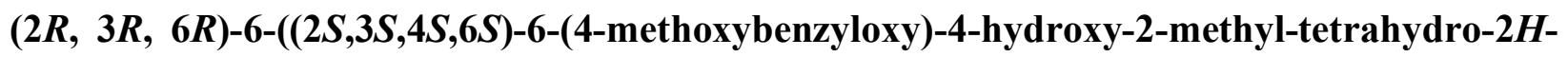
pyran-3-yloxy)-2-methyl-tetrahydro-2H-pyran-3-ol (ent-18): ${ }^{\dagger \dagger}$

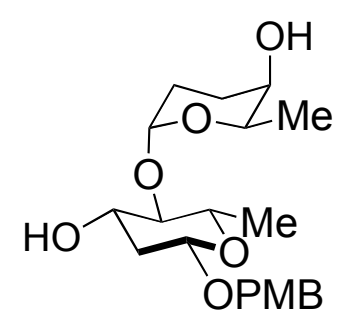

Allylic alcohol ent-17 (250 mg, $66 \mathrm{mmol})$ was dissolved in $\mathrm{CH}_{2} \mathrm{Cl}_{2}(11 \mathrm{~mL})$ at room temperature. NBSH $(1.33 \mathrm{~g}, 6.55 \mathrm{mmol})$ and $\mathrm{Et}_{3} \mathrm{~N}(0.88 \mathrm{~g}, 8.74 \mathrm{mmol})$ were added while stirring. The reaction was tracked by TLC. The reaction was quenched by adding $10 \mathrm{~mL}$ of satd. aq. $\mathrm{NaHCO}_{3}$ after 12 hours, extracted $(3 \times 50 \mathrm{~mL})$ with methylene chloride, dried over $\mathrm{Na}_{2} \mathrm{SO}_{4}$, and concentrated under reduced pressure. The crude product was purified using silica gel flash chromatography eluting with 30\% EtOAc/hexanes to give diol ent-18 (250 mg, $66 \mathrm{mmol}, 99 \%$ ) as a yellow oil. $R_{f}(50 \%$ EtOAc/hexanes $)=0.15 ;[\alpha]_{\mathrm{D}}^{21}=95\left(c=1.0, \mathrm{CH}_{2} \mathrm{Cl}_{2}\right)$; IR (thin film, $\left.\mathrm{cm}^{-1}\right)$ $3390,2933,1612,1514,1443,1368,1246,1166,1114,1066,1011,940,818 ;{ }^{1} \mathrm{H}$ NMR $(600$ $\left.\mathrm{MHz}, \mathrm{CDCl}_{3}\right) \delta 7.27(\mathrm{~d}, J=9.0,2 \mathrm{H}), 6.87(\mathrm{~d}, J=9.0,2 \mathrm{H}), 4.92(\mathrm{~d}, J=3,1 \mathrm{H}), 4.91(\mathrm{~d}, J=3$, 1H), $4.81(\mathrm{~d}, J=11.4,1 \mathrm{H}), 4.79(\mathrm{~d}, J=1.2,1 \mathrm{H}), 4.52$ (d, $J=11.4,1 \mathrm{H}), 4.50(\mathrm{dd}, J=10.2,2.4$, $1 \mathrm{H}), 3.79(\mathrm{~s}, 3 \mathrm{H}), 4.14(\mathrm{qd}, J=6.6,1.2,1 \mathrm{H}), 3.62(\mathrm{~m}, 1 \mathrm{H}), 3.56(\mathrm{~m}, 1 \mathrm{H}), 3.31(\mathrm{dq}, J=9,6.0$, 1H), 2.98 (dd, $J=8.4,8.4,1 \mathrm{H}), 2.21$ (ddd, $J=12.6,5.4,1.8,1 \mathrm{H}), 2.06$ (ddd, $J=13.8,13.8,3.6$, 3.6, 1H), 1.98 (ddd, $J=13.8,13.8,3,3,1 \mathrm{H}), 1.76(\mathrm{ddd}, J=13.2,7.2,3.6,1 \mathrm{H}), 1.68-1.58(\mathrm{~m}$, $2 \mathrm{H}), 1.32(\mathrm{~d}, J=6.6,3 \mathrm{H}), 1.21(\mathrm{~d}, J=6.6,3 \mathrm{H}) ;{ }^{13} \mathrm{C} \mathrm{NMR}\left(150 \mathrm{MHz}, \mathrm{CDCl}_{3}\right)$ 159.3, 129.7, $129.5,113.8,99.6,98.0,88.7,70.4,70.3,69.9,68.0,67.1,55.3,38.2,25.4,24.2,18.1,16.9$; CIHRMS Calcd for $\left[\mathrm{C}_{20} \mathrm{H}_{30} \mathrm{O}_{7} \mathrm{Na}\right]^{+}: 405.1889$, Found 405.1885. 


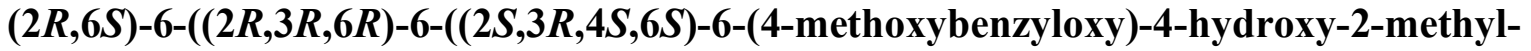

tetrahydro-2H-pyran-3-yloxy)-2-methyl-tetrahydro-2H-pyran-3-yloxy)-2-methyl-2H3(6H)-pyran-3-one (ent-19): ${ }^{\dagger \dagger}$

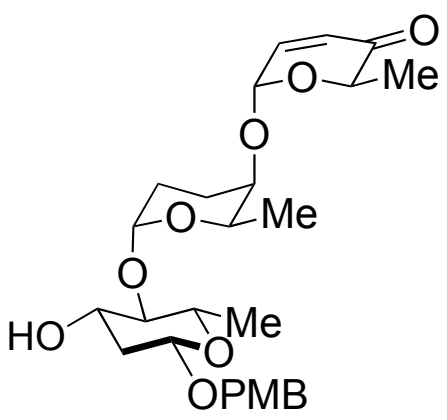

$\mathrm{A} \mathrm{CH}_{2} \mathrm{Cl}_{2}(0.1 \mathrm{~mL})$ solution of Boc pyranone $5(\alpha-\mathrm{L})(65 \mathrm{mg}, 29 \mathrm{mmol})$ and alcohol $(50 \mathrm{mg}, 0.13$ mmol) was cooled to $0{ }^{\circ} \mathrm{C} . \mathrm{Pd}_{2}(\mathrm{DBA})_{3}{ }^{\circ} \mathrm{CHCl}_{3}(1.22 \mathrm{mg}, 1.3 \mathrm{~mol} \%)$ and $\mathrm{PPh}_{3}(1.06 \mathrm{mg}, 5 \mathrm{~mol} \%)$ were added to the reaction mixture at $0{ }^{\circ} \mathrm{C}$. After stirring at room temperature for $12 \mathrm{~h}$, the reaction mixture was quenched with $1 \mathrm{~mL}$ of satd. aq. $\mathrm{NaHCO}_{3}$, extracted $(3 \times 5 \mathrm{~mL})$ with $\mathrm{CH}_{2} \mathrm{Cl}_{2}$, dried over $\mathrm{Na}_{2} \mathrm{SO}_{4}$ and concentrated under reduced pressure. The crude product was purified using silica gel flash chromatography eluting with $20 \%$ EtOAc/Hexanes to give pyranone ent-19 (25 mg, $0.05 \mathrm{mmol}, 40 \%)$ as a white solid along with 50\% recovered starting material ent-18 (25 mg, $0.065 \mathrm{mmol}): R_{f}(50 \%$ EtOAc/hexane $)=0.50 ; \mathrm{mp}: 112-113{ }^{\circ} \mathrm{C} ;[\alpha]_{\mathrm{D}}^{21}=$ $18\left(c=1.0, \mathrm{CH}_{2} \mathrm{Cl}_{2}\right)$; IR (thin film, $\left.\mathrm{cm}^{-1}\right) 3417,2920,1698,1612,1514,1457,1371,1247,1067$, 1030, 810; ${ }^{1} \mathrm{H}$ NMR $\left(600 \mathrm{MHz}, \mathrm{CDCl}_{3}\right) \delta 7.21(\mathrm{~d}, J=9.0,2 \mathrm{H}), 6.82(\mathrm{~d}, J=9.0,2 \mathrm{H}), 6.79(\mathrm{dd}, J$ $=10.2,3.6,1 \mathrm{H}), 6.03(\mathrm{~d}, J=10.2,1 \mathrm{H}), 5.16(\mathrm{~d}, J=3.6,1 \mathrm{H}), 4.87(\mathrm{~m}, 1 \mathrm{H}), 4.75(\mathrm{~d}, J=11.4,1 \mathrm{H})$, $4.48(\mathrm{q}, J=6.6,1 \mathrm{H}), 4.46(\mathrm{~d}, J=11.4,1 \mathrm{H}), 3.73(\mathrm{~s}, 3 \mathrm{H}), 4.68(\mathrm{~m}, 1 \mathrm{H}), 4.45(\mathrm{dd}, J=10,5,1 \mathrm{H})$, $4.09(\mathrm{qd}, J=6.6,1.2,1 \mathrm{H}), 3.60(\mathrm{~m}, 1 \mathrm{H}), 3.50(\mathrm{~m}, 1 \mathrm{H}), 3.25(\mathrm{dq}, J=9,6.0,1 \mathrm{H}), 2.91(\mathrm{dd}, \mathrm{J}=9$, 9, $1 \mathrm{H}), 2.15(\mathrm{ddd}, J=12.6,5.4,1.8,1 \mathrm{H}), 2.02-1.95(\mathrm{~m}, 2 \mathrm{H}), 1.90-1.85(\mathrm{~m}, 1 \mathrm{H}), 1.60-1.54(\mathrm{~m}$, 
$2 \mathrm{H}), 1.35(\mathrm{~d}, J=6.6,3 \mathrm{H}), 1.30(\mathrm{~d}, J=6.6,3 \mathrm{H}), 1.16(\mathrm{~d}, J=6.6,3 \mathrm{H}) ;{ }^{13} \mathrm{C}$ NMR $(150 \mathrm{MHz}$, $\left.\mathrm{CDCl}_{3}\right) 196.5,159.3,142.7,129.6,129.5,127.4,113.8,98.3,98.0,95.2,88.6,76.1,70.6,70.4$ $70.3,69.9,67.7,55.2,38.2,25.1,24.3,18.1,16.9,15.1$; CIHRMS Calcd for $\left[\mathrm{C}_{26} \mathrm{H}_{36} \mathrm{O}_{9} \mathrm{Na}\right]^{+}$: 515.2257, Found 515.2253.

(2S,6R)-6-((2S,3S,6S)-6-((2R,3S,4R,6R)-6-(4-methoxybenzyloxy)-4-acetoxy-2methyl-tetrahydro-2H-pyran-3-yloxy)-2-methyl-tetrahydro-2H-pyran-3-yloxy)2-methyl-2H-3(6H)-one (20):

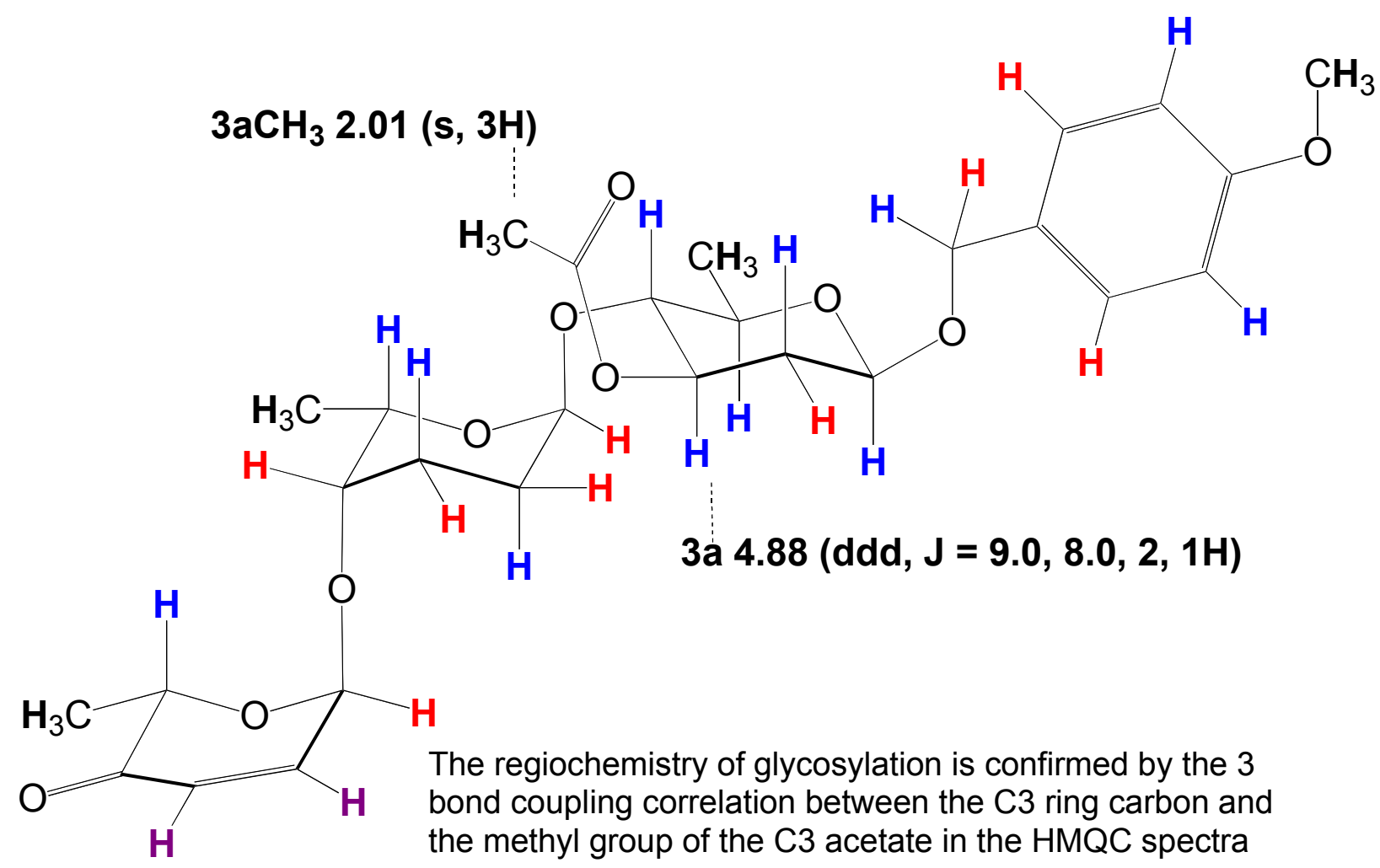




\section{C: Experimental Procedures for Chapter II:}

(6R)-6-pivaloyl-(2R)-2-methyl 2H-pyran-3(6H)-one (35).

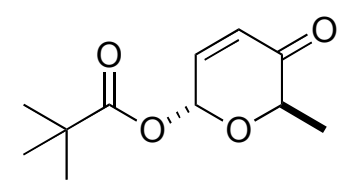

Compound 7a $(2.22 \mathrm{~g}, 8.59 \mathrm{mmol}), 30 \mathrm{~mL}$ of $\mathrm{CH}_{2} \mathrm{Cl}_{2}$, and $1.5 \mathrm{~mL}$ of $\mathrm{Et}_{3} \mathrm{~N}$ were added to a round bottom flask and cooled to $-78{ }^{\circ} \mathrm{C}$. A catalytic amount $(53 \mathrm{mg}, 0.43 \mathrm{mmol})$ of DMAP and pivaloyl chloride $(1.06 \mathrm{~mL}, 8.59 \mathrm{mmol})$ were added and the solution was stirred for $3 \mathrm{~h}$ at $-78^{\circ} \mathrm{C}$. The reaction was quenched with $50 \mathrm{~mL}$ of sat. aq. $\mathrm{NaHCO}_{3}$, extracted $(3 \times 50 \mathrm{~mL})$ with $\mathrm{Et}_{2} \mathrm{O}$, dried $\left(\mathrm{Na}_{2} \mathrm{SO}_{4}\right)$, and concentrated under reduced pressure. The crude product was purified using silica gel flash chromatography eluting with $10 \%$ EtOAc/hexanes to give $2.41 \mathrm{~g}$ (7.04 mmol, 82 $\%)$ of 35. $\mathrm{R}_{f}(20 \%$ EtOAc/hexanes $)=0.4 ;[\alpha]^{21}{ }_{\mathrm{D}}=-66\left(\mathrm{c}=0.1, \mathrm{CH}_{2} \mathrm{Cl}_{2}\right)$; IR (thin film, $\left.\mathrm{cm}^{-1}\right)$ 2935, 2910, 2855, 1738, 1692, 1461, 1399, 1279; ${ }^{1} \mathrm{H}$ NMR $\left(600 \mathrm{MHz}, \mathrm{CDCl}_{3}\right) \delta 6.88(\mathrm{dd}, J=$ 10.2, 3.6 Hz, 1H), $6.46(\mathrm{~d}, J=3.6 \mathrm{~Hz}, 1 \mathrm{H}), 6.19(\mathrm{~d}, J=10.2 \mathrm{~Hz}, 1 \mathrm{H}), 4.57(\mathrm{q}, J=6.6 \mathrm{~Hz}, 1 \mathrm{H})$, $1.40(\mathrm{~d}, J=6.6 \mathrm{~Hz}, 3 \mathrm{H}), 1.23(\mathrm{~s}, 9 \mathrm{H}),{ }^{13} \mathrm{C} \mathrm{NMR}\left(150 \mathrm{MHz}, \mathrm{CDCl}_{3}\right) \delta 195.9,177.0,141.8,128.2$, 86.9, 72.3, 39.2, 27.0, 15.4; CI HRMS calcd for $\left[\mathrm{C}_{11} \mathrm{H}_{16} \mathrm{O}_{4}\right]^{+}: 212.1049$, Found 212.1045. 
$((2 R, 5 S, 6 R)-5,6-d i h y d r o-5-h y d r o x y-6-m e t h y l-2 H-p y r a n-2-y l$ pivalate (36).

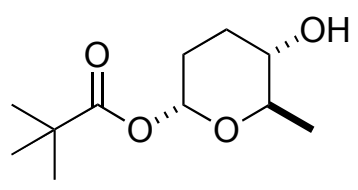

A solution of pyranone $35(580 \mathrm{mg}, 2.74 \mathrm{mmol})$ in $\mathrm{CH}_{2} \mathrm{Cl}_{2}(1.5 \mathrm{~mL})$ and $0.4 \mathrm{M} \mathrm{CeCl} / \mathrm{MeOH}$ (1.5 mL) was cooled to $-78{ }^{\circ} \mathrm{C}$. $\mathrm{NaBH}_{4}(58.4 \mathrm{mg}, 1.54 \mathrm{mmol})$ was added and the reaction mixture was stirred for $4 \mathrm{~h}$ at $-78{ }^{\circ} \mathrm{C}$. The resulting solution was diluted with ether $(10 \mathrm{~mL})$, quenched with $5 \mathrm{~mL}$ of saturated $\mathrm{NaHCO}_{3}$, extracted $(3 \times 5 \mathrm{~mL})$ with $\mathrm{Et}_{2} \mathrm{O}$, dried $\left(\mathrm{Na}_{2} \mathrm{SO}_{4}\right)$, and concentrated under reduced pressure. The crude product was purified using silica gel chromatography eluting with 40\% EtOAc/hexane to give enol 36 (400 mg, $1.90 \mathrm{mmol}, 68 \%$ ) as a white solid, mp: $62.5-64.0{ }^{\circ} \mathrm{C} ; R f=0.30\left(40 \%\right.$ EtOAc/Hexane); $[\alpha]_{\mathrm{D}}^{21}=21\left(c=0.55, \mathrm{CH}_{2} \mathrm{Cl}_{2}\right)$; IR (thin film, $\mathrm{cm}^{-1}$ ) 3391, 2972, 2933, 2837, 1720, 1612, 1513, 1246, 1029, 999, 819; ${ }^{1} \mathrm{H}$ NMR $\left(600 \mathrm{MHz}, \mathrm{CDCl}_{3}\right) \delta 6.21(\mathrm{dd}, J=2.4,1.8 \mathrm{~Hz}, 1 \mathrm{H}), 6.04(\mathrm{~d}, J=9.6 \mathrm{~Hz}, 1 \mathrm{H}), 5.75(\mathrm{ddd}, J=10.2$, 2.4, $2.4 \mathrm{~Hz}, 1 \mathrm{H}), 3.90(\mathrm{~d}, J=8.4 \mathrm{~Hz}, 1 \mathrm{H}), 3.72(\mathrm{~m}, 1 \mathrm{H}), 2.20(\mathrm{~s}, 1 \mathrm{H}), 1.31(\mathrm{~d}, J=6.6 \mathrm{~Hz}, 3 \mathrm{H})$, $1.20(\mathrm{~s}, 9 \mathrm{H}) ;{ }^{13} \mathrm{C} \mathrm{NMR}\left(150 \mathrm{MHz}, \mathrm{CDCl}_{3}\right) \delta 177.7,134.7,125.1,88.4,70.3,69.2,39.1,27.1$, 18.0; CIHRMS: Calculated for $\left[\mathrm{C}_{11} \mathrm{H}_{18} \mathrm{O}_{4} \mathrm{Na}^{+}\right]$: 237.1102. Found: 237.1099. 
$((2 R, 5 S, 6 R)-3,4,5,6-t e t r a h y d r o-5-h y d r o x y-6-m e t h y l-2 H-p y r a n-2-y l$ pivalate (37).

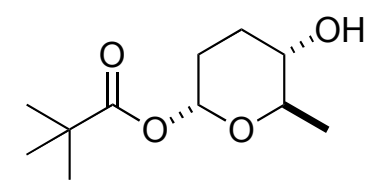

A solution of allylic alcohol $36(370 \mathrm{mg}, 1.73 \mathrm{mmol})$ was dissolved in $\mathrm{CH}_{2} \mathrm{Cl}_{2}(11 \mathrm{~mL})$ at room temperature. NBSH $(1.33 \mathrm{~g}, 6.55 \mathrm{mmol})$ and $\mathrm{Et}_{3} \mathrm{~N}(0.88 \mathrm{~g}, 8.74 \mathrm{mmol})$ were added while stirring. The reaction was tracked by TLC. After $12 \mathrm{~h}$, the reaction was quenched by adding $10 \mathrm{~mL}$ of satd. aq. $\mathrm{NaHCO}_{3}$, extracted $(3 \times 50 \mathrm{~mL})$ with methylene chloride, dried over $\mathrm{Na}_{2} \mathrm{SO}_{4}$, and concentrated under reduced pressure. The crude product was purified using silica gel flash chromatography eluting with 30\% EtOAc/hexanes to give 37 (420 mg, $1.09 \mathrm{mmol}, 80 \%)$ as a yellow oil. $R_{f}(50 \%$ EtOAc/hexanes $)=0.15 ;[\alpha]_{\mathrm{D}}^{21}=-105\left(c=1.0, \mathrm{CH}_{2} \mathrm{Cl}_{2}\right) ; \mathrm{IR}$ (thin film, $\left.\mathrm{cm}^{-1}\right)$ $3390,2933,1724,1443,1368,1246,1166,1114,1066,1011,940,818 ;{ }^{1} \mathrm{H}$ NMR; ${ }^{1} \mathrm{H}$ NMR $(600$ $\left.\mathrm{MHz}, \mathrm{CDCl}_{3}\right) \delta 6.01(\mathrm{~s}, 1 \mathrm{H}), 6.04(\mathrm{~d}, J=9.6 \mathrm{~Hz}, 1 \mathrm{H}), 3.65(\mathrm{dq}, J=9,6.6,1 \mathrm{H}), 3.30(\mathrm{ddd}, J=$ $10.2,5.4,1.8,1 \mathrm{H}), 1.98-1.65(\mathrm{~m}, 4 \mathrm{H}), 1.23(\mathrm{~d}, J=6.6 \mathrm{~Hz}, 3 \mathrm{H}), 1.20(\mathrm{~s}, 9 \mathrm{H}) ;{ }^{13} \mathrm{C} \mathrm{NMR}(150$ $\left.\mathrm{MHz}, \mathrm{CDCl}_{3}\right) \delta 177.0,90.7,71.8,71.5,39.1,28.5,27.2,27.0,17.9$; CIHRMS: Calculated for $\left[\mathrm{C}_{11} \mathrm{H}_{20} \mathrm{O}_{4} \mathrm{Na}^{+}\right]$: 239.1259. Found: 239.1264 


\section{5-hydroxy-6-methyl-2H-pyran-2-yl pivalate (38).}

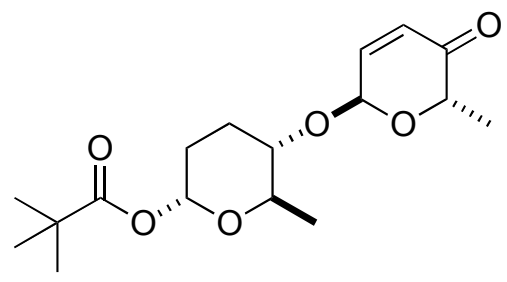

$\mathrm{A} \mathrm{CH}_{2} \mathrm{Cl}_{2}(1.0 \mathrm{~mL})$ solution of Boc pyranone $\mathbf{5}(\boldsymbol{\alpha}-\mathbf{L})(422 \mathrm{mg}, 1.85 \mathrm{mmol})$ and alcohol 37 (200 mg, $0.93 \mathrm{mmol})$ was cooled to $0{ }^{\circ} \mathrm{C} . \mathrm{Pd}_{2}(\mathrm{DBA})_{3} \cdot \mathrm{CHCl}_{3}(24 \mathrm{mg}, 2.5 \mathrm{~mol} \%)$ and $\mathrm{PPh}_{3}(21 \mathrm{mg}, 10$ mol\%) were added to the reaction mixture at $0{ }^{\circ} \mathrm{C}$. After stirring at room temperature for $8 \mathrm{~h}$, the reaction mixture was quenched with $10 \mathrm{~mL}$ of satd. aq. $\mathrm{NaHCO}_{3}$, extracted $(3 \times 10 \mathrm{~mL})$ with $\mathrm{Et}_{2} \mathrm{O}$, dried over $\mathrm{Na}_{2} \mathrm{SO}_{4}$ and concentrated under reduced pressure. The crude product was purified using silica gel flash chromatography eluting with 20\% EtOAc/hexanes to give pyranone $38(210 \mathrm{mg}, 0.65 \mathrm{mmol}, 70 \%)$ as a yellow oil: $R_{f}(30 \%$ EtOAc/hexanes $)=0.5 ;[\alpha]_{\mathrm{D}}^{21}=$ $-105\left(c=1.0, \mathrm{CH}_{2} \mathrm{Cl}_{2}\right)$; IR (thin film, $\left.\mathrm{cm}^{-1}\right) 2933,1731,1701,1443,1368,1246,1166,1114$, 1066, 1011, 940, 818; ${ }^{1} \mathrm{H}$ NMR; ${ }^{1} \mathrm{H}$ NMR (600 MHz, $\left.\mathrm{CDCl}_{3}\right) \delta 6.75$ (dd, $\left.J=10.2,3.6,1 \mathrm{H}\right), 6.04$ $(\mathrm{d}, J=10.2,1 \mathrm{H}), 5.98(\mathrm{~s}, 1 \mathrm{H}), 5.25(\mathrm{~d}, J=9.6 \mathrm{~Hz}, 1 \mathrm{H}), 4.55(\mathrm{q}, J=6.6,1 \mathrm{H}), 3.73(\mathrm{dq}, J=9,6.6$ $1 \mathrm{H}), 3.30(\mathrm{~m}, 1 \mathrm{H}), 2.09-2.01(\mathrm{~m}, 2 \mathrm{H}), 1.89-1.79(\mathrm{~m}, 2 \mathrm{H}), 1.33(\mathrm{~d}, J=6.6 \mathrm{~Hz}, 3 \mathrm{H}), 1.19(\mathrm{~d}, J=$ $6.6 \mathrm{~Hz}, 3 \mathrm{H}), 1.20(\mathrm{~s}, 9 \mathrm{H}) ;{ }^{13} \mathrm{C} \mathrm{NMR}\left(150 \mathrm{MHz}, \mathrm{CDCl}_{3}\right) \delta 196.4,176.6,142.7,127.2,94.7,90.4$, $80.2, \quad 70.2, \quad 69.8, \quad 38.9, \quad 28.2, \quad 26.9, \quad 25.8, \quad 17.9, \quad 15.0 ; \quad$ CIHRMS: Calculated for $\left[\mathrm{C}_{17} \mathrm{H}_{26} \mathrm{NaO}_{6}^{+}\right]: 349.3745$. Found: 349.3750 . 


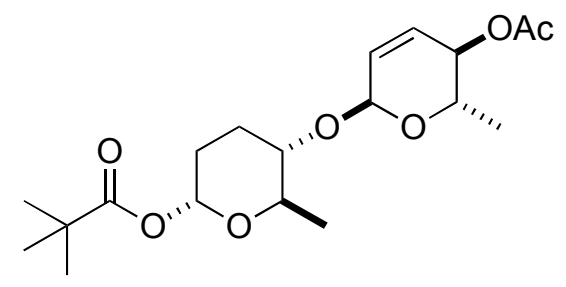

A solution of pyranone $38(50 \mathrm{mg}, 2.74 \mathrm{mmol})$ in $\mathrm{CH}_{2} \mathrm{Cl}_{2}(1.5 \mathrm{~mL})$ and $0.4 \mathrm{M} \mathrm{CeCl}_{3} / \mathrm{MeOH}(1.5$ $\mathrm{mL})$ was cooled to $-78{ }^{\circ} \mathrm{C} . \mathrm{NaBH}_{4}(58.4 \mathrm{mg}, 1.54 \mathrm{mmol})$ was added and the reaction mixture was stirred for $4 \mathrm{~h}$ at $-78^{\circ} \mathrm{C}$. The resulting solution was diluted with ether $(10 \mathrm{~mL})$, quenched with $5 \mathrm{~mL}$ of saturated $\mathrm{NaHCO}_{3}$, extracted $(3 \times 5 \mathrm{~mL})$ with $\mathrm{Et}_{2} \mathrm{O}$, dried $\left(\mathrm{Na}_{2} \mathrm{SO}_{4}\right)$, and concentrated under reduced pressure. The crude product was dissolved in $\mathrm{CH}_{2} \mathrm{Cl}_{2}(1.5 \mathrm{~mL})$ and DMAP $(10 \mathrm{mg})$ and acetic anhydride $(2 \mathrm{~mL})$ was added. After $10 \mathrm{~min}$ the reaction was quenched by adding of $\mathrm{Et}_{2} \mathrm{O}(5 \mathrm{~mL})$ and $10 \mathrm{~mL}$ of satd. aq. $\mathrm{NaHCO}_{3}$. Resulting mixture was extracted $(3 \times 10 \mathrm{~mL})$ with $\mathrm{Et}_{2} \mathrm{O}$, dried over $\mathrm{Na}_{2} \mathrm{SO}_{4}$ and concentrated under reduced pressure. The crude product was purified using silica gel flash chromatography eluting with $20 \%$ EtOAc/hexanes to give allylic acetate $39(65 \mathrm{mg}, 0.65 \mathrm{mmol}, 70 \%)$ as a yellow oil: $R_{f}(30 \%$ EtOAc/hexanes $)=0.5 ;[\alpha]_{\mathrm{D}}^{21}=-65\left(c=1.0, \mathrm{CH}_{2} \mathrm{Cl}_{2}\right) ; \mathrm{IR}\left(\right.$ thin film, $\left.\mathrm{cm}^{-1}\right) 2933,1731,1725$, 1443, 1368, 1246, 1166, 1114, 1066, 1011, 940, 818; ${ }^{1} \mathrm{H}$ NMR; ${ }^{1} \mathrm{H}$ NMR $\left(600 \mathrm{MHz}, \mathrm{CDCl}_{3}\right) \delta$ $6.02(\mathrm{~s}, 1 \mathrm{H}), 5.85(\mathrm{~d}, J=10.2,1 \mathrm{H}), 5.77(\mathrm{ddd}, J=10.2,2.4,2.41 \mathrm{H}), 5.05(\mathrm{~m}, 1 \mathrm{H}), 5.03(\mathrm{~m}, 1 \mathrm{H})$ $3.99(\mathrm{dq}, J=9.6,6.6,1 \mathrm{H}), 3.76(\mathrm{dq}, J=9.6,6.6,1 \mathrm{H}), 3.30(\mathrm{~m}, 1 \mathrm{H}), 2.06(\mathrm{~s}, 3 \mathrm{H}), 1.89-1.79(\mathrm{~m}$, 2H), $1.20(\mathrm{~d}, J=6.6 \mathrm{~Hz}, 3 \mathrm{H}),, 1.21(\mathrm{~s}, 9 \mathrm{H}) 1.19(\mathrm{~d}, J=6.6 \mathrm{~Hz}, 3 \mathrm{H}) ;{ }^{13} \mathrm{C}$ NMR $(150 \mathrm{MHz}$, 
$\left.\mathrm{CDCl}_{3}\right) \delta 177.1,170.7,130.2,127.6,96.3,91.0,80.1,71.0,70.5,65.0,39.3,28.7,27.3,26.6$,

21.2, 18.3, 18.1; CIHRMS: Calculated for $\left[\mathrm{C}_{19} \mathrm{H}_{30} \mathrm{NaO}_{7}^{+}\right]$:393.4271. Found: 393.4269. 


\section{2-Bromo-8-hydroxy-1,4-dimethoxynaphthalene 33}

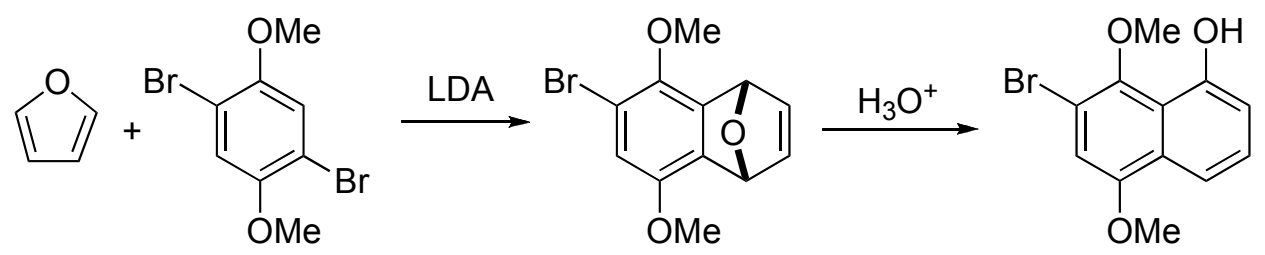

To a solution of LDA in THF at $-78{ }^{\circ} \mathrm{C}$ was added furan (), and 2,5-dibromo-1,4dimethoxybenzene $\mathbf{3 1}$ was slowly added. The solution was stirred at $-78{ }^{\circ} \mathrm{C}$ for $30 \mathrm{~min}$, quenched by the addition of $10 \mathrm{~mL}$ of satd. aq. $\mathrm{NaHCO}_{3}$, extracted $(3 \times 10 \mathrm{~mL})$ with $\mathrm{Et}_{2} \mathrm{O}$, dried over $\mathrm{Na}_{2} \mathrm{SO}_{4}$ and concentrated under reduced pressure.

${ }^{1} \mathrm{H}$ NMR $\left(600 \mathrm{MHz}, \mathrm{CDCl}_{3}\right) \delta 7.06(\mathrm{dd}, J=6,1.8 \mathrm{~Hz}, 1 \mathrm{H}), 7.01(\mathrm{dd}, J=6,1.8 \mathrm{~Hz}, 1 \mathrm{H}), 6.78(\mathrm{~s}$, 1H), $5.97(\mathrm{dd}, J=6,1.8 \mathrm{~Hz}, 1 \mathrm{H}), 5.87(\mathrm{dd}, J=1,1 \mathrm{~Hz}, 1 \mathrm{H}), 3.84(\mathrm{~S}, 3 \mathrm{H}), 3.76(\mathrm{~s}, 3 \mathrm{H})$.

The crude cyclo-adduct 32 was dissolved in $\mathrm{MeOH} / \mathrm{H}_{2} \mathrm{O}$ at RT and then $\mathrm{HCl}(6 \mathrm{M})$ was added. After the reaction was refluxed for $8 \mathrm{hr}$, it was cooled to room temperature. The reaction was quenched with $10 \mathrm{~mL}$ of satd. aq. $\mathrm{NaHCO}_{3}$, extracted $(3 \times 10 \mathrm{~mL})$ with $\mathrm{Et}_{2} \mathrm{O}$, dried over $\mathrm{Na}_{2} \mathrm{SO}_{4}$ and concentrated under reduced pressure. The crude product was purified by flash chromatography using hexane-ethyl acetate (4:1) as eluent to afford $\mathbf{1 2}(356 \mathrm{mg}, 94 \%)$ as a tan solid.

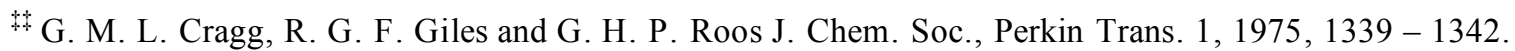


${ }^{1} \mathrm{H}$ NMR $\left(600 \mathrm{MHz}, \mathrm{CDCl}_{3}\right) \delta 9.37(\mathrm{~S}, 1 \mathrm{H}), 7.68(\mathrm{dd}, J=8.4,0.6 \mathrm{~Hz}, 1 \mathrm{H}), 7.40(\mathrm{dd}, J=8.1,8.1$ $\mathrm{Hz}, 1 \mathrm{H}), 6.94(\mathrm{dd}, J=7.8,0.6 \mathrm{~Hz}, 1 \mathrm{H}), 6.82(\mathrm{~s}, 1 \mathrm{H}), 4.00(\mathrm{~s}, 3 \mathrm{H}), 3.94(\mathrm{~s}, 3 \mathrm{H}) ;{ }^{13} \mathrm{C}$ NMR $(150$ $\left.\mathrm{MHz}, \mathrm{CDCl}_{3}\right) \delta 153.2,153.0,146.3,127.7,127.7,118.3,113.9,112.6,110.7,108.4,62.8,56.2$. 
$(2 R, 3 S, 4 R, 6 R)-6-(7-b r o m o-5,8-d i m e t h o x y n a p h t h a l e n y l o x y)-2-m e t h y l-3-((2 S, 5 S, 6 S)-6-$

methyl-5-((2R,6S)-6-methyl-5-oxo-5,6-dihydro-2H-pyran-2-yloxy)-tetrahydro-2H-pyran-2yloxy)-tetrahydro-2 $H$-pyran-4-yl acetate (44 ):

$(2 R, 3 S, 4 R, 6 S)-6-(7-b r o m o-5,8-d i m e t h o x y n a p h t h a l e n y l o x y)-2-m e t h y l-3-((2 S, 5 S, 6 S)-6-$ methyl-5-((2R,6S)-6-methyl-5-ox0-5,6-dihydro-2H-pyran-2-yloxy)-tetrahydro-2H-pyran-2yloxy)-tetrahydro-2H-pyran-4-yl acetate (44ß):

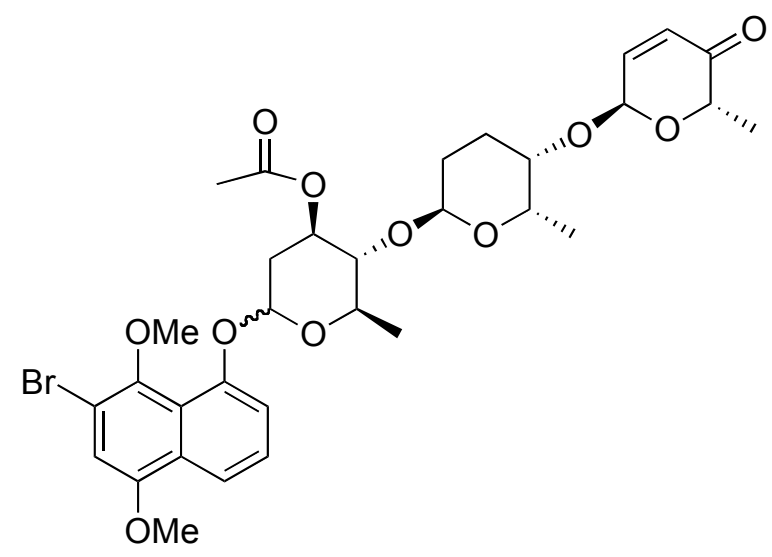

To a THF (0.5 mL) solution of alcohol $43(50 \mathrm{mg}, 0.121 \mathrm{mmol})$, phenol 33 (68 mg, $0.242 \mathrm{mmol})$ and $\mathrm{PPh}_{3}(54.7 \mathrm{mg}, 0.242 \mathrm{mmol})$ was added DIAD $(48 \mu \mathrm{L})$ at room temperature. The reaction mixture was stirred at room temperature for $48 \mathrm{~h}$. Reaction mixture was washed with $2 \mathrm{~mL}$ of satd. aq. $\mathrm{NaHCO}_{3}$, extracted with $\mathrm{CH}_{2} \mathrm{Cl}_{2}(3 \times 5 \mathrm{~mL})$, dried over $\mathrm{Na}_{2} \mathrm{SO}_{4}$ and concentrated under reduced pressure. The crude product was purified using silica gel flash chromatography eluting with $20 \%$ EtOAc/hexanes to give $\mathbf{4 0}(67 \mathrm{mg}, 0.13 \mathrm{mmol}, 82 \%)$ as a mixture of diastereomers: $R_{f}$ $(30 \%$ EtOAc/hexanes $)=0.20 ;[\alpha]_{\mathrm{D}}^{21}=-26.8\left(c=1.0, \mathrm{CH}_{2} \mathrm{Cl}_{2}\right)$;

As an inseparable mixture of stereo-isomers: 
IR (thin film, $\mathrm{cm}^{-1}$ ) 2934, 1737, 1701, 1579, 1508, 1335, 1238;

Major $\alpha$-isomer: ${ }^{1} \mathrm{H}$ NMR $\left(600 \mathrm{MHz}, \mathrm{CDCl}_{3}\right) \delta 7.94(\mathrm{dd}, J=8.4,1.2 \mathrm{~Hz}, 1 \mathrm{H}), 7.40(\mathrm{dd}, J=$ 8.1, 8.1 Hz, 1H), $7.25(\mathrm{~m}, 1 \mathrm{H}), 6.94(\mathrm{~m}, 1 \mathrm{H}), 6.87(\mathrm{dd}, J=10.2,3.6 \mathrm{~Hz}, 1 \mathrm{H}), 6.10(\mathrm{~d}, J=10.2$ $\mathrm{Hz}, 1 \mathrm{H}), 5.56(\mathrm{~d}, J=3.0 \mathrm{~Hz}, 1 \mathrm{H}), 5.23(\mathrm{~d}, J=3.6 \mathrm{~Hz}, 1 \mathrm{H}), 5.00(\mathrm{~d}, J=0.5 \mathrm{~Hz}, 1 \mathrm{H}), 4.56(\mathrm{~d}, J=$ 6.6, 1H), $4.11(\mathrm{q}, J=6.6,1 \mathrm{H}), 4.06(\mathrm{~m}, 1 \mathrm{H}), 3.963(\mathrm{~s}, 3 \mathrm{H}), 3.96(\mathrm{~s}, 3 \mathrm{H}), 3.73-3.58(\mathrm{~m} \mathrm{2H}), 3.52-$ $3.45(\mathrm{~m} 2 \mathrm{H}), 2.70(\mathrm{dd}, J=13.2,5.4, \mathrm{~Hz}, 1 \mathrm{H}), 2.2-1.80(\mathrm{~m}, 2 \mathrm{H}), 2.10(\mathrm{~s}, 3 \mathrm{H}), 1.4-1.19(\mathrm{~m}, 2 \mathrm{H})$, $1.32(\mathrm{~d}, J=6.6,3 \mathrm{H}), 1.26(\mathrm{~d}, J=6.6,3 \mathrm{H}), 1.21(\mathrm{~d}, J=6.6,3 \mathrm{H})$;

${ }^{13} \mathrm{C}$ NMR for the Major $\alpha$-isomer could not be determined:

CIHRMS Calcd for $\left[\mathrm{C}_{32} \mathrm{H}_{39} \mathrm{BrNaO}_{11}\right]^{+}:$701.1573, Found 701.1570. 


\section{D: Experimental Procedures for Chapter III:}

\section{Methyl 4-(benzyloxy)-2-hydroxybenzoate (61) ${ }^{\S}$}

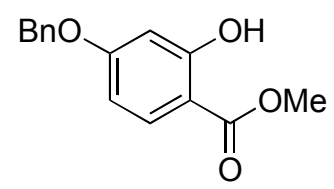

Methyl 2,4-dihydroxy-benzoate 60 (20.0 g, $119 \mathrm{mmol})$ was dissolved in $240 \mathrm{ml}$ of acetone, followed by adding tetrabutylammonium iodide $(0.132 \mathrm{~g}, 0.357 \mathrm{mmol})$, potassium carbonate (16.4 g, $119 \mathrm{mmol}$ ) and benzyl bromide (22.4 g, $131 \mathrm{~mol})$. Resulting solution was heated up to reflux for 5 hours. After cooling off to room temperature, the reaction solution was filtered and concentrated under reduced pressure to give a light yellow solid, which was dissolved again in ethyl acetate. This ethyl acetate solution was washed with water $(3 \times 200 \mathrm{ml})$ and brine $(200 \mathrm{ml})$, and concentrated to give white solid. The resulting solid was purified by recrystallization from methanol to give a white solid 61 (26.3 g, $102 \mathrm{mmol})$. Yield: $86 \%$. mp $103-105{ }^{\circ} \mathrm{C} .{ }^{1} \mathrm{H}$ NMR $\left(270 \mathrm{MHz}, \mathrm{CDCl}_{3}\right): \delta 11.0(\mathrm{~s}, 1 \mathrm{H}), 7.74(\mathrm{~d}, J=9.4 \mathrm{~Hz}, 1 \mathrm{H}), 7.37-7.40(\mathrm{~m}, 5 \mathrm{H}), 6.48-6.53(\mathrm{~m}$, 2H), $5.07(\mathrm{~s}, 2 \mathrm{H}), 3.90(\mathrm{~s}, 3 \mathrm{H})$.

\footnotetext{
$\S \S$ This procedure provided material with melting point and 1HNMR that matched that reported in the literature, see: K. Tangdenpaisal, S. Sualek, S. Ruchirawat and P. Ploypradith Tetrahedron 2009, 65, 4316-4325.
} 
Methyl 4-(benzoloxy)-2-(trifluromethylsulfonyloxy)benzoate (62)

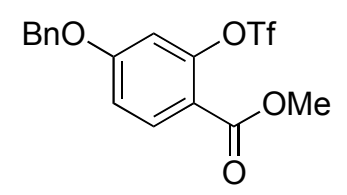

To a solution of $8.31 \mathrm{~g}(32.2 \mathrm{mmol})$ of methyl 4-(benzyloxy)-2-hydroxybenzoate 61 and 16.55 $\mathrm{ml}$ of pyridine $(16.6 \mathrm{mmol})$ at $-10{ }^{\circ} \mathrm{C}$ was added dropwise $10.0 \mathrm{~g}(35.4 \mathrm{mmol})$ of trifluoromethanesulfonic anhydride. After $10 \mathrm{~min}$ of stirring at $-10{ }^{\circ} \mathrm{C}$ followed by an additional $2 \mathrm{~h}$ of stirring at room temperature, the reaction mixture was heated up to $40{ }^{\circ} \mathrm{C}$ for 24 hours. The reaction mixture was then poured into a mixture of $200 \mathrm{ml}$ water and $200 \mathrm{ml}$ ether. The organic layer was separated, washed with water $(200 \mathrm{ml} \times 2), 10 \% \mathrm{HCl}$ solution $(200 \mathrm{ml} \times 2)$ and brine $(200 \mathrm{ml})$, dried over anhydrous sodium sulfate and concentrated under reduced pressure. The residue was purified by flash chromatography (5\% ether in hexane) to give $\mathbf{6 2}$ as a white solid (11.91 g, $30.3 \mathrm{mmol}, 95 \%): \operatorname{mp~56-57~}{ }^{\circ} \mathrm{C}$; IR 1729, 1616, 1426, 1134, 862; ${ }^{1} \mathrm{H}$ NMR (600 $\left.\mathrm{MHz}, \mathrm{CDCl}_{3}\right) \delta 8.06(\mathrm{~d}, J=9.0 \mathrm{~Hz}, 1 \mathrm{H}), 7.39(\mathrm{~m}, 5 \mathrm{H}), 7.03(\mathrm{dd}, J=9.0,1.8 \mathrm{~Hz}, 1 \mathrm{H}), 6.87(\mathrm{~d}, J$ $=1.8 \mathrm{~Hz}, 1 \mathrm{H}), 5.13(\mathrm{~s}, 2 \mathrm{H}), 3.93(\mathrm{~s}, 3 \mathrm{H}) ;{ }^{13} \mathrm{C} \mathrm{NMR}\left(150 \mathrm{MHz}, \mathrm{CDCl}_{3}\right)$ 163.9, 163.0, 149.5, 135.1, 134.1, 128.8, 128.6, 127.5, 119.8, 116.5, 114.2, 109.7, 70.9, 52.3; HRCIMS Calcd for $\left[\mathrm{C}_{11} \mathrm{H}_{16} \mathrm{O}_{5} \mathrm{H}^{+}\right]:$391.0458, Found 391.0455. 
Methyl 4-(benzyloxy)-2-(prop-1-ynyl)benzoate (63)

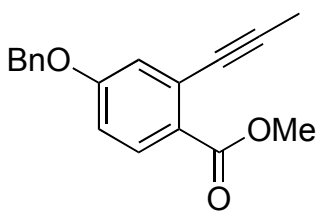

A mixture of triflate $62(13.8 \mathrm{~g}, 35.4 \mathrm{mmol}), \mathrm{Pd}\left(\mathrm{PPh}_{3}\right)_{2} \mathrm{Cl}_{2}(2.48 \mathrm{~g}, 3.54 \mathrm{mmol})$ and $\mathrm{CuI}(1.35 \mathrm{~g}$, $7.08 \mathrm{mmol}$ ) was combined in a flask topped with dry ice trap and was vacuumed for $10 \mathrm{~min}, 18.5$ $\mathrm{ml}$ of $N, N$-diisopropylethylamine $(106.3 \mathrm{mmol})$ was added via a syringe followed by adding 110 ml DMF. The dry-ice trap was filled with dry ice to cool down the system, and large excess of gaseous propyne was added using balloons. After 24 hours at room temperature, the DMF was removed by vacuum. The residue was purified by flash chromatography ( $5 \%$ ether in hexane) to give product $63(8.95 \mathrm{~g}, 32 \mathrm{mmol}, 90 \%)$ as a white solid: $\mathrm{mp} 75-77{ }^{\circ} \mathrm{C}$; IR $2944,1718,1591$, 1248, 752; ${ }^{1} \mathrm{H}$ NMR (600 MHz, $\left.\mathrm{CDCl}_{3}\right) 7.89(\mathrm{~d}, J=9.0 \mathrm{~Hz}, 1 \mathrm{H}), 7.37(\mathrm{~m}, 5 \mathrm{H}), 7.10(\mathrm{~d}, J=3.0$ $\mathrm{Hz}, 1 \mathrm{H}), 6.90(\mathrm{dd}, J=9.0,3.0 \mathrm{~Hz}, 1 \mathrm{H}), 5.09(\mathrm{~s}, 2 \mathrm{H}), 3.88(\mathrm{~s}, 3 \mathrm{H}), 2.13(\mathrm{~s}, 3 \mathrm{H}) ;{ }^{13} \mathrm{C}$ NMR $(150$ $\left.\mathrm{MHz}, \mathrm{CDCl}_{3}\right) 166.3,161.1,136.1,132.4,128.7,128.2,127.5,126.7,124.2,119.7,114.4,91.6$, 78.5, 70.1, 51.8, 4.8; CIHRMS Calcd for $\left[\mathrm{C}_{18} \mathrm{H}_{16} \mathrm{O}_{3} \mathrm{H}\right]^{+}:$281.1172. Found 281.1171. 


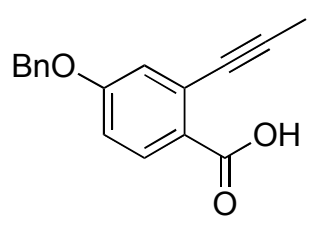

Ester 63 (3.03 g, $10.82 \mathrm{mmol})$ was dissolved in $325 \mathrm{ml}$ of methanol at room temperature, stirred until the solution was clear. $108 \mathrm{ml}$ water was added followed by the addition of $\mathrm{LiOH}$ monohydrate $(4.54 \mathrm{~g}, 108.2 \mathrm{mmol})$. Track the reaction by TLC. After 14 hours, the reaction was diluted with ammonium chloride until the $\mathrm{pH}$ reached $\sim 8$, followed by adding $10 \% \mathrm{HCl}$ solution until the $\mathrm{pH}$ reached $\sim 4$. Leave the flask in iced bath for about 20 minutes. Collect the white solid appeared during acidification by filtration. The solid was purified by flash chromatography (50\% ethyl acetate in hexane) to give product $64(2.06 \mathrm{~g}, 7.74 \mathrm{mmol}, 72 \%)$ as a white solid: $\mathrm{mp}$ 175-176 ${ }^{\circ} \mathrm{C}$; IR 3840, 2971, 1686, 1367, 1217; ${ }^{1} \mathrm{H}$ NMR $\left(600 \mathrm{MHz}, \mathrm{CDCl}_{3}\right) 8.06(\mathrm{~d}, J=9.0 \mathrm{~Hz}$, 1H), $7.39(\mathrm{~m}, 5 \mathrm{H}), 7.13(\mathrm{~d}, J=2.4 \mathrm{~Hz}, 1 \mathrm{H}), 6.90(\mathrm{dd}, J=9.0,2.4 \mathrm{~Hz}, 1 \mathrm{H}), 5.12(\mathrm{~s}, 2 \mathrm{H}), 2.16(\mathrm{~s}$, $3 \mathrm{H}) ;{ }^{13} \mathrm{C} \mathrm{NMR}\left(150 \mathrm{MHz}, \mathrm{CDCl}_{3}\right)$ 168.0, 161.8, 135.9, 133.7, 128.7, 128.3, 127.5, 126.1, 123.0, 119.7, 114.9, 93.7, 78.1, 70.2, 4.8; CIHRMS Calcd for $\left[\mathrm{C}_{17} \mathrm{H}_{14} \mathrm{O}_{3} \mathrm{H}\right]^{+}:$267.1016. Found 267.1015. 


\section{(4-benzyloxy)-2-(prop-1-ynyl)benzoylazide (67)}

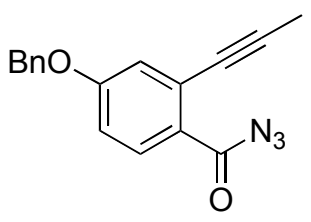

The solution of carboxylic acid $64(200 \mathrm{mg}, 0.75 \mathrm{mmol})$ in $2 \mathrm{ml}$ benzene was cooled down to 0 ${ }^{\circ} \mathrm{C}$, triethylamine $(0.11 \mathrm{~mL}, 0.79 \mathrm{mmol})$ and DPPA $66(0.163 \mathrm{~mL}, 0.752 \mathrm{mmol})$ were added. After 2 hours of stirring at room temperature, the reaction mixture was poured into $10 \mathrm{ml}$ cold water, extracted with ether $(3 \times 20 \mathrm{ml})$. The organic layers were combined, dried over sodium sulfate anhydrous and concentrated. The resulting light yellow solid 67 was dried under a vacuum for 1-2 hours and used in the next step without further purification. mp $104-106{ }^{\circ} \mathrm{C}$; IR 2921, 2142, 1683, 1523, 1292, 1186, 877; ${ }^{1} \mathrm{H} \mathrm{NMR}\left(600 \mathrm{MHz}, \mathrm{CDCl}_{3}\right) 8.05(\mathrm{~d}, J=9.0 \mathrm{~Hz}, 1 \mathrm{H})$, $7.34(\mathrm{~m}, 5 \mathrm{H}), 6.96(\mathrm{~d}, J=3.0 \mathrm{~Hz}, 1 \mathrm{H}), 6.92(\mathrm{dd}, J=9.0,3.0 \mathrm{~Hz}, 1 \mathrm{H}), 5.00(\mathrm{~s}, 2 \mathrm{H}), 2.11(\mathrm{~s}, 3 \mathrm{H})$; ${ }^{13} \mathrm{C}$ NMR (150 MHz, $\left.\mathrm{CDCl}_{3}\right)$ 154.6, 153.5, 136.6, 131.7, 128.6, 128.0, 127.4, 119.8, 117.5, 115.9, 114.2, 93.6, 74.5, 70.3, 4.5; CIHRMS Calcd for $\left[\mathrm{C}_{17} \mathrm{H}_{13} \mathrm{~N}_{3} \mathrm{O}_{2} \mathrm{H}\right]^{+}$: 292.1081. Found 292.1082 . 


\section{4-(benzyloxy-1-isocyanato-2-ynyl) benzene (68)}

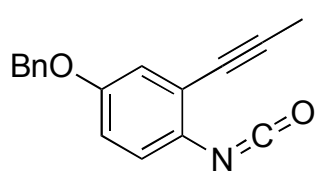

A solution of compound $67(146 \mathrm{mg}, 0.5 \mathrm{mmol})$ in $4 \mathrm{ml}$ toluene was heated up to $95{ }^{\circ} \mathrm{C}$ for around 4 hours (TLC was used to track the reaction). The toluene was removed by vacuum. The residue was dissolved in ether with the remaining solid being filter off. The solution was concentrated to give $\mathbf{6 8}$ as a light yellow solid (132 $\mathrm{mg}, 0.5 \mathrm{mmol})$. The crude isocyanate was used without further purification. mp $104-106{ }^{\circ} \mathrm{C}$; IR 2280, 1193, 834, 758, 698; ${ }^{1} \mathrm{H}$ NMR $(600$ $\left.\mathrm{MHz}, \mathrm{CDCl}_{3}\right) 7.35(\mathrm{~m}, 5 \mathrm{H}), 6.96(\mathrm{~d}, J=3.0 \mathrm{~Hz}, 1 \mathrm{H}), 6.89(\mathrm{~d}, J=9.0 \mathrm{~Hz}, 1 \mathrm{H}), 6.80(\mathrm{dd}, J=9.0$, $3.0 \mathrm{~Hz}, 1 \mathrm{H}), 5.00(\mathrm{~s}, 2 \mathrm{H}), 2.10(\mathrm{~s}, 3 \mathrm{H}) ;{ }^{13} \mathrm{C} \mathrm{NMR}\left(150 \mathrm{MHz}, \mathrm{CDCl}_{3}\right)$ 156.0, 136.5, 128.6, 128.5, 128.1, 127.4, 127.3, 124.2, 122.2, 117.5, 115.8, 95.2, 75.7, 70.4, 4.4; CIHRMS Calcd for $\left[\mathrm{C}_{17} \mathrm{H}_{13} \mathrm{NO}_{2} \mathrm{H}\right]^{+}:$264.1019. Found 292.1019. 


\section{9-(benzyloxy)-11-methyl-6H-indolo(2,3-b)(1,6)naphthyridine (71)}

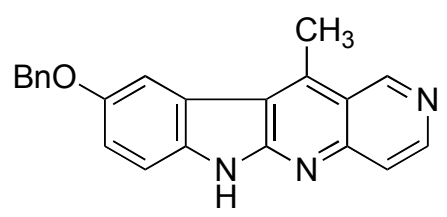

Isocyanate 68 (130 mg, $0.49 \mathrm{mmol})$ was dissolved in $20 \mathrm{ml}$ of dry p-xylene, followed by addition of iminophosphorane 69 (192 mg, $0.54 \mathrm{mmol})$. Resulting solution was heated up under reflux for 15 hours after was stirred at room temperature under argon protection for 2 hours. Para-xylene was removed by vacuum, after three cycles of washing the concentrated residue with diethyl ether, centrifugation, and decanting the supernatant liquid, the residual solid was heated under reflux in $100 \mathrm{ml}$ of benzene for 1 hour. The mixture was allowed to cool to room temperature followed by centrifugation and decanting the supernatant liquid. The remaining solid was pumped to dryness in vacuo to afford 71 (40 $\mathrm{mg}, 0.12 \mathrm{mmol}, 24 \%)$ as a yellow solid: compound turned black without melting at $311{ }^{\circ} \mathrm{C}$; IR 2645, 1602, 1480, 1219, 820; ${ }^{1} \mathrm{H}$ NMR (600 MHz, DMSO) $11.83(\mathrm{~s}, 1 \mathrm{H}), 9.68(\mathrm{~s}, 1 \mathrm{H}), 8.61(\mathrm{~d}, J=6.0 \mathrm{~Hz}, 1 \mathrm{H}), 7.94(\mathrm{~d}, J=9.0 \mathrm{~Hz}, 1 \mathrm{H}), 7.76(\mathrm{~d}, J$ $=6.0 \mathrm{~Hz}, 1 \mathrm{H}), 7.54(\mathrm{~d}, J=9.0 \mathrm{~Hz}, 1 \mathrm{H}), 7.43(\mathrm{~m}, 5 \mathrm{H}), 7.30(\mathrm{dd}, J=9.0,3.0 \mathrm{~Hz}, 1 \mathrm{H}), 5.26(\mathrm{~s}$, 2H), 3.25 (s, 3H); ${ }^{13} \mathrm{C}$ NMR (150 MHz, DMSO) 155.2, 153.4, 150.2, 149.3, 145.8, 141.0, 137.9, 136.3, 128.9, 128.3, 128.2, 121.9, 120.7, 119.8, 117.7, 117.2, 112.2, 110.1, 70.8, 14.7; CIHRMS Calcd for $\left[\mathrm{C}_{22} \mathrm{H}_{17} \mathrm{~N}_{3} \mathrm{OH}\right]^{+}:$340.1444. Found 340.1443. 


\section{Methyl 4-(benzyloxy)-2-(3-hydroxyprop-1-ynyl)benzoate (75)}

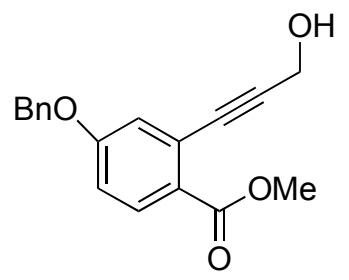

To a solution of triflate $62(195 \mathrm{mg}, 0.5 \mathrm{mmol})$, diethylamine $(1.03 \mathrm{ml}, 10 \mathrm{mmol})$ and tetra-nbutylammonium iodide $(554 \mathrm{mg}, \quad 1.5 \mathrm{mmol})$ in $\mathrm{DMF} \quad\left(\begin{array}{ll}1 & \mathrm{ml}\end{array}\right)$ were added dichlorobis(triphenylphosphine) palladium (14 mg, $0.02 \mathrm{mmol})$ and copper iodide (11.4 $\mathrm{mg}, 0.06$ mmol). The reaction mixture was stirred for $5 \mathrm{~min}$ at room temperature, and propargyl alcohol $(0.058 \mathrm{ml}, 1 \mathrm{mmol})$ was added at same temperature. Temperature was raised to $70{ }^{\circ} \mathrm{C}$, and the reaction was stirred for 4 hours. After the mixture was cooled down to room temperature, $20 \mathrm{ml}$ saturated ammonium chloride was added to reaction mixture, and extracted with ether $(3 \times 50$ $\mathrm{ml})$. Organic layers were combined, washed with brine $(100 \mathrm{ml})$, dried over anhydrous sodium sulfate and concentrated under reduced pressure. The residue was purified by flash chromatography (20\% ether in hexane) to give 75 as a white solid (117 mg, $0.40 \mathrm{mmol}, 79 \%)$ : mp 90-91 ${ }^{\circ} \mathrm{C}$; IR 1708, 1594, 1198, 1006, 784; ${ }^{1} \mathrm{H}$ NMR $\left(600 \mathrm{MHz}, \mathrm{CDCl}_{3}\right) 7.90(\mathrm{~d}, J=9.0 \mathrm{~Hz}$, 1H), $7.36(\mathrm{~m}, 5 \mathrm{H}), 7.10(\mathrm{~d}, J=3.0 \mathrm{~Hz}, 1 \mathrm{H}), 6.91(\mathrm{dd}, J=9.0,3.0 \mathrm{~Hz}, 1 \mathrm{H}), 5.06(\mathrm{~s}, 2 \mathrm{H}), 4.53(\mathrm{~s}$, 2H), $3.96(\mathrm{~s}, 3 \mathrm{H}) ; 2.26(\mathrm{~s}, 1 \mathrm{H}){ }^{13} \mathrm{C} \mathrm{NMR}\left(150 \mathrm{MHz}, \mathrm{CDCl}_{3}\right)$ 166.0, 161.2, 135.8, 132.4, 128.6, 128.2, 127.4, 125.4, 123.9, 119.5, 115.0, 93.0, 84.0, 70.1, 51.9, 51.5; CIHRMS Calcd for $\left[\mathrm{C}_{18} \mathrm{H}_{16} \mathrm{O}_{4} \mathrm{H}\right]^{+}:$297.1121. Found 297.1122. 


\section{Methyl 4-(benzyloxy)-2-(3-(tert-butyldimethylsilyloxy)prop-1-ynyl)benzoate (74)}

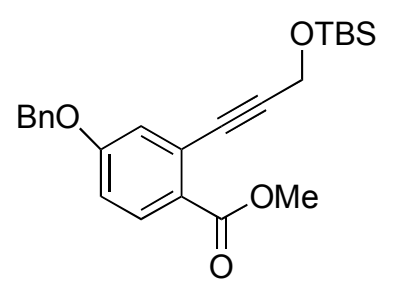

To a solution of triflate $62(195 \mathrm{mg}, 0.5 \mathrm{mmol})$, diethylamine $(1.03 \mathrm{ml}, 10 \mathrm{mmol})$ and tetra-nbutylammonium iodide $(554 \mathrm{mg}, 1.5 \mathrm{mmol})$ in $\mathrm{DMF}(1 \mathrm{ml})$ were added dichlorobis(triphenylphosine) palladium (14 mg, $0.02 \mathrm{mmol})$ and copper iodide $(11.4 \mathrm{mg}, 0.06$ mmol). The reaction mixture was stirred for $5 \mathrm{~min}$ at room temperature, and TBS protected propargyl alcohol $(0.20 \mathrm{ml}, 1 \mathrm{mmol})$ was added at same temperature. After being stirred at $70^{\circ} \mathrm{C}$ for 4 hours, the mixture was cooled down to room temperature, and $20 \mathrm{ml}$ saturated ammonium chloride was added to reaction mixture, extracted with ether $(3 \times 50 \mathrm{ml})$. Organic layers were combined, washed with brine $(100 \mathrm{ml})$, dried over anhydrous sodium sulfate and concentrated under reduced pressure. The residue was purified by flash chromatography ( $20 \%$ ether in hexane) to give 74 as a light yellow liquid (165 mg, $0.40 \mathrm{mmol}, 81 \%$ ): IR 2953, 2252, 1721, 1597, 1251, 905, 695; ${ }^{1} \mathrm{H} \mathrm{NMR}\left(600 \mathrm{MHz}, \mathrm{CDCl}_{3}\right) 7.89(\mathrm{~d}, J=9.0 \mathrm{~Hz}, 1 \mathrm{H}), 7.36(\mathrm{~m}, 5 \mathrm{H}), 7.11(\mathrm{~d}, J=3.0 \mathrm{~Hz}$, 1H), $6.91(\mathrm{dd}, J=9.0,3.0 \mathrm{~Hz}, 1 \mathrm{H}), 5.07(\mathrm{~s}, 2 \mathrm{H}), 4.60(\mathrm{~s}, 2 \mathrm{H}), 3.86(\mathrm{~s}, 3 \mathrm{H}), 0.93(\mathrm{~s}, 9 \mathrm{H}), 0.16$ (s, $6 \mathrm{H}) ;{ }^{13} \mathrm{C} \mathrm{NMR}\left(150 \mathrm{MHz}, \mathrm{CDCl}_{3}\right)$ 166.0, 161.0, 135.9, 132.4, 128.6, 128.2, 127.4, 125.4, 124.3, 119.7, 114.9, 93.0, 83.3, 70.1, 52.4, 51.8, 25.8, 18.3, -5.14; CIHRMS Calcd for $\left[\mathrm{C}_{24} \mathrm{H}_{30} \mathrm{O}_{4} \mathrm{SiH}\right]^{+}$: 411.1986. Found 411.1989. 


\section{Methyl 4-(benzyloxy)-2-(3-(triisopropylsilyloxy)prop-1-ynyl)benzoate (76)}

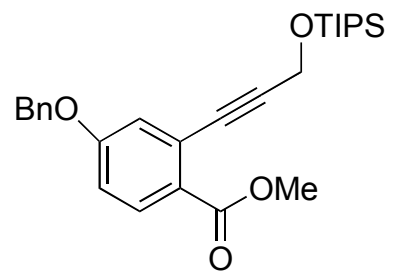

Compound 75 (148 mg, $0.5 \mathrm{mmol}$ ) was dissolved in $1 \mathrm{ml}$ methylene chloride, TIPS chloride (116 $\mathrm{mg}, 0.6 \mathrm{mmol})$, triethylamine $(0.14 \mathrm{ml}, 1 \mathrm{mmol})$ and DMAP $(6 \mathrm{mg}, 0.05 \mathrm{mmol})$ were added. The reaction mixture was poured into $10 \mathrm{ml}$ of water after stirring overnight at room temperature, and was extracted by ether $(3 \times 50 \mathrm{ml})$. The residue was purified by flash chromatography $(10 \%$ ether in hexane) to give 76 as a light yellow liquid (226 mg, $0.50 \mathrm{mmol}, 100 \%$ ): IR 2924, 1694, 1593, 1365, 1216, 882; ${ }^{1} \mathrm{H}$ NMR (600 MHz, $\left.\mathrm{CDCl}_{3}\right) 7.89$ (d, $\left.J=9.0 \mathrm{~Hz}, 1 \mathrm{H}\right), 7.36(\mathrm{~m}, 5 \mathrm{H}), 7.11(\mathrm{~d}, J$ $=3.0 \mathrm{~Hz}, 1 \mathrm{H}), 6.91(\mathrm{dd}, J=9.0,3.0 \mathrm{~Hz}, 1 \mathrm{H}), 5.07(\mathrm{~s}, 2 \mathrm{H}), 4.66(\mathrm{~s}, 2 \mathrm{H}), 3.86(\mathrm{~s}, 3 \mathrm{H}), 1.10(\mathrm{~s}$, 18H), 1.09 (s, 3H); ${ }^{13} \mathrm{C}$ NMR (150 MHz, $\left.\mathrm{CDCl}_{3}\right)$ 166.1, 161.1, 136.0, 132.4, 128.7, 128.2, 127.5, 125.5, 124.3, 119.7, 114.9, 93.2, 83.1, 70.2, 52.7, 51.8, 17.9, 12.0; CIHRMS Calcd for $\left[\mathrm{C}_{27} \mathrm{H}_{36} \mathrm{O}_{4} \mathrm{SiH}\right]^{+}:$453.2456. Found 453.2460. 


\section{4-(benzyloxy)-2-(3-(triisopropylsilyloxy)prop-1-ynyl)benzoic acid (77)}

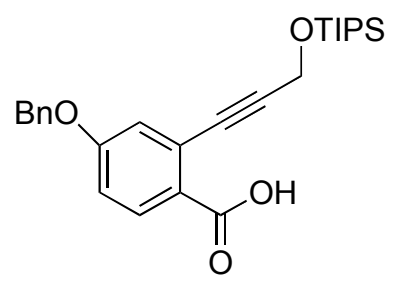

Compound 76 (928 mg, $2.05 \mathrm{mmol}$ ) was dissolved in $60 \mathrm{ml}$ methanol/20 $\mathrm{ml}$ water, and lithium hydroxide monohydrate $(1.29 \mathrm{~g}, 30.8 \mathrm{mmol})$ was added after all solid dissoved. The resulting reaction mixture was stirred at room temperature for 15 hours. The solvent was removed by reduced pressure, the solid left behind was dissolved in $100 \mathrm{ml}$ of water, $10 \% \mathrm{HCl}$ solution was used to adjust $\mathrm{PH}$ to about 3 . Extracted the water solution with ether $(3 \times 200 \mathrm{ml})$, ether was combined, dried over anhydrous sodium sulfate and concentrated under reduced pressure. The solid was purified by flash chromatography (20\% ether in hexane) to give 77 as a white solid (264 mg, $0.60 \mathrm{mmol}, 55 \%$ based on reacted starting material): m.p. $112-114{ }^{\circ} \mathrm{C}$; IR 2944,1727 , 1597, 1328, 1283, 1190, 1068, 882; ${ }^{1} \mathrm{H}$ NMR (600 MHz, $\left.\mathrm{CDCl}_{3}\right) 8.02(\mathrm{~d}, J=9.0 \mathrm{~Hz}, 1 \mathrm{H}), 7.36$ $(\mathrm{m}, 5 \mathrm{H}), 7.13(\mathrm{~d}, J=3.0 \mathrm{~Hz}, 1 \mathrm{H}), 6.95(\mathrm{dd}, J=9.0,3.0 \mathrm{~Hz}, 1 \mathrm{H}), 5.10(\mathrm{~s}, 2 \mathrm{H}), 4.66(\mathrm{~s}, 2 \mathrm{H}), 1.10$ (s, 18H), 1.09 (s, 3H); ${ }^{13} \mathrm{C}$ NMR (150 MHz, $\left.\mathrm{CDCl}_{3}\right)$ 169.8, 161.7. 135.9, 133.5, 128.7, 128.3, $127.5,125.9,123.2,119.9,115.1,94.4,82.8,70.3,52.7,17.9,12.1$; CIHRMS Calcd for $\left[\mathrm{C}_{26} \mathrm{H}_{34} \mathrm{O}_{4} \mathrm{SiH}\right]^{+}:$439.2299. Found 453.2302. 


\section{Camptothecin Acetate (90): ${ }^{* * *}$}

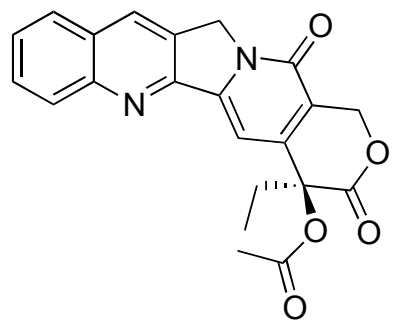

CPT (500 mg) and $\mathrm{LiBr}(500 \mathrm{mg})$ was dissolved in $\mathrm{Ac}_{2} \mathrm{O}(5 \mathrm{~mL})$, then the resulting mixture was stirred for $48 \mathrm{~h}$ at $80{ }^{\circ} \mathrm{C}$. After cooling to room temperature, $30 \mathrm{~mL}$ of hexane was added to the reaction mixture while stirring. The product precipitated from hexane was collected by filtration and washed with $45 \mathrm{~mL}$ of hexane $(15 \mathrm{~mL} \times 3)$. After drying under air for $1 \mathrm{~h}$, a gray-white powder 90 (515 mg, 92\%) was obtained. $\mathrm{mp} 273{ }^{\circ} \mathrm{C}$; IR (thin film, $\mathrm{cm}^{-1}$ ) 3011, 1748, 1668, 1657, 1618, 1229, 1047, 751, 744, 723; ${ }^{1} \mathrm{H} \mathrm{NMR}\left(\mathrm{CDCl}_{3}, 600 \mathrm{MHz}\right) \delta 8.42(\mathrm{~s}, 1 \mathrm{H}), 8.26(\mathrm{~d}, J=8.4 \mathrm{~Hz}$, 1H), $7.95(\mathrm{~d}, J=8.4 \mathrm{~Hz}, 1 \mathrm{H}), 7.85(\mathrm{dd}, J=7.2 \mathrm{~Hz}, 1 \mathrm{H}), 7.69(\mathrm{dd}, J=7.2 \mathrm{~Hz}, 1 \mathrm{H}), 7.29(\mathrm{~s}, 1 \mathrm{H})$, $5.67(\mathrm{~d}, J=17.4 \mathrm{~Hz}, 1 \mathrm{H}), 5.41(\mathrm{~d}, J=17.4 \mathrm{~Hz}, 1 \mathrm{H}), 5.29(\mathrm{~d}, J=17.4 \mathrm{~Hz}, 2 \mathrm{H}), 2.29(\mathrm{~m}, 1 \mathrm{H})$, $2.23(\mathrm{~s}, 3 \mathrm{H}), 2.15(\mathrm{~m}, 1 \mathrm{H}), 0.98(\mathrm{t}, J=7.2 \mathrm{~Hz}, 3 \mathrm{H}) ;{ }^{13} \mathrm{C} \mathrm{NMR}\left(\mathrm{CDCl}_{3}, 150 \mathrm{MHz}\right) \delta 170.1,167.7$, $157.6,152.5,148.9,146.2,146.1,131.6,131.0,129.7,128.7,128.5,128.3,120.7,96.4,76.1$, 67.3, 50.1, 32.1, 21.0, 7.8. CIHRMS: Calculated for $\left[\mathrm{C}_{22} \mathrm{H}_{18} \mathrm{~N}_{2} \mathrm{O}_{5} \mathrm{Na}^{+}\right]$: 413.1113. Found: 413.1109.

\footnotetext{
${ }^{* * *}$ This procedure provided material with melting point, IR, ${ }^{1} \mathrm{H}$ NMR, and ${ }^{13} \mathrm{C}$ NMR that matched that reported in the literature, see: N. Ravindranath, C. Ramesh, M. R. Reddy, K. V. N. S. Srinivas, and B. Das Syn. Commun. 2003, $33,4029-4035$.
} 


\section{Camptothecin Acetate $N$-oxide (91):}

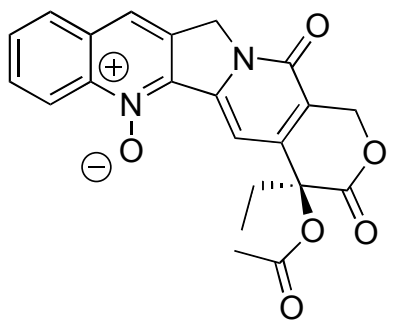

A solution of compound $90(500 \mathrm{mg})$ in EtOAc $(15 \mathrm{~mL})$ and $\mathrm{CH}_{2} \mathrm{Cl}_{2}(15 \mathrm{~mL})$ was added excess $75 \%$ mCPBA ( $2 \mathrm{~g})$, and the reaction mixture was stirred at $80^{\circ} \mathrm{C}$ for $24 \mathrm{~h}$. After cooling to room temperature, the reaction was washed with $1 \mathrm{~N} \mathrm{NaOH}(2 \times 15 \mathrm{~mL})$, then saturated $\mathrm{NaHCO}_{3}(15$ $\mathrm{mL}$ ). The organic layer was washed with $\mathrm{H}_{2} \mathrm{O}$ and brine, dried with $\mathrm{Na}_{2} \mathrm{SO}_{4}$ and evaporated to dryness. The crude oxide product $91(540 \mathrm{mg})$ was used without further purification. $\mathrm{mp} 239{ }^{\circ} \mathrm{C}$; IR (thin film, $\left.\mathrm{cm}^{-1}\right)$ 3563, 3022, 1748, 1660, 1619, 1609, 1231, 1049, 749; ${ }^{1} \mathrm{H} \mathrm{NMR}\left(\mathrm{CDCl}_{3}, 600\right.$ MHz) $\delta 8.76(\mathrm{~d}, J=8.4 \mathrm{~Hz}, 1 \mathrm{H}), 7.99(\mathrm{~s}, 1 \mathrm{H}), 7.96(\mathrm{~d}, J=8.4 \mathrm{~Hz}, 1 \mathrm{H}), 7.88(\mathrm{~s}, 1 \mathrm{H}), 7.85(\mathrm{dd}, J$ $=7.8 \mathrm{~Hz}, 1 \mathrm{H}), 7.74(\mathrm{dd}, J=7.8 \mathrm{~Hz}, 1 \mathrm{H}), 5.63(\mathrm{~d}, J=17.4 \mathrm{~Hz}, 1 \mathrm{H}), 5.36(\mathrm{~d}, J=17.4 \mathrm{~Hz}, 1 \mathrm{H})$, $5.27(\mathrm{~d}, J=19.8 \mathrm{~Hz}, 2 \mathrm{H}), 2.26(\mathrm{~m}, 1 \mathrm{H}), 2.19(\mathrm{~s}, 3 \mathrm{H}), 2.14(\mathrm{~m}, 1 \mathrm{H}), 0.96(\mathrm{t}, J=7.2 \mathrm{~Hz}, 3 \mathrm{H}) ;{ }^{13} \mathrm{C}$ $\mathrm{NMR}\left(\mathrm{CDCl}_{3}, 150 \mathrm{MHz}\right) \delta 170.2,167.6,157.0,146.2,142.5,141.0,137.6,131.2,130.5,130.3$, 130.0, 128.8, 121.5, 119.9, 119.3, 101.4, 75.9, 67.1, 50.6, 31.9, 20.8, 7.7; CIHRMS: Calculated for $\left[\mathrm{C}_{22} \mathrm{H}_{18} \mathrm{~N}_{2} \mathrm{O}_{6} \mathrm{Na}^{+}\right.$]: 429.1063 . Found: 429.1066 . 


\section{7-Chloro Camptothecin Acetate (92):}

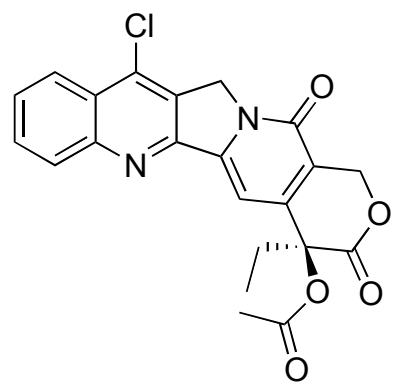

The crude oxide product $91(540 \mathrm{mg})$ in DMF $(10 \mathrm{~mL})$ was added oxalyl chloride $(0.5 \mathrm{~mL})$ dropwise. After the reaction mixture was stirred at room temperature for $2 \mathrm{~h}$, saturated $\mathrm{NaHCO}_{3}$ aqueous and $\mathrm{CH}_{2} \mathrm{Cl}_{2}$ were added. The organic layer was washed with $\mathrm{H}_{2} \mathrm{O}$ and brine, dried with $\mathrm{Na}_{2} \mathrm{SO}_{4}$ and concentrated under reduced pressure to give a residue, which was purified by column chromatography (silica; chloroform/acetone, 50:1 20:1) to afford the desired compound 92 (410 mg, 76\%) as a yellow solid. $\mathrm{mp} 267^{\circ} \mathrm{C}$; IR (thin film, $\mathrm{cm}^{-1}$ ) 3003, 1762, 1745, 1664, 1618, 1231, 749; ${ }^{1} \mathrm{H}$ NMR $\left(\mathrm{CDCl}_{3}, 600 \mathrm{MHz}\right) \delta 8.31(\mathrm{~d}, J=8.4 \mathrm{~Hz}, 1 \mathrm{H}), 8.25(\mathrm{~d}, J=8.4 \mathrm{~Hz}$, 1H), $7.88(\mathrm{dd}, J=7.8 \mathrm{~Hz}, 1 \mathrm{H}), 7.76(\mathrm{dd}, J=7.8 \mathrm{~Hz}, 1 \mathrm{H}), 7.25(\mathrm{~s}, 1 \mathrm{H}), 5.27(\mathrm{~d}, J=17.4 \mathrm{~Hz}, 2 \mathrm{H})$, $2.25(\mathrm{~m}, 1 \mathrm{H}), 2.20(\mathrm{~s}, 3 \mathrm{H}), 2.12(\mathrm{~m}, 1 \mathrm{H}), 0.96(\mathrm{t}, J=7.2 \mathrm{~Hz}, 3 \mathrm{H}) ;{ }^{13} \mathrm{C} \mathrm{NMR}\left(\mathrm{CDCl}_{3}, 150 \mathrm{MHz}\right) \delta$ $169.9,167.3,157.1,151.8,149.4,146.0,145.6,138.6,131.5,129.7,129.0,127.5,126.2,123.9$, 121.1, 96.9, 75.8, 67.0, 50.0, 31.7, 20.7, 7.5; HRMS (ESI) calcd. For $\left[\mathrm{C}_{22} \mathrm{H}_{17} \mathrm{ClN}_{2} \mathrm{O}_{5}+\mathrm{Na}\right]^{+}$: 447.0724, Found: 447.0718. 


\section{7-(3-Tetrahydropyranyloxy)prop-1-ynyl Camptothecin Acetate (94):}

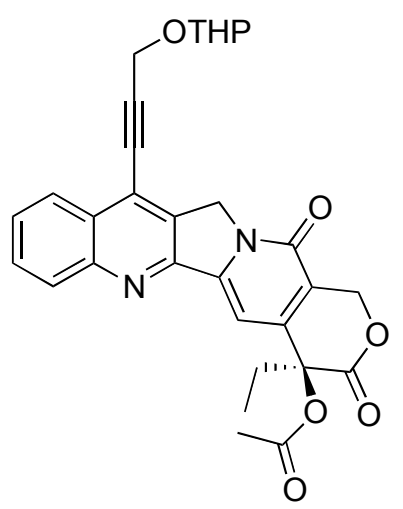

To a mixture of compound 92 (43 mg, $0.1 \mathrm{mmol}), \mathrm{Pd}(\mathrm{OAc})_{2}(0.01 \mathrm{mmol})$, rac-BINAP $(0.02$ mmol) and potassium carbonate $(56 \mathrm{mg}, 0.4 \mathrm{mmol})$, under an argon atmosphere, was added a solution of tetrahydro-2-(2-propynloxy)-2H-pyran $93(0.4 \mathrm{mmol})$ in degassed toluene $(9 \mathrm{~mL})$. After the reaction mixture was stirred at $100{ }^{\circ} \mathrm{C}$ for $6 \mathrm{~h}$, the solvent was evaporated to give a residue, which was purified by flash column chromatography on silica gel (chloroform/acetone, 50:1 20:1) to furnish compound $94(40 \mathrm{mg}, 75 \%)$ as a yellow oil solid. MP X; IR (thin film, $\mathrm{cm}^{-}$ $\left.{ }^{1}\right) 2947,1751,1668,1615,1230,1020,768 .{ }^{1} \mathrm{H} \mathrm{NMR}\left(\mathrm{CDCl}_{3}, 600 \mathrm{MHz}\right) \delta 8.34(\mathrm{~d}, J=7.8 \mathrm{~Hz}$, $1 \mathrm{H}), 8.21(\mathrm{~d}, J=7.8 \mathrm{~Hz}, 1 \mathrm{H}), 7.84(\mathrm{dd}, J=7.8 \mathrm{~Hz}, 1 \mathrm{H}), 7.71(\mathrm{dd}, J=7.8 \mathrm{~Hz}, 1 \mathrm{H}), 7.21(\mathrm{~s}, 1 \mathrm{H})$, $5.67(\mathrm{~d}, J=16.8 \mathrm{~Hz}, 1 \mathrm{H}), 5.40(\mathrm{~d}, J=16.8 \mathrm{~Hz}, 1 \mathrm{H}), 5.30(\mathrm{~d}, J=19.2 \mathrm{~Hz}, 2 \mathrm{H}), 4.96(\mathrm{t}, J=3.6 \mathrm{~Hz}$, $1 \mathrm{H}), 4.71(\mathrm{~d}, J=16.2 \mathrm{~Hz}, 2 \mathrm{H}), 3.95(\mathrm{~m}, 1 \mathrm{H}), 3.63(\mathrm{~m}, 1 \mathrm{H}), 2.27(\mathrm{~m}, 1 \mathrm{H}), 2.21(\mathrm{~s}, 3 \mathrm{H}), 2.15(\mathrm{~m}$, 1H), $1.90-1.58(\mathrm{~m}, 6 \mathrm{H}), 0.97(\mathrm{t}, J=7.2 \mathrm{~Hz}, 3 \mathrm{H}) ;{ }^{13} \mathrm{C} \mathrm{NMR}\left(\mathrm{CDCl}_{3}, 150 \mathrm{MHz}\right) \delta 170.1,167.7$, $157.5,151.8,148.9,146.3,146.1,131.2,131.1,130.1,128.8,127.9,126.2,125.5,120.9,101.4$ 97.9, 96.5, 78.6, 76.1, 67.3, 62.5, 55.0, 50.5, 32.0, 30.5, 25.5, 20.9, 19.2, 7.8; HRMS (ESI) calcd. For $\left[\mathrm{C}_{30} \mathrm{H}_{28} \mathrm{~N}_{2} \mathrm{O}_{7}+\mathrm{Na}\right]^{+}:$551.1794, Found: 551.1791 . 


\section{7-(3-Hydroxy)prop-1-ynyl Camptothecin Acetate (98):}

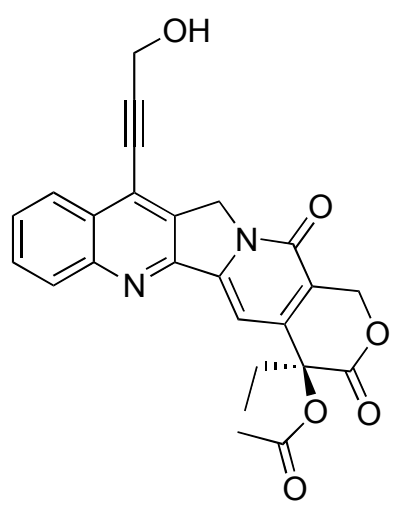

To a solution of compound $94(50 \mathrm{mg})$ in methanol $(1 \mathrm{~mL})$ and chloroform $(1 \mathrm{ml})$ was added $p$ toluenesulfonic acid $(5 \mathrm{mg})$. The reaction mixture was stirred at room temperature for $1 \mathrm{~h}$ and evaporated to dryness. The residue was added saturated aq. $\mathrm{NaHCO}_{3}$, extracted with $\mathrm{CH}_{2} \mathrm{Cl}_{2}$, and purified by flash column chromatography on silica gel (chloroform/methanol, 80:1 50:1) to furnish compound 98 (40 mg, 95\%) as a yellow solid. mp $280{ }^{\circ} \mathrm{C}$; IR (thin film, $\mathrm{cm}^{-1}$ ) 3267 (broad), 1744, 1658, 1228, 1049, 1019, 771, 723; ${ }^{1} \mathrm{H}$ NMR $\left(\mathrm{CDCl}_{3}, 600 \mathrm{MHz}\right) \delta 8.32(\mathrm{~d}, J=8.4$ Hz, 1H), 8.24 (d, $J=8.4 \mathrm{~Hz}, 1 \mathrm{H}), 7.85$ (dd, $J=7.8 \mathrm{~Hz}, 1 \mathrm{H}), 7.71$ (dd, $J=7.8 \mathrm{~Hz}, 1 \mathrm{H}), 7.27$ (s, 1H), $5.68(\mathrm{~d}, J=17.4 \mathrm{~Hz}, 1 \mathrm{H}), 5.41(\mathrm{~d}, J=17.4 \mathrm{~Hz}, 1 \mathrm{H}), 5.29(\mathrm{~d}, J=19.2 \mathrm{~Hz}, 2 \mathrm{H}), 4.75(\mathrm{~s}, 2 \mathrm{H})$, $2.27(\mathrm{~m}, 1 \mathrm{H}), 2.23(\mathrm{~s}, 3 \mathrm{H}), 2.15(\mathrm{~m}, 3 \mathrm{H}), 0.99(\mathrm{t}, J=7.8 \mathrm{~Hz}, 3 \mathrm{H}) ;{ }^{13} \mathrm{C} \mathrm{NMR}\left(\mathrm{CDCl}_{3}, 150 \mathrm{MHz}\right) \delta$ $170.1,167.7,157.5,151.6,148.6,146.3,146.1,131.4,131.2,129.9,128.9,127.8,126.2,121.0$, 97.0, 89.5, 78.4, 76.1, 67.2, 51.8, 50.6, 32.0, 20.9, 7.8; HRMS (ESI) calcd. For $\left[\mathrm{C}_{25} \mathrm{H}_{20} \mathrm{~N}_{2} \mathrm{NaO}_{6}+\mathrm{Na}\right]^{+}:$467.1219, Found: 467.1223. 


\section{O-t-butyldimetylsilyl SN38 (103):}

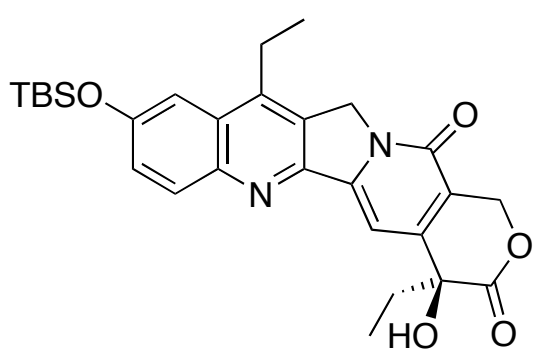

A DMF (1 mL) solution of SN-38 $(43 \mathrm{mg}, 0.1 \mathrm{mmol})$ was cooled to $0{ }^{\circ} \mathrm{C}$, and $\mathrm{Et}_{3} \mathrm{~N}$ and $\mathrm{TBSCl}$ (50 mg) were added. After stirring at $0{ }^{\circ} \mathrm{C}$ for $2 \mathrm{~h}$, the reaction was quenched by adding $5 \mathrm{~mL}$ saturated aq. $\mathrm{NaHCO}_{3}$, extracted with $\mathrm{CH}_{2} \mathrm{Cl}_{2}$, dried $\left(\mathrm{Na}_{2} \mathrm{SO}_{4}\right)$, and concentrated under reduced pressure. The crude product was purified using silica gel flash chromatography eluting with $\mathrm{CH}_{2} \mathrm{Cl}_{2} / \mathrm{MeOH}=80: 1 \sim 50: 1$ to give $44 \mathrm{mg}(83 \%)$ of compound 103 as a white solid. $\mathrm{mp}{ }^{\circ} \mathrm{C}$; IR (thin film, $\left.\mathrm{cm}^{-1}\right)$ 3003, 1762, 1745, 1664, 1618, 1231, 749; ${ }^{1} \mathrm{H} \mathrm{NMR}\left(\mathrm{CDCl}_{3}, 600 \mathrm{MHz}\right) \delta 8.11(\mathrm{~d}$, $J=8.4 \mathrm{~Hz} 1 \mathrm{H}), 7.65(\mathrm{~s}, 1 \mathrm{H}), 7.38(\mathrm{~m}, 2 \mathrm{H}), 5.64(\mathrm{~d}, J=16.2,1 \mathrm{H}), 5.30(\mathrm{~d}, J=16.2,1 \mathrm{H}), 5.23(\mathrm{~s}$ 2H), $3.81(\mathrm{~s}, 1 \mathrm{H}), 3.12(\mathrm{q}, J=7.8 \mathrm{~Hz}, 2 \mathrm{H}), 1.92(\mathrm{dq}, J=15.0,7.8 \mathrm{~Hz}, 1 \mathrm{H}), 1.86(\mathrm{dq}, J=15.0$, $7.8 \mathrm{~Hz}, 1 \mathrm{H}), 1.64(\mathrm{~s}, 1 \mathrm{H}), 1.39(\mathrm{t}, J=7.8 \mathrm{~Hz}, 3 \mathrm{H}), 1.05(\mathrm{~s}, 9 \mathrm{H}), 1.03(\mathrm{t}, J=7.2 \mathrm{~Hz}, 3 \mathrm{H}), 0.91(\mathrm{~s}$, 9H), $0.31(\mathrm{~s}, 6 \mathrm{H}) ;{ }^{13} \mathrm{C} \mathrm{NMR}\left(\mathrm{CDCl}_{3}, 150 \mathrm{MHz}\right) \delta 174.1,157.9,155.4,150.6,150.1,147.5,145.7$, $143.9,132.3,128.4,127.2,126.2,118.2,110.7,97.8,76.1,73.1,49.6,31.9,25.8,23.3,18.6,13.9$, 8.0, -4.0; HRMS (ESI) calcd. For $\left[\mathrm{C}_{28} \mathrm{H}_{34} \mathrm{~N}_{2} \mathrm{O}_{5} \mathrm{Si}+\mathrm{H}\right]^{+}:$507.2315, Found: 507.2311. 


\section{O-t-butyldimetylsilyl SN38 Acetate (104):}

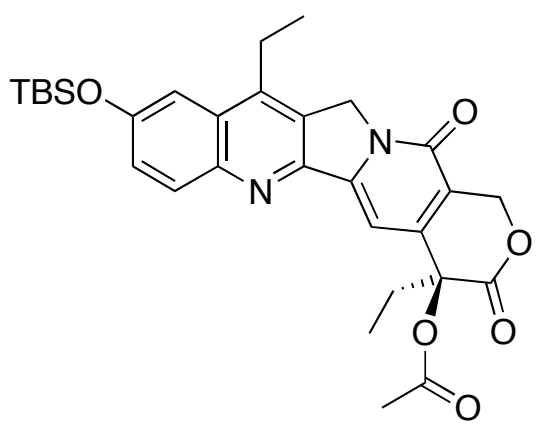

The TBS ether $103(500 \mathrm{mg})$ and $\mathrm{LiBr}(500 \mathrm{mg})$ was dissolved in $\mathrm{Ac}_{2} \mathrm{O}(5 \mathrm{~mL})$, and the resulting mixture was stirred for $48 \mathrm{~h}$ at $80{ }^{\circ} \mathrm{C}$. After cooling to room temperature, $30 \mathrm{~mL}$ of hexane was added to the reaction mixture while stirring. The product precipitated from hexane was collected by filtration and washed with $45 \mathrm{~mL}$ of hexane $(15 \mathrm{~mL} \times 3)$. After drying under air for $1 \mathrm{~h}$, a gray-white powder 104 (515 mg, 92\%) was obtained. mp $212{ }^{\circ} \mathrm{C}$; IR (thin film, $\mathrm{cm}^{-1}$ ) 3005, 1762, 1755, 1750, 1664, 1618, 1231, 749; ${ }^{1} \mathrm{H}$ NMR $\left(\mathrm{CDCl}_{3}, 600 \mathrm{MHz}\right) \delta 8.09(\mathrm{~d}, J=8.4 \mathrm{~Hz} 1 \mathrm{H}), 7.50$ (s, 1H), $7.48(\mathrm{~m}, 2 \mathrm{H}), 5.67(\mathrm{~d}, J=16.2,1 \mathrm{H}), 5.50(\mathrm{~d}, J=16.2,1 \mathrm{H}), 5.30(\mathrm{~m}, 2 \mathrm{H}), 3.21(\mathrm{q}, J=7.8$ $\mathrm{Hz}, 2 \mathrm{H}), 2.37(\mathrm{dq}, J=15.0,7.8 \mathrm{~Hz}, 1 \mathrm{H}), 2.30(\mathrm{~s}, 3 \mathrm{H}), 2.24(\mathrm{dq}, J=15.0,7.8 \mathrm{~Hz}, 1 \mathrm{H}), 1.49(\mathrm{t}, J=$ $7.8 \mathrm{~Hz}, 3 \mathrm{H}), 1.15(\mathrm{~s}, 9 \mathrm{H}), 1.08(\mathrm{t}, J=7.2 \mathrm{~Hz}, 3 \mathrm{H}), 0.42(\mathrm{~s}, 6 \mathrm{H}) ;{ }^{13} \mathrm{C} \mathrm{NMR}\left(\mathrm{CDCl}_{3}, 150 \mathrm{MHz}\right) \delta$ $170.0,167.9,157.7,155.4,150.0,147.3,146.2,145.6,144.1,132.0,128.5,127.1,126.4,119.7$, $110.8,95.7,76.1,67.3,49.5,32.0,25.9,23.3,20.9,18.5,13.9,7.74,-4.1$; HRMS (ESI) calcd. For $\left[\mathrm{C}_{30} \mathrm{H}_{36} \mathrm{~N}_{2} \mathrm{O}_{6} \mathrm{Si}+\mathrm{H}\right]^{+}:$549.2421, Found: 549.2426. 


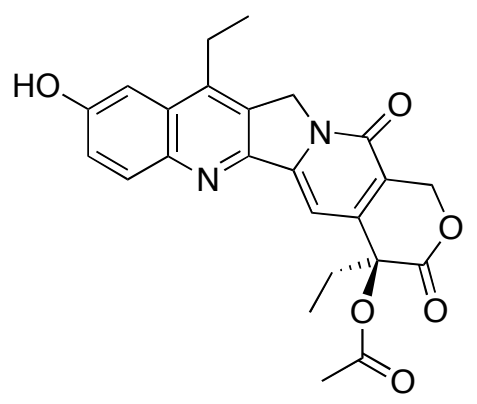

A $\mathrm{CH}_{2} \mathrm{Cl}_{2}(5 \mathrm{~mL})$ solution of compound $104(550 \mathrm{mg})$ was cooled to $0{ }^{\circ} \mathrm{C}$ and a solution of $\mathrm{HF} \cdot 2 \mathrm{Py}$. After cooling to room temperature, $30 \mathrm{~mL}$ of hexane was added to the reaction mixture while stirring. The product precipitated from hexane was collected by filtration and washed with $45 \mathrm{~mL}$ of hexane $(15 \mathrm{~mL} \times 3)$. After drying under air for $1 \mathrm{~h}$, a gray-white powder $(515 \mathrm{mg}, 92 \%)$ was obtained. Decomposes $>250{ }^{\circ} \mathrm{C}$; IR (thin film, $\mathrm{cm}^{-1}$ ) 3350, 3005, 1762, 1755, 1750, 1664 , 1618, 1231, 749; ${ }^{1} \mathrm{H}$ NMR $\left(\mathrm{CDCl}_{3} / \mathrm{CD}_{3} \mathrm{OD}, 600 \mathrm{MHz}\right) \delta 8.22(\mathrm{~d}, J=9.1 \mathrm{~Hz}, 1 \mathrm{H}), 7.83(\mathrm{~d}, J=$ $2.7 \mathrm{~Hz}, 1 \mathrm{H}), 7.58(\mathrm{dd}, J=9.1,2.7 \mathrm{~Hz}, 1 \mathrm{H}), 7.18(\mathrm{~s}, 1 \mathrm{H}), 5.68(\mathrm{~d}, J=17.0,1 \mathrm{H}), 5.41(\mathrm{~d}, J=17.0$, 1H), $5.23(\mathrm{~m}, 2 \mathrm{H}), 3.16(\mathrm{q}, J=7.6 \mathrm{~Hz}, 2 \mathrm{H}), 2.32(\mathrm{~m}, 2 \mathrm{H}), 2.20(\mathrm{~s}, 3 \mathrm{H}), 1.38(\mathrm{t}, J=7.8 \mathrm{~Hz}, 3 \mathrm{H})$, $0.99\left(\mathrm{t}, J=7.2 \mathrm{~Hz}\right.$ ); HRMS (ESI) calcd. For $\left[\mathrm{C}_{24} \mathrm{H}_{22} \mathrm{~N}_{2} \mathrm{O}_{6}+\mathrm{H}\right]^{+}: 434.1478$, Found: 434.1472.

\footnotetext{
${ }^{1 \dagger}$ This sample was not soluble enough in any mixture of $\mathrm{CDCl}_{3} / \mathrm{CD}_{3} \mathrm{OD}$ to get a good ${ }^{13} \mathrm{C}$ NMR data.
} 


\section{(4R,1'S,6'S)-4,11-diethyl-4-acetoxy-9-(6-methyl-5-0xo-6H-pyranyloxy)-1H-}

\section{Pyrano[3',4':6,7]indolizino[1,2-b]quinoline-3,14(4H,12H)-dione (105):}

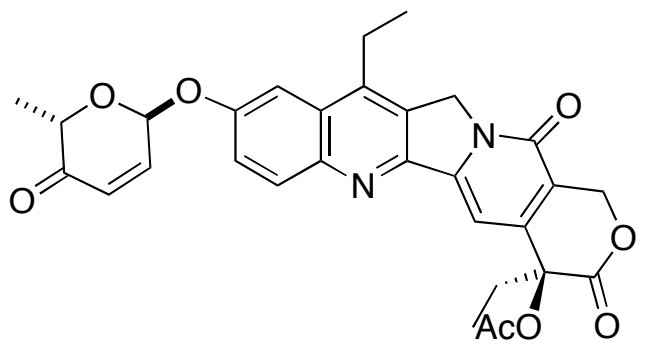

A $\mathrm{CH}_{2} \mathrm{Cl}_{2}(5 \mathrm{~mL})$ solution of compound $\mathbf{1 0 2}(43 \mathrm{mg}, 0.1 \mathrm{mmol})$ and compound $\mathbf{5}(\boldsymbol{\alpha}-\mathbf{L})(35 \mathrm{mg}$, $0.15 \mathrm{mmol})$ was cooled to $0{ }^{\circ} \mathrm{C}$. A $\mathrm{CH}_{2} \mathrm{Cl}_{2}(1 \mathrm{~mL})$ solution of $\mathrm{Pd}_{2}(\mathrm{DBA})_{3} \cdot \mathrm{CHCl}_{3}(3 \mathrm{mg}, 2.5$ mol\%) and $\mathrm{PPh}_{3}(4 \mathrm{mg}, 10 \mathrm{~mol} \%)$ was added to the reaction mixture at $0{ }^{\circ} \mathrm{C}$. The reaction mixture was stirred at $0{ }^{\circ} \mathrm{C}$ for $2 \mathrm{~h}$. The reaction mixture was quenched with $5 \mathrm{~mL}$ of saturated aq $\mathrm{NaHCO}_{3}$, extracted with $\mathrm{CH}_{2} \mathrm{Cl}_{2}$, dried $\left(\mathrm{Na}_{2} \mathrm{SO}_{4}\right)$, and concentrated under reduced pressure. The crude product was purified using silica gel flash chromatography eluting with $\mathrm{CHCl}_{3} / \mathrm{MeOH}=$ 80:1 50:1 to give $44 \mathrm{mg}$ (83\%) of compound $\mathbf{1 0 5}$.

This product was unstable and only crude ${ }^{1} \mathrm{H}$ NMR was obtained. 


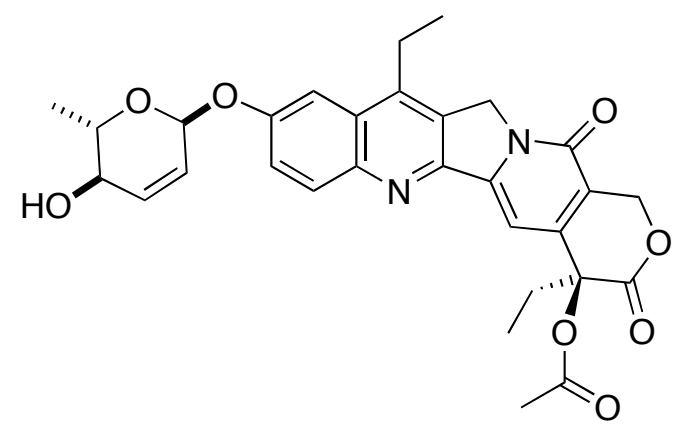

Pyranone $105(40 \mathrm{mg})$ was dissolved in $2 \mathrm{~mL} \mathrm{CH}_{2} \mathrm{Cl}_{2}$, resulting solution was cooled to $-78^{\circ} \mathrm{C}, 2$ $\mathrm{mL}$ of $0.4 \mathrm{M} \mathrm{CeCl}_{3}$ in methanol solution was added in a dropwise fashion, followed by adding $10 \mathrm{mg}$ of $\mathrm{NaBH}_{4}$. By TLC tracking, the reaction was done after $1.5 \mathrm{~h}$. The reaction mixture was diluted with $2 \mathrm{~mL}$ diethyl ether, quenched with $2 \mathrm{~mL}$ water, extracted with $3 \times 20 \mathrm{~mL}$ diethyl ether, dried over anhydrous sodium sulfate, and concentrated under reduced pressure. The crude product was purified using silica gel flash chromatography eluting with $80 \% \mathrm{EtOAc} / \mathrm{Hexane}$. At this stage only a crude ${ }^{1} \mathrm{H}$ NMR was taken.

Alternatively:

$\mathrm{A} \mathrm{CH}_{2} \mathrm{Cl}_{2}(5 \mathrm{~mL})$ solution of compound $102(43 \mathrm{mg}, 0.1 \mathrm{mmol})$ and compound 106 (35 mg, 0.15 mmol) was cooled to $0{ }^{\circ} \mathrm{C}$. A $\mathrm{CH}_{2} \mathrm{Cl}_{2}(1 \mathrm{~mL})$ solution of $\mathrm{Pd}_{2}(\mathrm{DBA})_{3} \cdot \mathrm{CHCl}_{3}(3 \mathrm{mg}, 2.5 \mathrm{~mol} \%)$ and $\mathrm{PPh}_{3}(4 \mathrm{mg}, 10 \mathrm{~mol} \%)$ was added to the reaction mixture at $0{ }^{\circ} \mathrm{C}$. The reaction mixture was stirred at $0{ }^{\circ} \mathrm{C}$ for $2 \mathrm{~h}$. The reaction mixture was quenched with $5 \mathrm{~mL}$ of saturated aq $\mathrm{NaHCO}_{3}$, extracted with $\mathrm{CH}_{2} \mathrm{Cl}_{2}$, dried $\left(\mathrm{Na}_{2} \mathrm{SO}_{4}\right)$, and concentrated under reduced pressure. The crude product was purified using silica gel flash chromatography eluting with $\mathrm{CHCl}_{3} / \mathrm{MeOH}=$ 
80:1 50:1 to give $44 \mathrm{mg}(83 \%)$ of compound 107 as an oil. $R_{f}(50 \% \mathrm{MeOH} / \mathrm{EtOAc})=0.20$; $[\alpha]_{\mathrm{D}}^{21}=-50\left(c=0.1, \mathrm{CD}_{3} \mathrm{OD}\right)$; IR (thin film, $\left.\mathrm{cm}^{-1}\right) 3411,3050,2933,1740,1612,1513,1245$, 1161, 1032, 997, 819; ${ }^{1} \mathrm{H}$ NMR $\left(600 \mathrm{MHz}, \mathrm{CD}_{3} \mathrm{OD}\right) \delta 8.05(\mathrm{~d}, J=9.0,1 \mathrm{H}), 7.75(\mathrm{~d}, J=2.4 \mathrm{~Hz}$, 1H), 7,56 (dd, $J=9.0,2.4 \mathrm{~Hz}, 1 \mathrm{H}), 7.30(\mathrm{~s}, 1 \mathrm{H}), 5.67(\mathrm{~d}, J=1.2 \mathrm{~Hz}, 1 \mathrm{H}), 5.56(\mathrm{~d}, J=16.5 \mathrm{~Hz}$, $1 \mathrm{H}), 5.45(\mathrm{~d}, J=16.5 \mathrm{~Hz}, 1 \mathrm{H}), 5.21(\mathrm{~d}, J=18.0 \mathrm{~Hz}, 1 \mathrm{H}), 5.18(\mathrm{~d}, J=18.0 \mathrm{~Hz}, 1 \mathrm{H}), 4.12(\mathrm{dd}, J=$ 3.0, $1.8 \mathrm{~Hz}, 1 \mathrm{H}), 3.92(\mathrm{dd}, J=9.0,3.6 \mathrm{~Hz}, 1 \mathrm{H}) 3.70(\mathrm{dd}, J=4.2,4.2 \mathrm{~Hz}, 1 \mathrm{H}), 3.65(\mathrm{~m}, 1 \mathrm{H}), 3.51$ (m, 2H), 3.2-3.1 (m, 4H), 2.24 (s, 3H), 1.37 (dd, $J=7.8,7.8 \mathrm{~Hz}, 3 \mathrm{H}), 1.24(\mathrm{~d}, J=6.6 \mathrm{~Hz}, 3 \mathrm{H})$, $1.04(\mathrm{dd}, J=7.5,7.5 \mathrm{~Hz}, 3 \mathrm{H}) ;{ }^{13} \mathrm{C} \mathrm{NMR}\left(150 \mathrm{MHz}, \mathrm{CD}_{3} \mathrm{OD}\right) \delta 171.6,169.7,159.1,157.0,151.3$, $148.6,148.3,146.7,146.4,132.3,129,6,129.4,124.4,120.2,107.9,100.3,97.5,77.7,73.9,72.4$ 72.1, 67.9, 66.6, 50.9, 30.8, 24.1, 20.7, 18.3, 14.1, 8.2; CIHRMS Calcd for $\left[\mathrm{C}_{30} \mathrm{H}_{32} \mathrm{~N}_{2} \mathrm{O}_{10} \mathrm{Na}\right]^{+}$: 603.1955, Found 603.1961. 


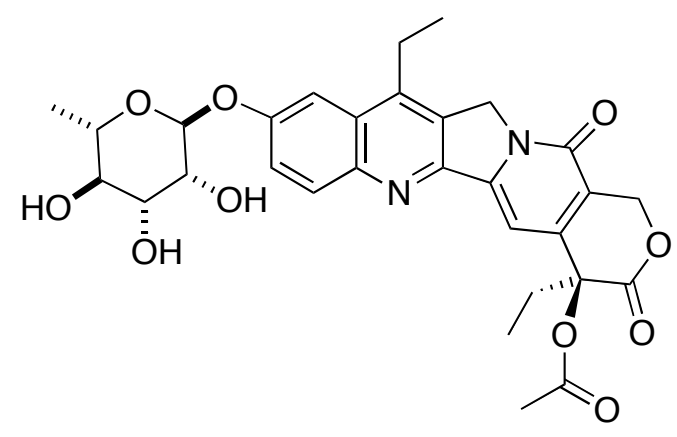

To a $t$-butanol/acetone $(4.3 \mathrm{ml}, 1: 1)$ solution of pyran $107(20 \mathrm{mg}, 4.3 \mathrm{mmol})$ at $0{ }^{\circ} \mathrm{C}$ was added a solution of $(50 \% \mathrm{w} / \mathrm{v})$ of $\mathrm{N}$-methyl morpholine $\mathrm{N}$-oxide / water $(4.3 \mathrm{~mL})$. Crystalline $\mathrm{OsO}_{4}$ $(1.1 \mathrm{mg}, 1 \mathrm{~mol} \%)$ was added and the reaction was stirred for $12 \mathrm{~h}$. The reaction was quenched by adding EtOAc and satd. aq. $\mathrm{NaHCO}_{3}$. The organic layer was separated and concentrated. The crude product was purified using silica gel flash chromatography eluting with 50\% EtOAc/hexanes to give triol $\mathbf{1 0 8}(21 \mathrm{mg}, 85 \%)$ as a colorless oil. $R_{f}(50 \% \mathrm{MeOH} / \mathrm{EtOAc})=0.20$; $[\alpha]_{\mathrm{D}}^{21}=-50\left(c=0.1, \mathrm{CD}_{3} \mathrm{OD}\right)$; IR (thin film, $\left.\mathrm{cm}^{-1}\right) 3411,3050,2933,1740,1612,1513,1245$ 1161, 1032, 997, 819; ${ }^{1} \mathrm{H}$ NMR (600 MHz, $\left.\mathrm{CD}_{3} \mathrm{OD}\right) \delta 8.05(\mathrm{~d}, J=9.0,1 \mathrm{H}), 7.75(\mathrm{~d}, J=2.4 \mathrm{~Hz}$, 1H), 7,56 (dd, $J=9.0,2.4 \mathrm{~Hz}, 1 \mathrm{H}), 7.30(\mathrm{~s}, 1 \mathrm{H}), 5.67$ (d, $J=1.2 \mathrm{~Hz}, 1 \mathrm{H}), 5.56(\mathrm{~d}, J=16.5 \mathrm{~Hz}$, $1 \mathrm{H}), 5.45(\mathrm{~d}, J=16.5 \mathrm{~Hz}, 1 \mathrm{H}), 5.21(\mathrm{~d}, J=18.0 \mathrm{~Hz}, 1 \mathrm{H}), 5.18(\mathrm{~d}, J=18.0 \mathrm{~Hz}, 1 \mathrm{H}), 4.12(\mathrm{dd}, J=$ $3.0,1.8 \mathrm{~Hz}, 1 \mathrm{H}), 3.92(\mathrm{dd}, J=9.0,3.6 \mathrm{~Hz}, 1 \mathrm{H}) 3.70(\mathrm{dd}, J=4.2,4.2 \mathrm{~Hz}, 1 \mathrm{H}), 3.65(\mathrm{~m}, 1 \mathrm{H}), 3.51$ $(\mathrm{m}, 2 \mathrm{H}), 3.2-3.1(\mathrm{~m}, 4 \mathrm{H}), 2.24(\mathrm{~s}, 3 \mathrm{H}), 1.37(\mathrm{dd}, J=7.8,7.8 \mathrm{~Hz}, 3 \mathrm{H}), 1.24(\mathrm{~d}, J=6.6 \mathrm{~Hz}, 3 \mathrm{H})$, $1.04(\mathrm{dd}, J=7.5,7.5 \mathrm{~Hz}, 3 \mathrm{H}) ;{ }^{13} \mathrm{C} \mathrm{NMR}\left(150 \mathrm{MHz}, \mathrm{CD}_{3} \mathrm{OD}\right) \delta 171.6,169.7,159.1,157.0,151.3$, $148.6,148.3,146.7,146.4,132.3,129,6,129.4,124.4,120.2,107.9,100.3,97.5,77.7,73.9,72.4$, 
72.1, 67.9, 66.6, 50.9, 30.8, 24.1, 20.7, 18.3, 14.1, 8.2; CIHRMS Calcd for $\left[\mathrm{C}_{30} \mathrm{H}_{32} \mathrm{~N}_{2} \mathrm{O}_{10} \mathrm{Na}\right]^{+}$: 603.1955, Found 603.1961. 


\section{References and Notes:}

${ }^{1}$ Yu, X.; O'Doherty, G. A. Org. Lett. 2008, 10, 4529-4532.

2 Thomas, R. ChemBioChem 2001, 2, 612-627.

${ }^{3}$ (a) Rohr, J.; Thiericke, R. Nat. Prod. Rep. 1992, 9, 103-137. (b) Krohn, K.; Rohr, J. Top. Curr. Chem. 1997, 188, 127-195. (c) Andriy, L.; Andreas, V.; Andreas, B. Mol. BioSyst. 2005, 1, 117-126.

${ }^{4}$ Kirschning, A.; Bechtold, A. F.-W.; Rohr, J. Chemical and Biochemical acpects of deosxy sugars and deoxysugar oligosaccharides, in Topics in Current chemistry, 1997, 188, 1-84.

${ }^{5}$ For Studies toward the synthesis of angularly-oxygenated angucyclines antibiotic WP-3688-2 and SS-22BY, see: Lebrasseur, N.; Fan, G.-J.; Quideau, S. Arkivoc. 2004, 8, 5-16.

${ }^{6}$ For the synthesis of Vineomycin $B_{2}$ Aglycon, see: Danishefsky, D. J.; Uang, B. J.; Quallich, G. J. Am. Chem. Soc. 1985, 107, 1285-1293.;

${ }^{7}$ For the Synthetic study of Aquayamycin, see: Matsumoto, T.; Yamaguchi, H.; Hamura, T.; Tanabe, M.; Kuriyama, M.;Suzuki, K. Tetrahedron lett. 2000, 41, 8383-8387.

${ }^{8}$ Urdamycinone B synthesis, see: (a) Boyd, V. A.; Sulikowski, G. A. J. Am. Chem. Soc. 1995, 117, 8472-8473; (b) Total synthesis of urdamycinone B via C-glycosidation of an unprotected sugar and Diels-Alder reaction of C-glycosyl juglone. Matsuo, G.; Miki, Y.; Nakata, M.; Matsumura, S.; Toshima, K. Chem. Commun. 1996, 225-226. 
${ }^{9}$ For synthetic efforts to vineomycin $\mathrm{B}_{2}$, see: Sasaki, K.; Matsumura, S.; Toshima, K.

Tetrahedron lett. 2007, 48, 6982-6986. For its isolation activity, see: (b) New Antitumor Antibiotics, OS-4742 $\mathrm{A}_{1}, \mathrm{~A}_{2}, \mathrm{~B}_{1}$ and $\mathrm{B}_{2}$ Produced by a Strain of Streptomyces. Omura, S.;

Tanaka, H.; Oiwa, R.; Awaya, J.; Masuma, R.; Tanaka, K. J. Antibiot. 1977, 30, 908-916; (c)

The Structure of Vineomycin B 2 Imamura, N.; Kakinuma, N.; Ikekawa, H.; Tanaka, H.;

Omura, S. J. Antibiot. 1981, 34, 1517-1518; (d) Biosynthesis of Vineomycins $\mathrm{A}_{1}$ and $\mathrm{B}_{2}$.

Imamura, N.; Kakinuma, K.; Ikekawa, N. J. Antibiot. 1982, 35, 602-608.

${ }^{10}$ For PI-080, anticoagulant activity, see: (a) New Platelet Aggregation Inhibitors. Kawashima,

A.; Kishimura, Y.; Tamai, M.; Hanada, K. Chem. Pharm. Bull. 1989, 37, 3429-3431; (b)

Application of Glycosyltetrazoles in Oligosaccharide Synthesis: Assembly of the C3

Trisaccharide Component of the Antibiotic PI-080.Sobti, A.; Kim, K.; Sulikowski, G. A. J.

Org. Chem. 1996, 61, 6-7..

${ }^{11}$ For the isolation of vineomycin C, see: (a) Omura, S.; Tanaka, H.; Oiwa, R.; Awaya, L.;

Masuma, R.; Tanaka, K. J. Antibiot. 1977, 30, 908-916. (b) Imamura, N.; Nakinuma, K.;

Ikekawa, N.; Tanaka, H.; Omura, S. J. Antibiot. 1981, 34, 1517-1518.

${ }^{12}$ Two natural products have been isolated with the same structure as PI-080. For PI-080, see:

(a) Kawashima, A.; Kishimura, Y.; Tamai, M.; Hanada, K. Chem. Pharm. Bull. 1989, 37,

3429-3431. For PI-6621, see: (b) Kawashima, A.; Yoshimura, Y.; Kamigori, K.; Yagishi, M.;

Mizutani, T. Chem. Abstr. 1989, 114, $22464 d$.

${ }^{13}$ Both vineomycin $\mathrm{C}$ and the related monosaccharide angucycline, vineomycinone B2 (2 sans aL-aculose-a-L-rhodinose), possess antitumor activity against S-180 solid tumors in mice; 
thus, associating the antitumor activity with the common anthraquinone portion of the molecules, see: ref. 3 .

${ }^{14}$ For the synthesis of vineomycinone B2, see: (a) Danishefsky, S. J. Uang, B. J. Quallich, G. J. Am. Chem. Soc. 1985, 107, 1285-1293. (b) Bolitt, V.; Mioskowski, C.; Kollah, R. O.; Manna, S.; Rajapaksa, D. Falck, J. R. J. Am. Chem. Soc. 1991, 113, 6320-6321. (c) Tius, M. A.; Gomez-Galeno, J.; Gu, X.-q; Zaidi, J. H. J. Am. Chem. Soc. 1991, 113, 5775-5783. (d) Matsumoto, T.; Katsuki, M.; Jona, H.; Suzuki, K. J. Am. Chem. Soc. 1991, 113, 6982-6992. (b) Chen, C.-L.; Sparks, S. M.; Martin, S. F. J. Am. Chem. Soc. 2006, 128, 13696-13697.

15 (a) Sobti, A.; Kyungjin Kim, K.; Sulikowski, G. A. J. Org. Chem. 1996, 61, 6-7. For related approaches, see: (b) Sasaki, K.; Matsumura, S.; Toshima, K. Tetrahedron Lett. 2007, 48, 6982-6986.

${ }^{16}$ Zhou, M.; O’Doherty, G. A. Org. Lett. 2008, 10, 2283-2286.

${ }^{17}$ Fujii, A.; Hashiguchi, S.; Uematsu, N.; Ikariya, T.; Noyori, R. J. Am. Chem. Soc. 1996, 118 , $2521-2522$.

${ }^{18}$ (a) Li, M.; Scott, J. G.; O'Doherty, G. A. Tetrahedron Lett. 2004, 45, 1005-1009. (b) Li, M.; O'Doherty, G. A. Tetrahedron Lett. 2004, 45, 6407-6411.

${ }^{19}$ (a) Babu, R. S.; O'Doherty, G. A. J. Carbohydr. Chem. 2005, 24, 169-177. (b) Guo, H.; O’Doherty, G. A. Org. Lett. 2005, 7, 3921-3924.

${ }^{20}$ Zhou, M.; O’Doherty, G. A. J. Org. Chem. 2007, 72, 2485-2493. 
${ }^{21}$ (a) Myers, A. G.; Zheng, B. J. Am. Chem. Soc. 1996, 118, 4492-4493. (b) Myers, A. G.; Zheng, B.; Movassaghi, M. J. Org. Chem. 1997, 62, 7507-7507. (d) Haukaas, M. H.; O’Doherty, G. A. Org. Lett. 2002, 4, 1771-1774.

${ }^{22}$ VanRheenen, V.; Kelly, R. C.; Cha, D. Y. Tetrahedron Lett. 1976, 17, 1973-1976.

${ }^{23}$ Abdelfattah, M. S.; Kharel, M. K.; Hitron, J. A.; Baig, I.; Rohr, J. J. Nat. Prod. 2008, ASAP (DOI: 10.1021/np800281f).

${ }^{24}$ (a) Chu, M.; Yarborough, R.; Schwartz, J.; Patel, M. G.; Horan, A. C.; Gullo, V. P.; Das, P. R.; Puar, M. S. J. Antibiot. 1993, 46, 861. (b) Thomson, R. H. Naturally Occurring Quinones III; Chapman and Hall: New York, 1987.

${ }^{25}$ Morton, G. E.; Barrett, A. G. M. Org. Lett. 2006, 8, 2859-2861.

${ }^{26}$ Morton, G. E.; Barrett, A. G. M. J. Org. Chem. 2005, 70, 3525.

${ }^{27}$ G. M. L. Cragg, R. G. F. Giles and G. H. P. Roos J. Chem. Soc., Perkin Trans. 1, 1975, 1339 1342.

${ }^{28}$ Ferrier, R. J.; Prasad, N. J. Chem. Soc. C 1969, 570.

29 Garbett, N.C.; Graves, D.E. Curr. Med. Chem. 2004, 4, 149.

30 O’Leary, J.; Muggia, F. M.; Eur J Cancer 1998, 34,1500-8.

${ }^{31}$ For the isolation and structural determination of ellipticine, see: Goodwin S.; Smith, A. F.; Horning, E. C. J. Am. Chem. Soc. 1959, 81, 1903-1908. 
${ }^{32}$ For the isolation and structural determination of camptothecin, see: Wall, M.E. ; Wani, M.C.; Cook, C.E. ; Palmer, K.H.; A.I.McPhail, A.I.; Sim, G.A.; J. Am. Chem. Soc. 1966, 88, 38883890

${ }^{33}$ Dalton, L. K.; Demerac, S.; Elmes, B. C.; Loder, J. W.; Swan, J. M.; Teitei, T. Aust. J. Chem. 1967, 20, 2715-2727.

${ }^{34}$ (a) Sharaf, M. H. M.; Schiff, P. L., Jr.; Tackie, A. N.; Phoebe, C.H., Jr.; Martin, G. E. J. Heterocycl. Chem. 1996, 33, 239-243. (b) Cimanga, K.; De Bruyne, T.; Pieters, L.; Claeys, M.; Vlietinck, A.

Tetrahedron Lett. 1996, 37, 1703-1706.

${ }^{35}$ For synthetic approaches to ellipticine, see: (a) Gribble, G. W. In The Alkaloids; Brossi, A., Ed.; Academic Press: New York, 1990; Vol. 39, p 239. (b) Suffness, M.; Cordell, G. A. In The Alkaloids; Brossi, A., Ed.; Academic Press: New York, 1985; Vol. 25, pp 89, 304. (c) Kansal, V. K.; Potier, P. Tetrahedron 1986, 42, 2389-2408. (d) Gribble, G. W.; Saulnier, M. G.; Obaza-Nutaitis, J. A.; Ketcha, D. M. J. Org. Chem. 1992, 57, 5891-5899. (e) Ishikura, M.; Yaginuma, T.; Agata, I.; Miwa, Y.; Yanada, R.; Taga, T. Synlett 1997, 214-216. (f) Dı'az, M. T.; Cobas, A.; Guitia'n, E.; Castedo, L. Synlett 1998, 157-158. (g) Ergün, Y.; Patir, S.; Okay, G. J. Heterocycl. Chem. 1998, 35, 1445-1447. (h) Ishikura, M.; Hino, A.; Yaginuma, T.; Agata, I.; Katagiri, N. Tetrahedron 2000, 56, 193-207. (i) Anderson, W. K.; Gopalsamy, A.; Reddy, P. S. J. Med. Chem. 1994, 37, 1955-1963.

${ }^{36}$ Cimanga, K.; De Bruyne, T.; Pieters, L.; Vlietinck, A. J.; Turger, C. A. J. Nat. Prod. 1997, 60, 
688-691.

37 Zhang, Q.; Shi, C.; Zhang, H.-R.; Wang, K. K. J. Org. Chem. 2000, 65, 7977-7983

38 (a) Shi, C.; Zhang, Q.; Wang, K. K. J. Org. Chem. 1999, 64, 925-932.

39 a) Schmittel, M.; Strittmatter, M.; Vollmann, K.; Kiau, S. Tetrahedron Lett. 1996, 37, 999-1002. b) Schmittel, M.; Strittmatter, M.; Kiau, S. Angew. Chem., Int. Ed. Engl. 1996, 35, 1843-1845. c) Schmittel, M.; Keller, M.; Kiau, S.; Strittmatter, M. Chem. Eur. J. 1997, 3, 807-816. d) Schmittel, M.; Vavilala, C. J. Org. Chem. 2005, 70, 4865-4868.

${ }^{40}$ (a) Hill, P. L.; Yap, G. P. A.; Rheingold, A. L.; Maatta, E. A. J. Chem. Soc., Chem. Commun. 1995, 737-738.

41 For a good review, see: Wu Du Tetrahedron 2003, 59, 8649-8687.

42 (a) Wall, M. E.; Wani, M. C.; Cook, C. E.; Palmer, K. H.; McPhail, A. T.; Sim, G. A. J. Am. Chem. Soc. 1966, 88, 3888. (b) Wall, M. E. Med. Res. Rev. 1998, 18, 299.

43 For successful syntheses of camptothecin, see: (a) Curran, D. P.; Ko, S. B.; Josien, H. Angew. Chem., Int. Ed. Engl. 1996, 34, 2683. (b) Comins, D. L.; Hong, H.; Jianhua, G. Tetrahedron Lett. 1994, 35, 5331. (c) Tang, C.; Rapoport, H. J. Am. Chem. Soc. 1972, 94, 8615.

${ }^{44}$ C. J. Thomas, N. J. Rahier, Si. M. Hecht Bioorganic \& Medicinal Chemistry 12 (2004) 15851604

${ }^{45}$ M. R. Redinbo, L. Stewart, P. Kuhn, J. J. Champoux, W. G. J. Hol Science 1998, 279, 15041513. 
46 DNA Topoisomerases in Cancer; Potmesil, M., Kohn, K. W.,Eds.; Oxford University: New York, 1991.

47 Camptothecins: New Anticancer Agents; Potmesil, M., Pinedo, H., Eds.; CRC: Boca Raton, 1995.

48 a) Ormrod, D.; Spencer, C. M. Drugs 1999, 58, 533. b) Herzog, T. J. Oncologist 2002, 7(Suppl. 5), 3. c) Saltz, L. B. Colorectal Cancer; Saltz, L. B., Ed.; Humana Press Inc., Totowa, 2002, 513.

${ }^{49}$ A. J. Lu, Z. S. Zheng, H. J. Zou, X. M. Luo, H. L. Jiang European Journal of Medicinal Chemistry 2007 42, 307-314.

50 For the Wang approach to the camptothecins, see: Dai, W.; Petersen, J. L.; Wang, K. K. Org. Lett. 2006, 8, 4665-4667.

51 For the other approach to the camptothecins, see: a) Liu, H.; Ko, S.-B.; Josien, H.; Curran, D. P. Tetrahedron Lett. 1995, 36, 8917-8920. b) Kametani, T.; Nemoto, H.; Takeda, H.; Takano, S. Tetrahedron 1970, 26, 5753-5755. c) Curran, D. P.; Liu, H., J. Am. Chem. Soc. 1992, 114, 5863-5864. d) Nguyen, T.; Wicki, M. A.; Snieckus, V. J. Org. Chem. 2004, 69, 7816-7821.

${ }^{52}$ Murata, T.; Nizuma, S.; Shimma, N.; Suda, H.; Tsukazaki, M. U.S. Patent 6,825,194.

${ }^{53}$ N. Ravindranath, C. Ramesh, M. Ravinder Reddy, K. V. N. S. Srinivas, and Biswanath Das, Synthetic Commun. 2003, 33, 4029-4035.

${ }^{54}$ Wu Du, Bashir Kaskar, Peter Blumbergs, P.-K. Subramanian, D. P. Curran Bioorganic \& 
Medicinal Chemistry 2003, 11, 451-458.

${ }^{55}$ Luo, Y.; Gao, H.; Li, Y.; Huang, W.; Lu, W.; Zhang, Z. Tetrahedron 2006, 62, 2465-2470.

${ }^{56}$ Gelman, D.; Buchwald, S. L. Angew. Chem., Int. Ed. 2003, 42, 5993-5996. 
Appendix: Spectra Graphs 
(R)-1-(furan-2-yl) ethanol $(7(R))$

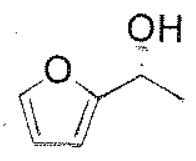

${ }^{1} \mathrm{H}$ NMR (CDCl, $\left.600 \mathrm{MHz}\right)$

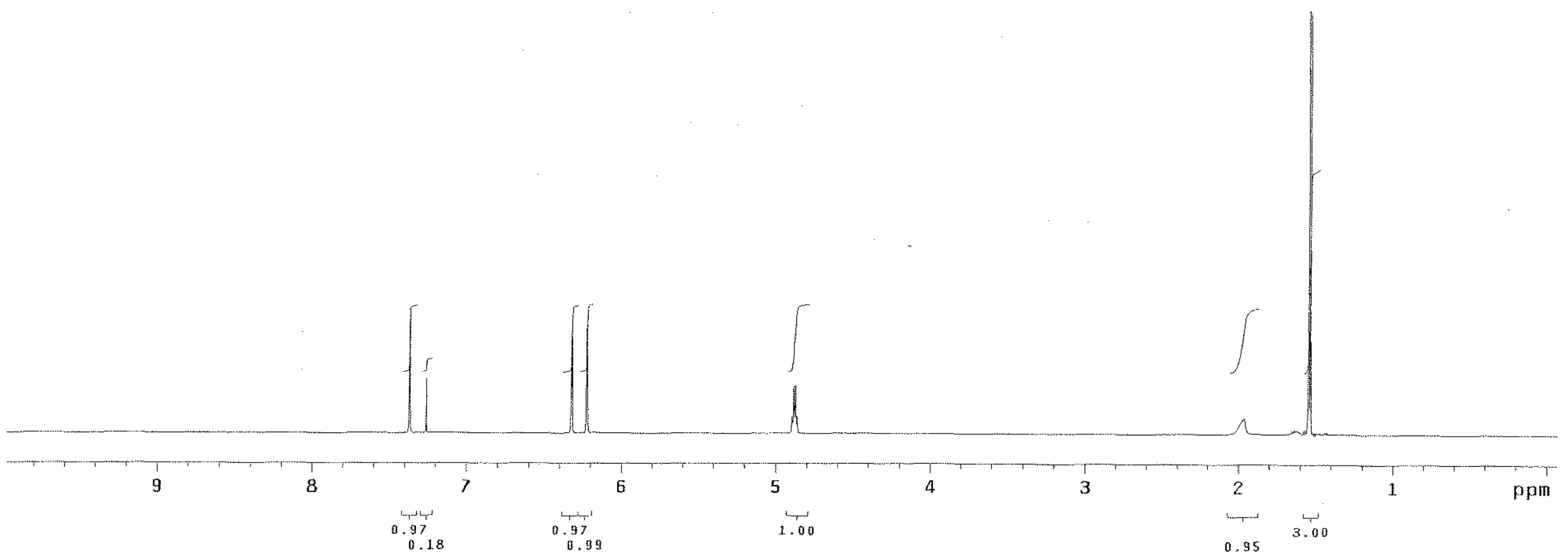


(R)-1-(furan-2-yl) ethanol $(7(R))$

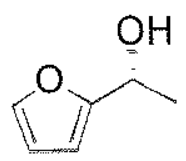

${ }^{13} \mathrm{C}$ NMR $\left(\mathrm{CDCl}_{3}, 150 \mathrm{MHz}\right)$

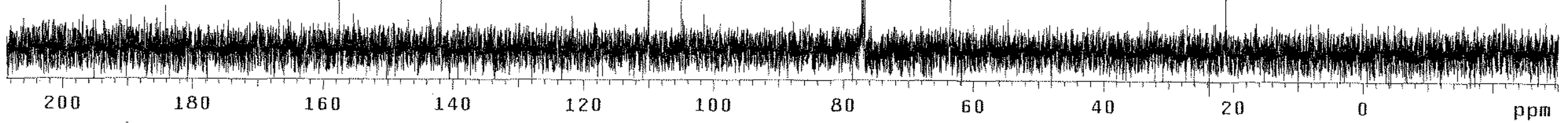


(S)-1-(2-Furyl)-ethanol (7(S)):
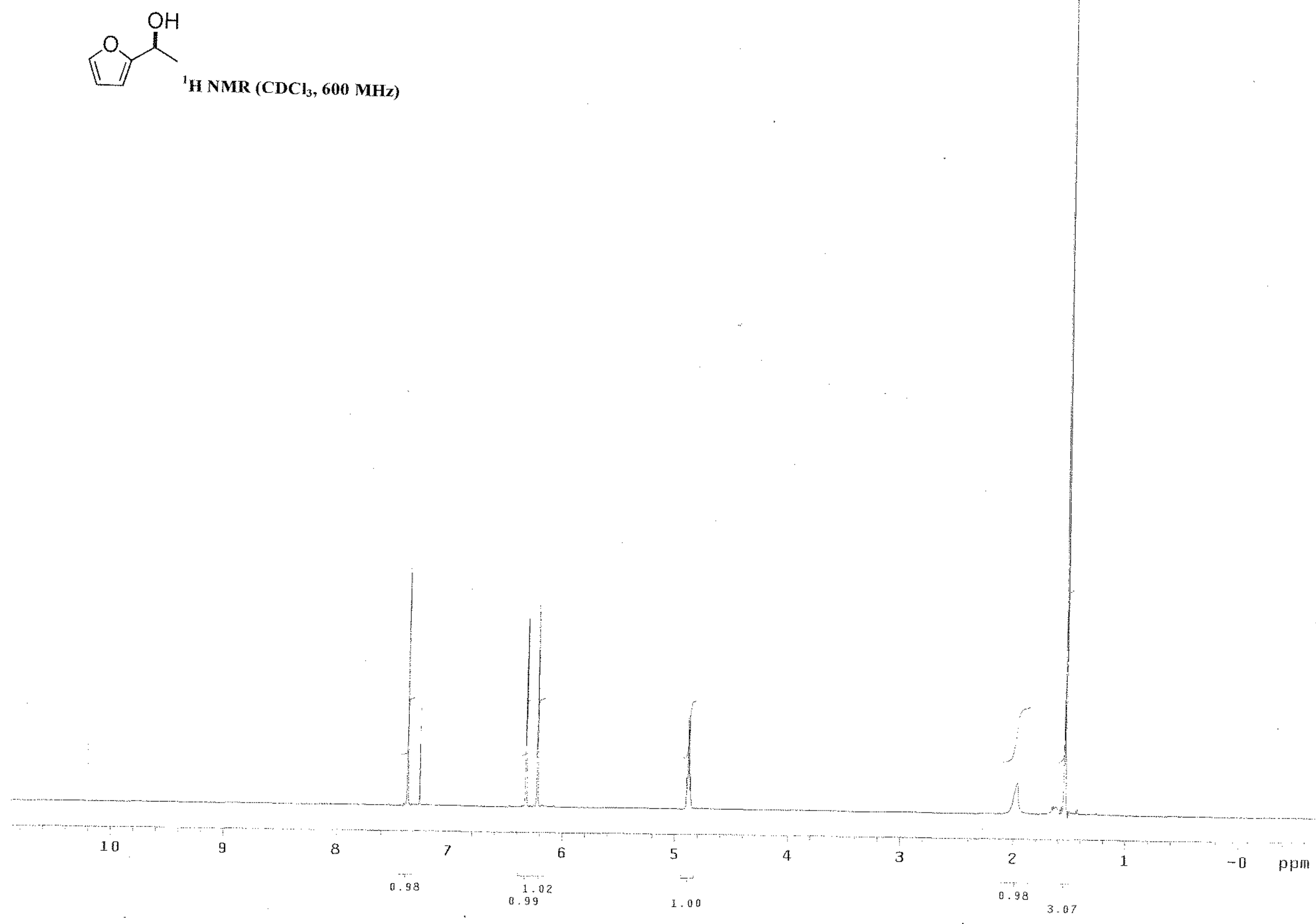
$(S)-1-(2-F u r y)$-ethanol $(7(S))$ :<smiles>CC(O)c1ccco1</smiles>

${ }^{13} \mathrm{C}$ NMR $\left(\mathrm{CDCl}_{3}, 150 \mathrm{MHz}\right)$

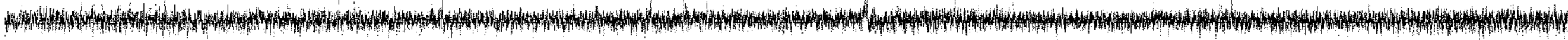


(2R)-6-Hydroxy-2- methyl-2H-Pyran-3 (6H)-one (34):<smiles>CC1O[C@H](O)C=CC1=O</smiles>

${ }^{1} \mathrm{H}$ NMR $\left(\mathrm{CDCl}_{3}, 600 \mathrm{MHz}\right)$

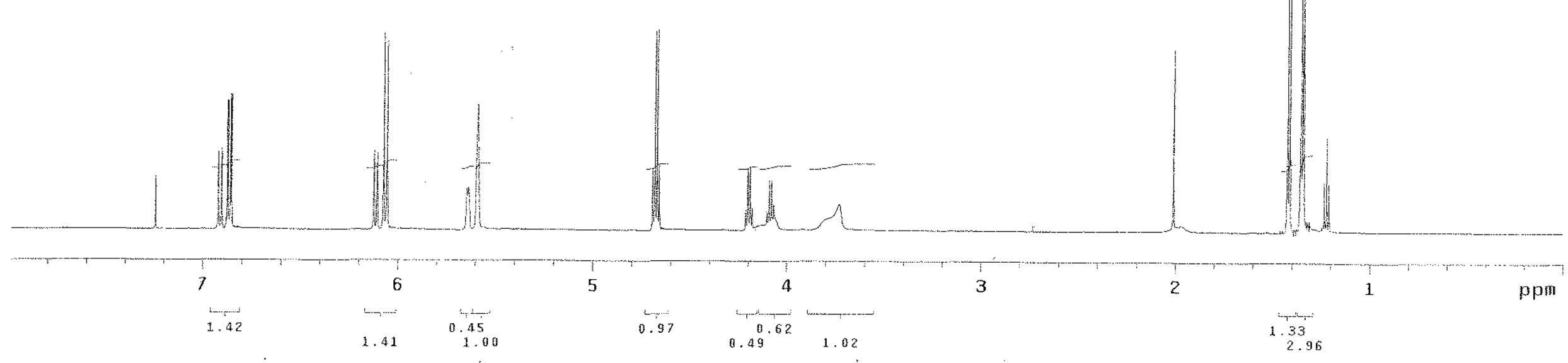


(2R)-6-Hydroxy-2- methyl-2H-Pyran-3 (6H)-one (34):<smiles>C[C@@H]1O[C@H](O)C=CC1=O</smiles>

${ }^{13} \mathrm{C} \mathrm{NMR}\left(\mathrm{CDCl}_{3}, 150 \mathrm{MHz}\right)$

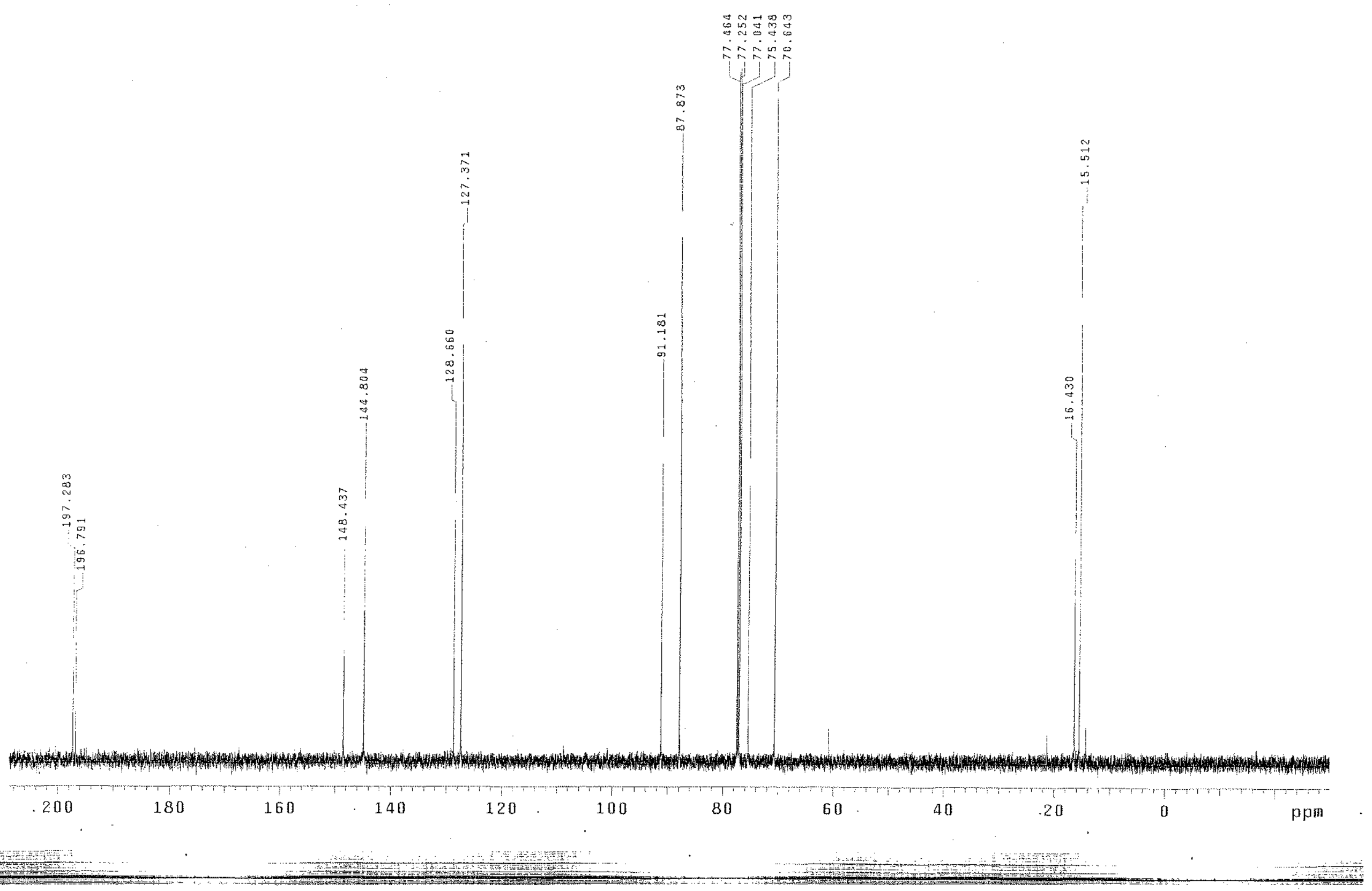




\section{$4-\rightarrow-1$}

(2S)-6-Hydroxy-2-methyl-2H-Pyran-3 (6H)-one (34):<smiles>CC1O[C@@H](O)C=CC1=O</smiles>

${ }^{1} \mathrm{H}$ NMR $\left(\mathrm{CDCl}_{3}, 600 \mathrm{MHz}\right)$

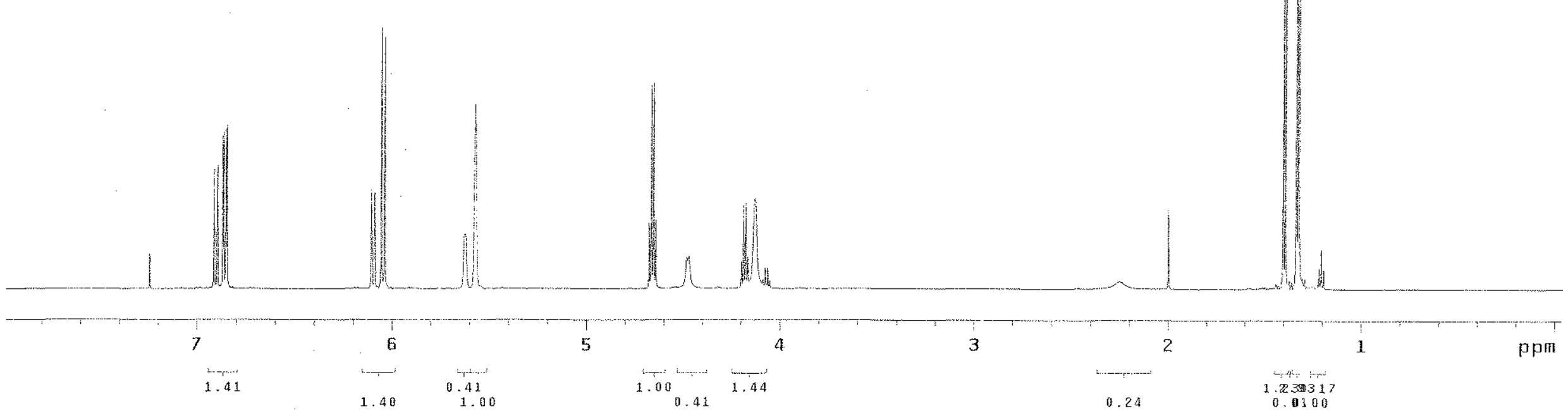




\section{(2S)-6-Hydroxy-2-methyl-2H-Pyran-3 $(6 H)$-one (34):}

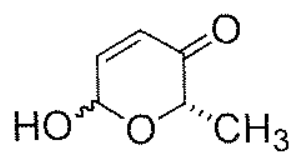

${ }^{13} \mathrm{C} \mathrm{NMR}\left(\mathrm{CDCl}_{3}, 150 \mathrm{MHz}\right)$

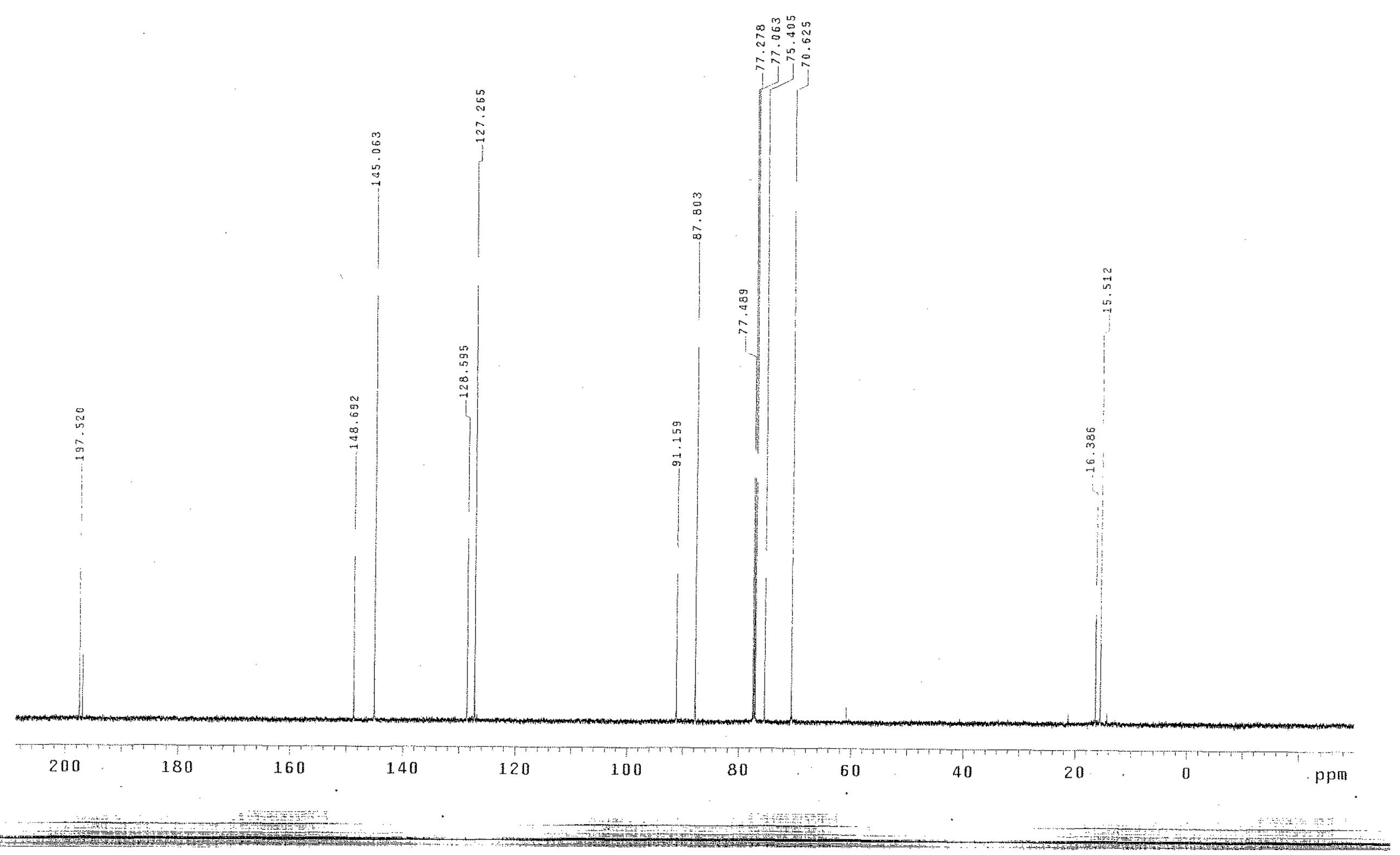


${ }^{1} \mathrm{H} \mathrm{NMR}\left(\mathrm{CDCl}_{3}, 600 \mathrm{MHz}\right)$

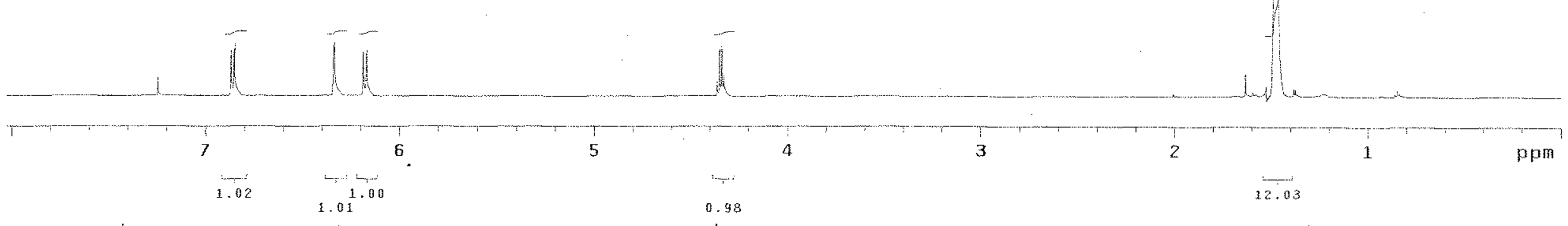


Tert-butyl $(2 R, 6 R)-5,6$-dihydro-6-methyl-5-oxo-2H-pyran-2-yl carbonate $(6(\beta-D))$
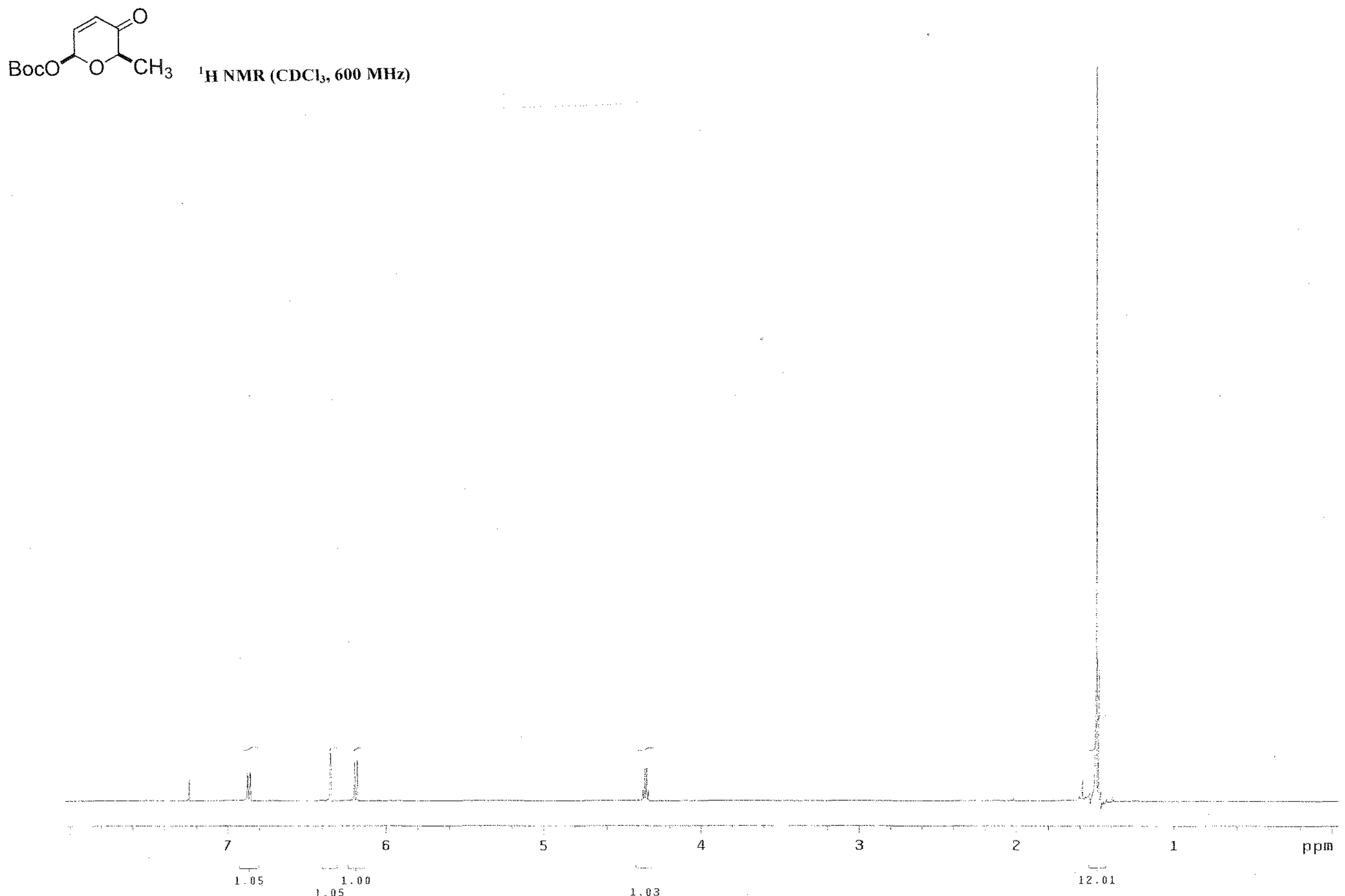
$Y:-n-m$

Tert-butyl $(2 R, 6 R)$-5,6-dihydro-6-methyl-5-oxo-2H-pyran-2-yl carbonate (6( $\beta-D))$

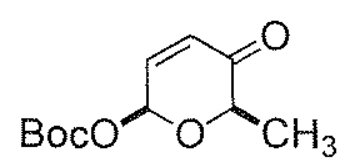

${ }^{13} \mathrm{C} \mathrm{NMR}\left(\mathrm{CDCl}_{3}, 150 \mathrm{MHz}\right)$
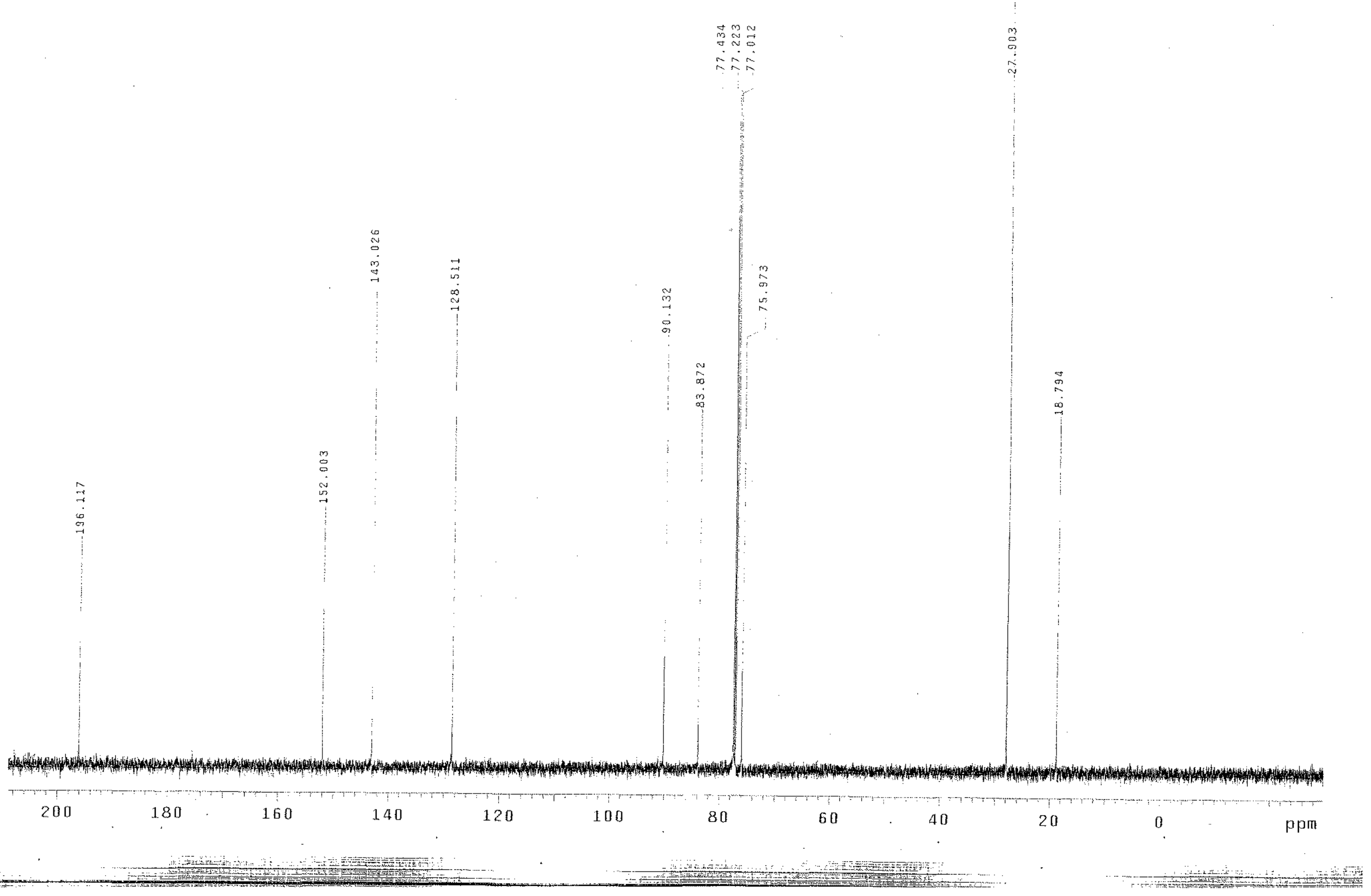
$(2 R, 6 \mathbb{R})-t$-butyl -5,6-dihydro-6-methyl-5-ox0-2H-pyran-2-yl carbon

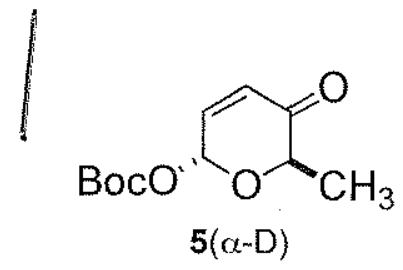

${ }^{1} \mathrm{H} \mathrm{NMR}\left(\mathrm{CDCl}_{3}, 600 \mathrm{MHz}\right)$

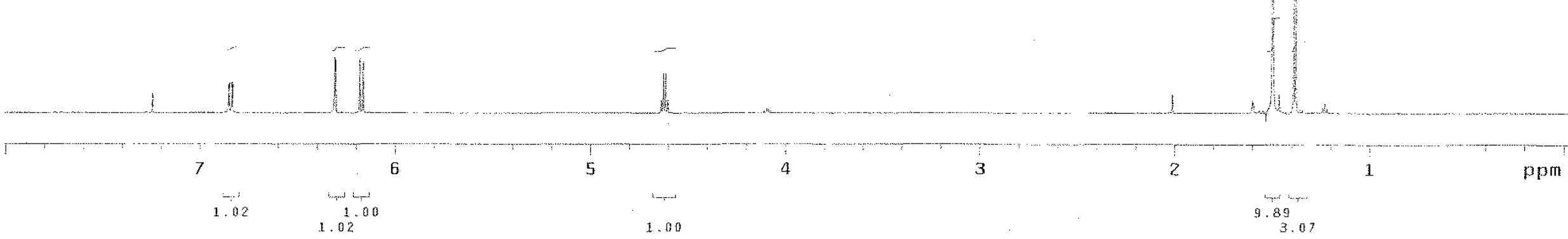


$(2 S, 6 S)-\{-b u t y l-5,6$-dihydro-6-methyl-5-oxo-2H-pyran-2-yl carbonate $(5(\alpha-L))$

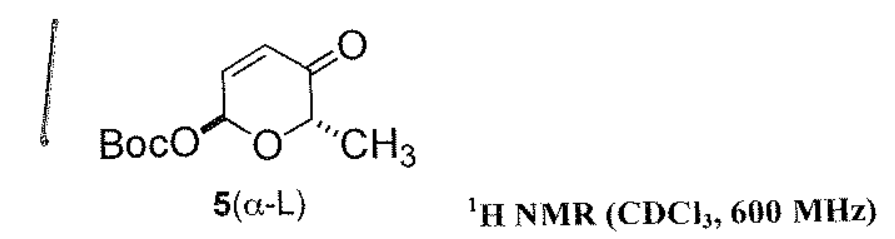

fines

H NMR $\left(\mathrm{CDCl}_{3}, 600 \mathrm{MHz}\right)$

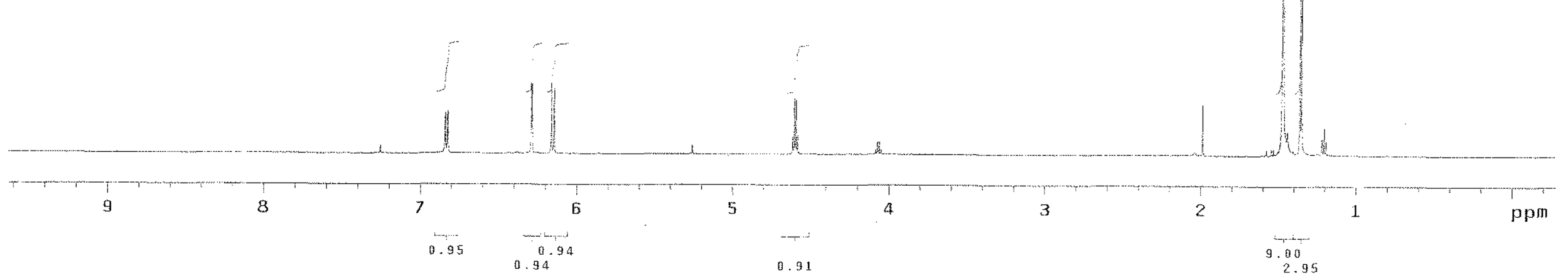


$(2 S, 6 S)-t$-butyl -5,6-dihydro-6-methyl-5-oxo-2H-pyran-2-yl carbonate $(5(\alpha-L))$

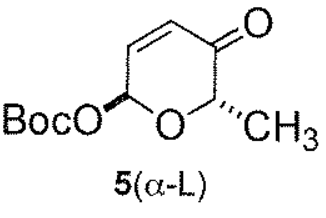

${ }^{13} \mathrm{C} \mathrm{NMR}\left(\mathrm{CDCl}_{3}, 150 \mathrm{MHz}\right)$

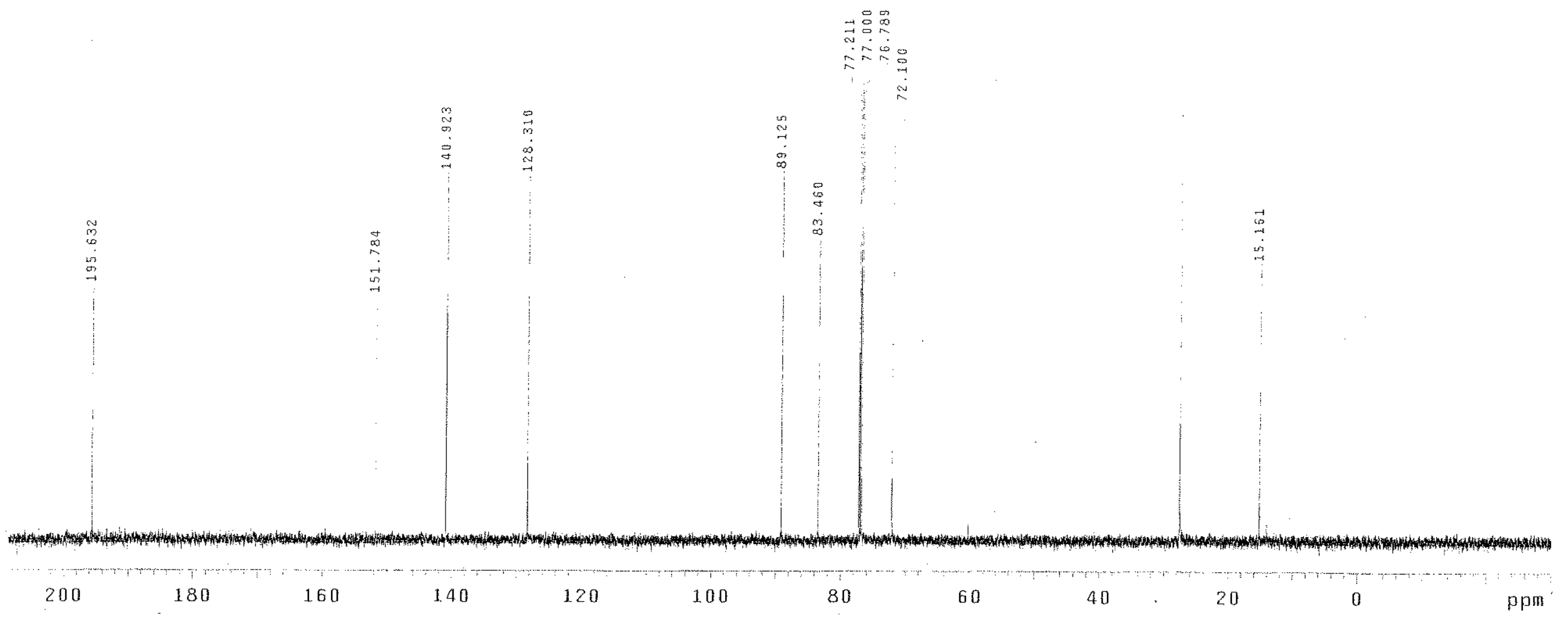


$(2 R, 6 R)-6-(4-m e t h o x y b e n z y l o x y)-2-m e t h y l-2 H-p y r a n-3(6 H)$-one $(9)$ :
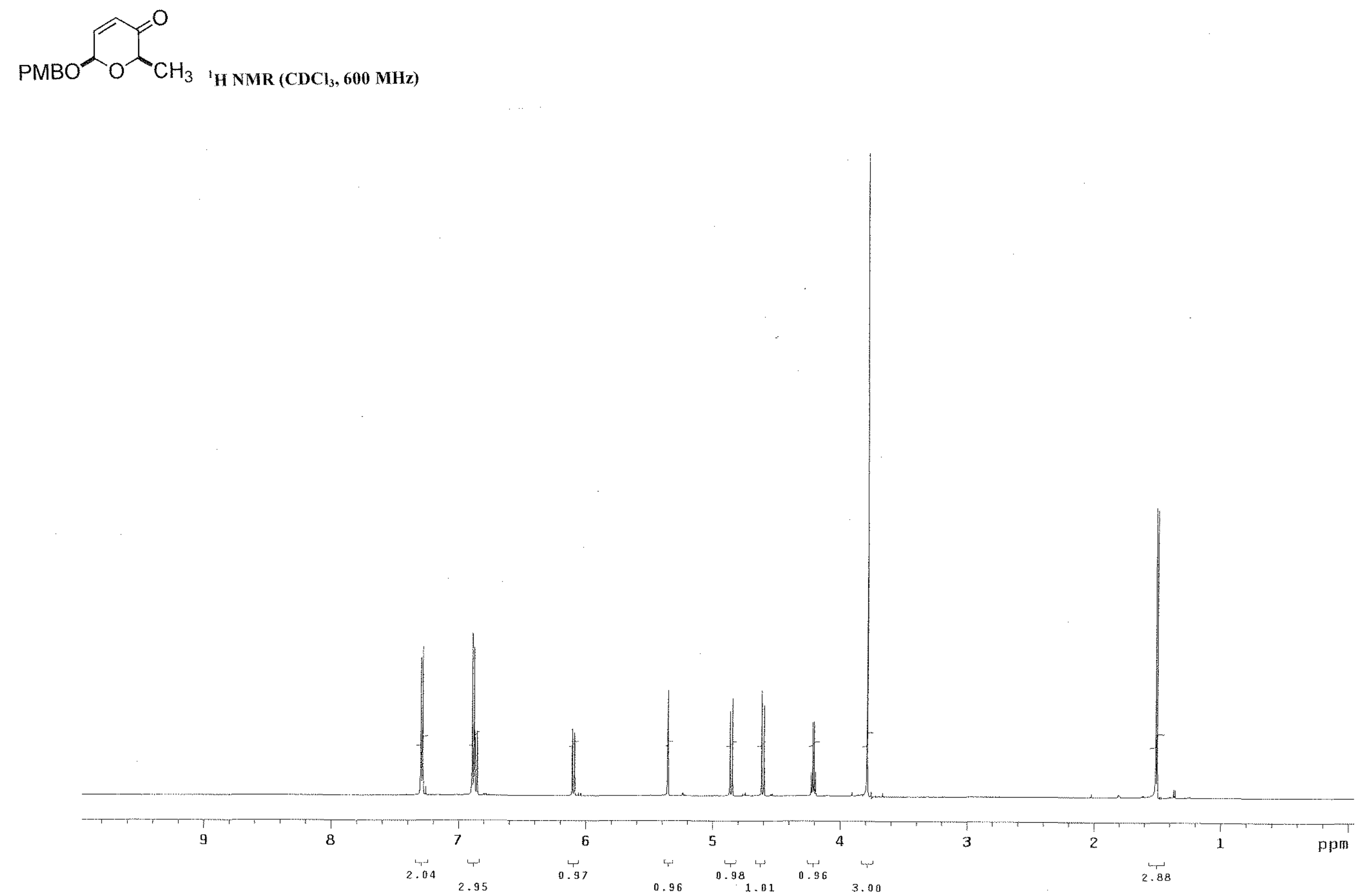
$(2 R, 6 R)-6-(4-m e t h o x y b e n z y l o x y)-2-m e t h y l-2 H$-pyran-3(6H)-one $(9)$ :
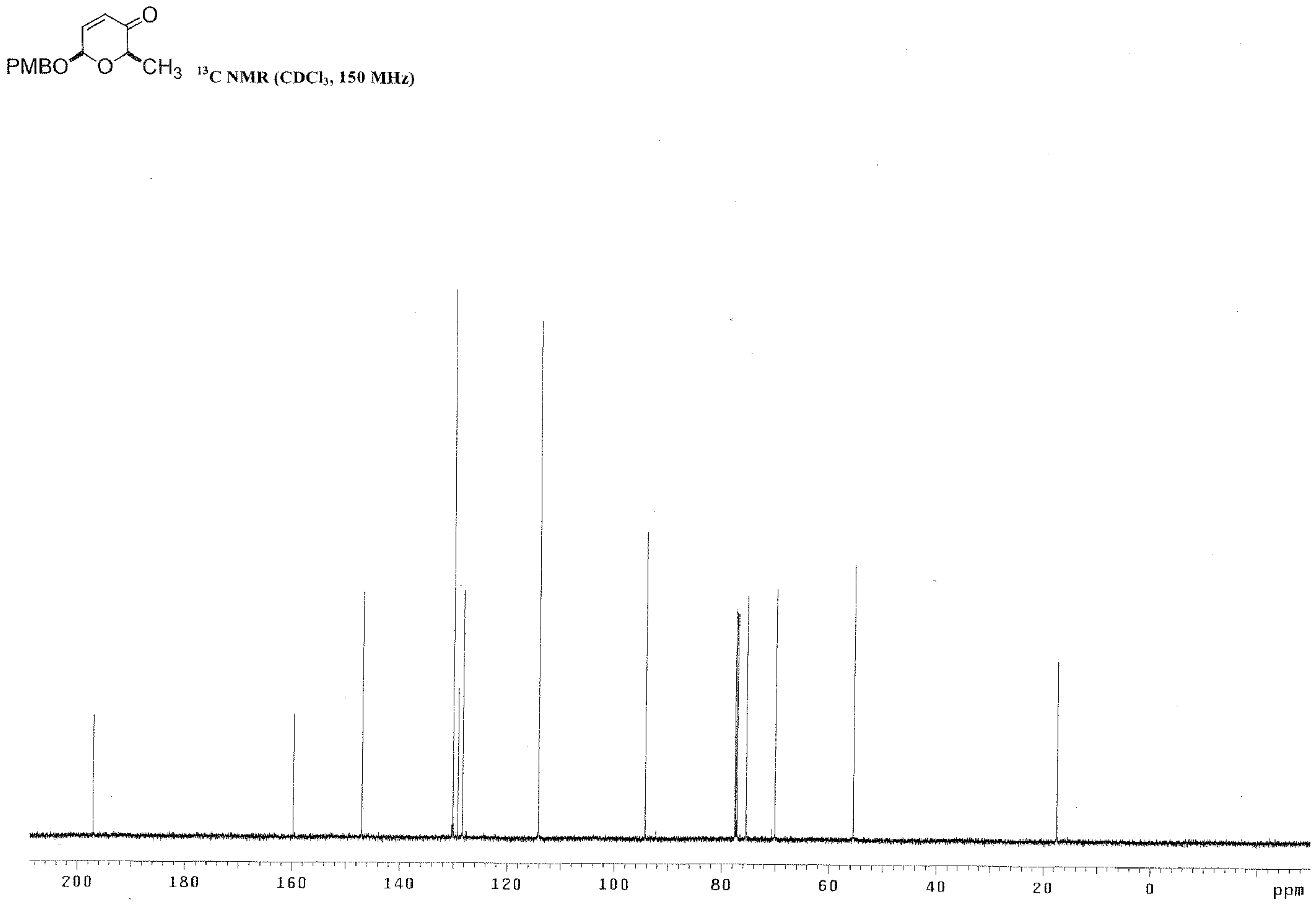

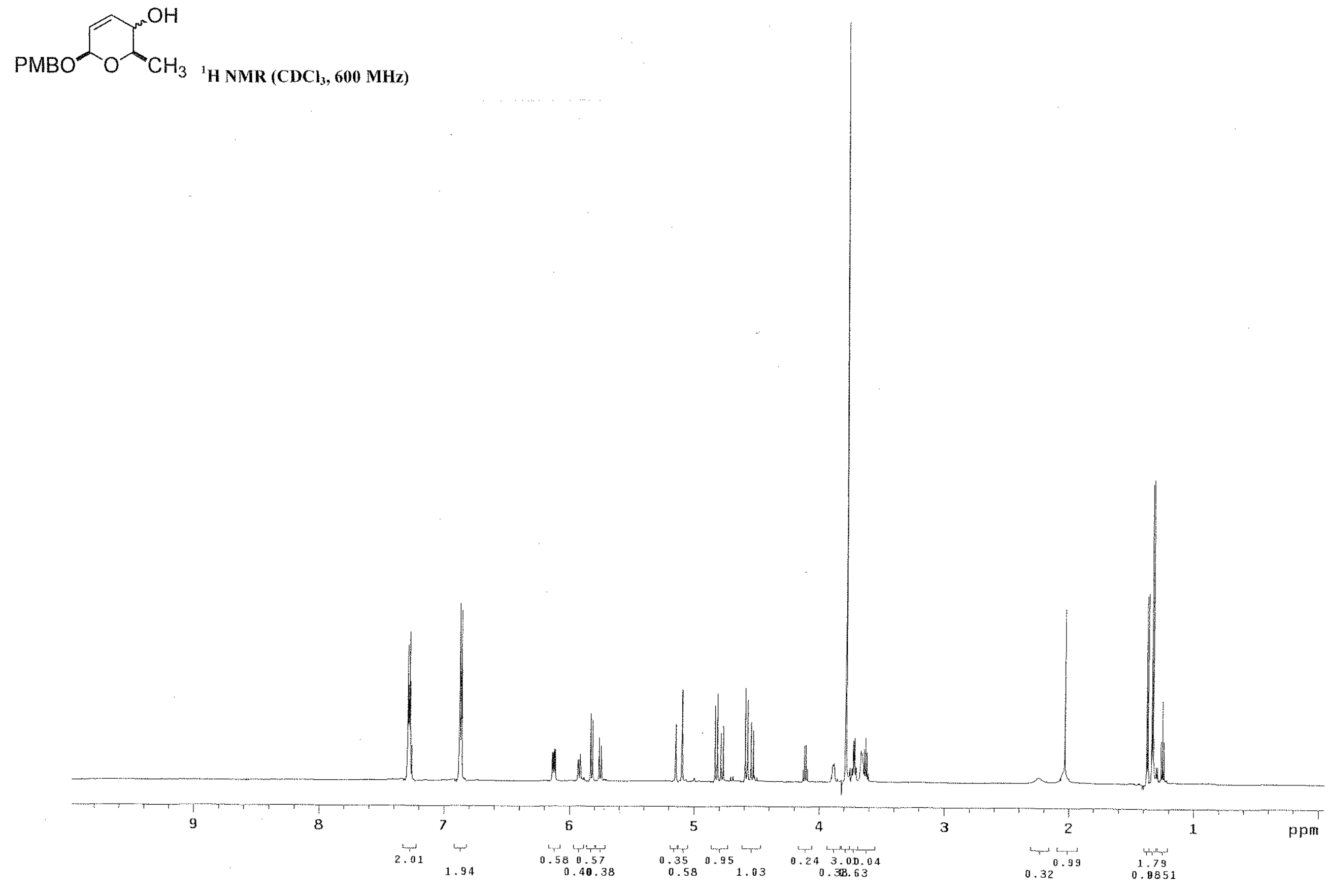
$\mathcal{A}(2 R, 6 R)-2-(4-m e t h o x y b e n z y l o x y)-3,6$-dihydro-6-methyl-2H-pyran (11):

PMBO $\mathrm{O}_{\mathrm{CH}_{3}}{ }^{\mathrm{H}} \mathrm{H} \mathrm{NMR}\left(\mathrm{CDCl}_{3}, 600 \mathrm{MHz}\right)$

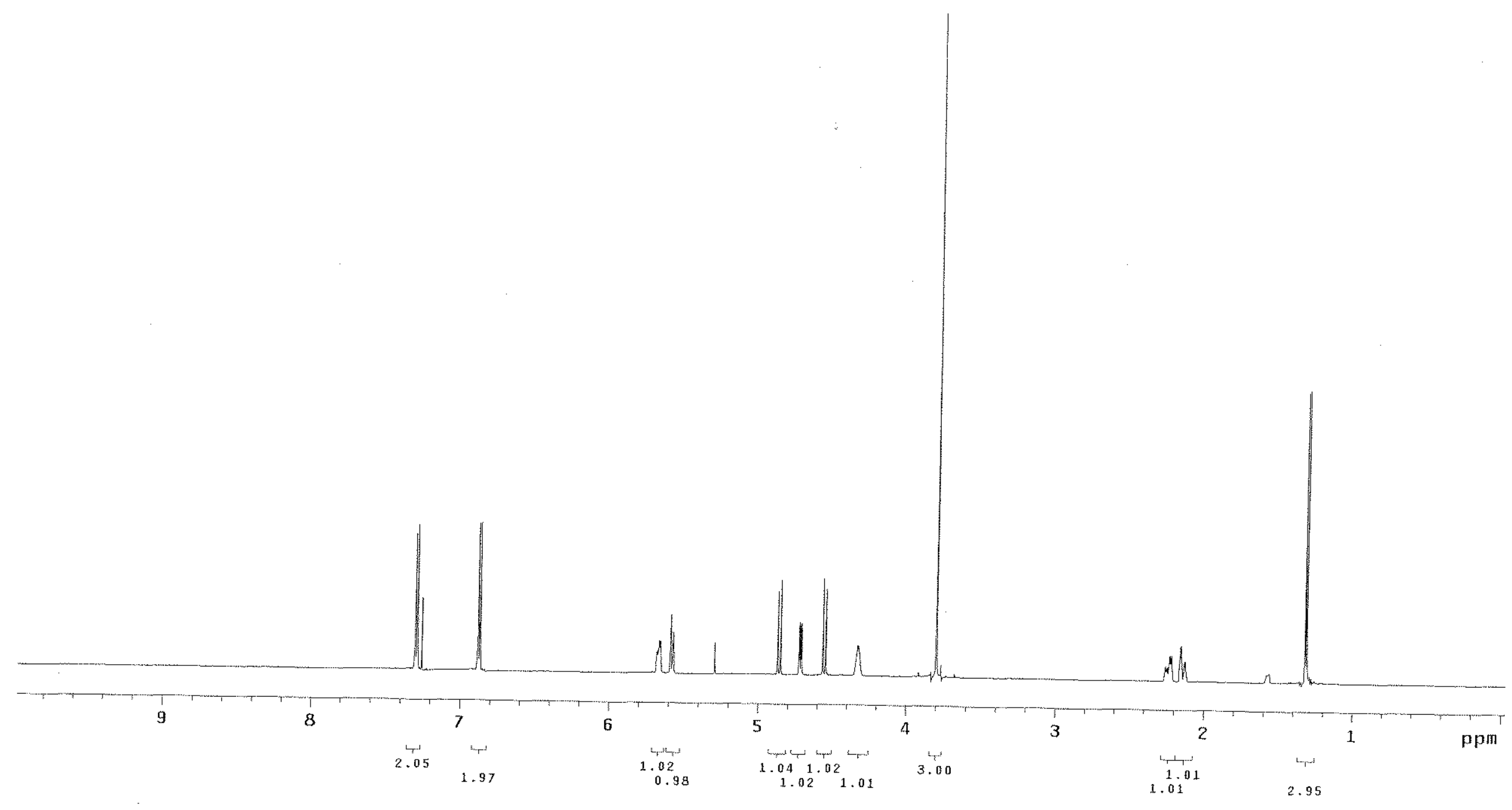


$(2 R, 6 R)-2-(4-m e t h o x y b e n z y l o x y)-3,6-d i h y d r o-6-m e t h y l-2 H-p y r a n ~(11):$
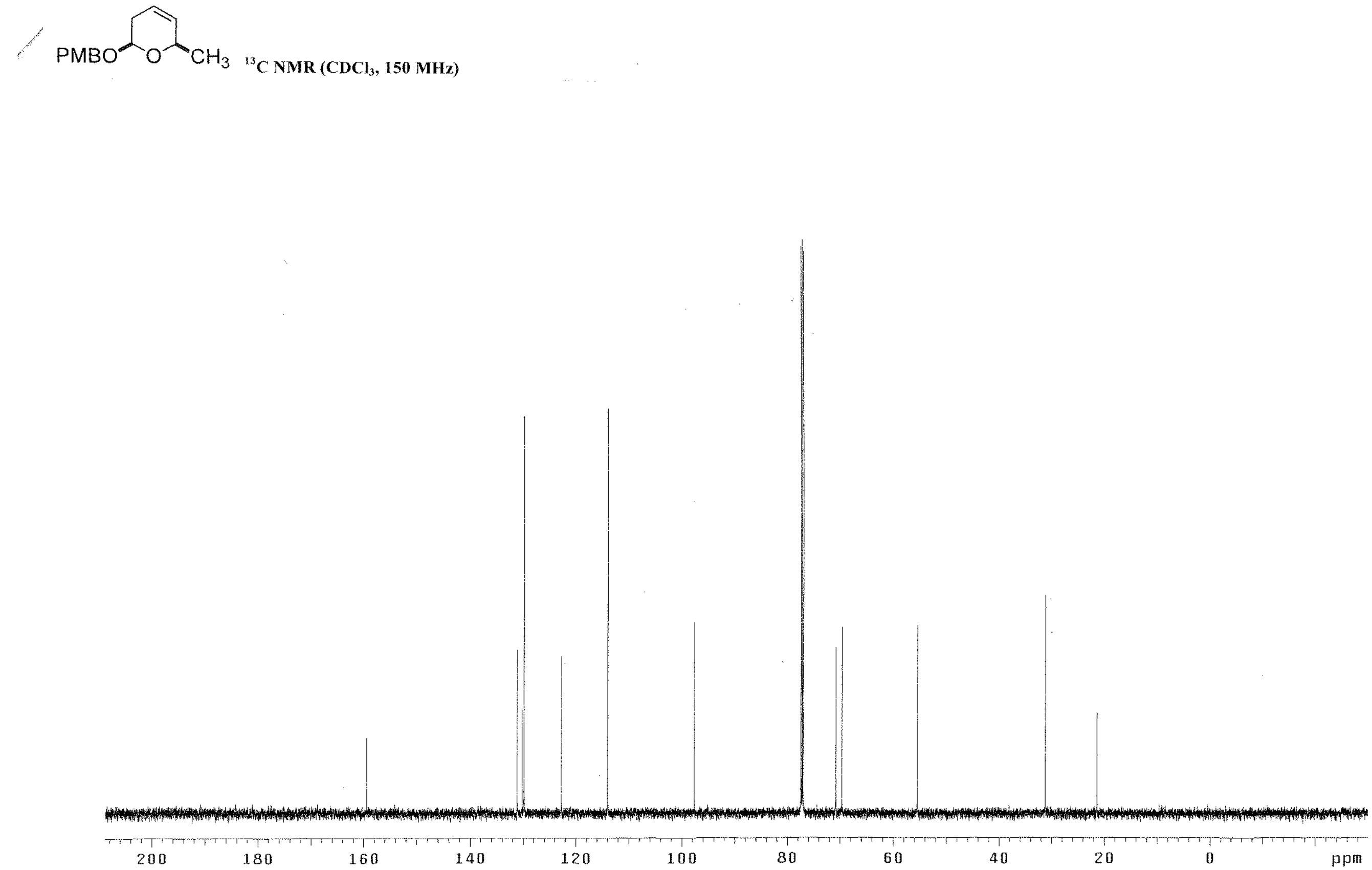
Cyta

(2R,3S,4S,6R)-6-(4-methoxybenzyloxy)-2-methyl-tetrahydron-2H-pyran-3,4-diol (12):<smiles>CCOC(O[Na])C1OC(C)C(O)C(O)C1O</smiles>

${ }^{1} \mathrm{H} \mathrm{NMR}\left(\mathrm{CDCl}_{3}, 600 \mathrm{MHz}\right)$

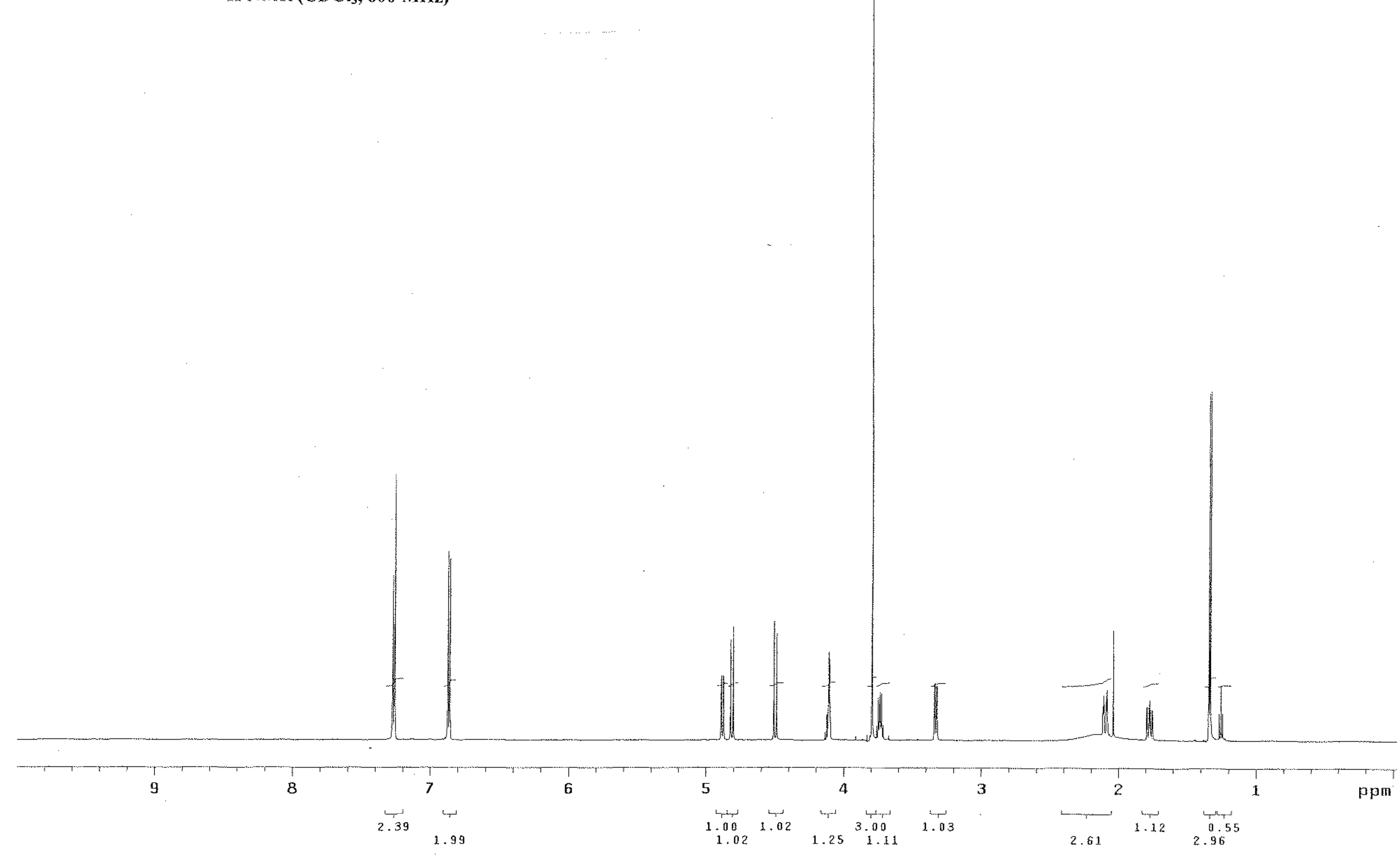


$(2 R, 3 S, 4 S, 6 R)-6-(4-m e t h o x y b e n z y l o x y)-2-m e t h y l-t e t r a h y d r o n-2 H$-pyran-3,4-diol (12):

$\overbrace{\mathrm{OH}}^{\mathrm{Me}} \mathrm{O} O P M B$

${ }^{13} \mathrm{C}$ NMR (CDCl $\left.3,150 \mathrm{MHz}\right)$

How

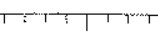

200

180

160

140

120

20 


\section{$\mathrm{Me}$ \\ HO \\ PNBz}

$\left.{ }^{1} \mathrm{H} \mathrm{NMR} \mathrm{(CDCl} 3,600 \mathrm{MHz}\right)$

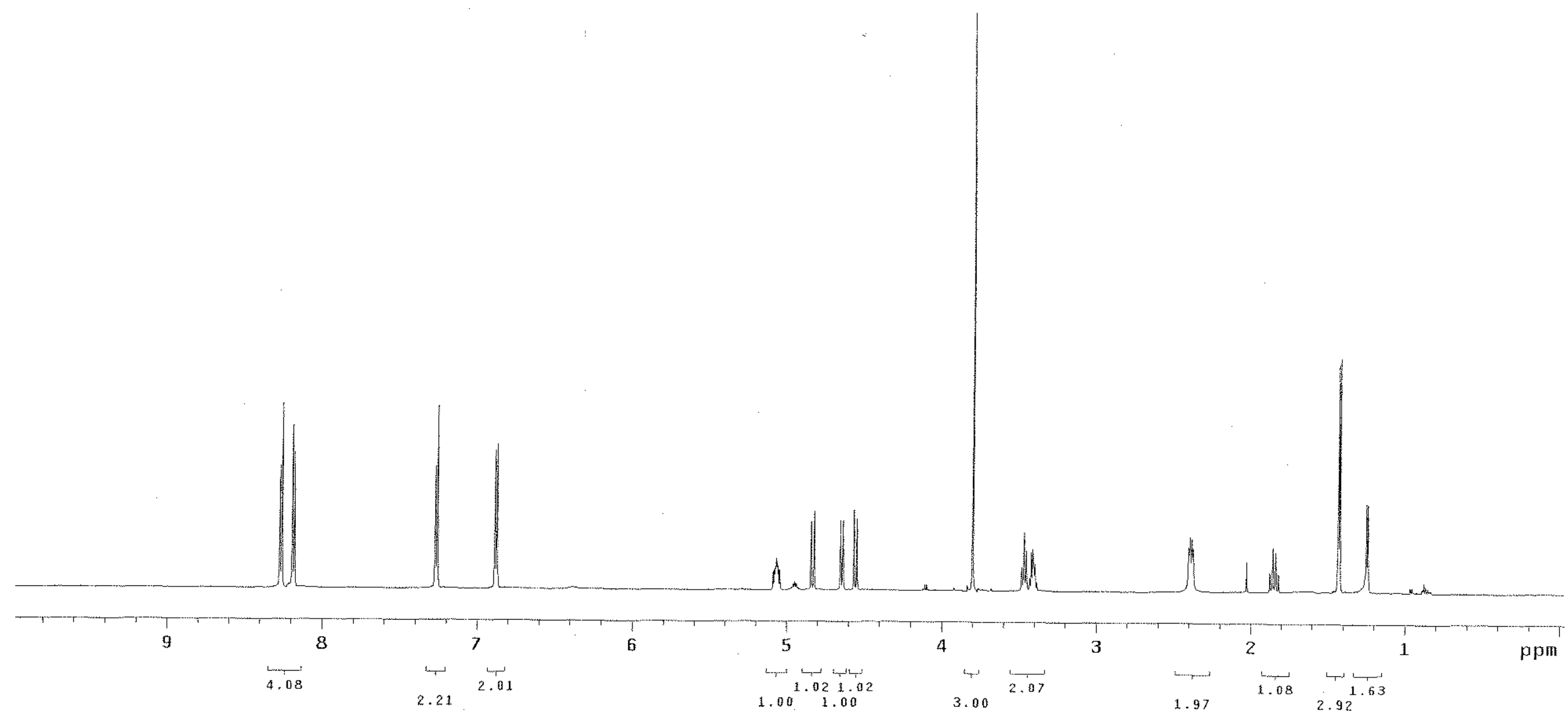


$(2 R, 3 R, 4 R, 6 R)-6-(4-m e t h o x y b e n z y l o x y)$-tetrahydro-3-hyd roxy-2-methyl-2H-py ran-4-yl 4-nitrobenzoate (13):

$\mathrm{Me}$

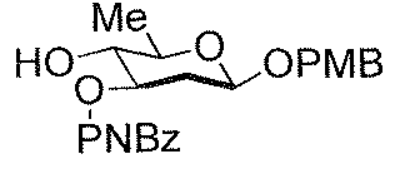

PNBZ

${ }^{13} \mathrm{C} \mathrm{NMR}\left(\mathrm{CDCl}_{3}, 150 \mathrm{MHz}\right)$

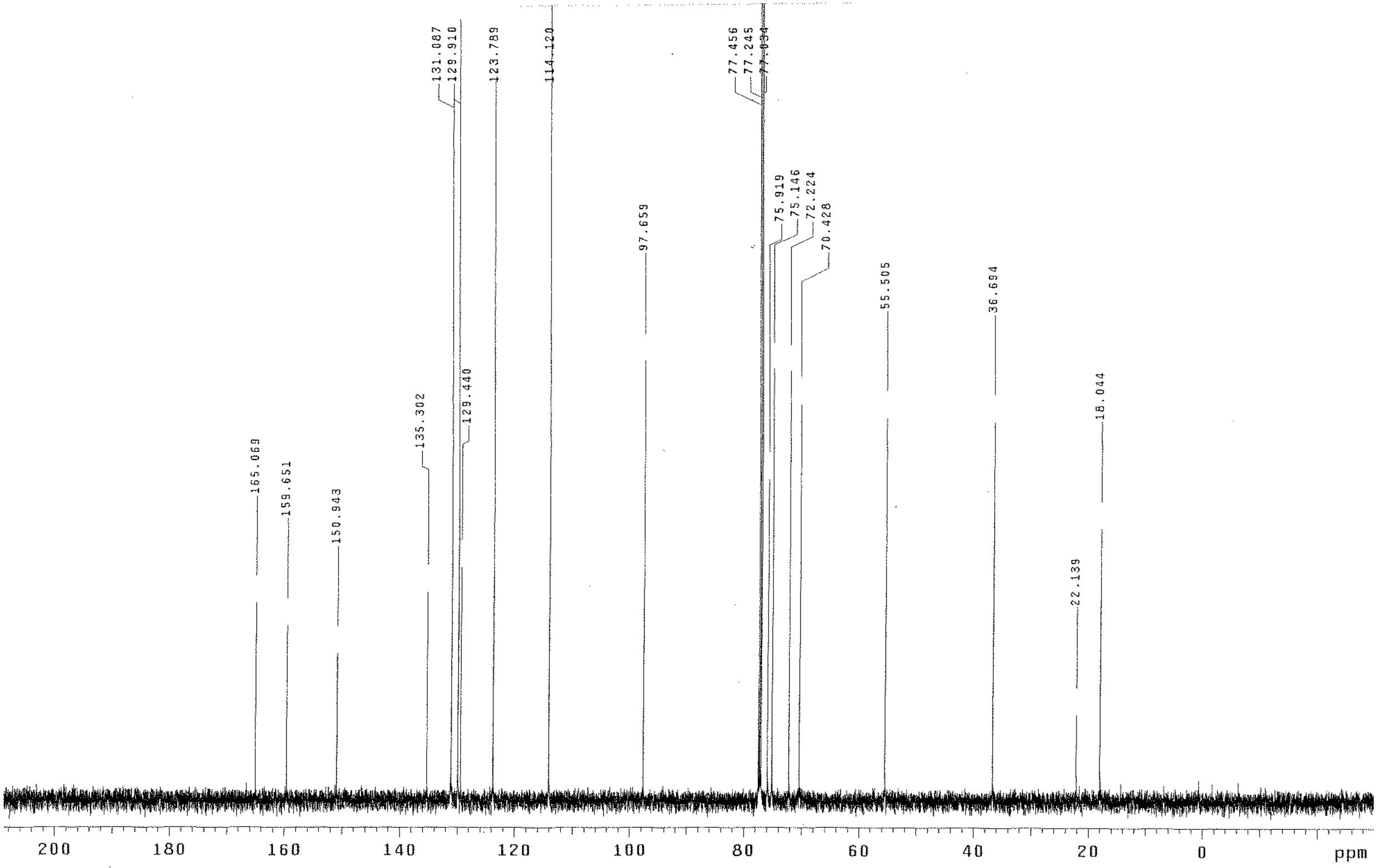


$(2 R, 3 R, 4 R, 6 R)-3-((2 R, 6 S)-5,6$-dihydro-6-methyl-5-oxo-2H-pyran-2-yloxy)-6-(4-methoxybenzyloxy)-tetrahydro-2methyl-2H-pyran-4-yl 4-nitrobenzoate (14):

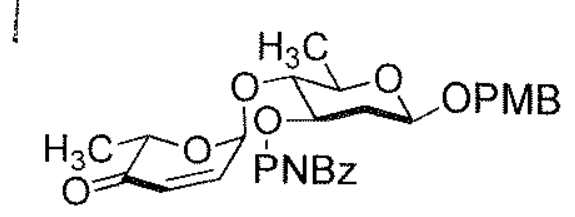

${ }^{1} \mathrm{H}$ NMR $\left(\mathrm{CDCl}_{3}, 600 \mathrm{MHz}\right)$

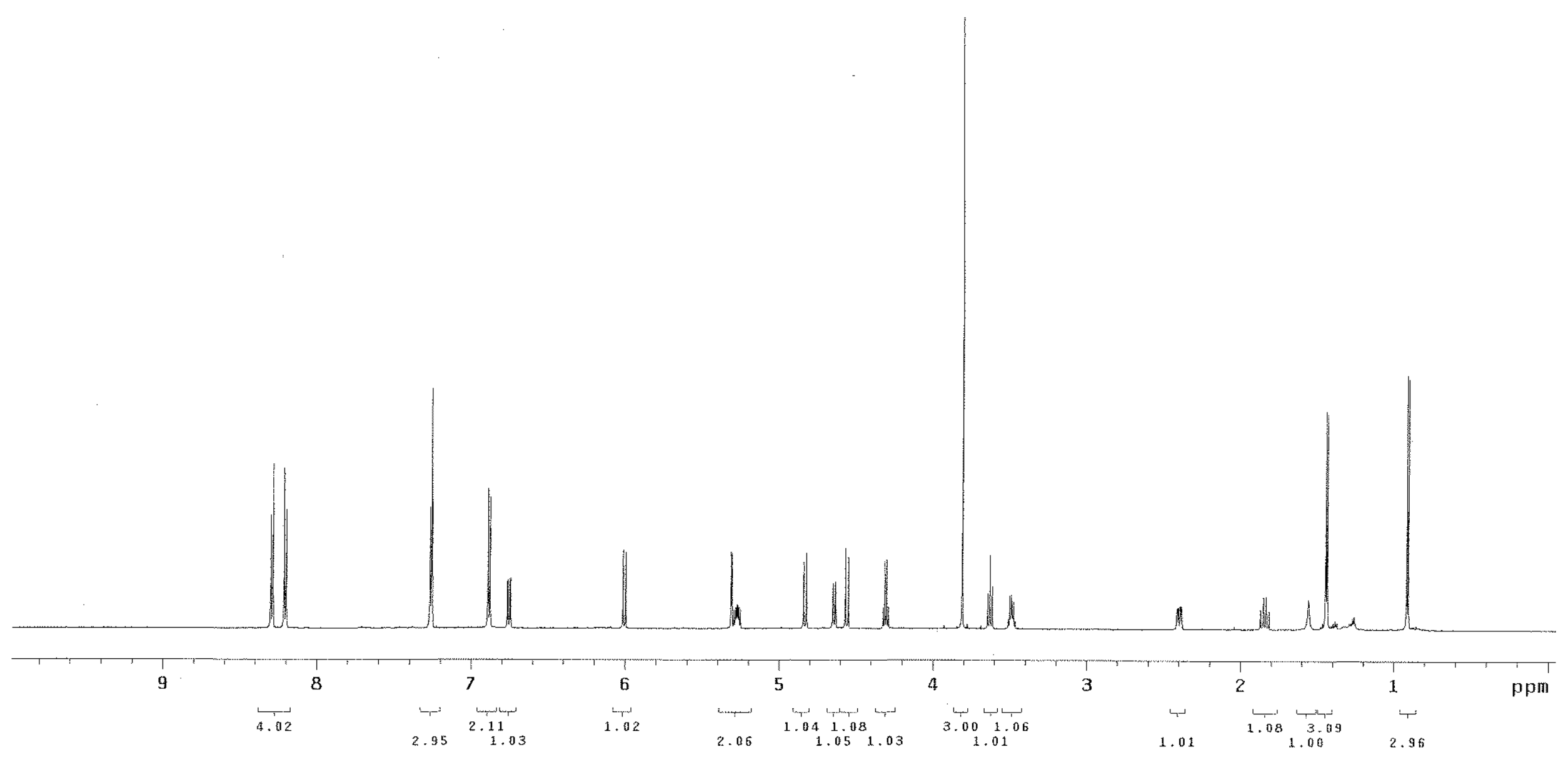


$(2 R, 3 R, 4 R, 6 R)-3-((2 R, 6 S)-5,6-$ dihydro-6-methyl-5-0x0-2H-pyran-2-yloxy)-6-(4-methoxybenzyloxy)-tetrahydro-2-

methyl-2H-pyran-4-yl 4-nitrobenzoate (14):

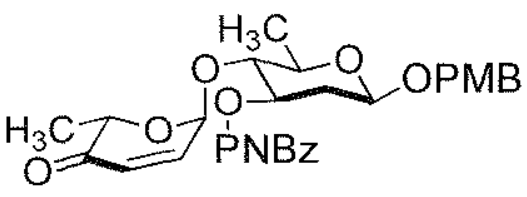

${ }^{13} \mathrm{C} \mathrm{NMR}\left(\mathrm{CDCl}_{3}, 150 \mathrm{MHz}\right)$

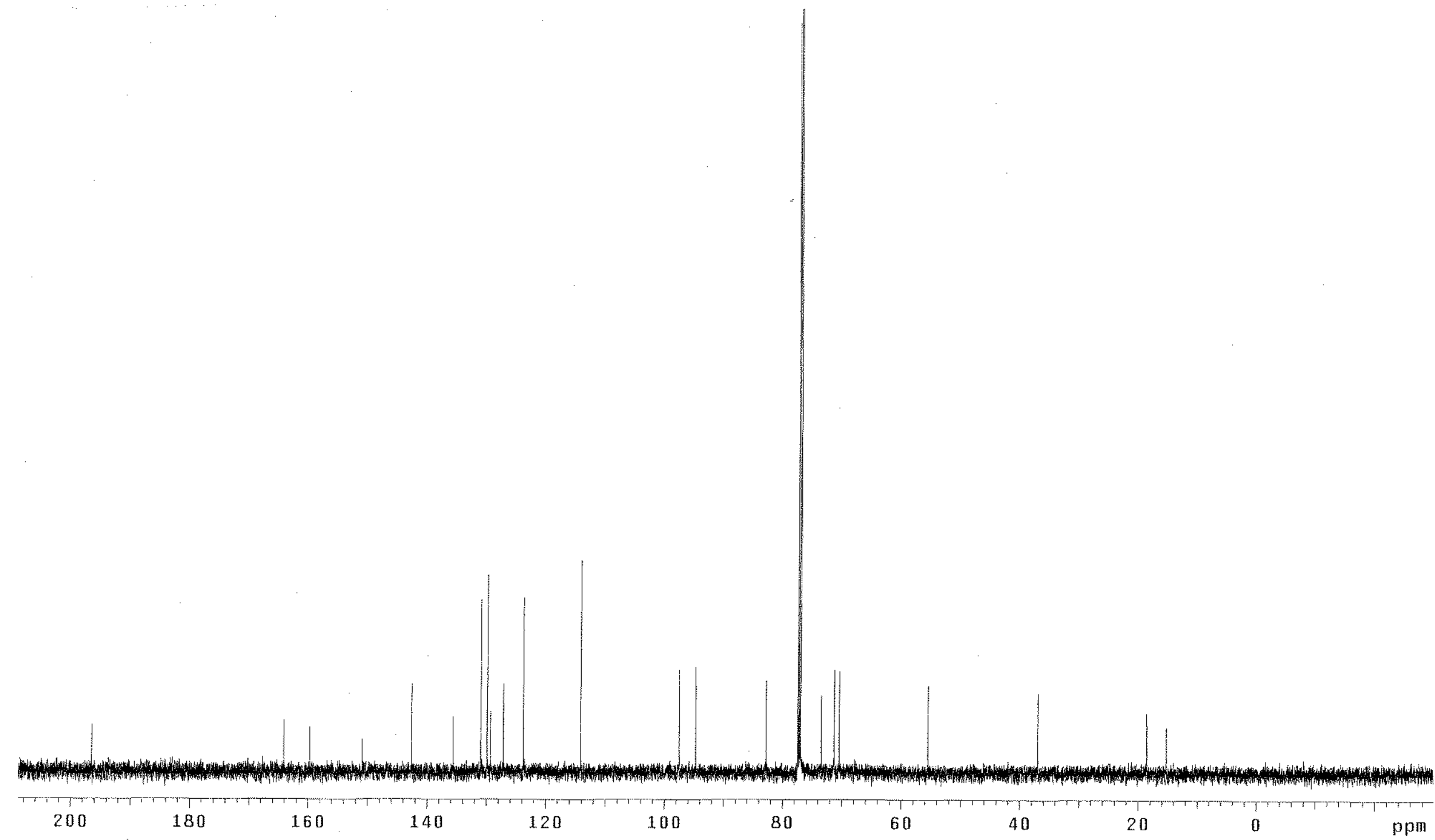


$(2 R, 3 R, 4 R, 6 R)-3-((2 R, 5 R, 6 S)-5,6$-dihydro-5-hydroxy-6-methyl-2H-pyran-2-yloxy)-6-(4-methoxybenzyloxy)-

tetrahydro-2-methyl-2H-pyran-4-yl 4-nitrobenzoate (15):

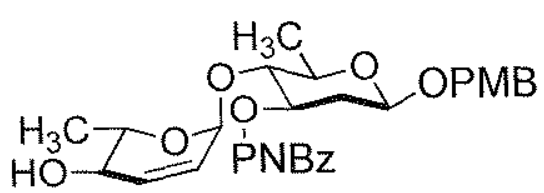

${ }^{1} \mathrm{H} \mathrm{NMR}\left(\mathrm{CDCl}_{3}, 600 \mathrm{MHz}\right)$

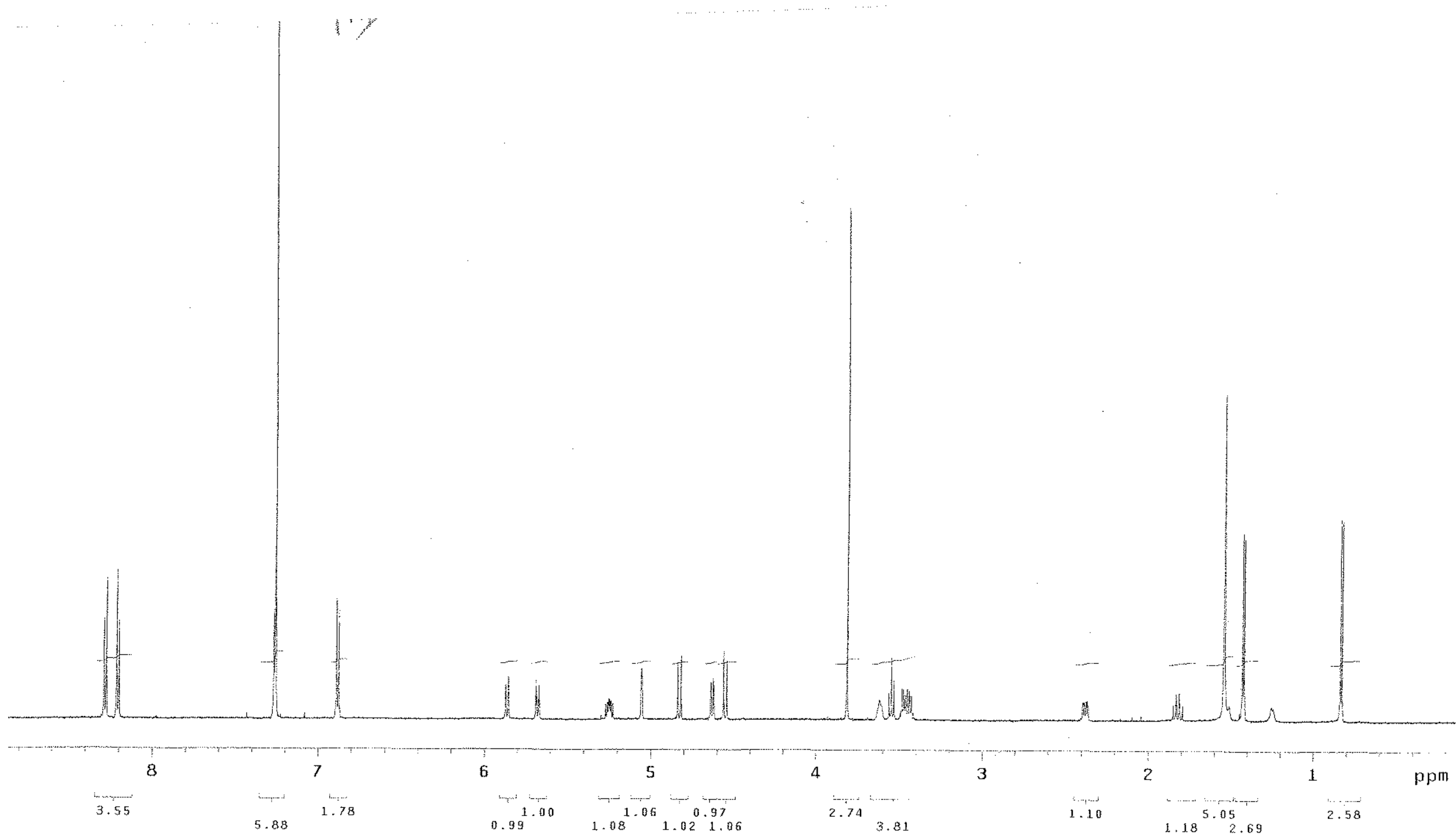


$(2 R, 3 R, 4 R, 6 R)-3-((2 R, 5 R, 6 S)-5,6$-dihydro-5-hydroxy-6-methyl-2H-pyran-2-yloxy)-6-(4-methoxybenzyloxy)-

tetrahydro-2-methyl-2H-pyran-4-yl 4-nitrobenzoate (15):

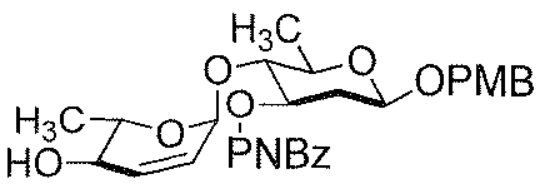

${ }^{13} \mathrm{C} \mathrm{NMR}\left(\mathrm{CDCl}_{3}, 150 \mathrm{MHz}\right)$

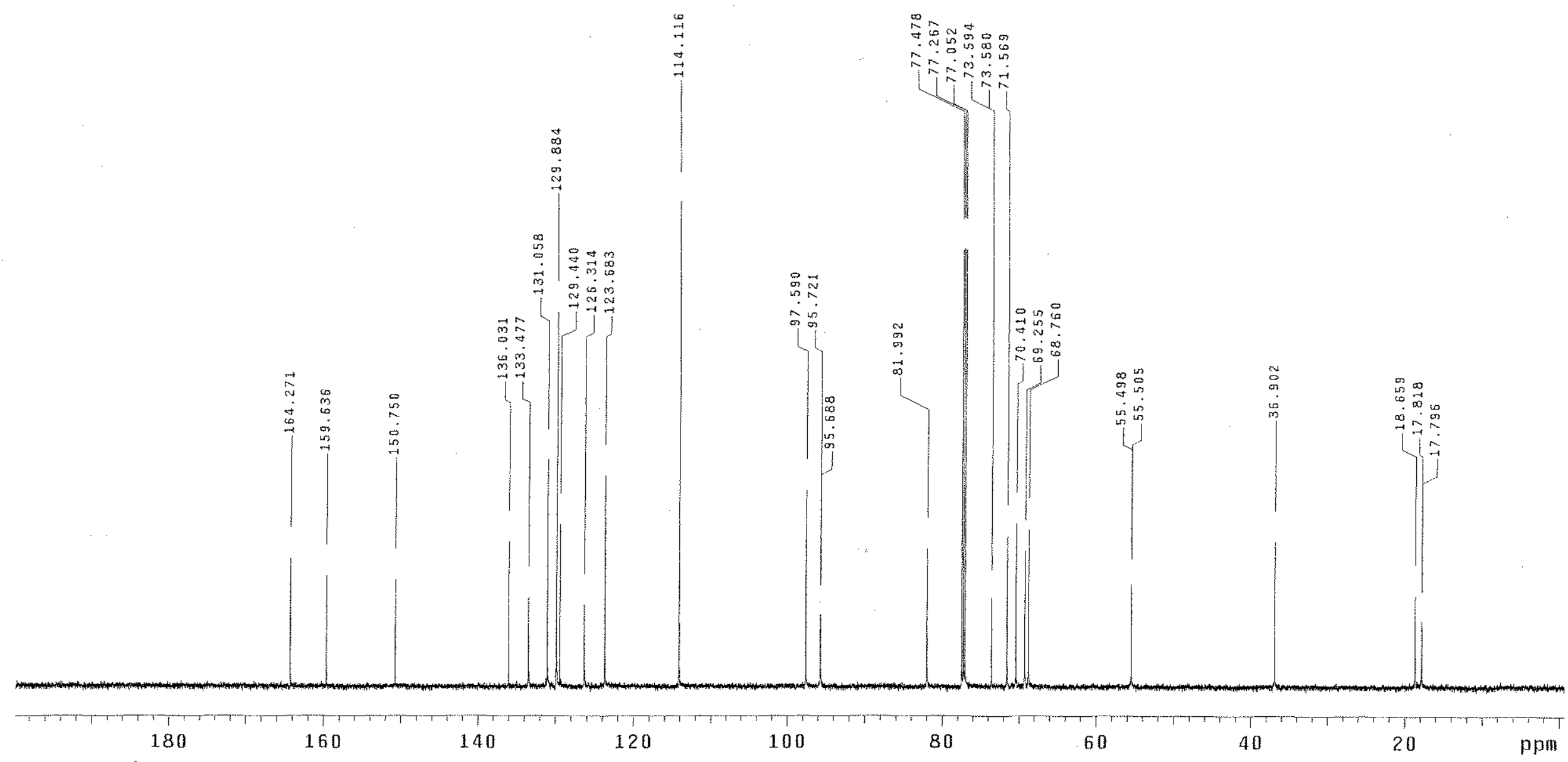


tetrahydro-2-methyl-2H-pyran-4-yl 4-nitrobenzoate (16):

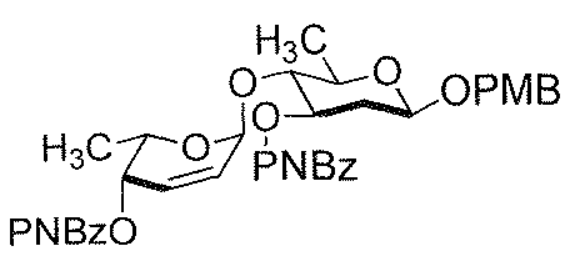

\section{$\mathrm{PNBZO}$}

${ }^{1} \mathrm{H} \mathrm{NMR}\left(\mathrm{CDCl}_{3}, 600 \mathrm{MHz}\right)$

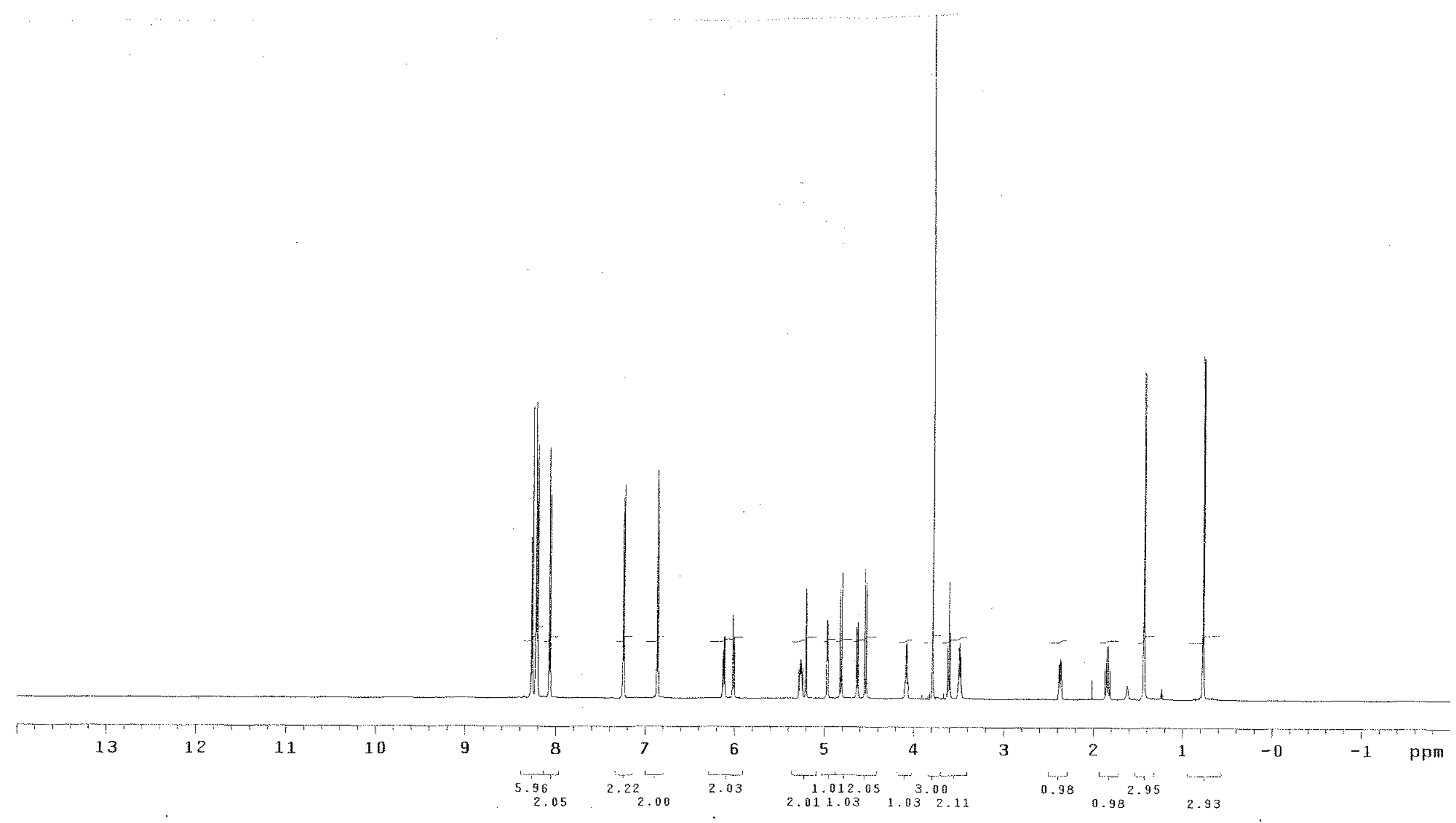


$(2 R, 3 R, 4 R, 6 R)-3-((2 R, 5 R, 6 S)-5,6-d i h y d r 0-5-(4-n i t r o b e n z o a t e)-6-m e t h y l-2 H$-pyran-2-yloxy)-6-(4-methoxybenzyloxy)-

tetrahydro-2-methyl-2H-pyran-4-yl 4-nitrobenzoate (16):

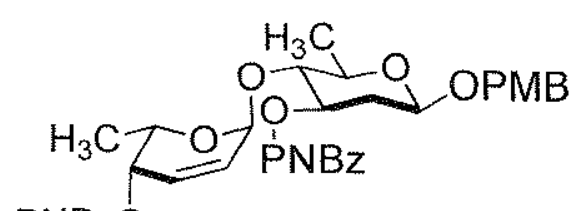

PNBzO

${ }^{13} \mathrm{C} \mathrm{NMR}\left(\mathrm{CDCl}_{3}, 150 \mathrm{MHz}\right)$

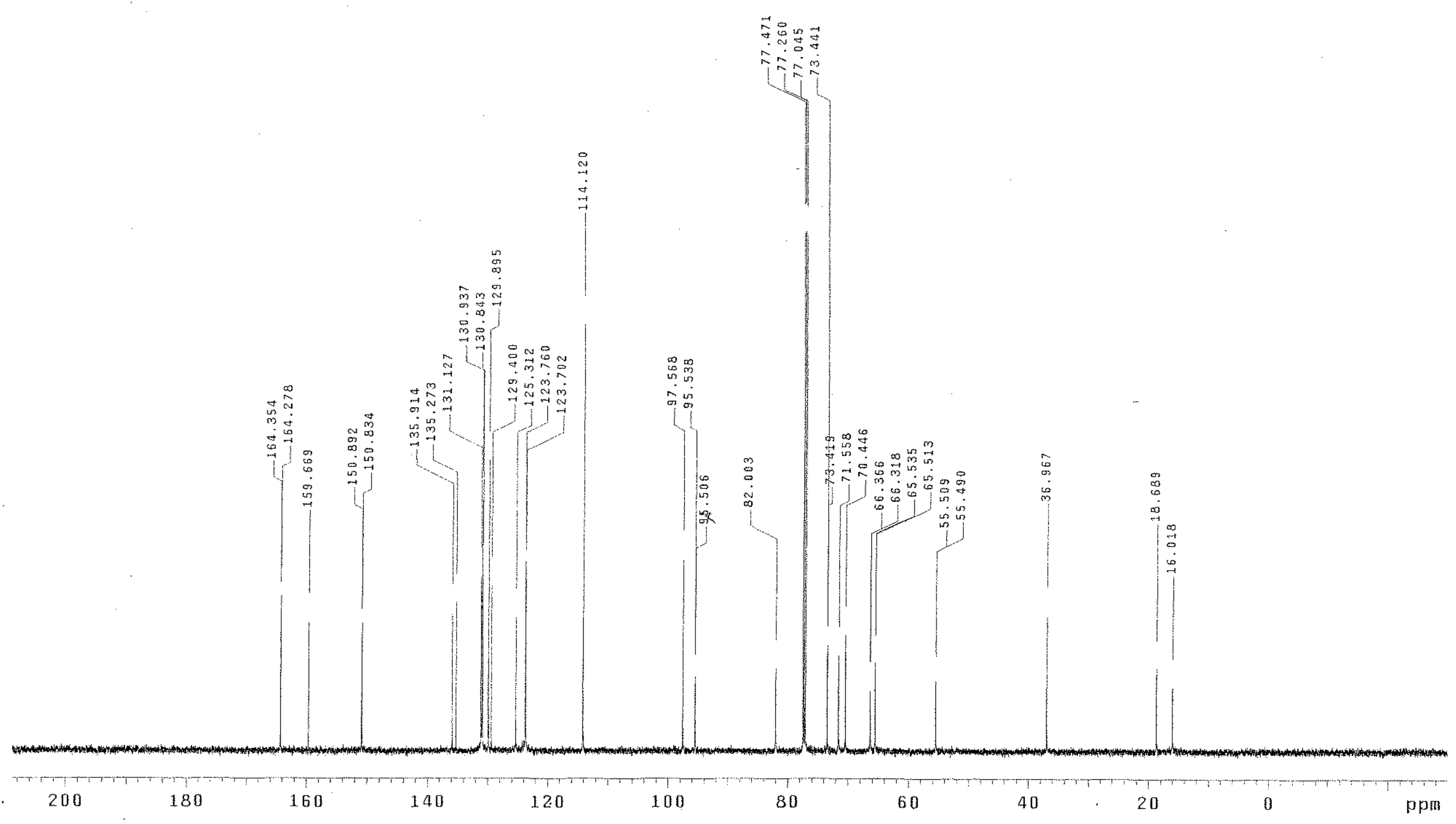




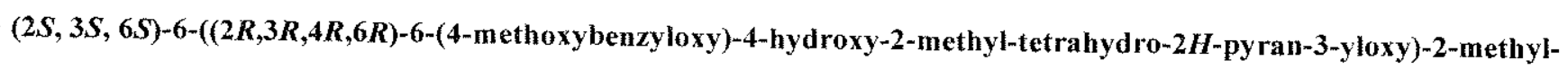

3,6-dihydro-2H-pyran-3-ol (17):

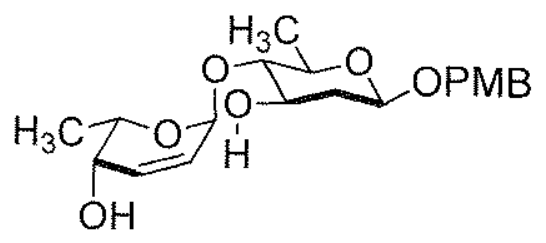

${ }^{1} \mathrm{H} \mathrm{NMR}\left(\mathrm{CDCl}_{3}, 600 \mathrm{MHz}\right)$

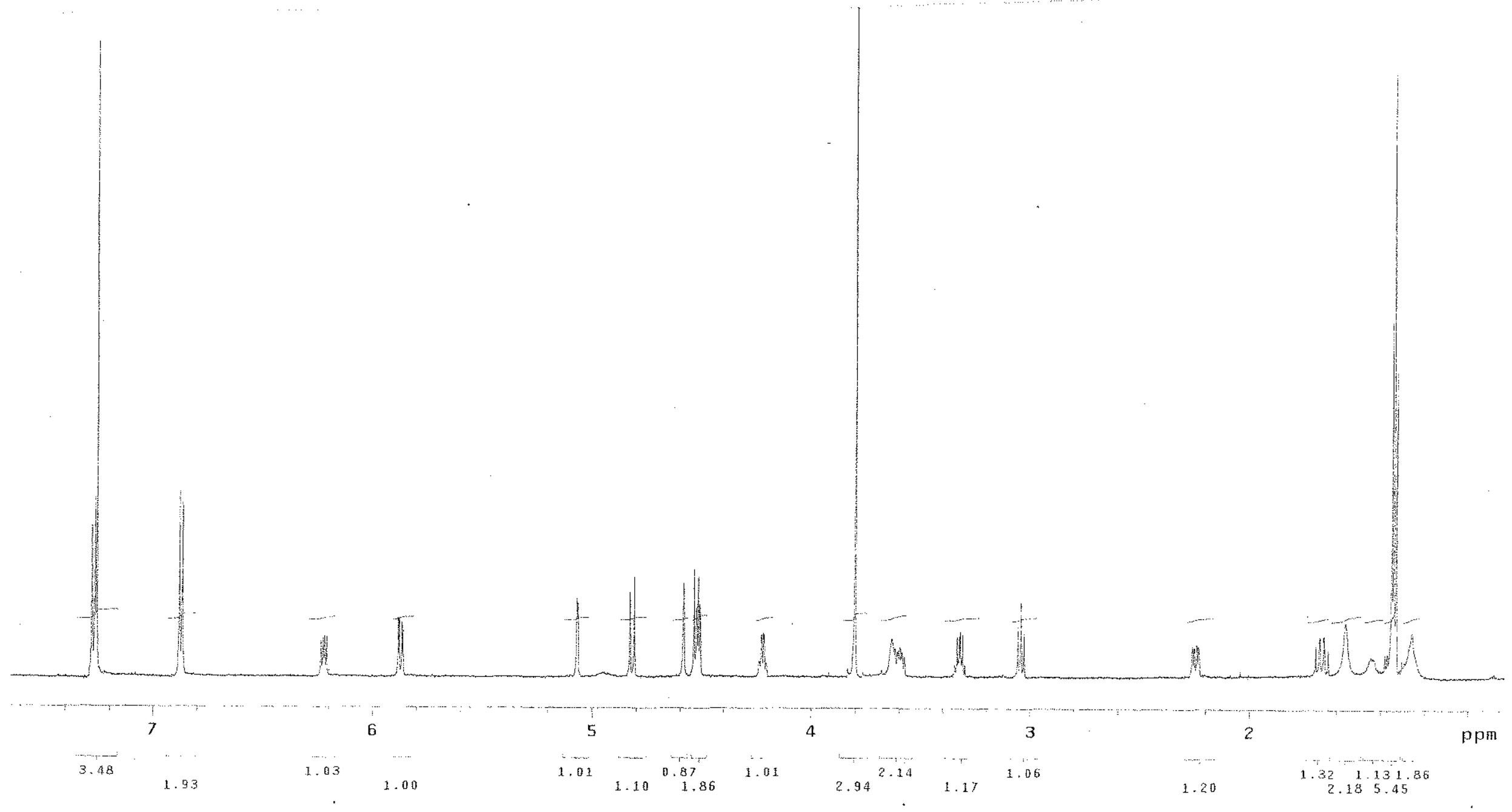


$(2 S, 3 S, 6 S)-6-((2 R, 3 R, 4 R, 6 R)-6-(4-m e t h o x y b e n z y l o x y)-4-h y d r o x y-2-m e t h y l-t e t r a h y d r o-2 H$-pyran-3-yloxy)-2-methyl3,6-dihydro-2H-pyran-3-ol (17):

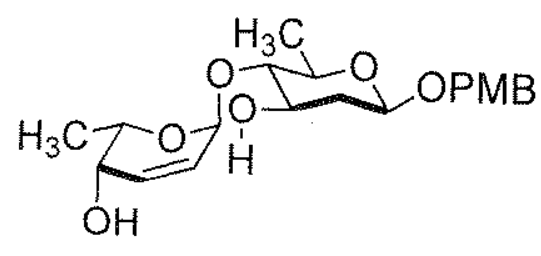

${ }^{13} \mathrm{C} \mathrm{NMR}\left(\mathrm{CDCl}_{3}, 150 \mathrm{MHz}\right)$

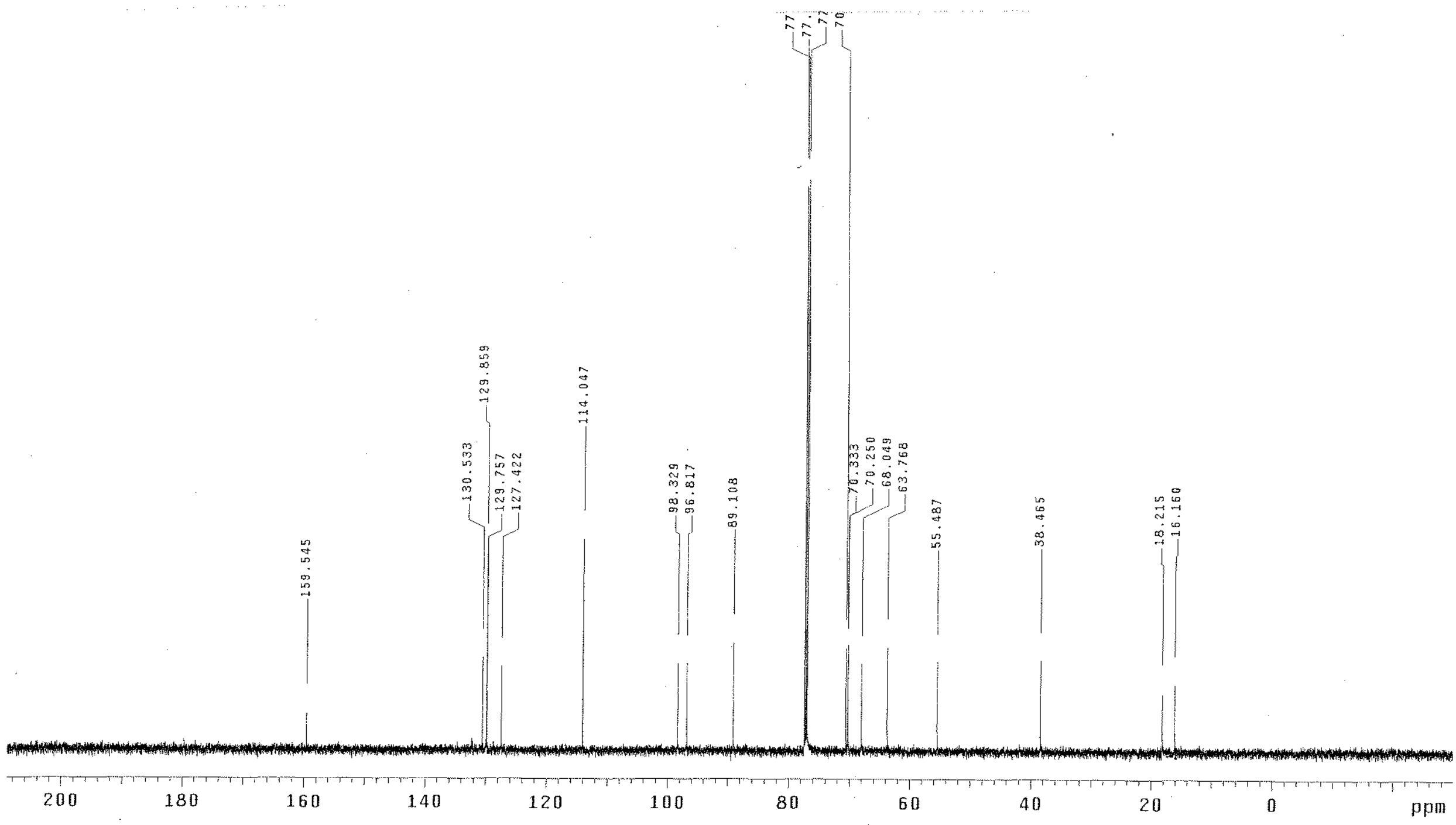




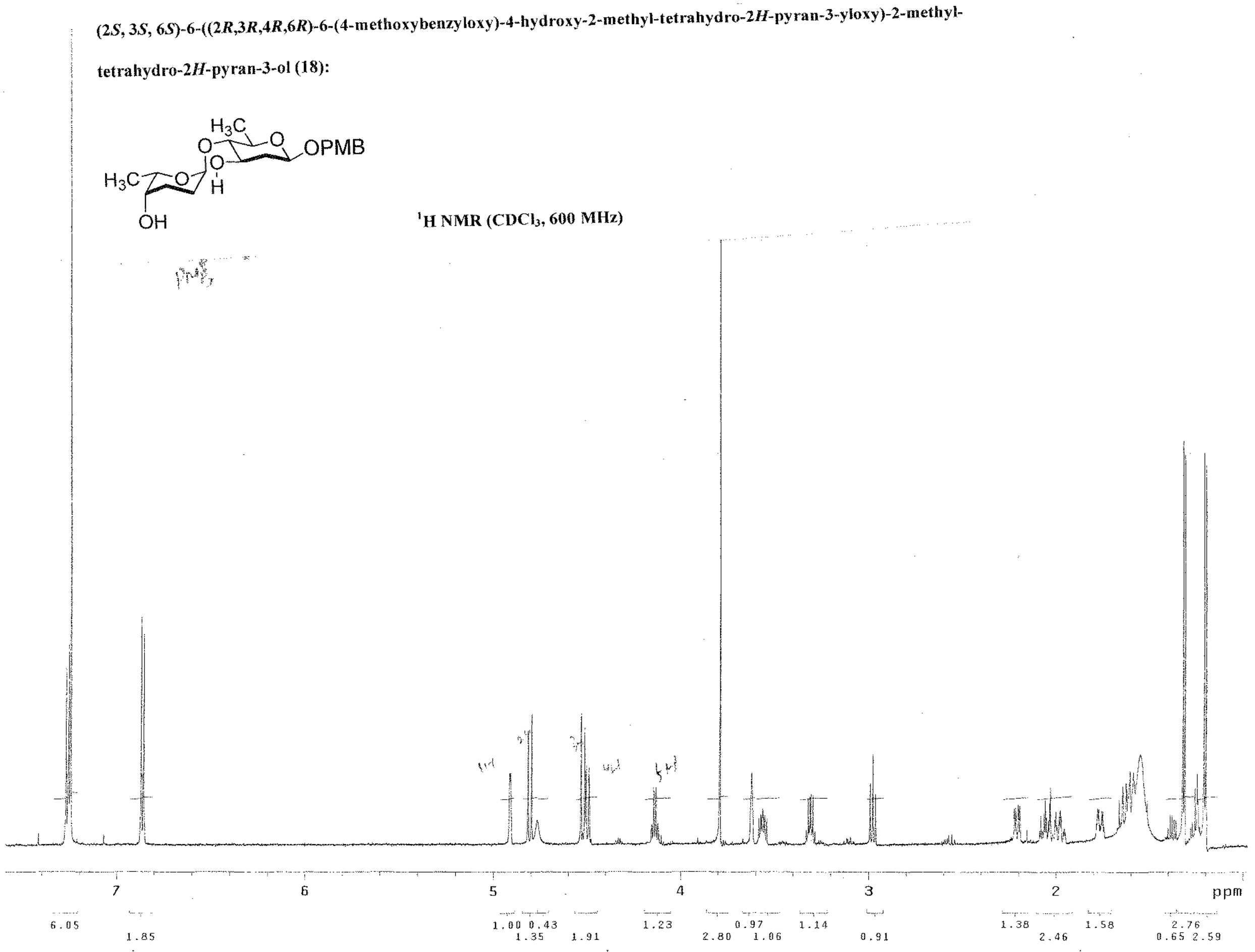


$(2 S, 3 S, 6 S)-6-((2 R, 3 R, 4 R, 6 R)-6-(4-m e t h o x y b e n z y l o x y)-4-h y d r o x y-2-m e t h y l-t e t r a h y d r o-2 H$-py ran-3-yloxy)-2-methyl-

tetrahydro-2H-pyran-3-ol (18):

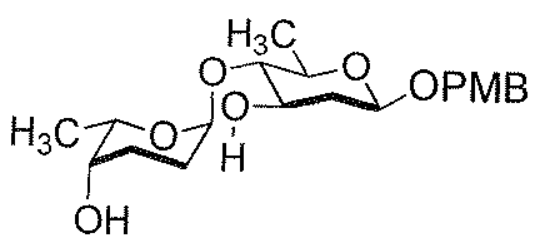

${ }^{13} \mathrm{C} \mathrm{NMR}\left(\mathrm{CDCl}_{3}, 150 \mathrm{MHz}\right)$

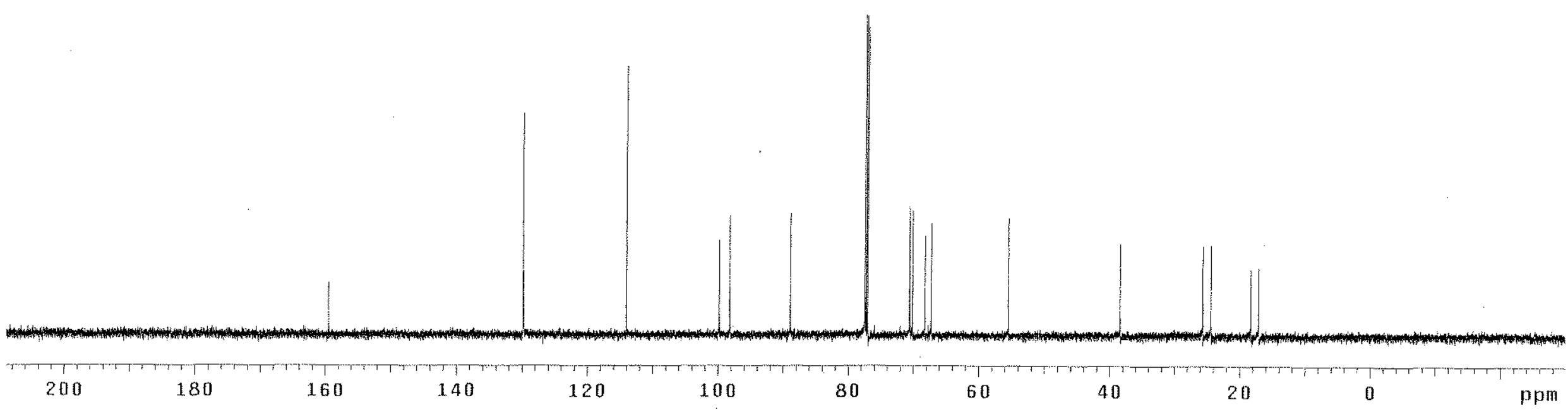




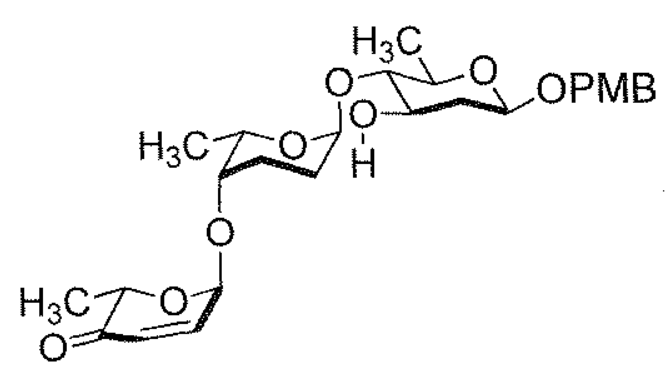

${ }^{\text {I}} \mathrm{H} \mathrm{NMR}\left(\mathrm{CDCl}_{3}, 600 \mathrm{MHz}\right)$

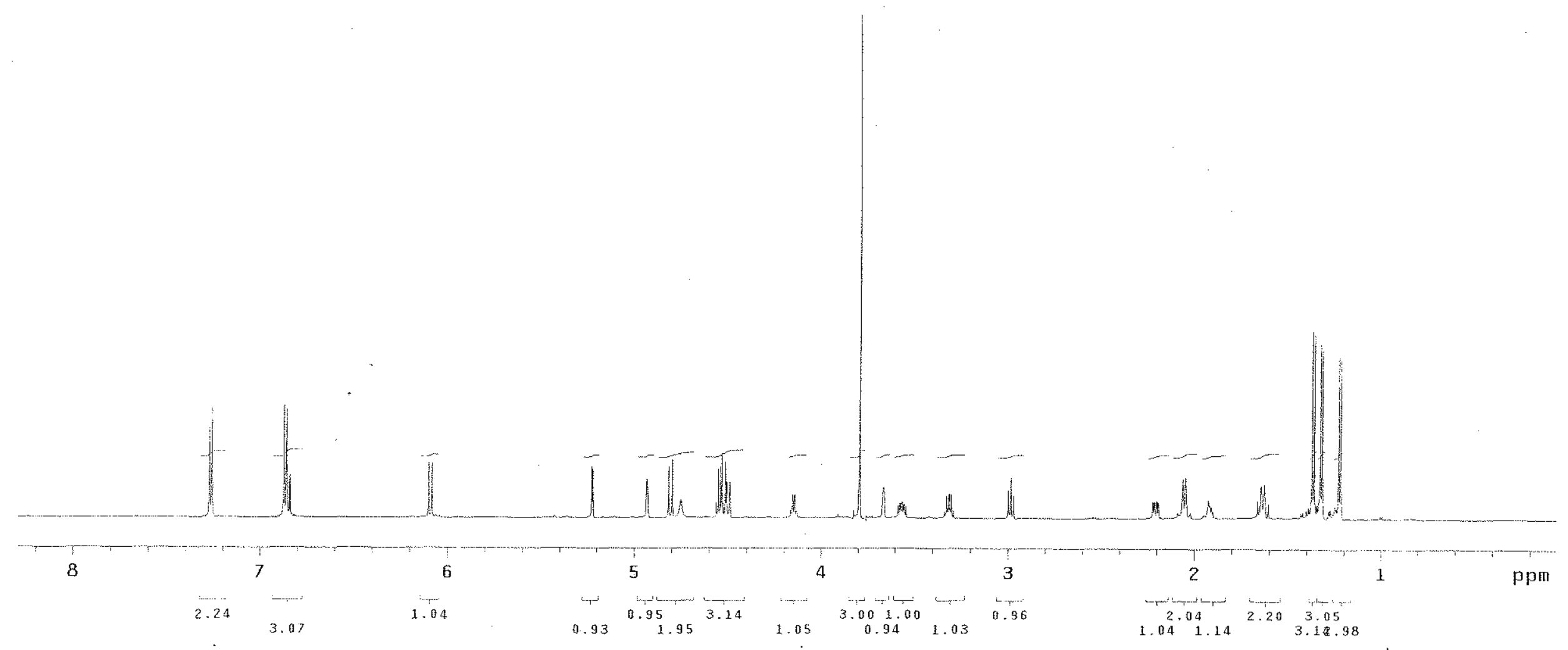


$(2 S, 6 R)-6-((2 S, 3 S, 6 S)-6-((2 R, 3 S, 4 R, 6 R)-6-(4-m e t h o x y b e n z y l o x y)-4-h y d r o x y-2-m e t h y l-t e t r a h y d r o-2 H-p y r a n-3-y l o x y)-2-$ methyl-tetrahydro-2H-pyran-3-yloxy)-2-methyl-2H-3(6H)-one (19):

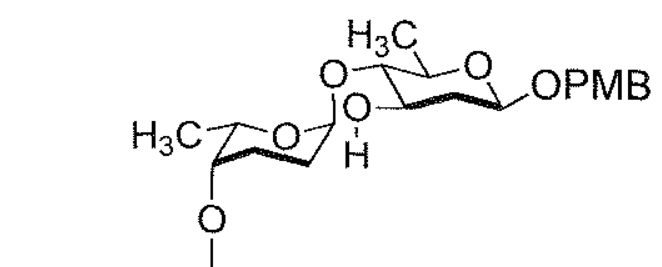

$\mathrm{H}_{3} \mathrm{COO}$
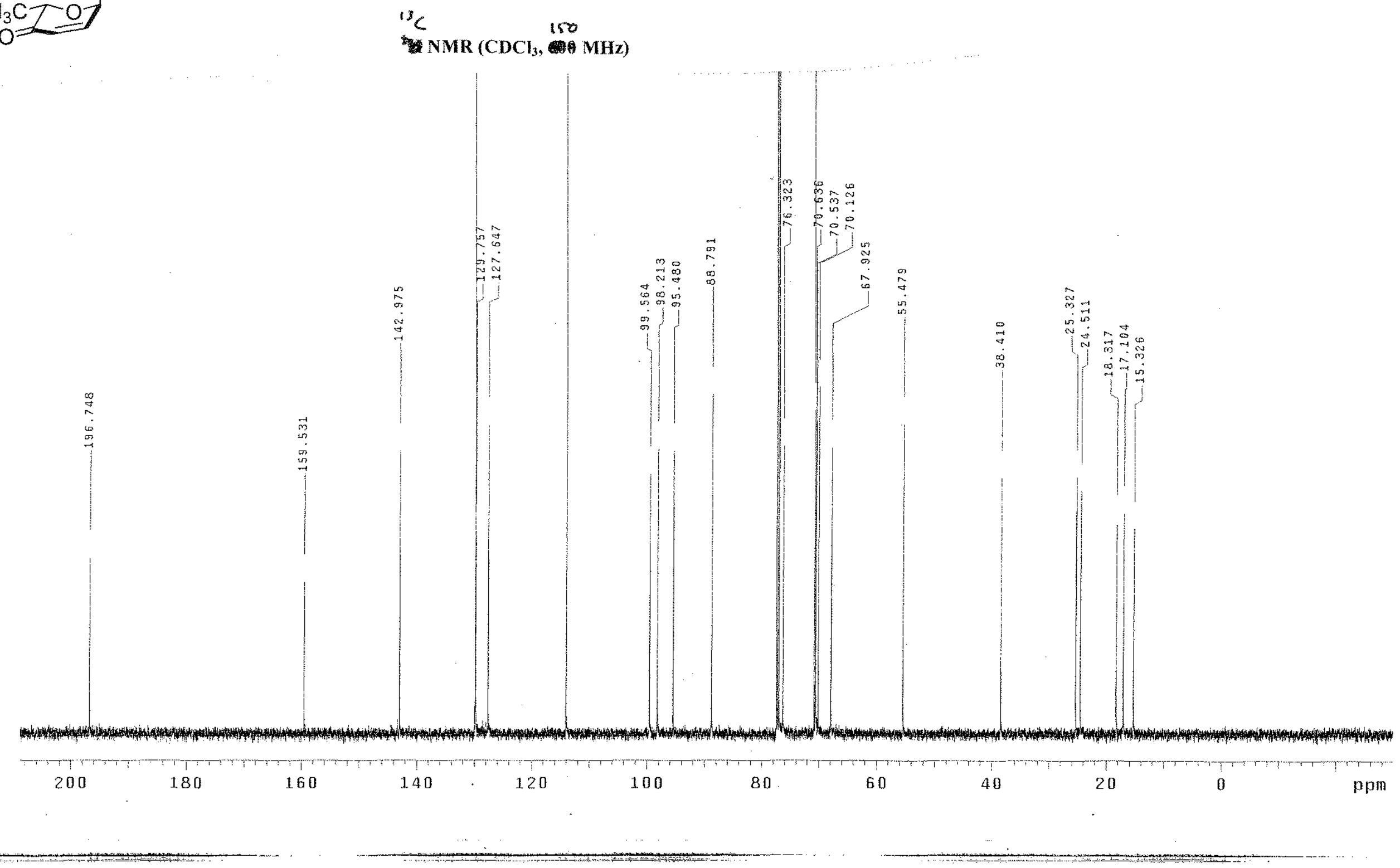
(2R,3S,4R,6R)-6-(4-methoxybenzyloxy)-2-methyl-3-((2S,5S,6S)-6-methyl-5-((2R,6S)-6-methyl-5-oxo-5,6-dihydro-2H-

pyran-2-yloxy)-tetrahydro-2H-pyran-2-yloxy)-tetrahydro-2H-pyran-4-yl acetate (20):

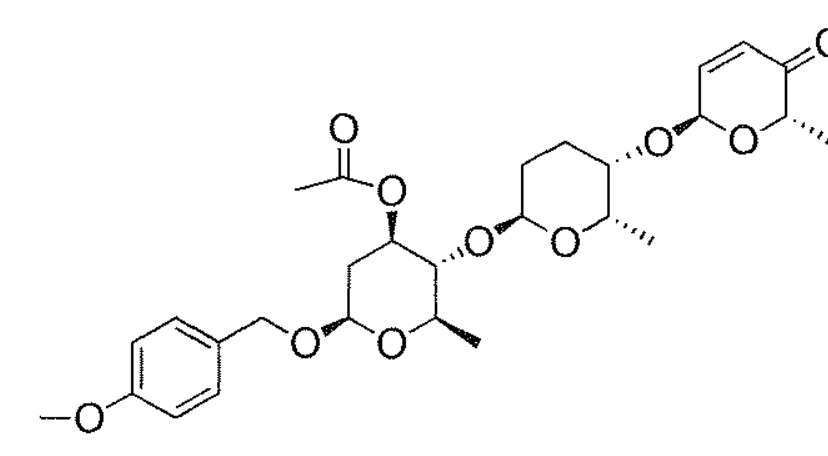

${ }^{1} \mathrm{H}$ NMR $\left(\mathrm{CDCl}_{3}, 600 \mathrm{MHz}\right)$

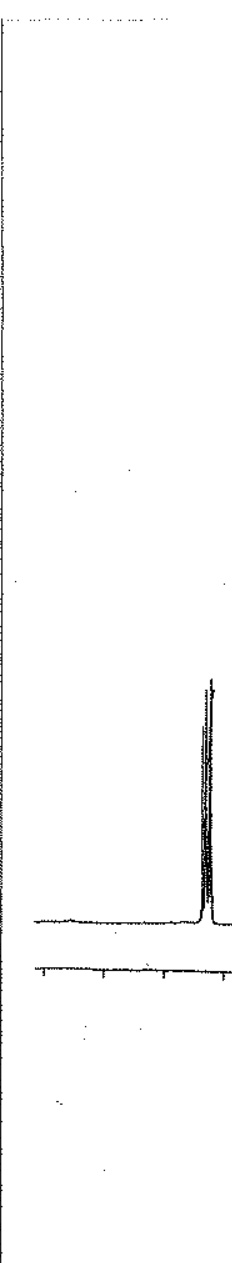

U

20<smiles>N#CC(=O)OCCN</smiles> 


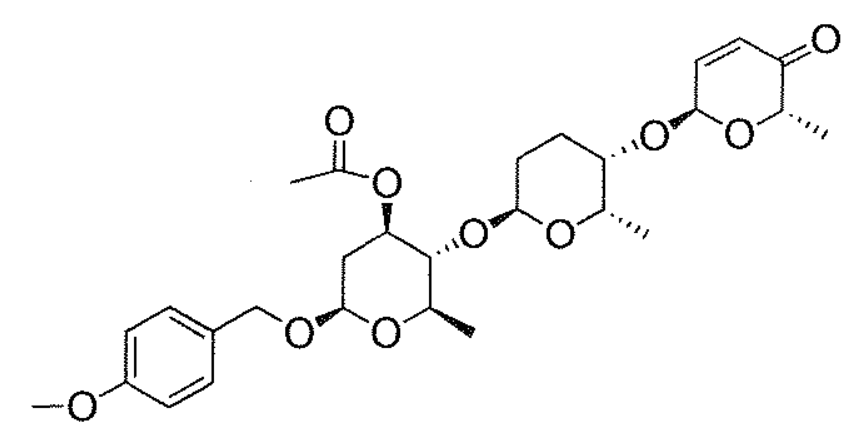

${ }^{13} \mathrm{C}$ NMR $\left(\mathrm{CDCl}_{3}, 150 \mathrm{MHz}\right)$

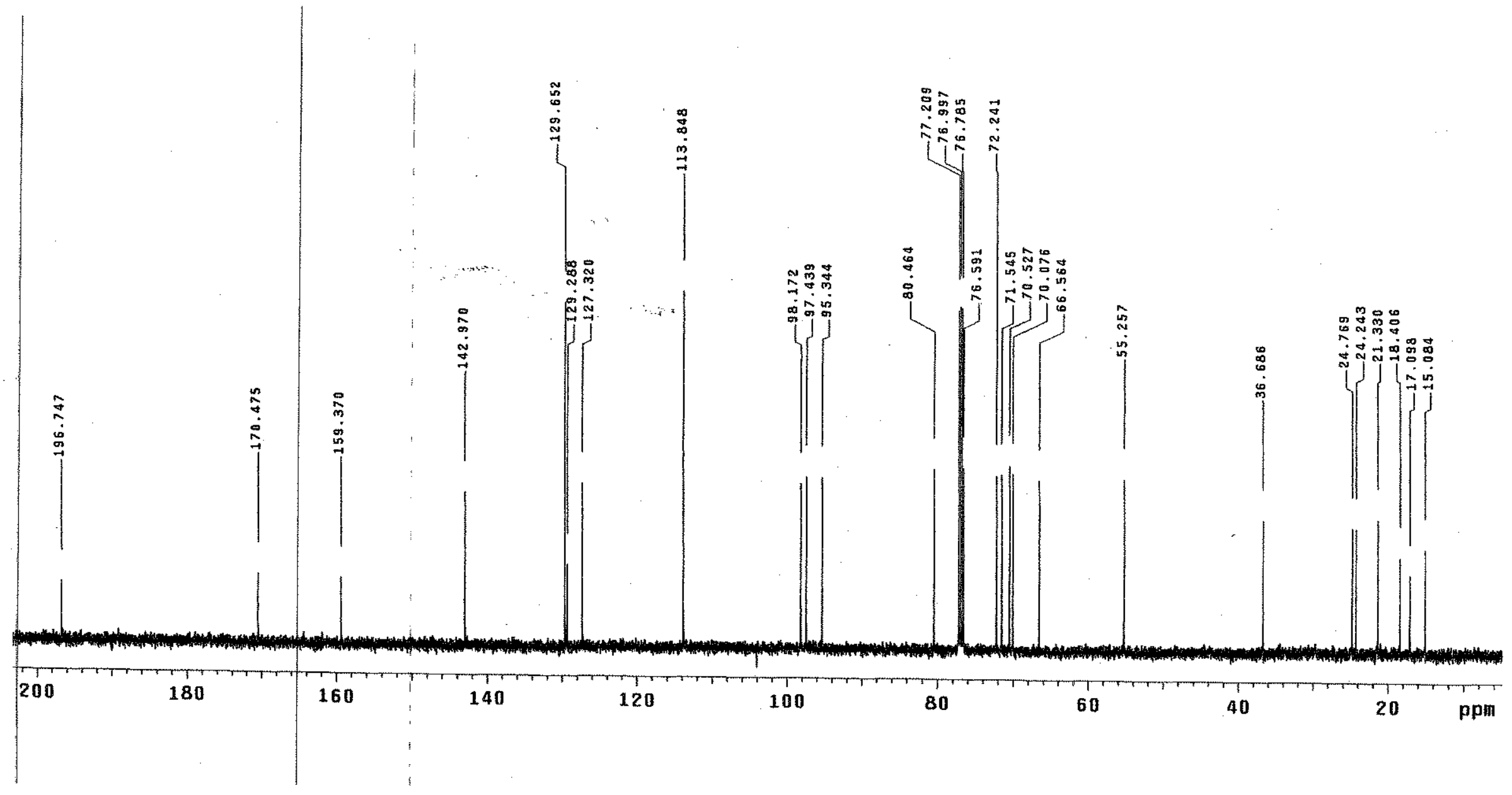


$(2 S, 6 S)-6-(4-m e t h o x y b e n z y l o x y)-2-$ methyl-2H-pyran-3(6H)-one (ent-9)
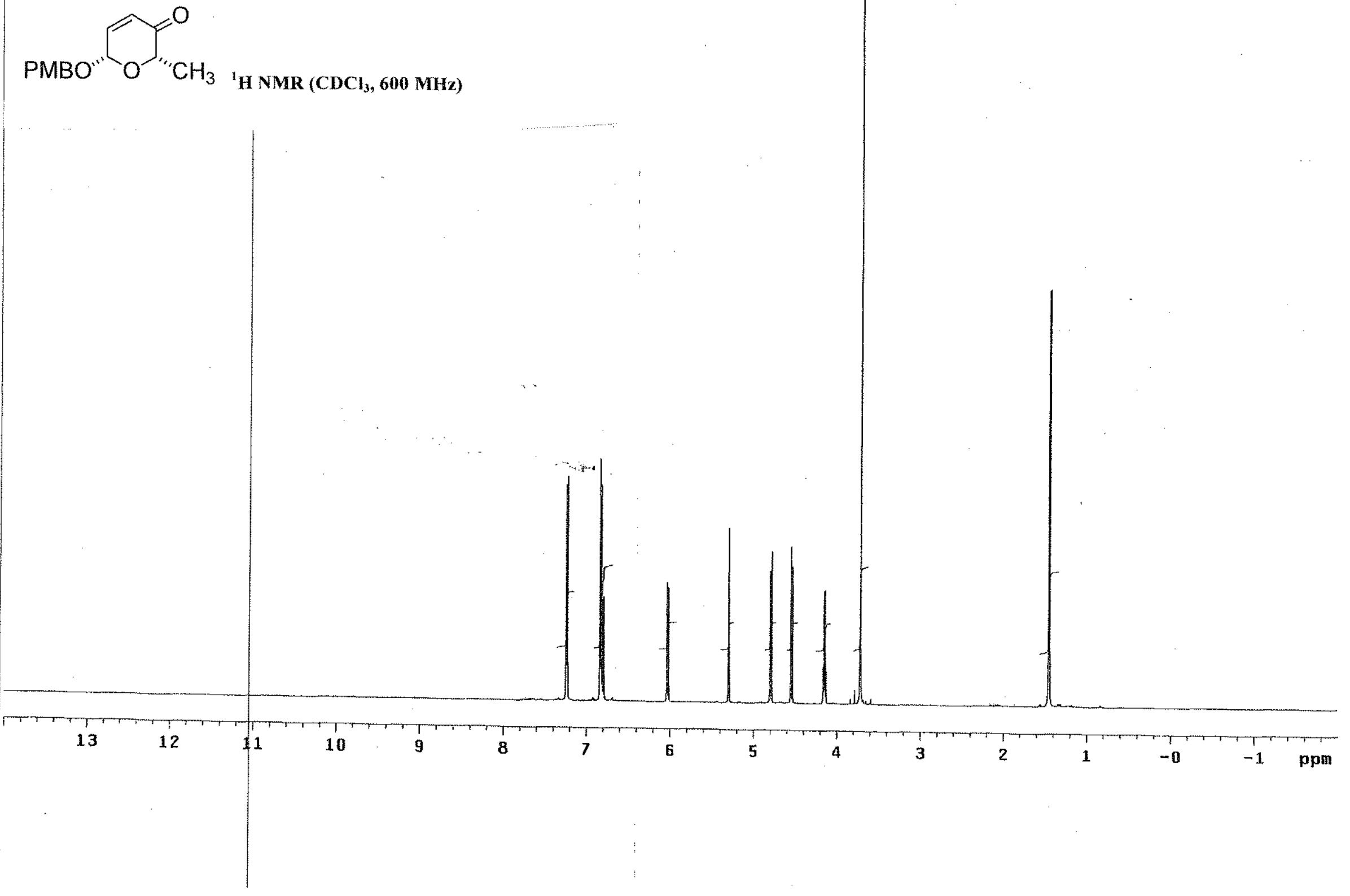
(2S,6S)-6-(4-methoxybenzyloxy)-2-methyl-2H-pyran-3(6H)-one (ent-9)

$\mathrm{PMBO}^{\prime \prime \prime} \mathrm{O}^{\prime \prime} \mathrm{CH}_{3}{ }^{13} \mathrm{C} \mathrm{NMR}\left(\mathrm{CDCl}_{3}, 150 \mathrm{MHz}\right)$

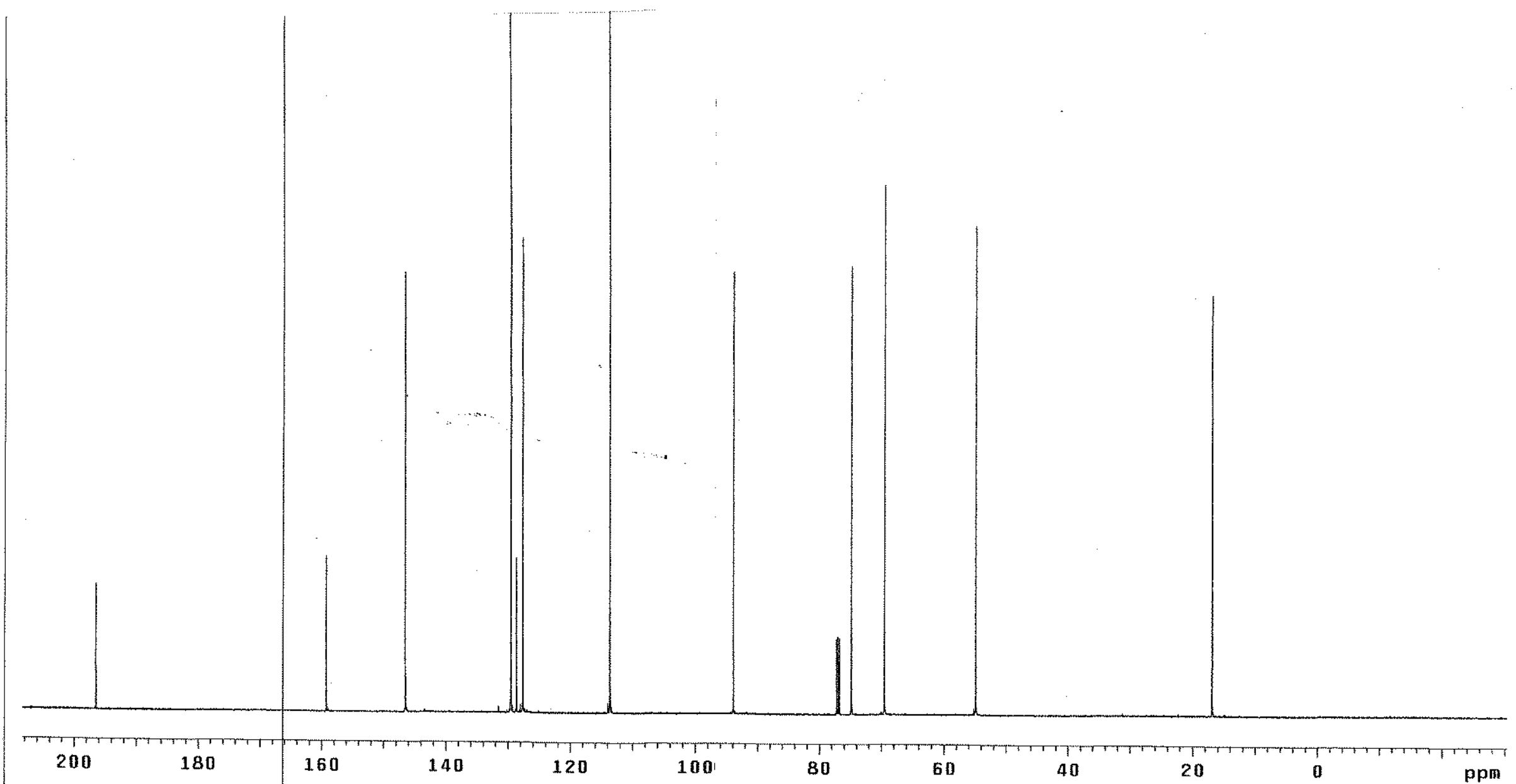




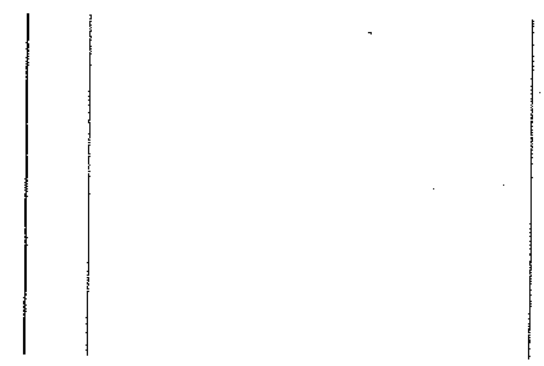

(2S,6S)-6-(4-methoxybenzyloxy)-3,6-dihydro-2-methyl-2H-pyran-3-ol (ent-10a/b):
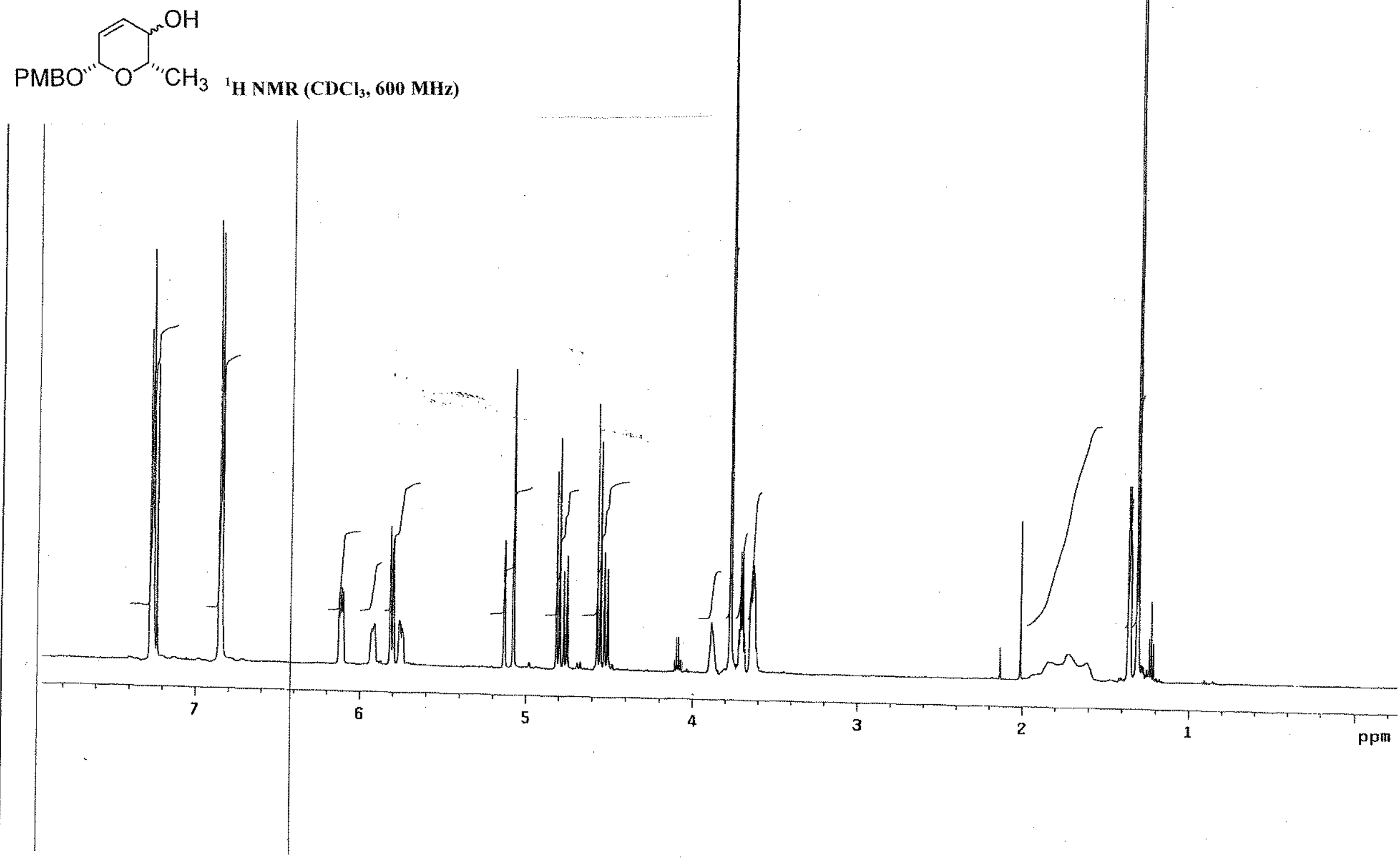


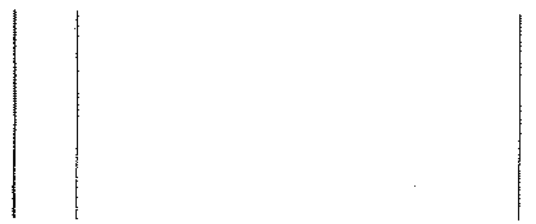

$(2 S, 6 S)-6-(4-m e t h o x y b e n z y l o x y)-3,6-d i h y d r o-2-m e t h y l-2 H$-pyran-3-ol $(e n t-10 a / b)$ :
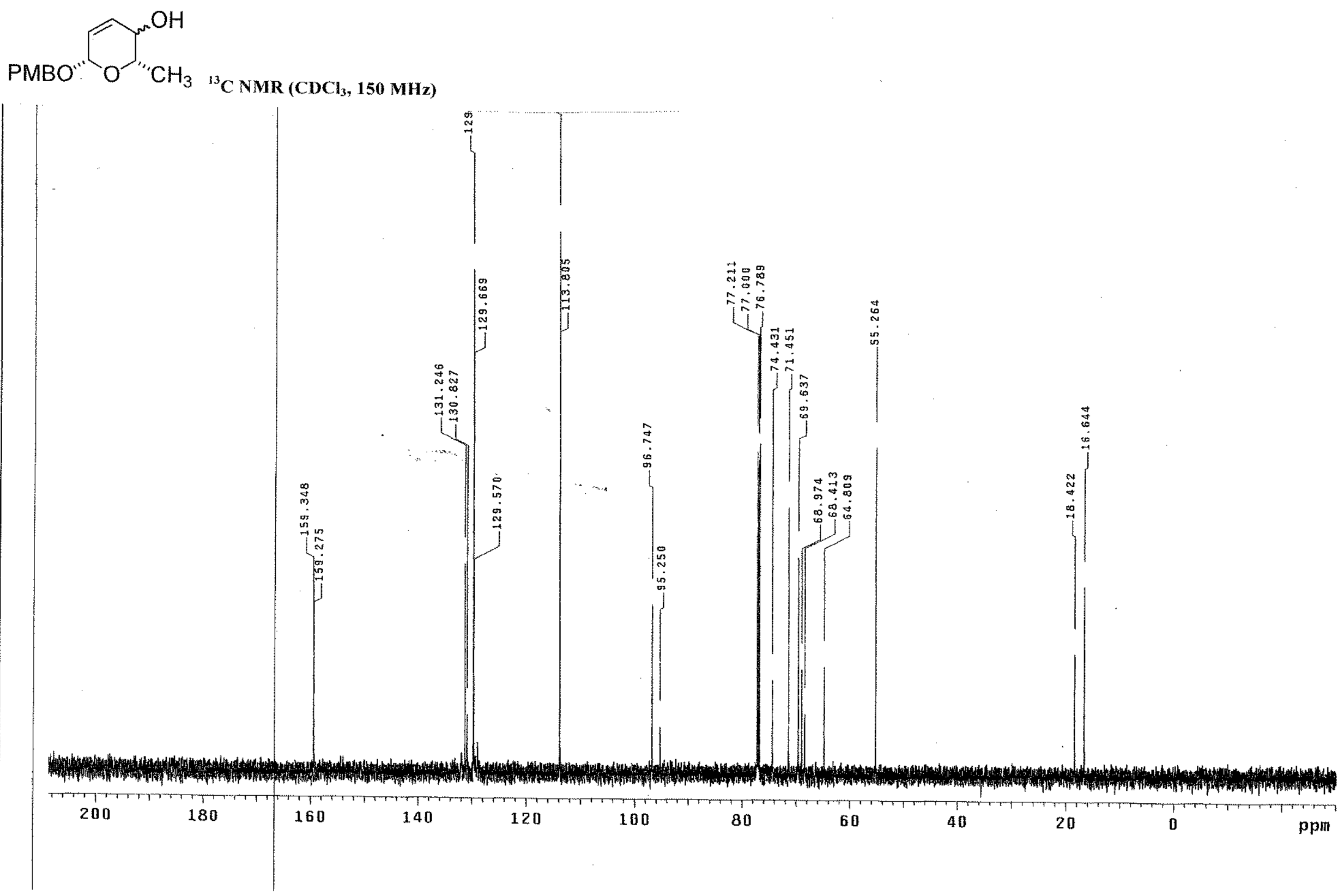


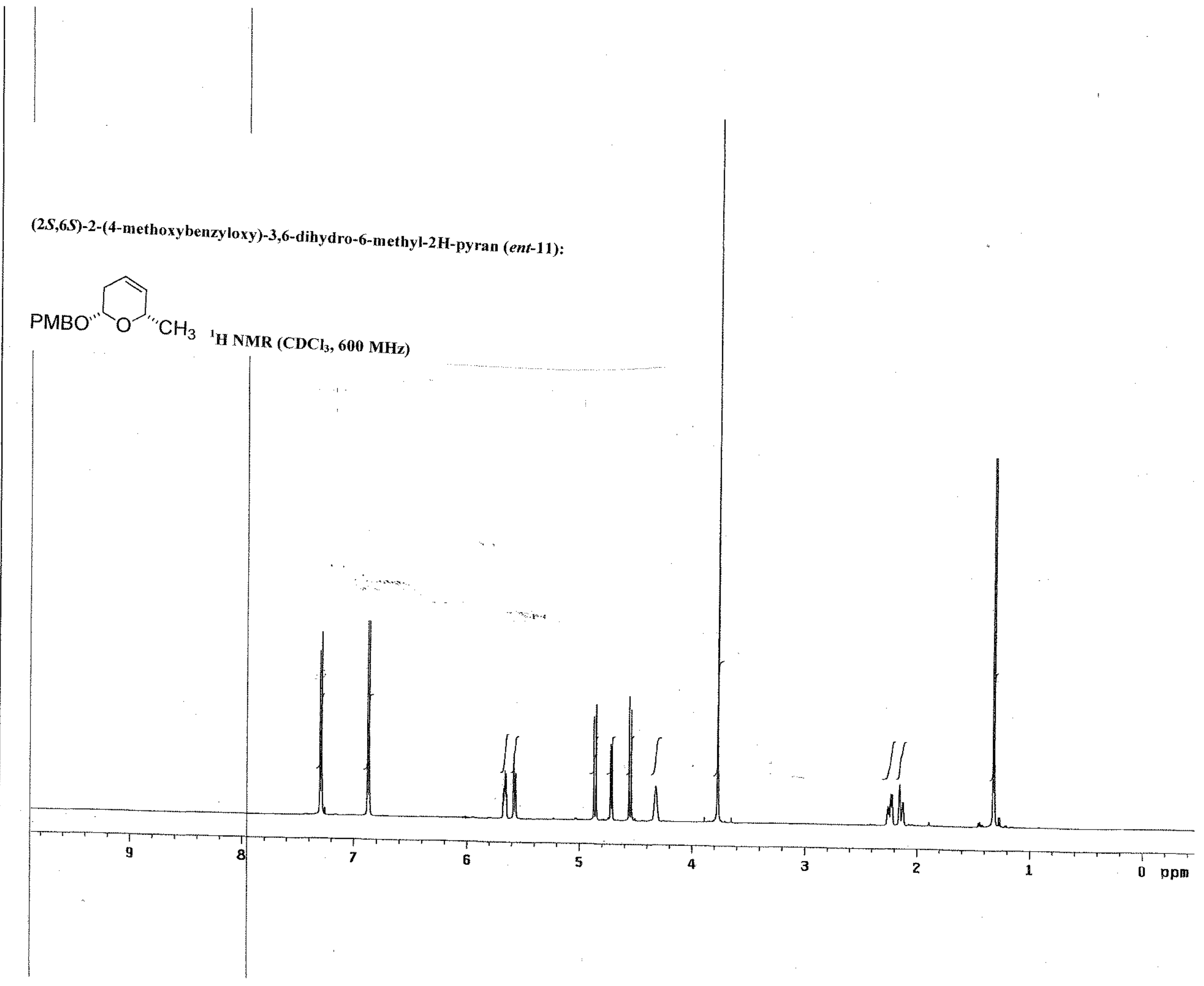


(2S,6S)-2-(4-methoxybenzyloxy)-3,6-dihydro-6-methyl-2H-pyran (ent-11):

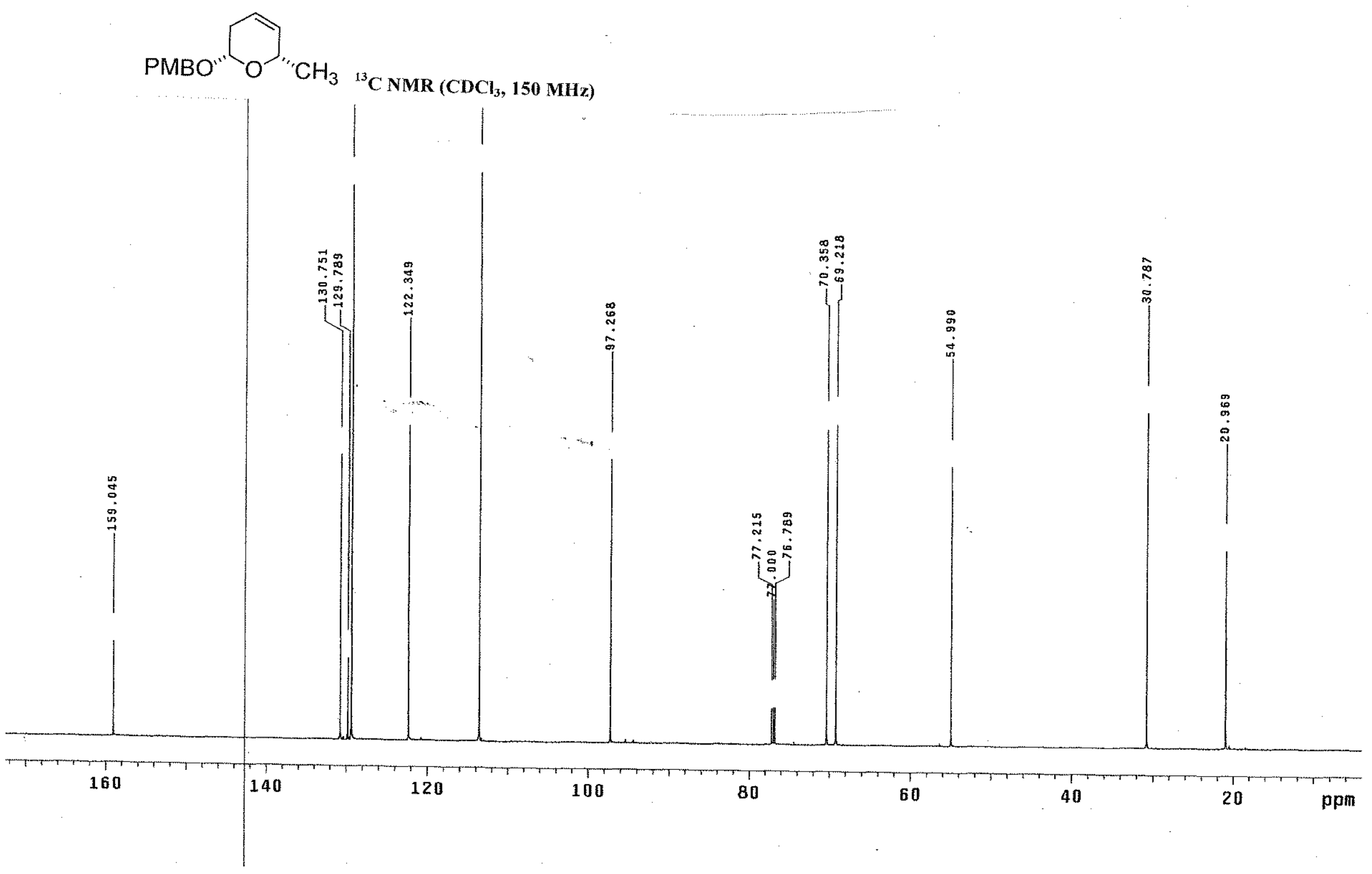




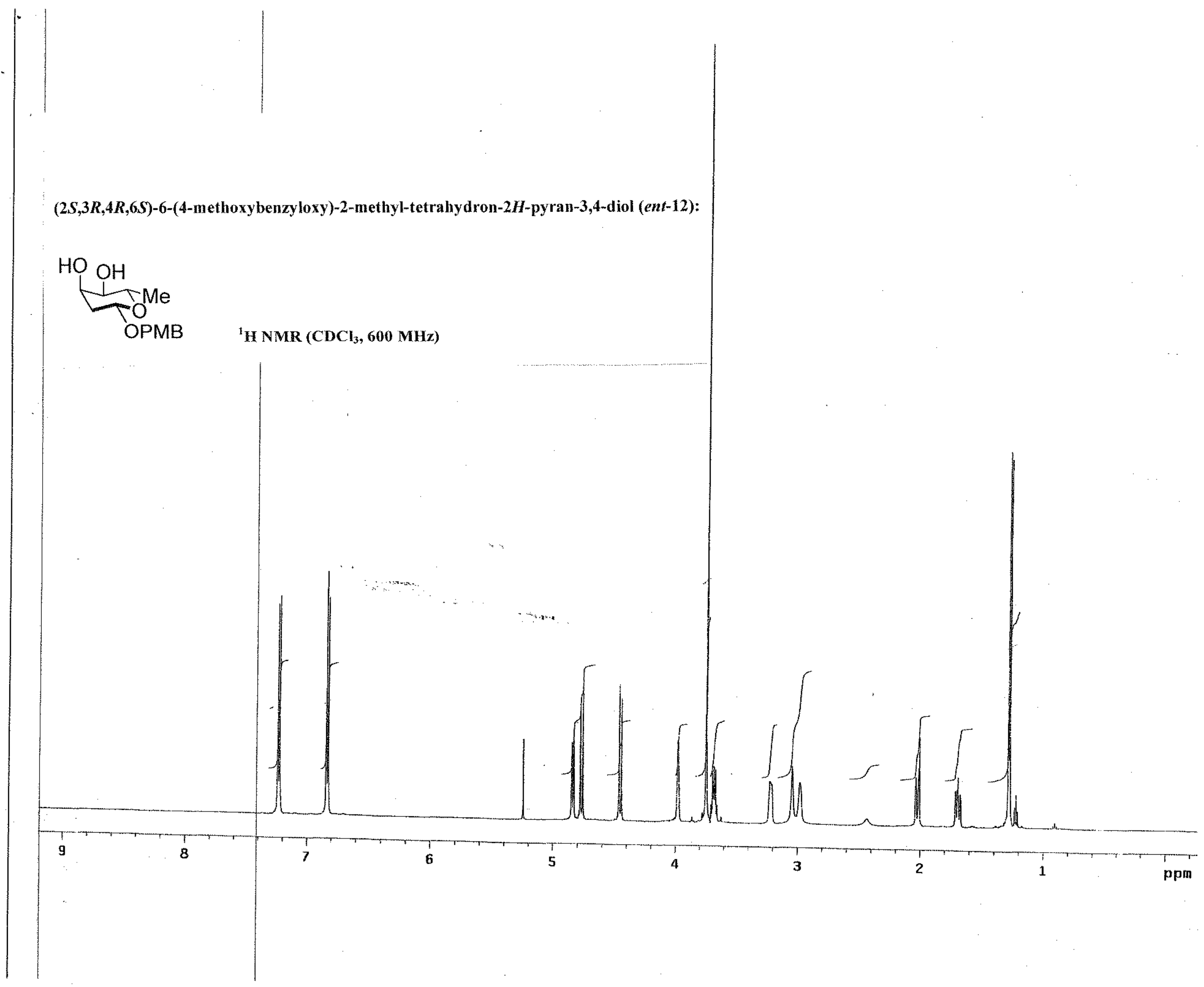


$(2 S, 3 R, 4 R, 6 S)-6-(4-m e t h o x y b e n z y l o x y)-2$-methyl-tetrahydron-2H-pyran-3,4-diol (ent-12):
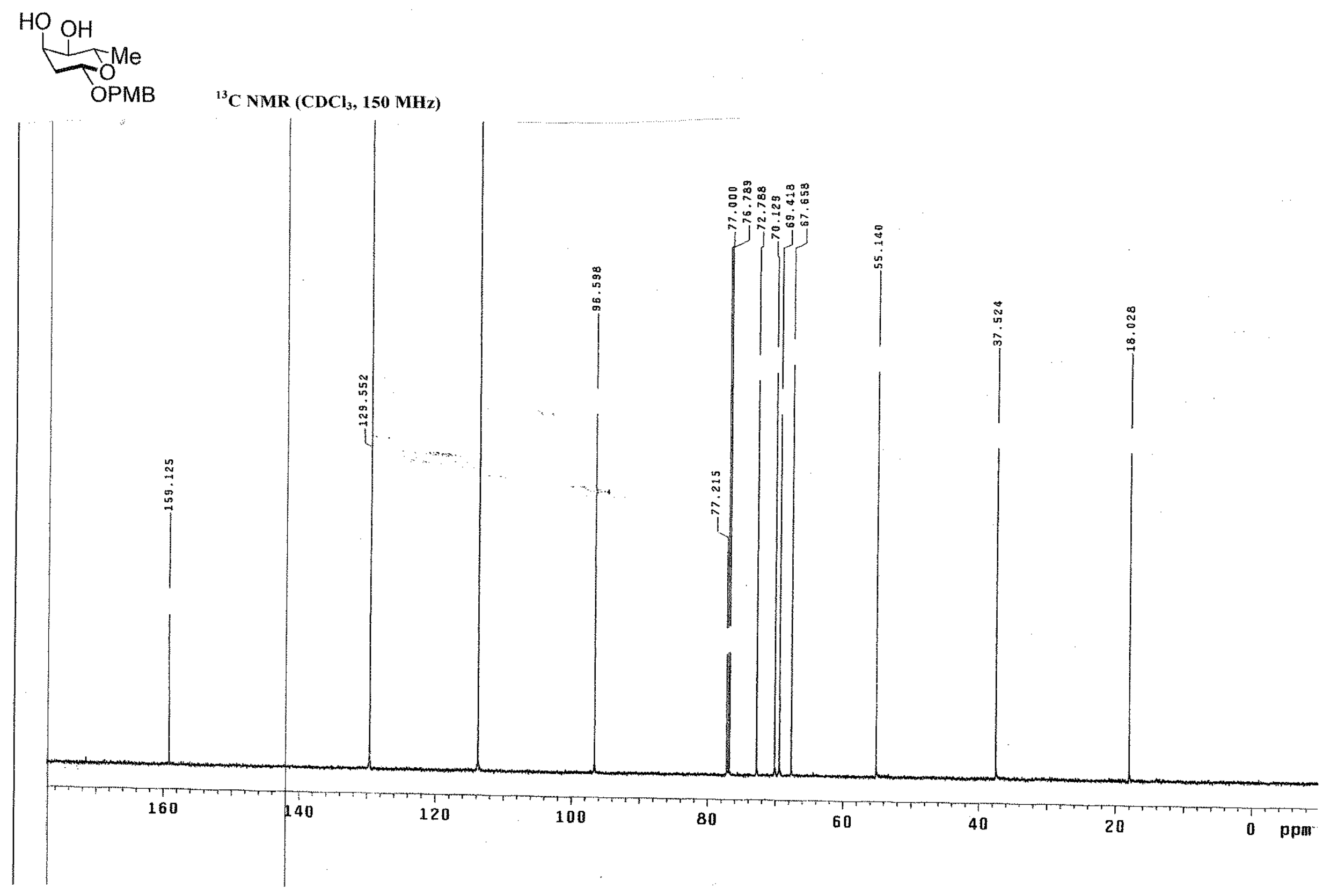
(2S,3S,4S,6S)-6-(4-methoxybenzyloxy)-tetrahydro-3-hydroxy-2-methyl-2H-pyran-4-yl 4-nitrobenzoate (ent-13):

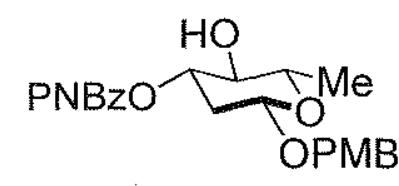

${ }^{1} \mathrm{H}$ NMR $\left(\mathrm{CDCl}_{3}, 600 \mathrm{MHz}\right)$

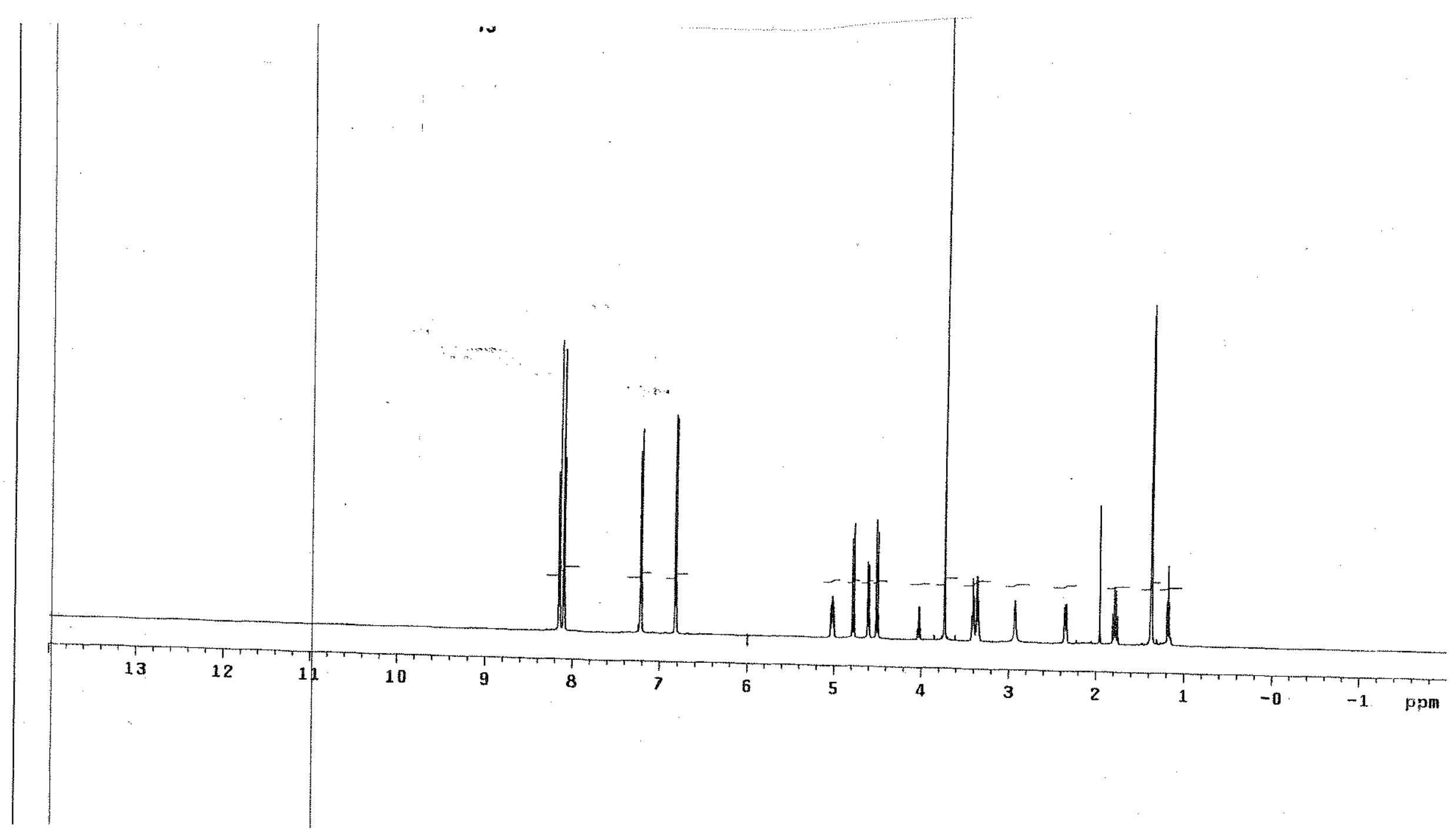




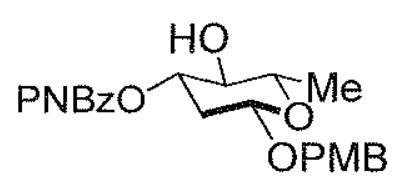

${ }^{13} \mathrm{C} \mathrm{NMR}\left(\mathrm{CDCl}_{3}, 150 \mathrm{MHz}\right)$

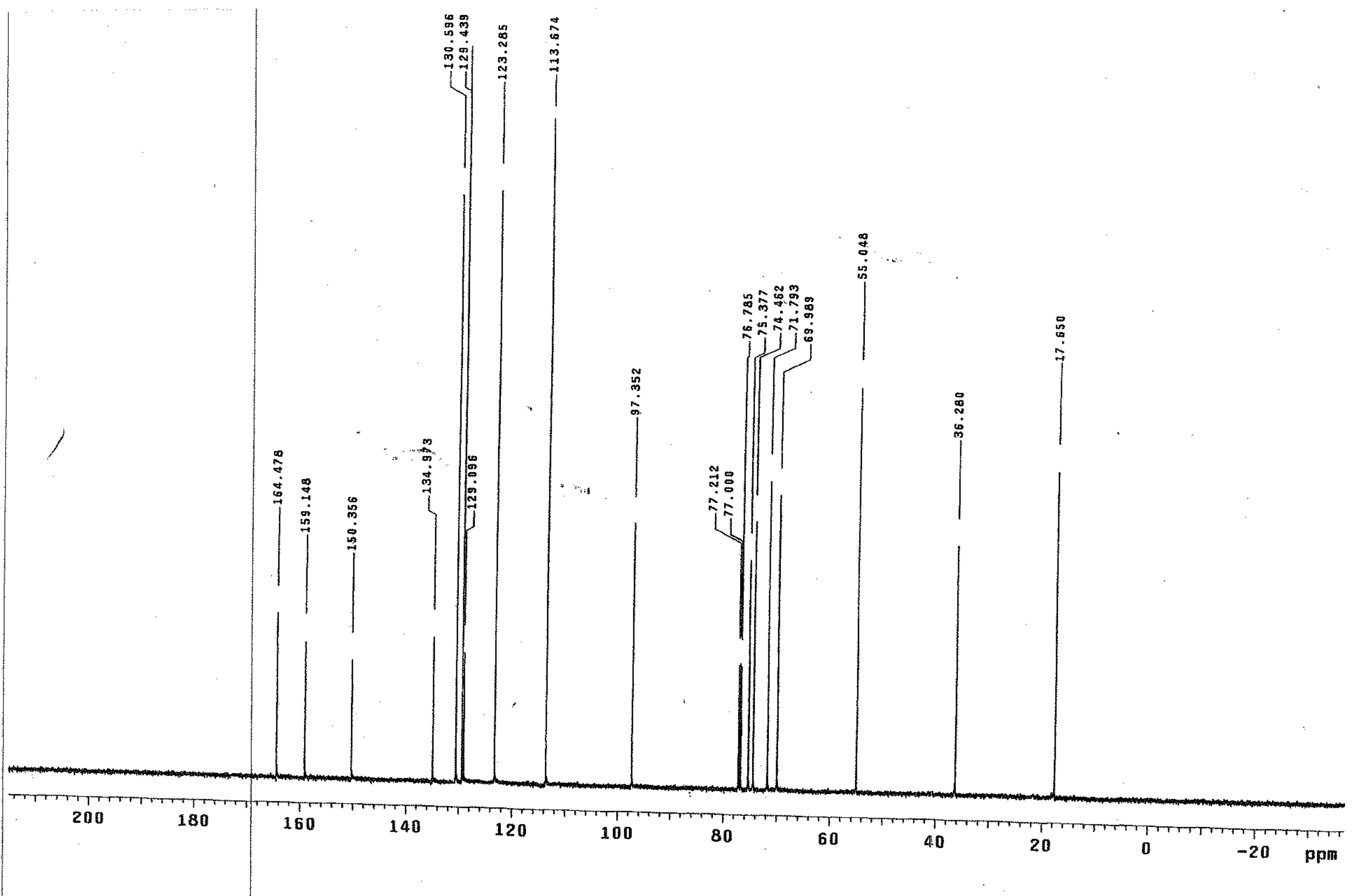


1

$(2 S, 3 S, 4 S, 6 S)-3-((2 R, 6 S)$-5,6-dihydro-6-methyl-5-0x0-2H-pyran-2-yloxy)-6-(4-methoxybenzyloxy)-tetrahydro-2-

methyl-2H-pyran-4-yl 4-nitrobenzoate (ent-14):

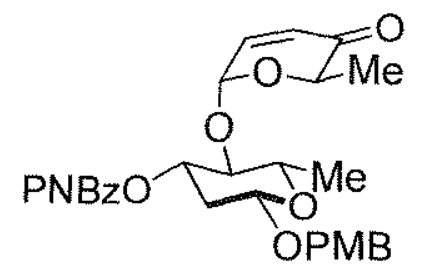

${ }^{\mathrm{I}} \mathrm{H} \mathrm{NMR}\left(\mathrm{CDCl}_{3}, 600 \mathrm{MHz}\right)$

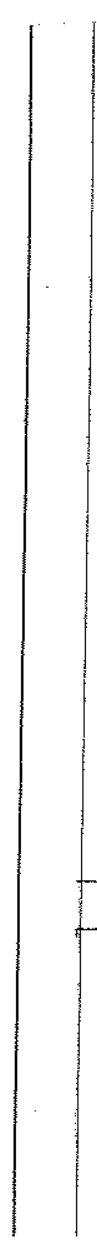
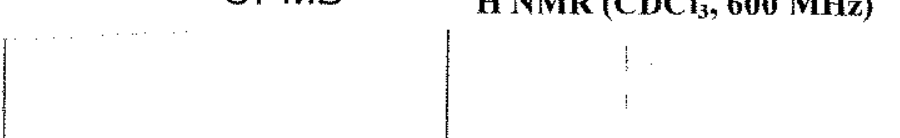
$(2 S, 3 S, 4 S, 6 S)-3-((2 R, 6 S)-5,6-d i h y d r o-6-m e t h y l-5-0 x 0-2 H-$ pyran-2-yloxy)-6-(4-methoxybenzyloxy)-tetrahydro-2-

methyl-2H-pyran-4-yl 4-nitrobenzoate (ent-14):

$\underbrace{\mathrm{O} M \mathrm{Me}}_{\mathrm{OPMB}}$

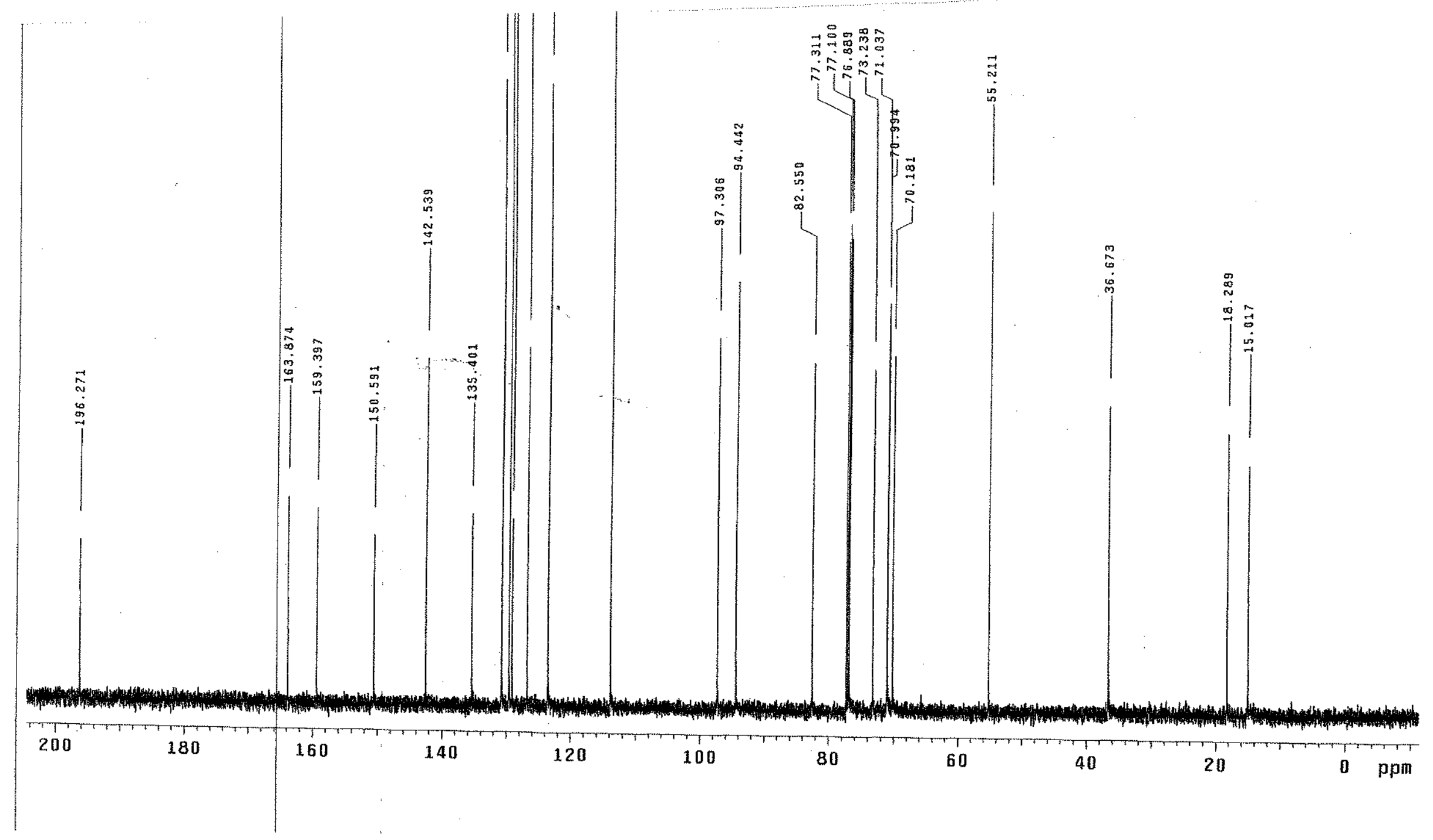


$(2 S, 3 S, 4 S, 6 S)-3-((2 S, 5 R, 6 R)-5,6-$ dihydro-5-hydroxy-6-methyl-2H-pyran-2-yloxy)-6-(4-methoxybenzyloxy)-

tetrahydro-2-methyl-2H-pyran-4-yl 4-nitrobenzoate (ent-15):
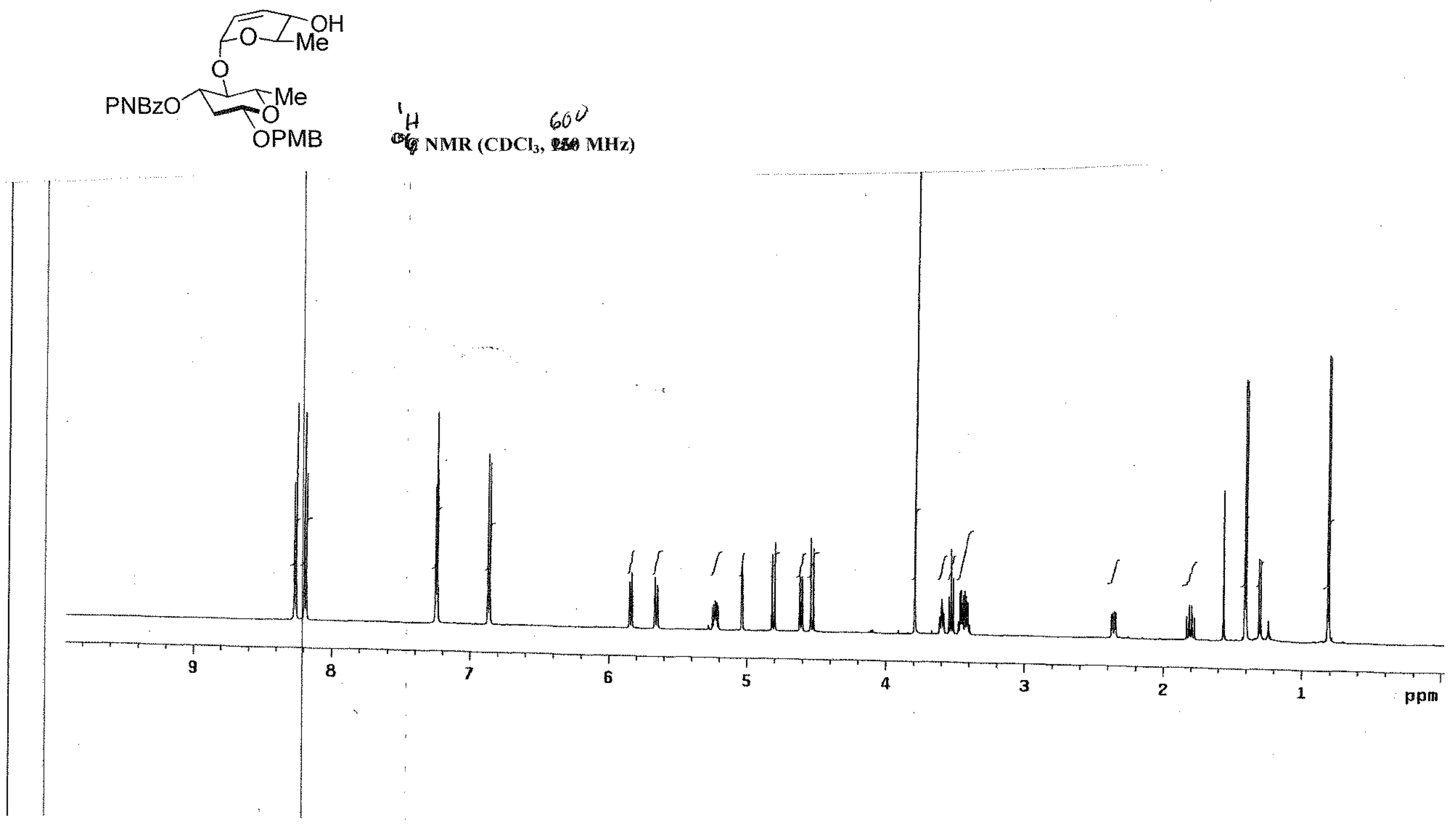


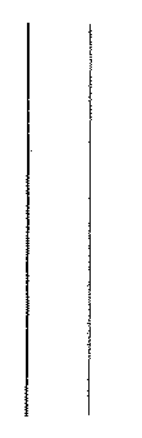

$(2 S, 3 S, 4 S, 6 S)-3-((2 S, 5 R, 6 R)-5,6$-dihyd ro-5-hydroxy-6-methyl-2H-pyran-2-yloxy)-6-(4-methoxybenzyloxy)tetrahydro-2-methyl-2H-pyran-4-yl 4-nitrobenzoate (ent-15):
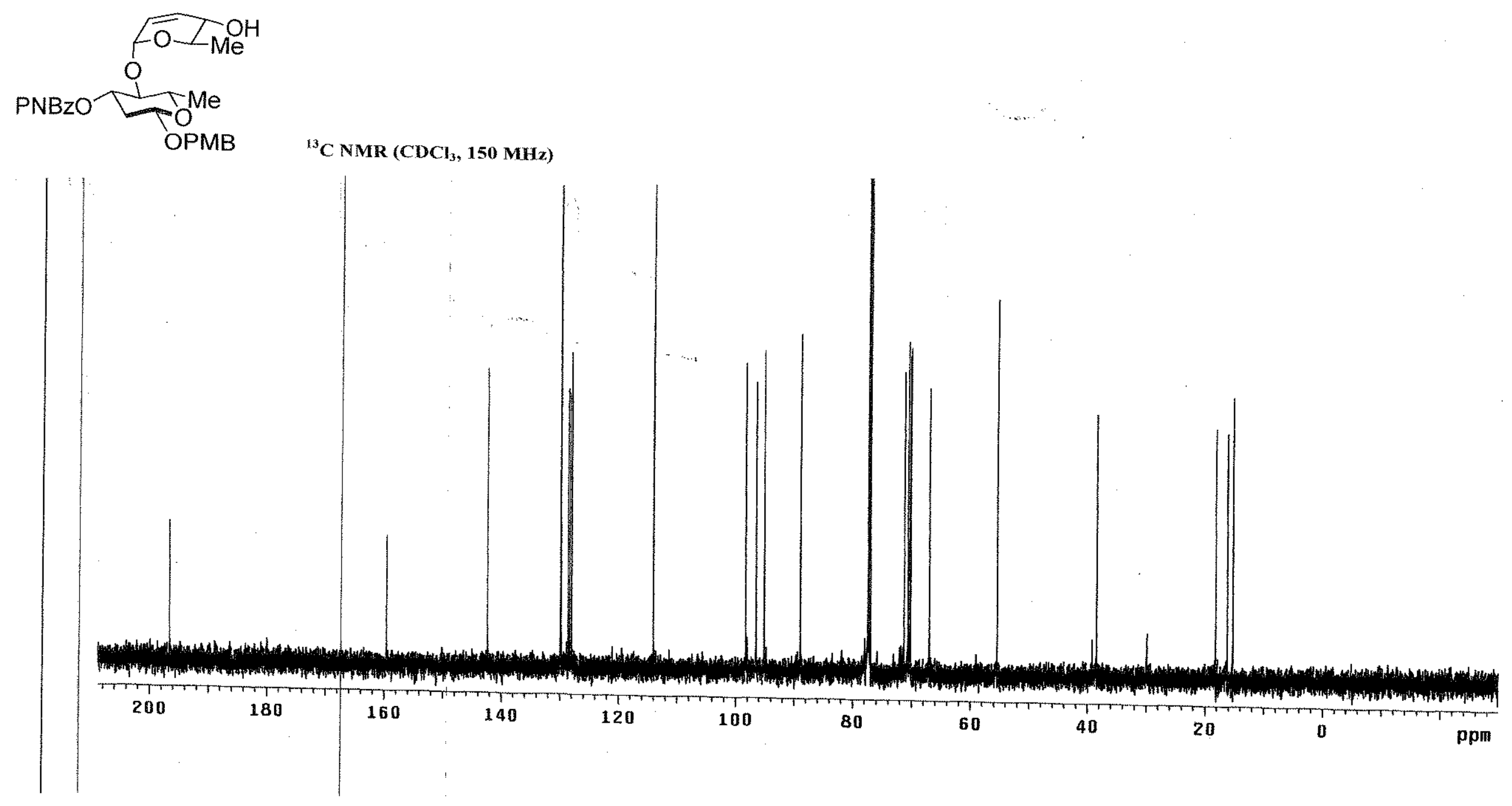


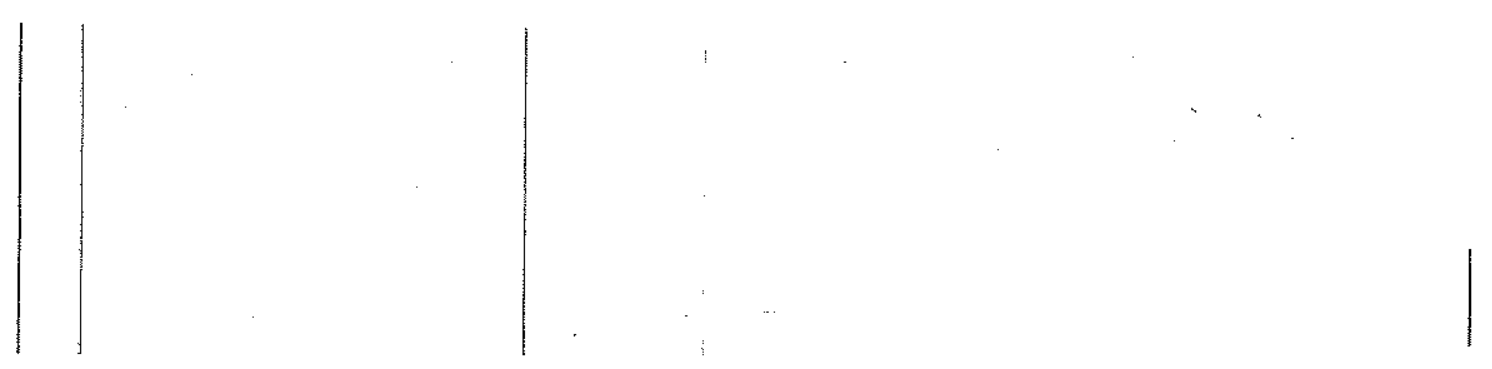

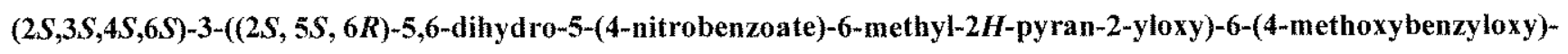

tetrahydro-2-methyl-2H-pyran-4-yl 4-nitrobenzoate $(e n t-16)$ :

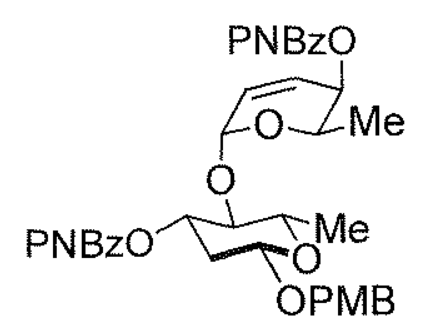

${ }^{1} \mathrm{H} \mathrm{NMR}\left(\mathrm{CDCl}_{3}, 600 \mathrm{MHz}\right)$

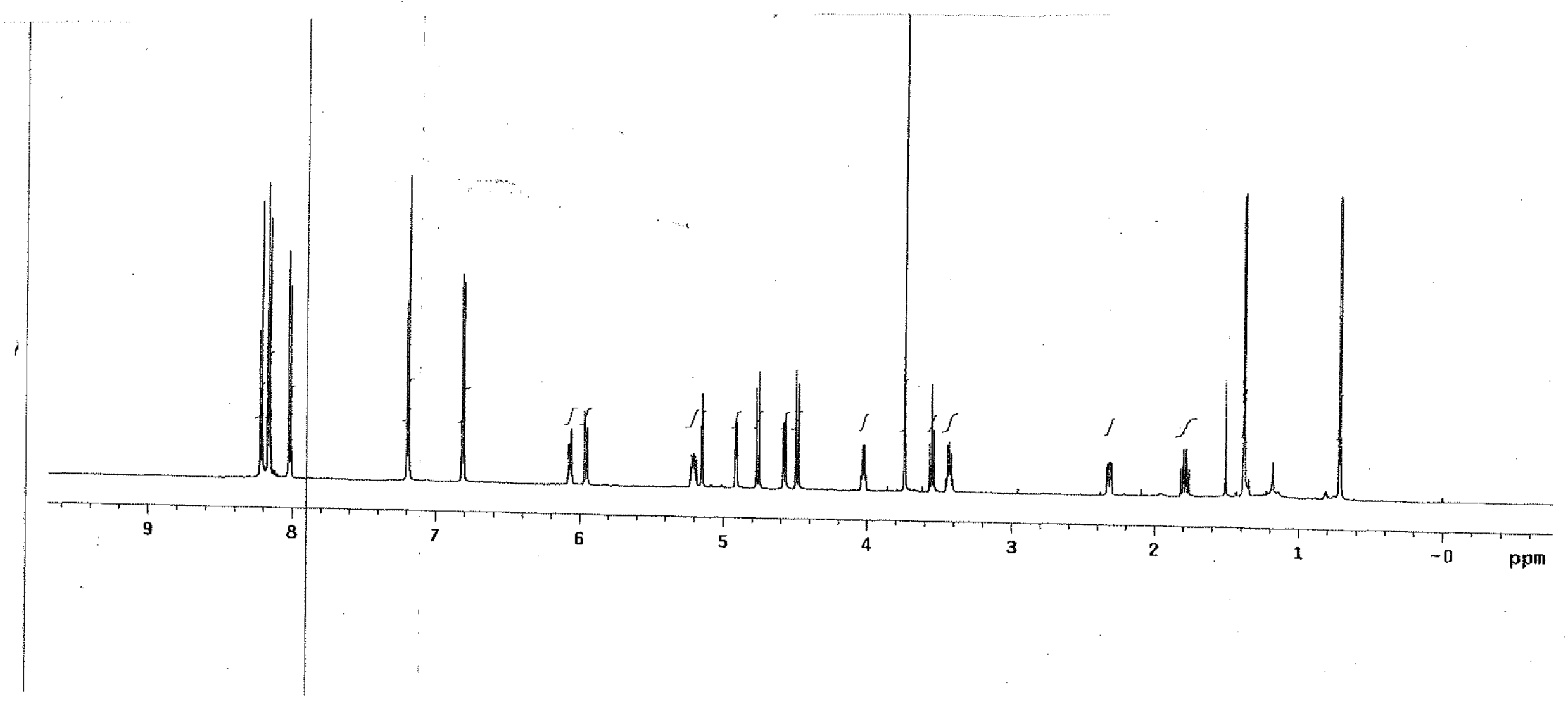


$(2 S, 3 S, 4 S, 6 S)-3-((2 S, 5 S, 6 R)-5,6$-dihydro-5-(4-nitrobenzoate)-6-methyl-2H-py ran-2-yloxy)-6-(4-methoxybenzyloxy)tetrahydro-2-methyl-2H-pyran-4-yl 4-nitrobenzoate (ent-16):

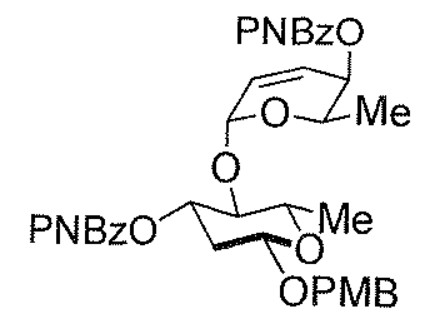

${ }^{13} \mathrm{C} \mathrm{NMR}\left(\mathrm{CDCl}_{3}, 150 \mathrm{MHz}\right)$
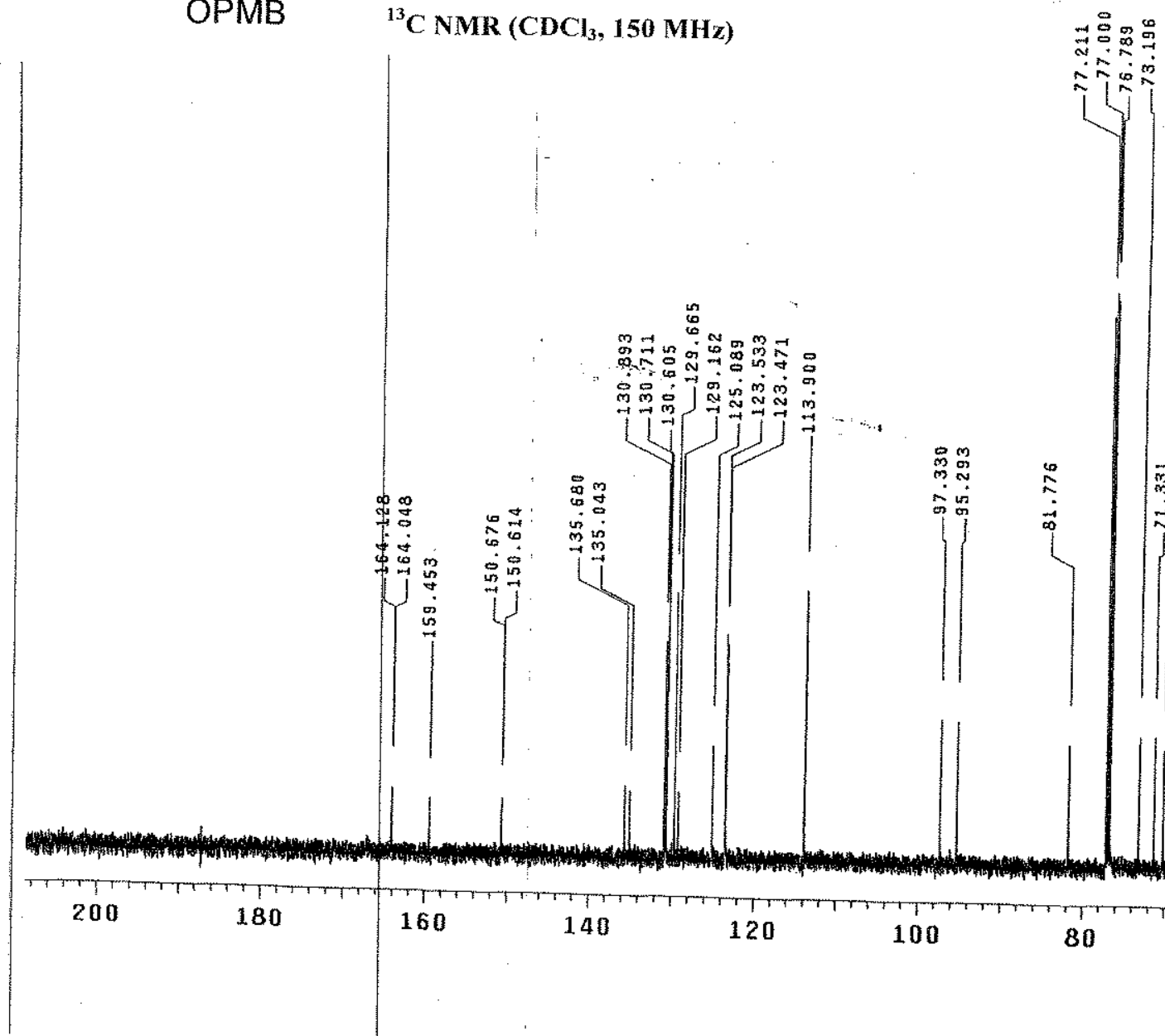

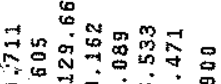

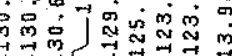
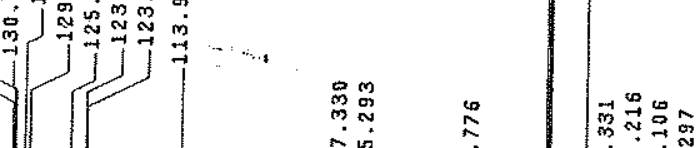

की

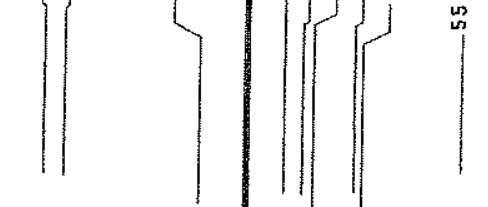


$(2 R, 3 R, 6 R)-6-((2 S, 3 S, 4 S, 6 S)-6-(4-m e t h o x y b e n z y l o x y)-4$-hydroxy-2-methyl-tetrahydro-2H-pyran-3-yloxy)-2-methyl-

3,6-dihydro-2H-pyran-3-ol (ent-17):

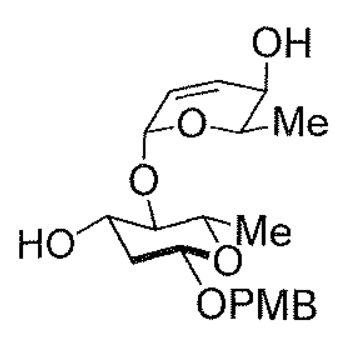

${ }^{1} \mathrm{H} \mathrm{NMR}\left(\mathrm{CDCl}_{3}, 600 \mathrm{MHz}\right)$

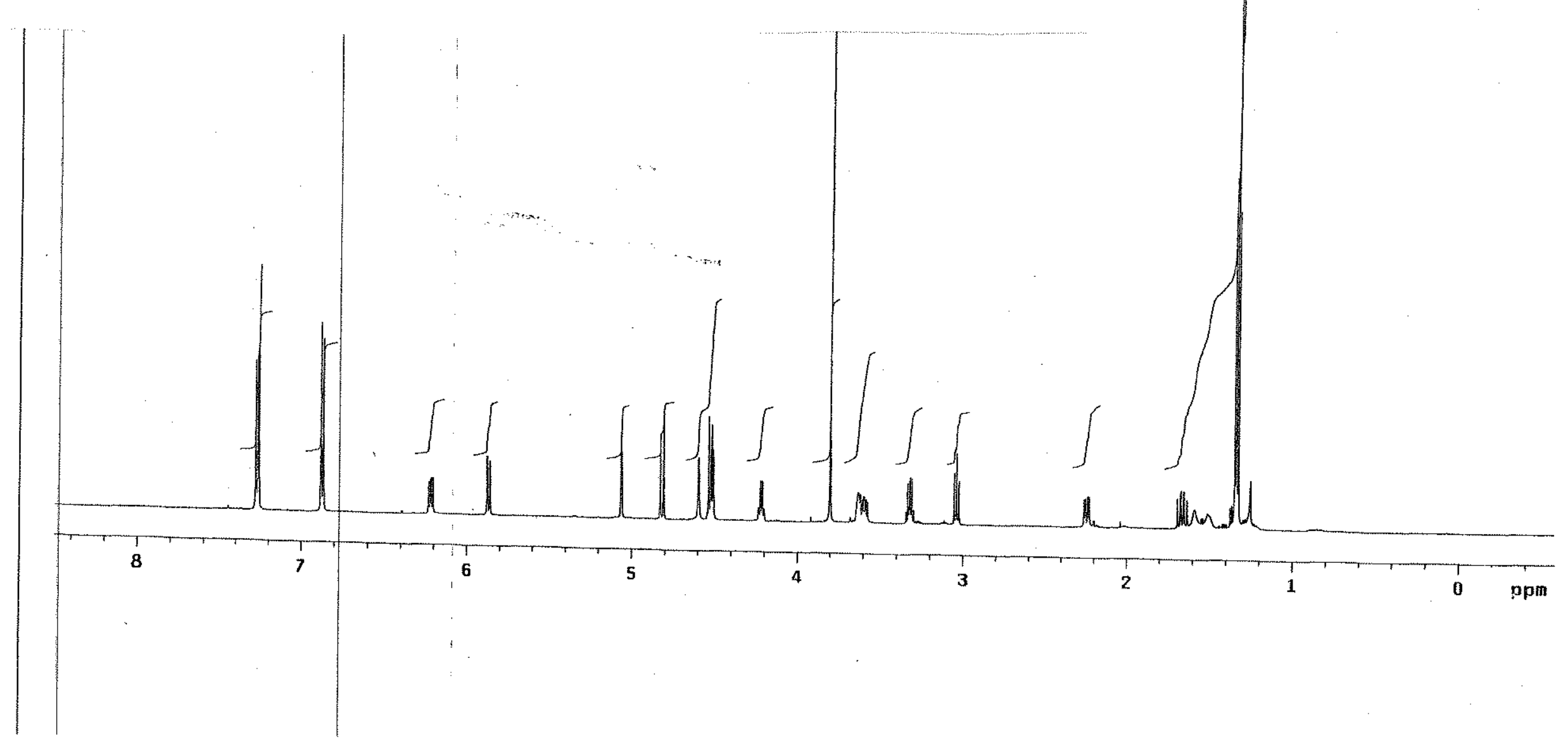


$(2 R, 3 R, 6 R)-6-((2 S, 3 S, 4 S, 6 S)-6-(4-m e t h o x y b e n z y l o x y)-4-h y d r o x y-2-m e t h y l-t e t r a h y d r o-2 H-p y r a n-3-y l o x y)-2-m e t h y l-$

3,6-dihydro-2H-py ran-3-ol $(e n t-17)$ :

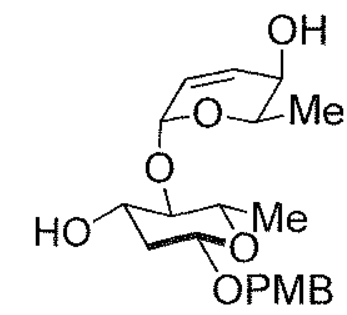

$$
\mathrm{OH}
$$
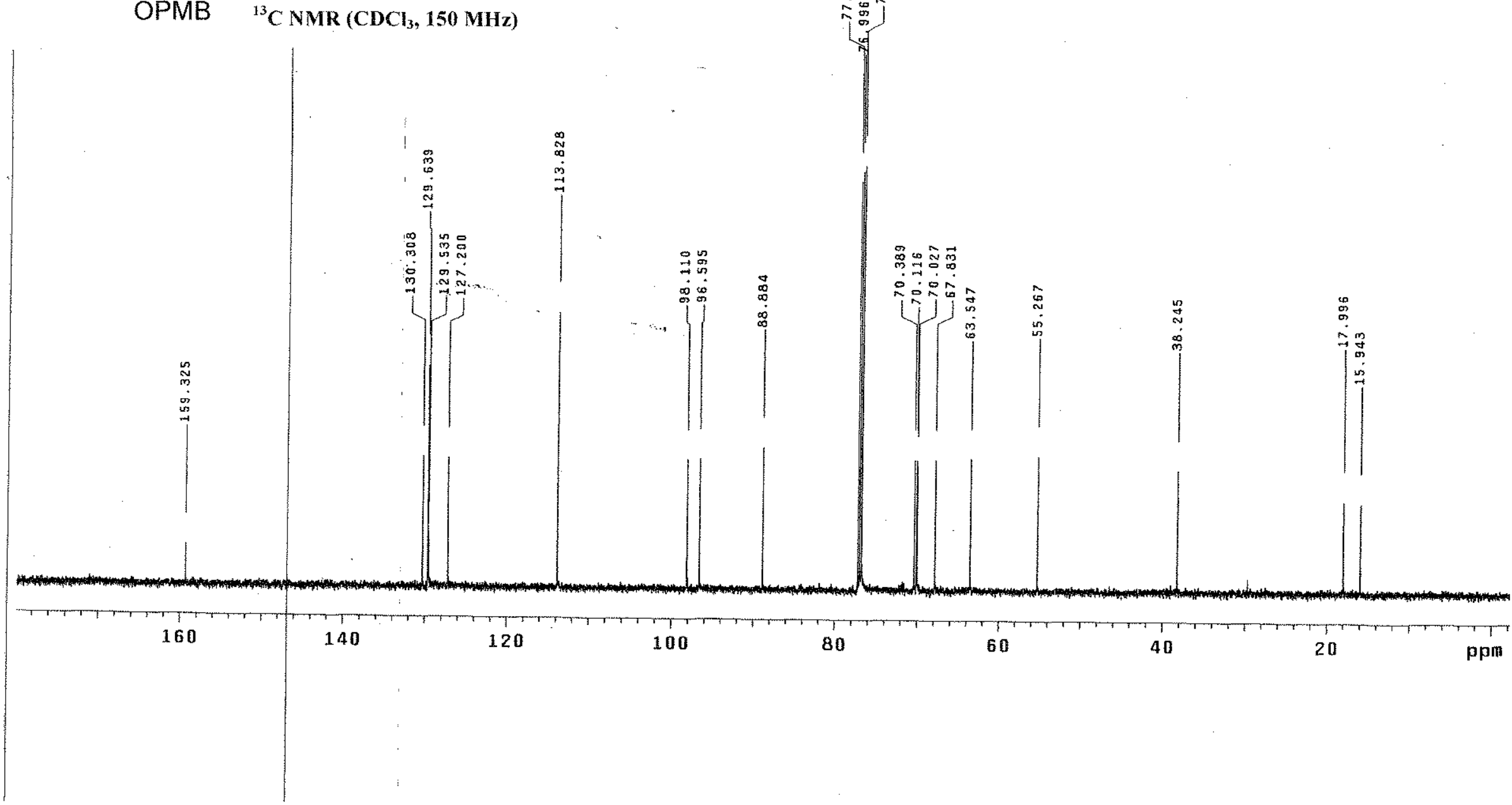
$(2 R, 3 R, 6 R)-6-((2 S, 3 S, 4 S, 6 S)-6-(4-m e t h o x y b e n z y l o x y)-4-h y d r o x y-2-m e t h y l-t e t r a h y d r o-2 H-p y r a n-3-y l o x y)-2-m e t h y l-$

tetrahydro-2H-pyran-3-ol (ent-18):
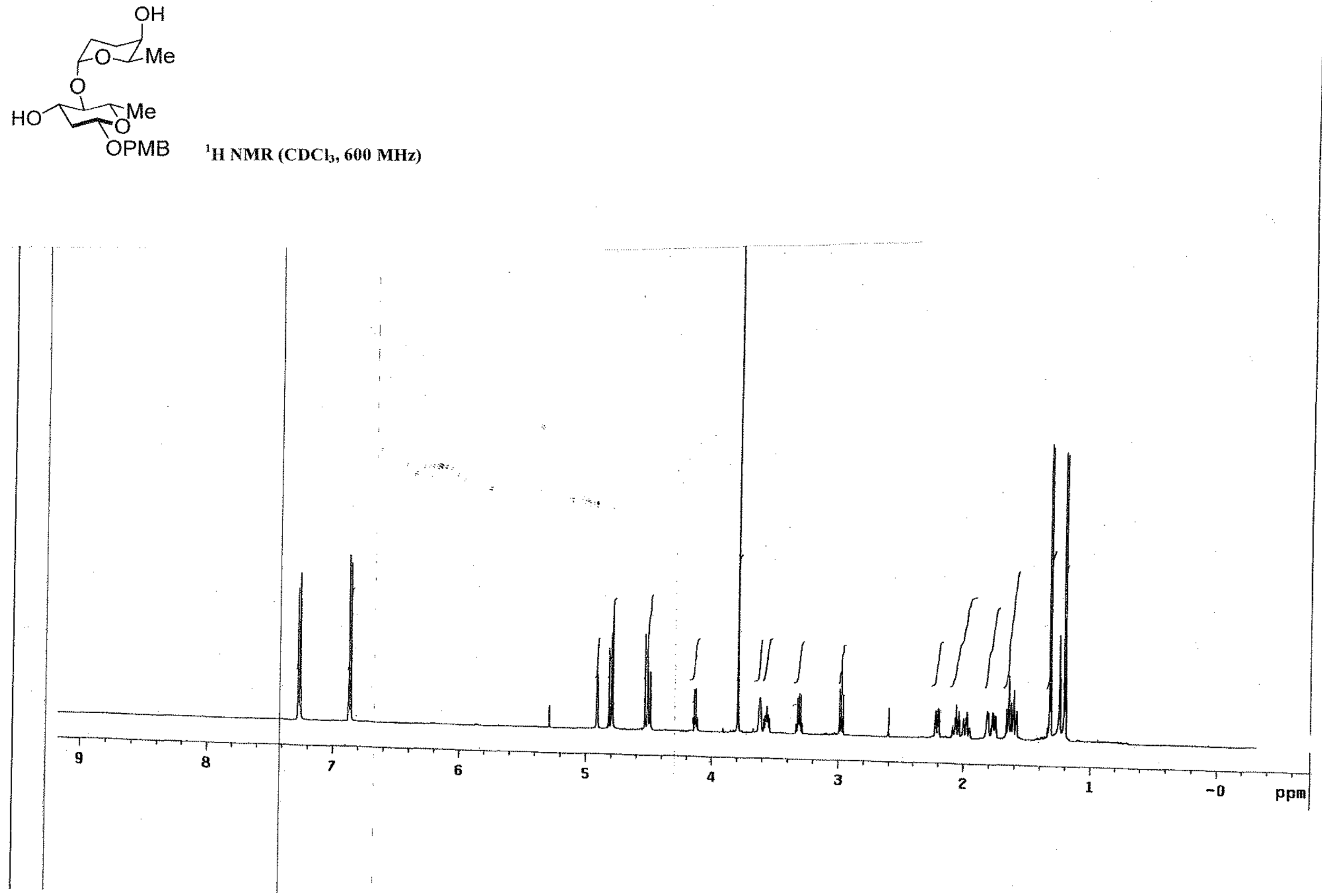
$(2 R, 3 R, 6 R)-6-((2 S, 3 S, 4 S, 6 S)-6-(4-m e t h o x y b e n z y l o x y)-4-h y d r o x y-2-m e t h y l-t e t r a h y d r o-2 H$-pyran-3-yloxy)-2-methyl-

tetrahydro-2H-pyran-3-ol (ent-18):

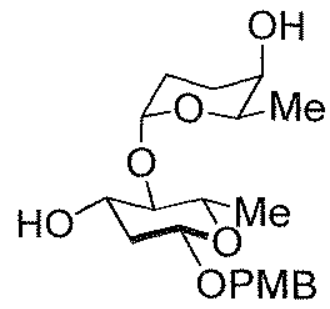

${ }^{13} \mathrm{C}$ NMR $\left(\mathrm{CDCl}_{3}, 150 \mathrm{MHz}\right)$

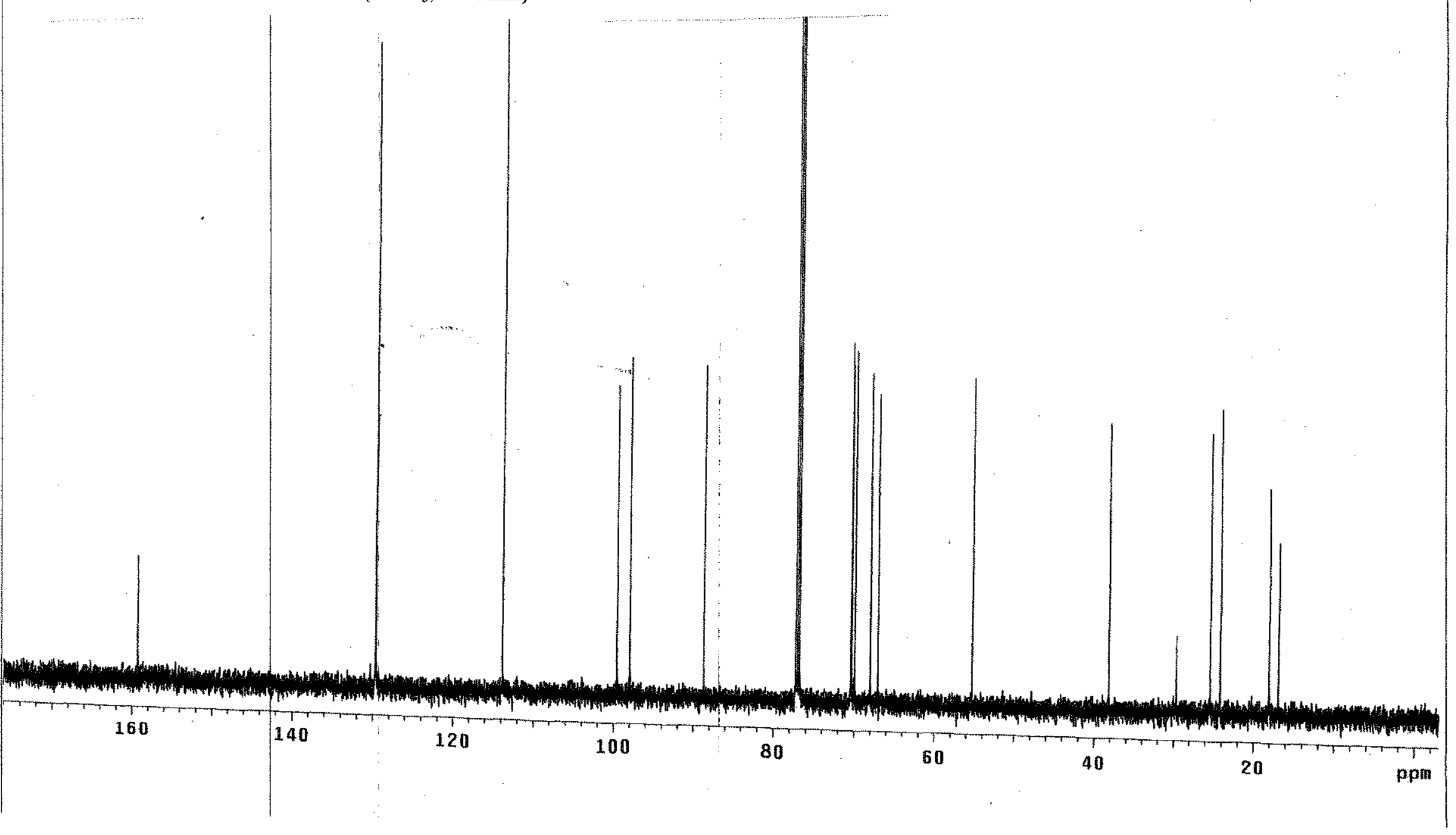


$(2 R, 6 S)-6-((2 R, 3 R, 6 R)-6-((2 S, 3 R, 4 S, 6 S)-6-(4-m e t h o x y b e n z y l o x y)-4-h y d r o x y-2-m e t h y l-t e t r a h y d r o-2 H-p y r a n-3-y l o x y)-2-$

methyl-tetrahydro-2H-pyran-3-yloxy)-2-methyl-2H-3(6H)-pyran-3-one (ent-19):

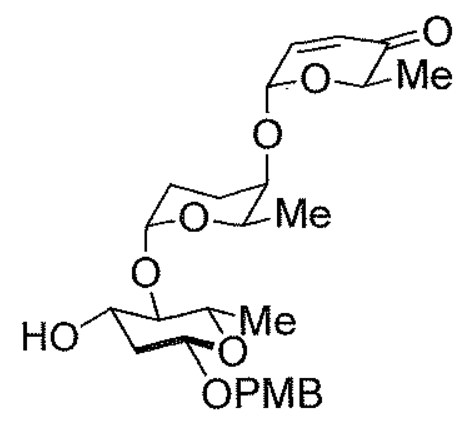

${ }^{1} \mathrm{H}$ NMR $\left(\mathrm{CDCl}_{3}, 600 \mathrm{MHz}\right)$

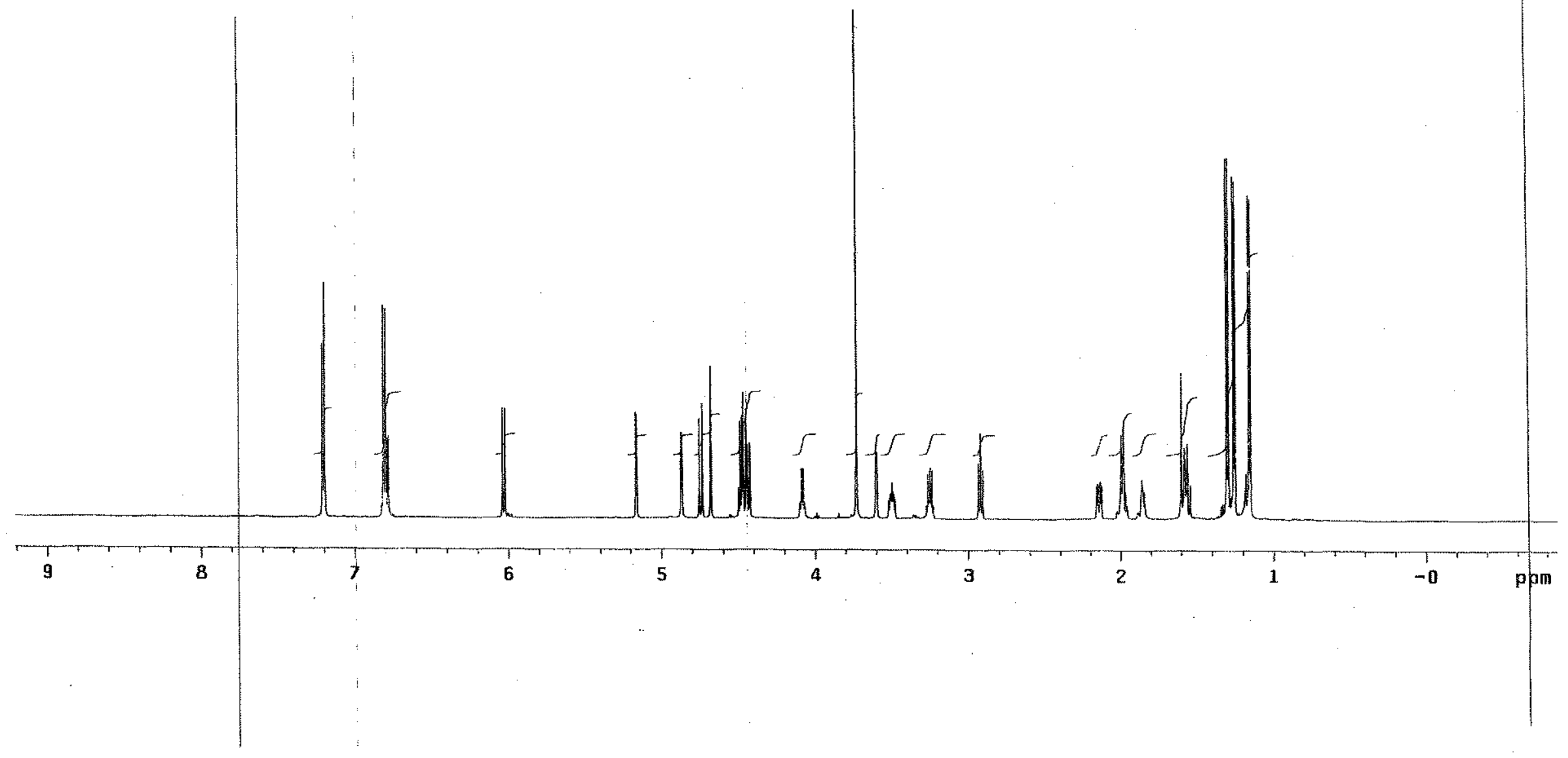


$(2 R, 6 S)-6-((2 R, 3 R, 6 R)-6-((2 S, 3 R, 4 S, 6 S)-6-(4-m e t h o x y b e n z y l o x y)-4-h y d r o x y-2-m e t h y l-t e t r a h y d r o-2 H-p y r a n-3-y l o x y)-2-$

methyl-tetrahydro-2H-pyran-3-yloxy)-2-methyl-2H-3(6H)-pyran-3-one (ent-19):

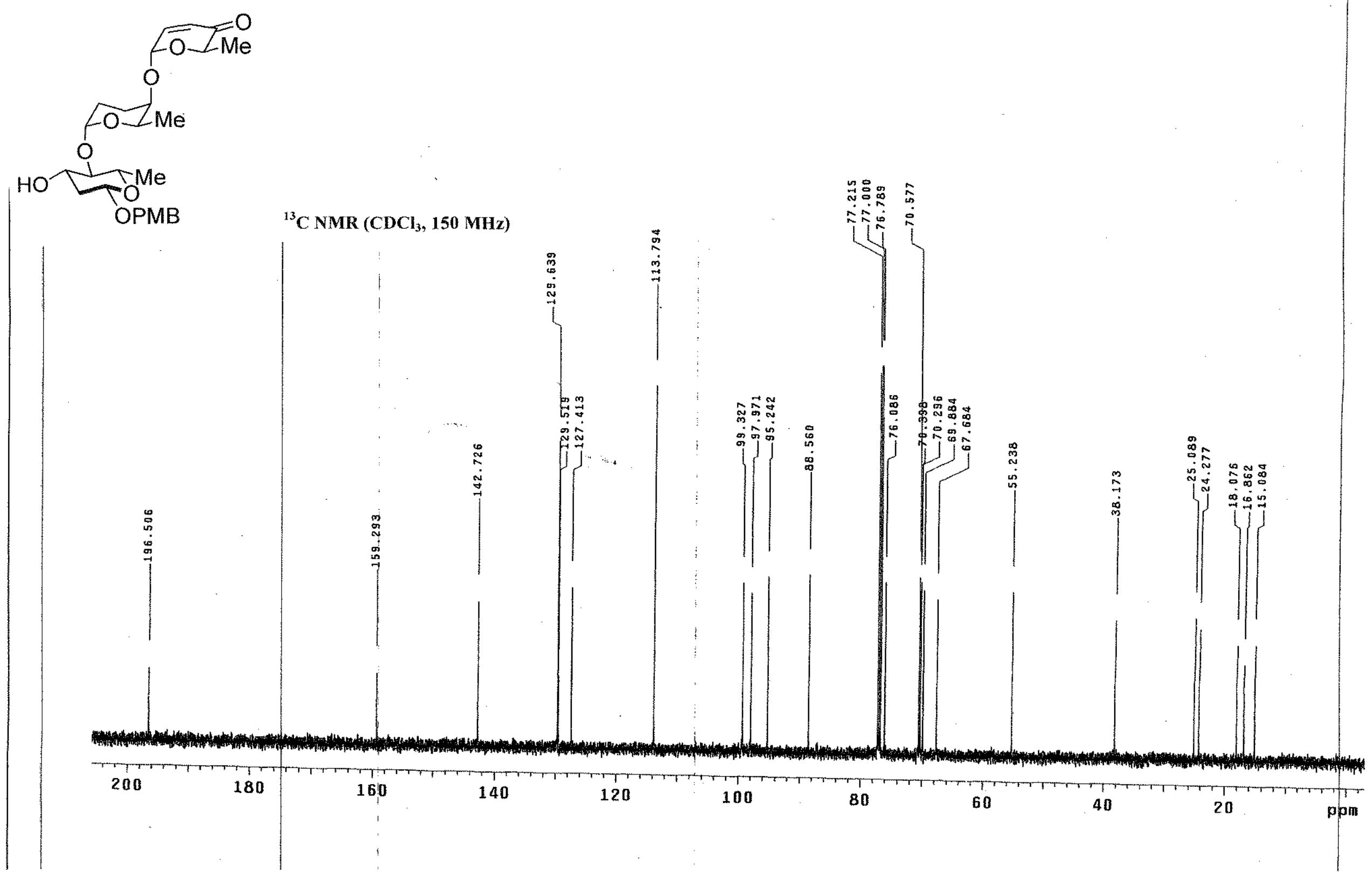


(6R)-6-pivaloyl-(2R)-2-methyl 2H-pyran-3(6H)-one (35)

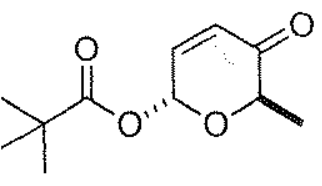

${ }^{1} \mathrm{H} \mathrm{NMR}\left(\mathrm{CDCl}_{3}, 600 \mathrm{MHz}\right)$

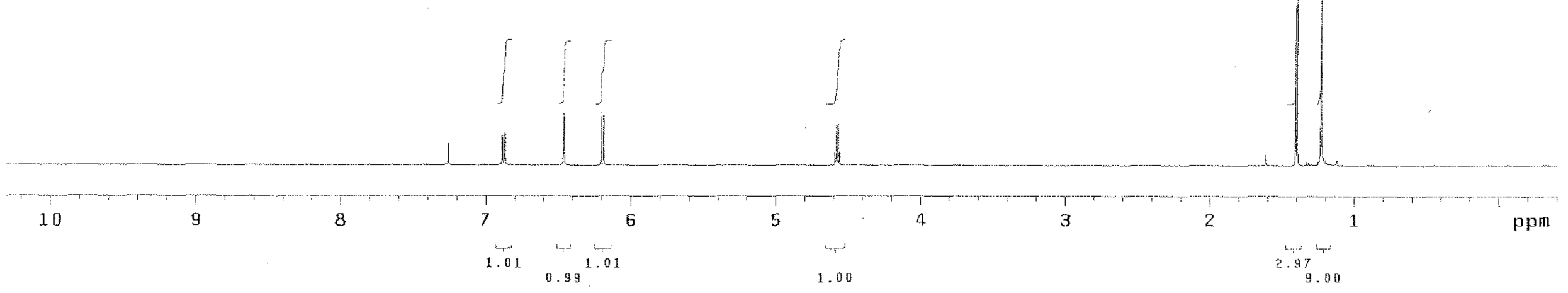


(6R)-6-pivaloyl-(2R)-2-methyl 2H-pyran-3(6H)-one (35)

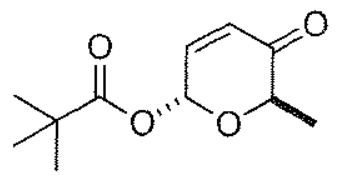

${ }^{13} \mathrm{C}$ NMR $\left(\mathrm{CDCl}_{3}, 150 \mathrm{MHz}\right)$

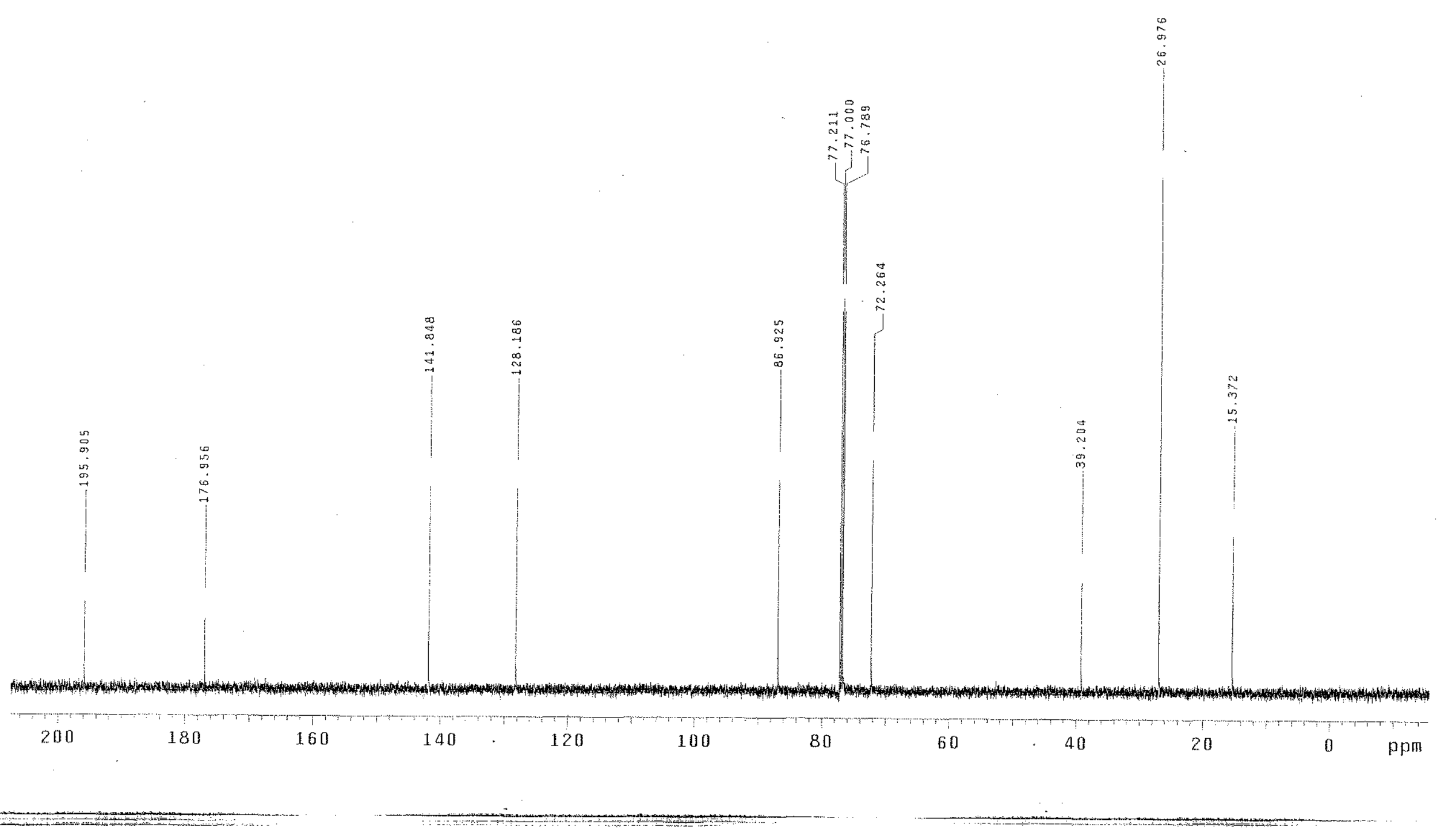


$((2 R, 5 S, 6 R)-5,6$-dihyd ro-5-hydroxy-6-methyl-2H-pyran-2-yl pivalate (36).

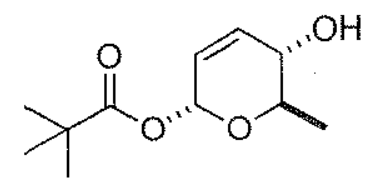

${ }^{\prime} \mathrm{H}$ NMR $\left(\mathrm{CDCl}_{3}, 600 \mathrm{MHz}\right)$

With $9594.6 \mathrm{~Hz}$

6 Sepetitions
OBSERVE HI, $599.6670078 \mathrm{MHZ}$

DATA PROCESSING
Line broadening $0.2 \mathrm{~Hz}$

FT size 131072
Total tiat 0 min, 30 sec 


\section{$((2 R, 5 S, 6 R)-5,6$-dihydro-5-hydroxy-6-methyl-2H-pyran-2-yl pivalate (36).}

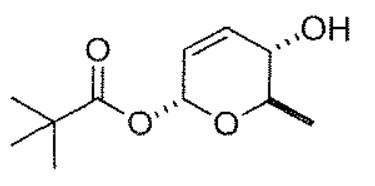

DECOUPLE HI, 599.6700024 MHZ

Power $40 \mathrm{~dB}$

WALTZ - I 6 modulated

DATA PROCESSTNE

Line broadening $1.0 \mathrm{~Hz}$

fotal time $32 \mathrm{~min}, 34 \mathrm{sec}$

\section{NMR $\left(\mathrm{CDCl}_{3}, 150 \mathrm{MHz}\right)$}

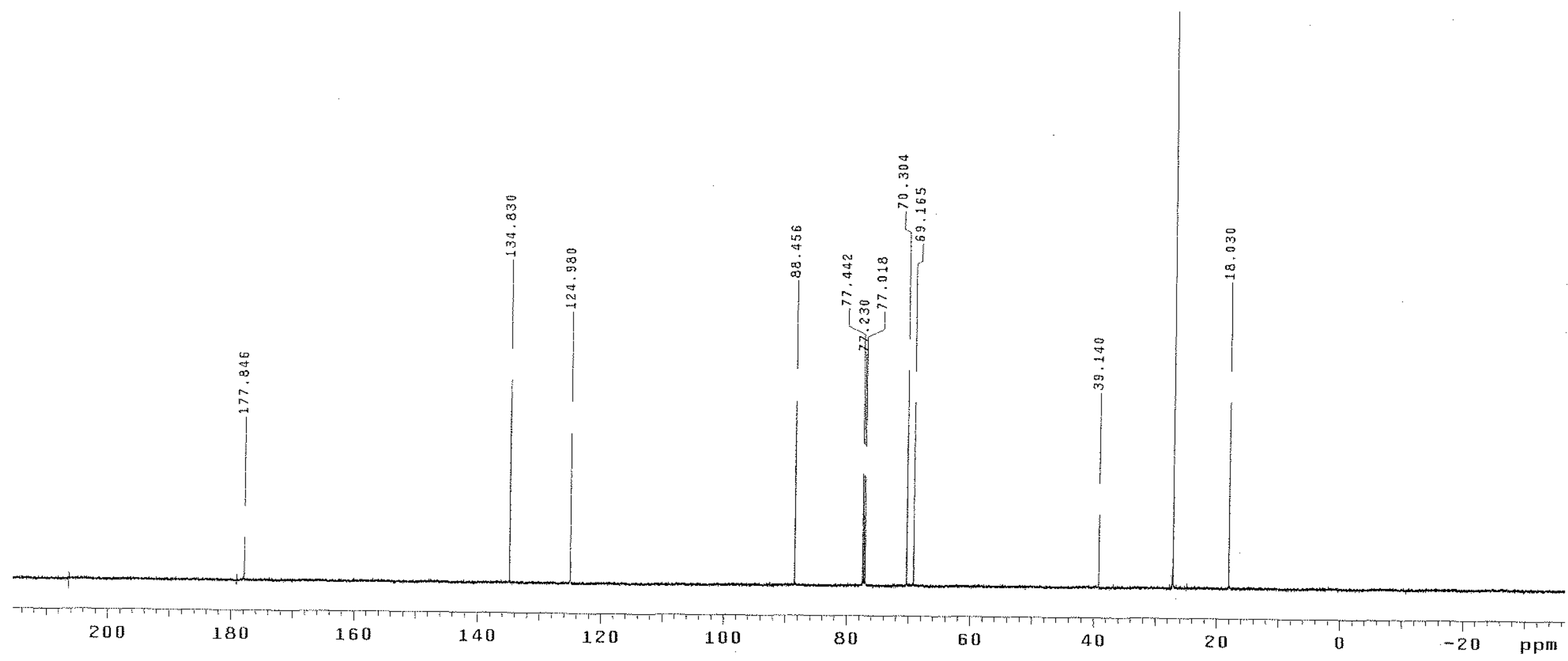




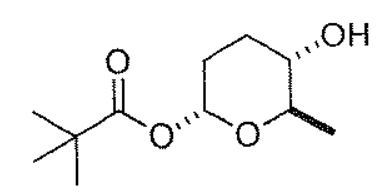

${ }^{1} \mathrm{H}$ NMR $\left(\mathrm{CDCl}_{3}, 600 \mathrm{MHz}\right)$

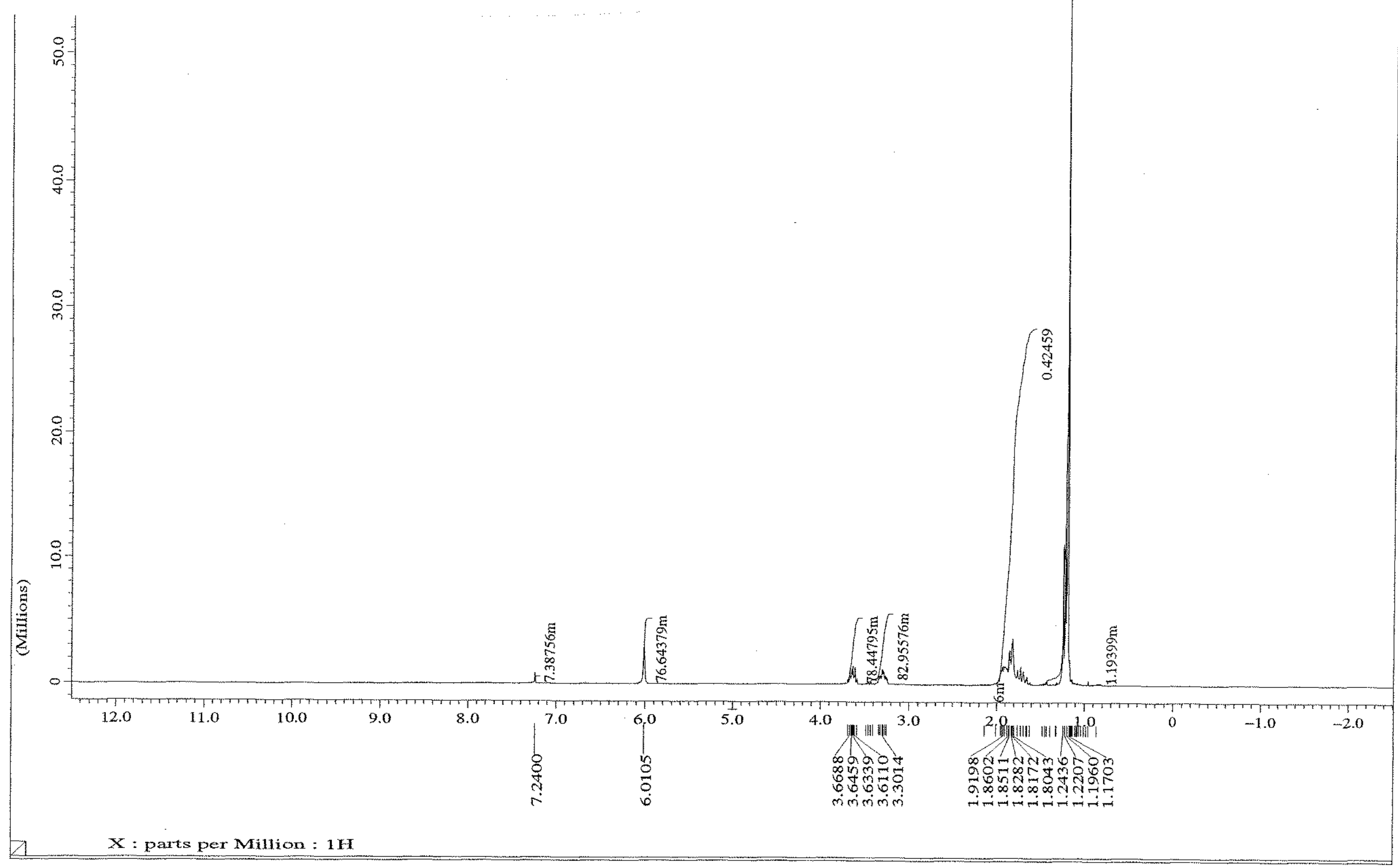




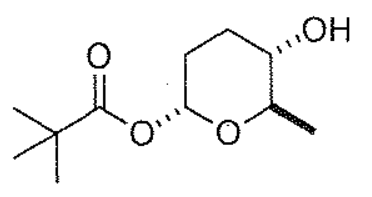

${ }^{13} \mathrm{C} \mathrm{NMR}\left(\mathrm{CDCl}_{3}, 150 \mathrm{MHz}\right)$

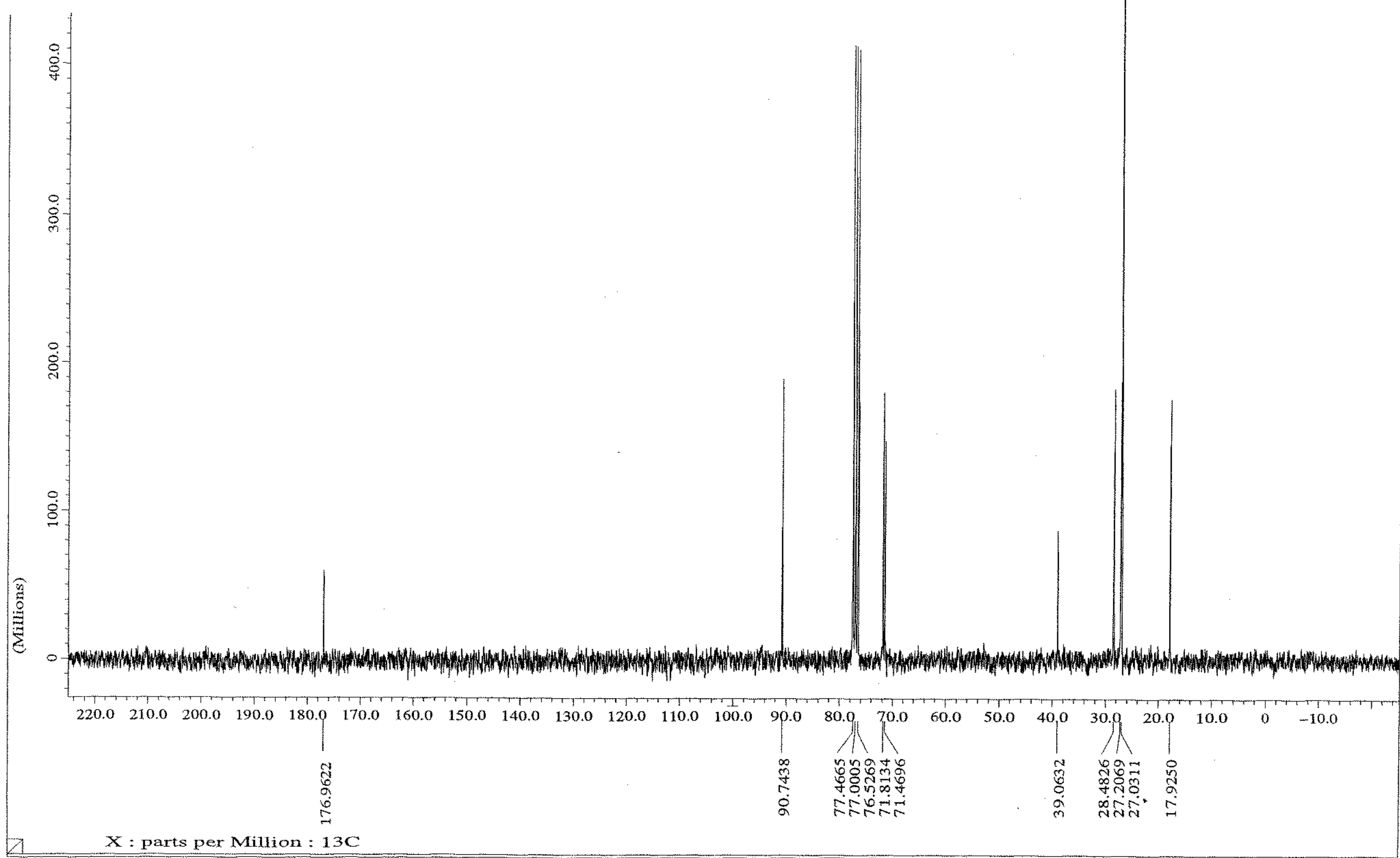


$\left((2 R, 5 S, 6 R)-4-\left(\left(2 ' S, 6^{\prime} R\right)-5,6\right.\right.$-dihydro-6-methyl-5-0xo-2H-pyran-2-yloxy)-3,4,5,6-tetrahydro-5-hydroxy-6-methyl-2H-

pyran-2-yl pivalate (38).

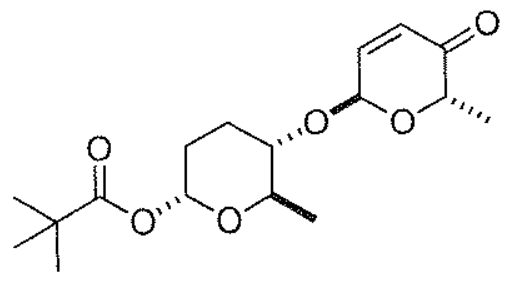

${ }^{1} \mathrm{H} \mathrm{NMR}\left(\mathrm{CDCl}_{3}, 600 \mathrm{MHz}\right)$

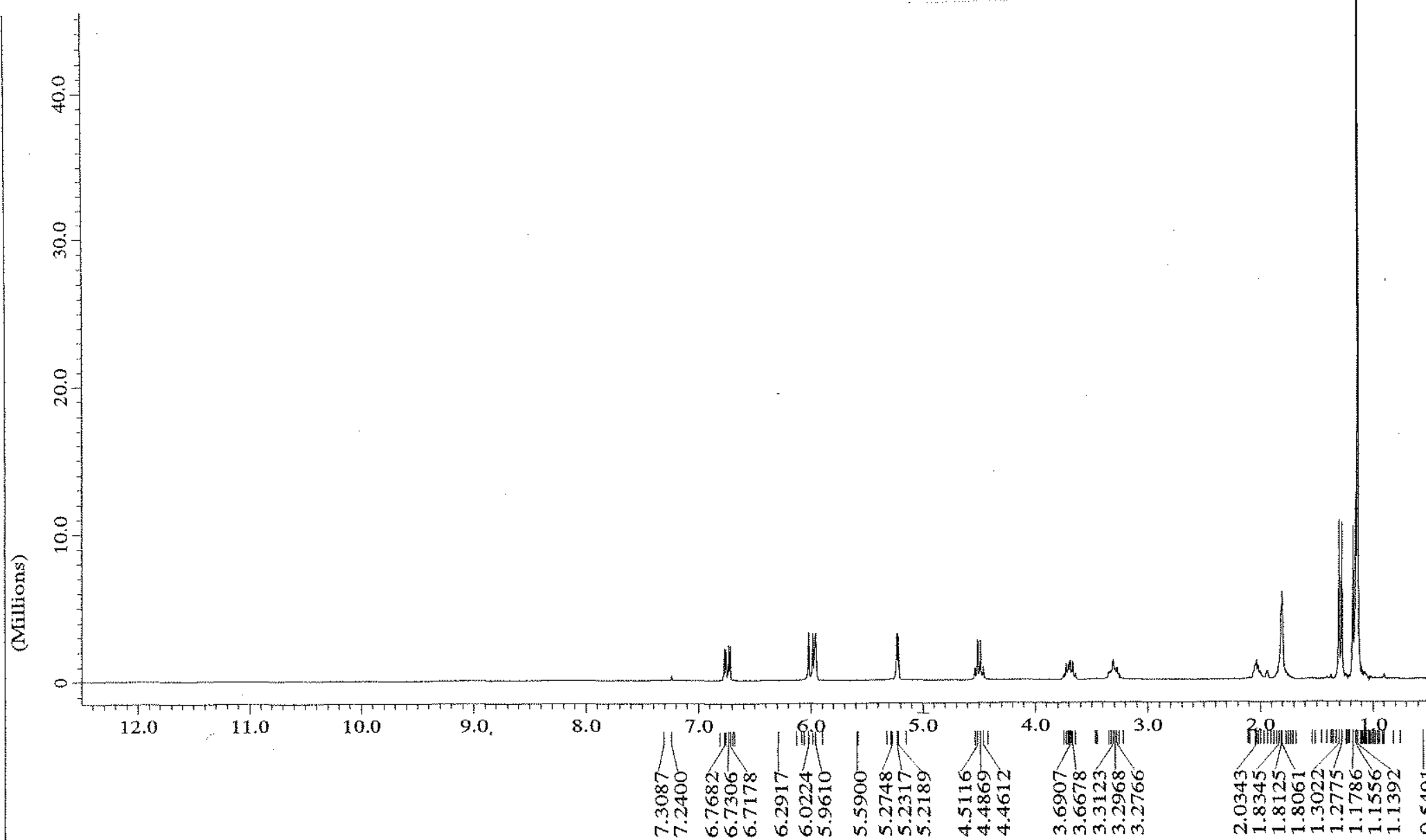


pyran-2-yl pivalate (38).

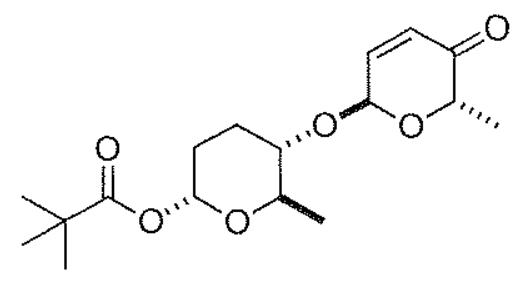

${ }^{13} \mathrm{C} \mathrm{NMR}\left(\mathrm{CDCl}_{3}, 150 \mathrm{MHz}\right)$

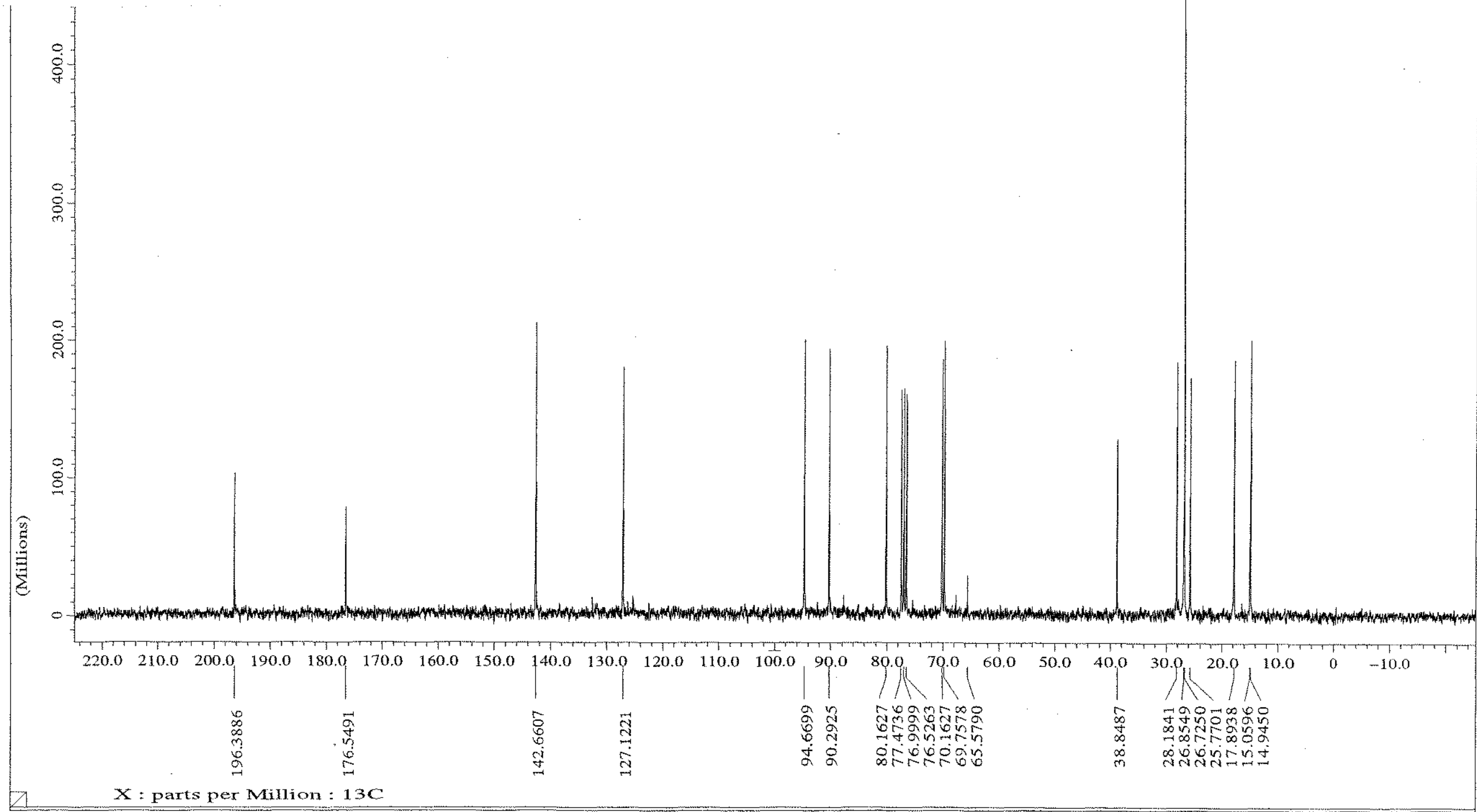


$\left((2 R, 5 S, 6 R)-4-\left(\left(2^{\prime} S, 6^{\prime} R\right)-5,6\right.\right.$-dihydro-5-(4-acetate)-6-methyl-2H-pyran-2-yloxy)-3,4,5,6-tetrahydro-5-hydroxy-6methyl-2H-pyran-2-yl pivalate (39).

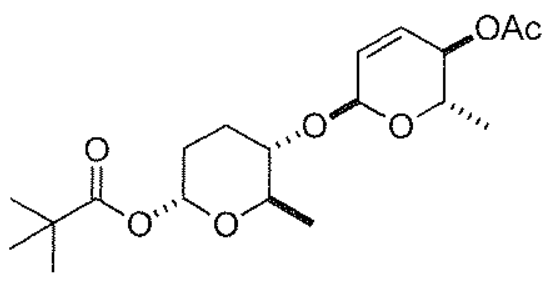

${ }^{1} \mathrm{H} \mathrm{NMR}\left(\mathrm{CDCl}_{3}, 600 \mathrm{MHz}\right)$

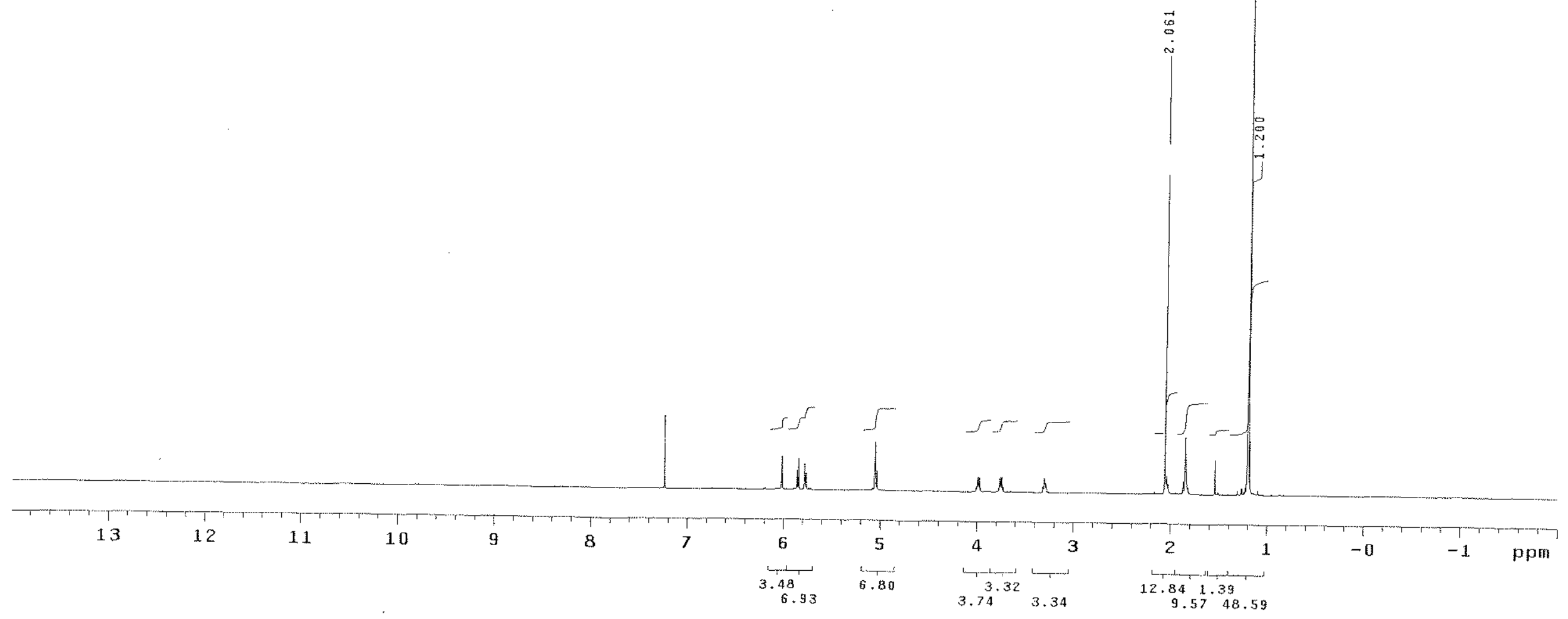


$\left((2 R, 5 S, 6 R)-4-\left(\left(2 ' S, 6^{\prime} R\right)-5,6-d i h y d\right.\right.$ ro-5-(4-acetate)-6-methyl-2H-pyran-2-yloxy)-3,4,5,6-tetrahydro-5-hydroxy-6methyl-2H-pyran-2-yl pivalate (39).

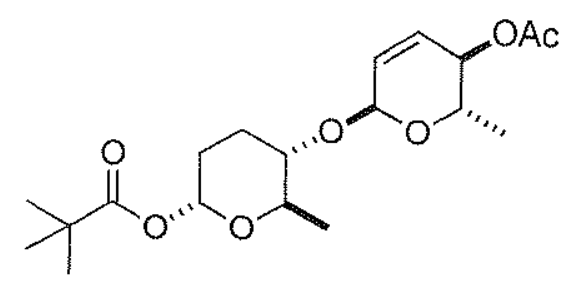

Total time 32 ain, $34 \mathrm{sec}$

\section{${ }^{13} \mathrm{C} \mathrm{NMR}\left(\mathrm{CDCl}_{3}, 150 \mathrm{MHz}\right)$}

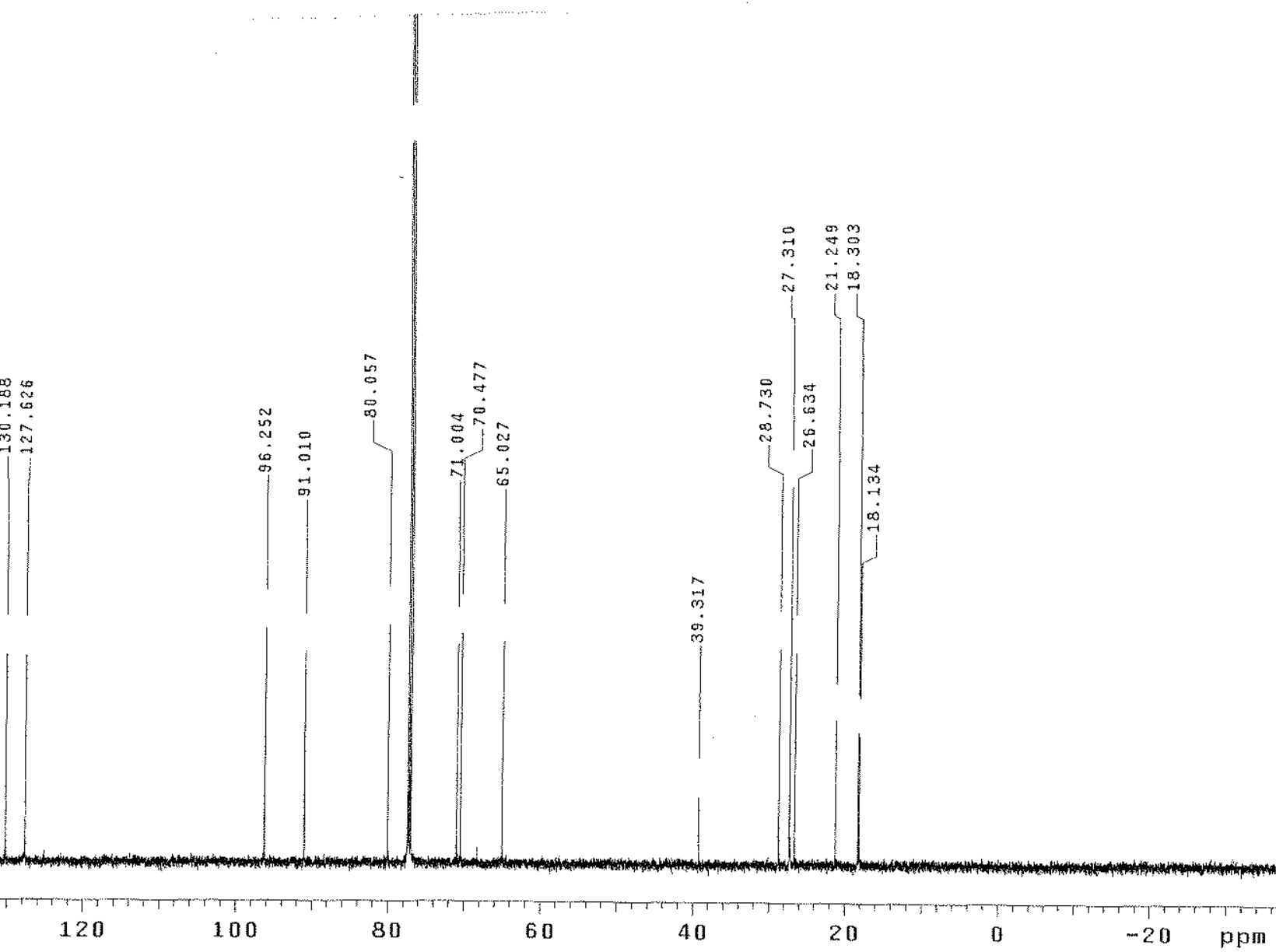


$\beta_{y}, \ldots=$

2-Bromo-8-hydroxy-1,4-dimethoxynaphthalene 33

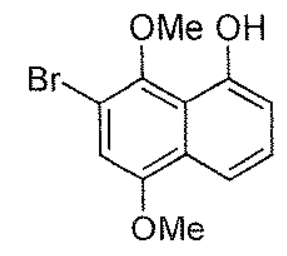

${ }^{1} \mathrm{H} \mathrm{NMR}\left(\mathrm{CDCl}_{3}, 600 \mathrm{MHz}\right)$

HOSERV HA, $399.00 / 40 / 1$ MHZ

DATA PROCESSING

fine broadening $0.2 \mathrm{~Hz}$

FT size 131072
Total time $0 \mathrm{~min}, 5 \mathrm{sec}$

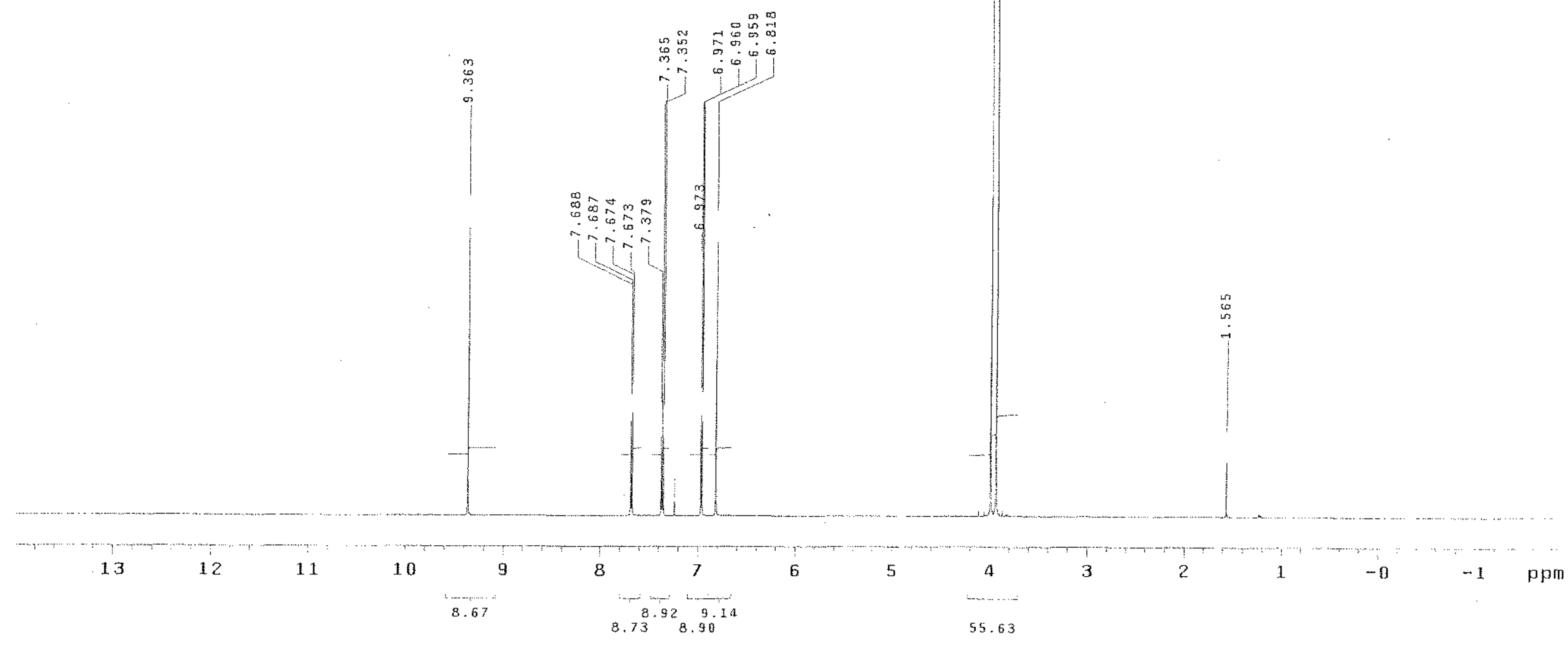




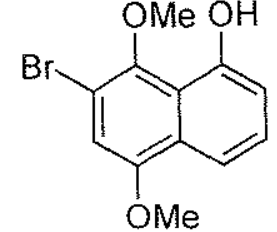

Line broadenting

FT ine broadening $1.0 \mathrm{~Hz}$

Total time $32 \mathrm{~min}, 34 \mathrm{sec}$
${ }^{13} \mathrm{C} \mathrm{NMR}\left(\mathrm{CDCl}_{3}, 150 \mathrm{MHz}\right)$ $\stackrel{2}{2}$

$\hat{n}$

品

$\vec{m}$

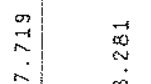

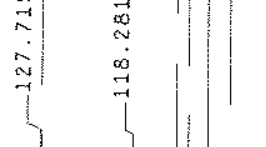

象

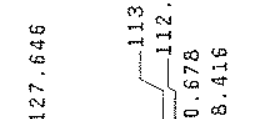

$\stackrel{\infty}{ \pm}$

$\stackrel{+}{+}$

W W.

200

180

160

140

100

80

60 


\section{$-1 m b$}

$(2 R, 3 S, 4 R, 6 R)-6-($ hydroxy $)-2-$ methyl-3-((2S,5S,6S)-6-methyl-5-((2R,6S)-6-methyl-5-oxo-5,6-dihydro-2H-pyran-2-

yloxy)-tetrahydro-2H-pyran-2-yloxy)-tetrahydro-2H-pyran-4-yl acetate (43):

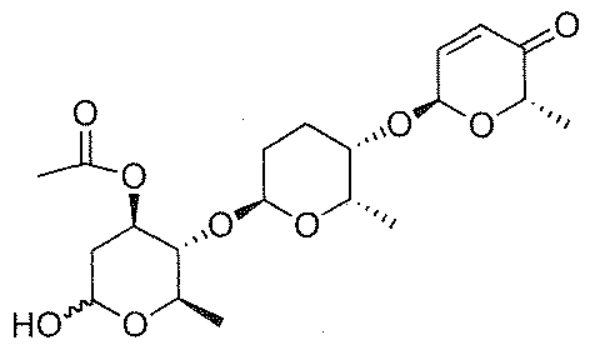

${ }^{1} \mathrm{H}$ NMR (CDCl, $\left.600 \mathrm{MHz}\right)$

As an equilibrating mixture of stereo- and regio-isomers:

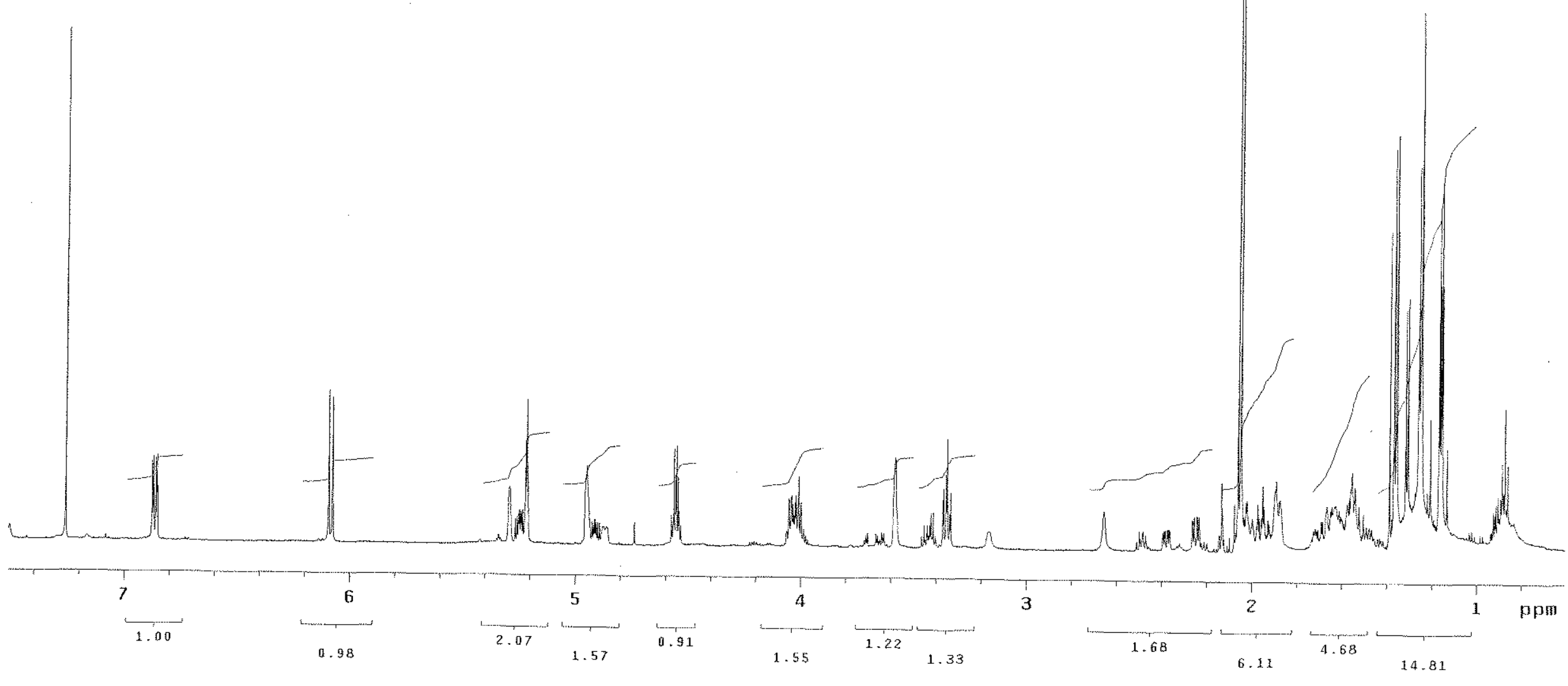


$(2 R, 3 S, 4 R, 6 R)-6-($ bydroxy)-2-methyl-3-((2S,5S,6S)-6-methyl-5-((2R,6S)-6-methyl-5-oxo-5,6-dihydro-2H-pyran-2yloxy)-tetrahydro-2 $H$-pyran-2-yioxy)-tetrahydro-2 $H$-pyran-4-yl acetate (43);

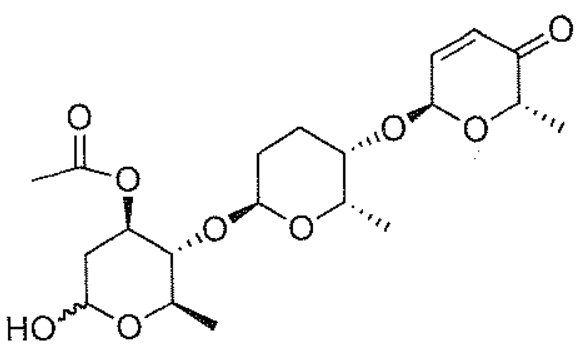

${ }^{13} \mathrm{C} \mathrm{NMR}\left(\mathrm{CDCl}_{3}, 150 \mathrm{MHz}\right)$

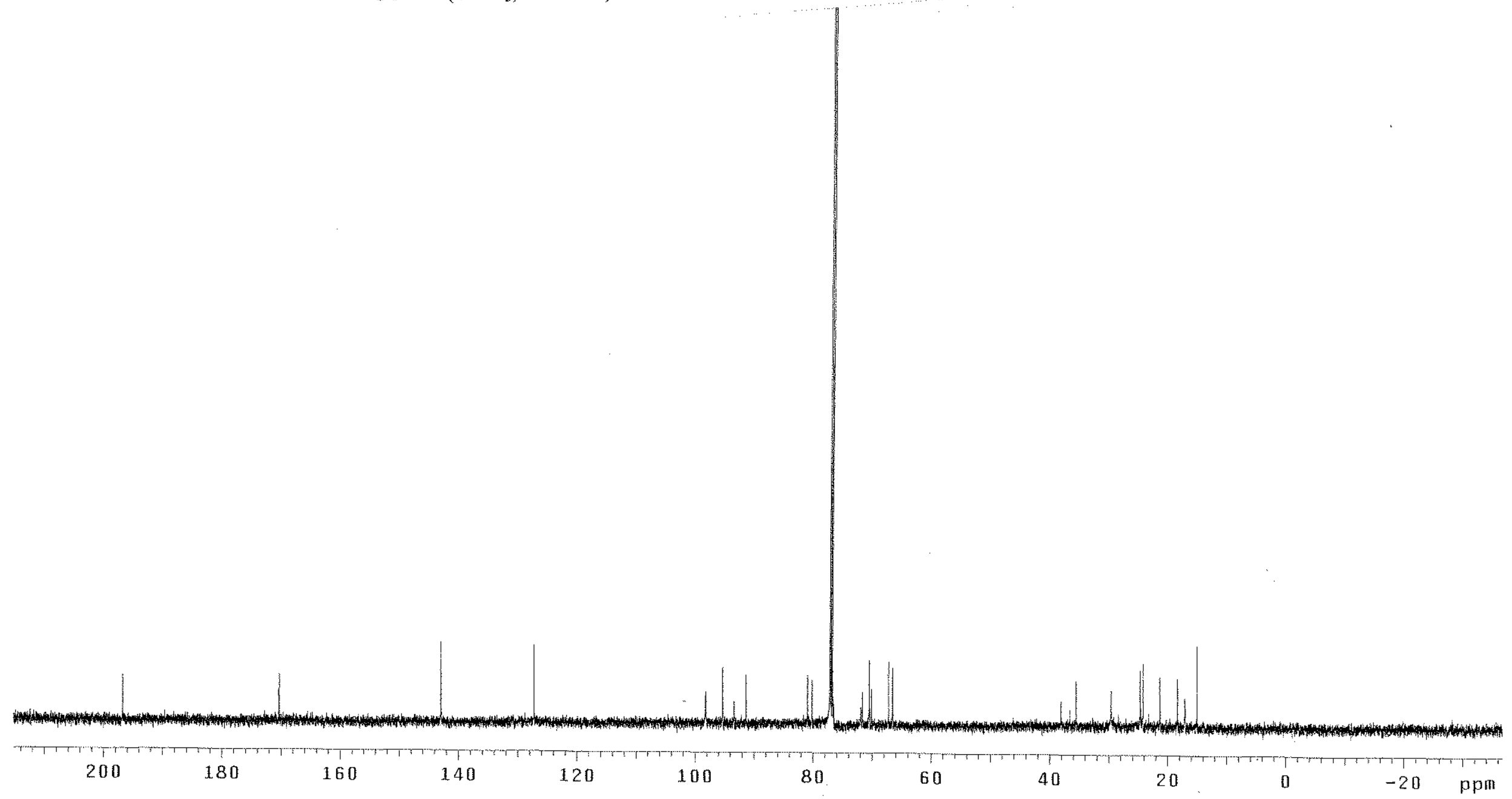


$(2 R, 3 S, 4 R, 6 R)-6$-(7-bromo-5,8-dimethoxynaphthalenyloxy)-2-methyl-3-((2S,5S,6S)-6-methyl-5-((2R,6S)-6-methyl-5oxo-5,6-dihydro-2H-pyran-2-yloxy)-tetrahydro-2 $H$-pyran-2-yloxy)-tetrahydro-2 $H$-pyran-4-yl acetate $(44 \alpha)$ :

$(2 R, 3 S, 4 R, 6 S)-6-(7-b r o m o-5,8-d i m e t h o x y n a p h t h a l e n y l o x y)-2-m e t h y l-3-((2 S, 5 S, 6 S)-6-m e t h y l-5-((2 R, 6 S)-6-m e t h y l-5-$ oxo-5,6-dibydro-2 $H$-pyran-2-yloxy)-tetrahydro-2 $H$-pyran-2-yloxy)-tetrahydro-2H-pyran-4-yl acetate (44 $\beta)$ :

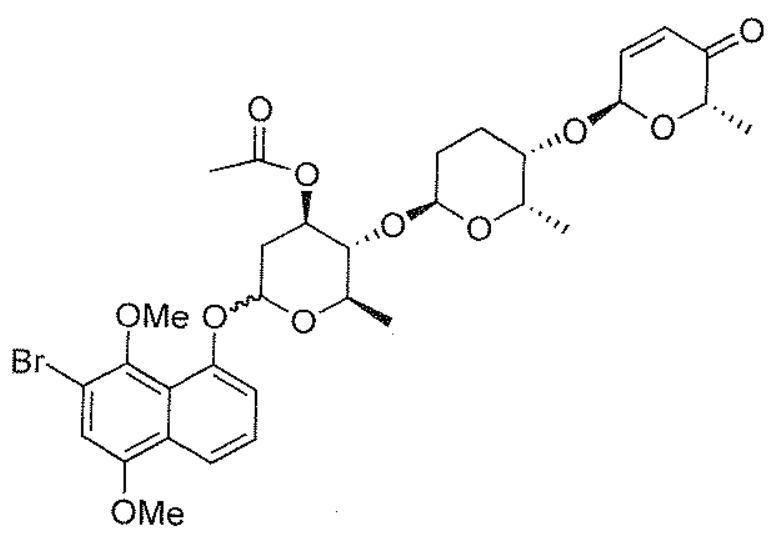

As an inseparable mix ture of stereo-isomers:

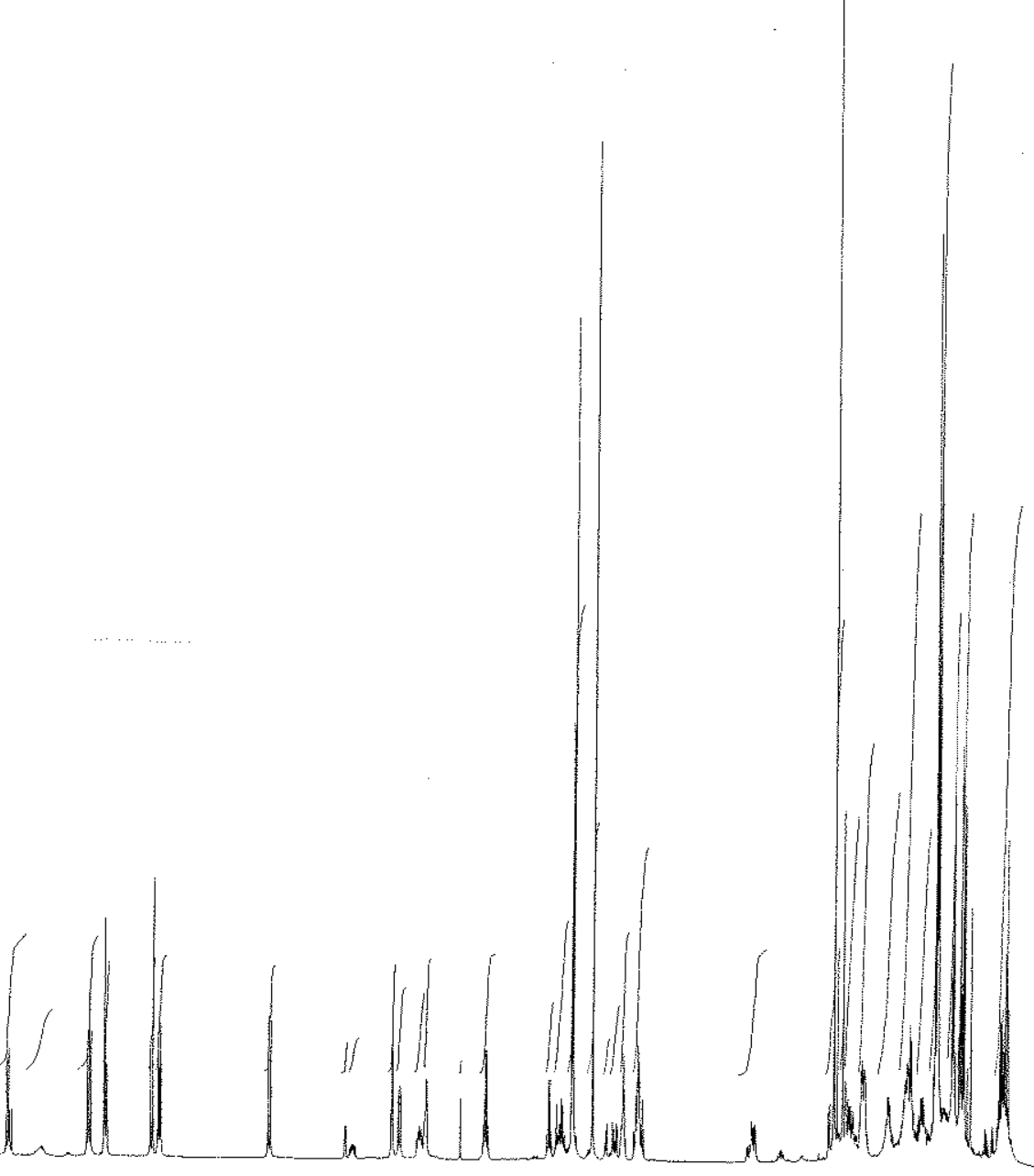


$(2 R, 3 S, 4 R, 6 R)-6-(7-b r o m o-5,8$-dimethoxynaphthalenyloxy)-2-methyl-3-((2S,5S,6S)-6-methyl-5-((2R,6S)-6-methyl-5oxo-5,6-dihydro-2H-pyran-2-yloxy)-tetrahydro-2H-pyran-2-yloxy)-tetrahydro- $2 H$-pyran-4-yl acetate (44a):

$(2 R, 3 S, 4 R, 6 S)-6-(7-b r o m o-5,8-d i m e t h o x y n a p h t h a l e n y l o x y)-2-m e t h y l-3-((2 S, 5 S, 6 S)-6-m e t h y l-5-((2 R, 6 S)-6-m e t h y l-5-$

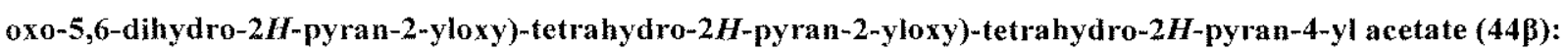

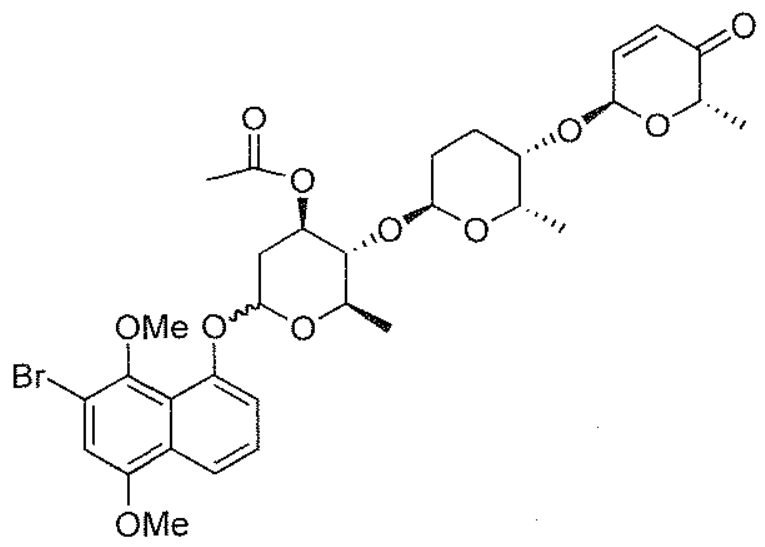

